\title{
Genome Mining-Based Discovery of Fungal Macrolides Modified by glycosylphosphatidylinositol (GPI)-Ethanolamine Phosphate Transferase Homologues
}

Yohei Morishita,${ }^{a}$ Yu Aoki,${ }^{a}$ Mei Ito, ${ }^{b}$ Daisuke Hagiwara,${ }^{c, d}$ Kensho Torimaru, ${ }^{e}$ Daichi Morita, ${ }^{e}$ Teruo Kuroda, ${ }^{e}$ Hanako Fukano, ${ }^{f}$ Yoshihiko Hoshino, ${ }^{f}$ Masato Suzuki, ${ }^{g}$ Tohru Taniguchi, ${ }^{h}$ Keiji Mori, ${ }^{i}$ Teigo $\mathrm{Asai}^{a, j *}$

${ }^{a}$ Department of Life Sciences, Graduate School of Arts and Sciences, The University of Tokyo, 3-8-1 Komaba, Meguro-ku, Tokyo 153-8902, Japan, ${ }^{b}$ Tokyo University of Science, 6-3-1 Niijuku, Katsushika-ku, Tokyo 125-8585, Japan, ${ }^{c}$ Department of Life and Environmental Sciences, University of Tsukuba, 1-1-1 Tennodai, Tsukuba, Ibaraki 305-8577, Japan, ${ }^{d}$ Microbiology Research Center for Sustainability (MiCS), University of Tsukuba, 1-1-1 Tennodai, Tsukuba, Ibaraki 305-8577, Japan, ${ }^{e}$ Department of Microbiology, Institute of Biomedical and Health Sciences, Hiroshima University, 1-2-3 Kasumi, Minami-ku, Hiroshima 734-8553, Japan, ${ }^{f}$ Department of Mycobacteriology, Leprosy Research Center, National Institute of Infectious Diseases, 4-2-1 Aobacho, Higashimurayama-shi, Tokyo 189-0002, Japan, ${ }^{g}$ Antimicrobial Resistance Research Center, National Institute of Infectious Diseases, 4-2-1 Aobacho, HigashiMurayama-shi, Tokyo 189-0002, Japan, ${ }^{\text {h}}$ Frontier Research Center for Advanced Material and Life Science, Faculty of Advanced Life Science, Hokkaido University, Kita 21 Nishi 11, Sapporo 001-0021, Japan, ${ }^{i}$ Department of Applied Chemistry, Graduate School of Engineering, Tokyo University of Agriculture and Technology, 2-24-16 Nakacho, Koganei, Tokyo 184-8588, Japan, ${ }^{j}$ Graduate School of Pharmaceutical Sciences, Tohoku University, 6-3 Aza-Aoba, Aramaki, Aoba-ku, Sendai 980-8578, Japan

\section{Table of contents}

SI-2: $\quad$ Experimental equipment, Fungal material, Heterologous host strains, Culture medium

SI-3: $\quad$ Construction of the $\mathrm{akml} / \mathrm{ciml}$ cluster expression system, Cultivation of the transformants and $A$. kawachii and C. incanum

SI-4: Antimicrobial assay, Antifungal susceptibility test

SI-5: $\quad$ Table S1. akml cluster, Table S2. ciml cluster, Table S3. Bioactivities of 1-8

SI-6: $\quad$ Table S4. Primers used for cloning, Table S5. Expression plasmid vector, Table S6. A. oryzae transformants constructed in this study

SI-7: $\quad$ Figure S1. Analysis of biosynthetic gene clusters coding a HR-PKS and a GPI-EPT homologue.

SI-8: $\quad$ Figure S2. Analysis of mycelial extracts of A. kawachii and C. incanum, Figure S3. Phylogenetic analysis of GPI-EPT homologues

SI-9: $\quad$ Isolation and 2D structure determination of AKMLs A-D (1-4).

SI-13: Table S7. NMR data for AKMLs A-D (1-4)

SI-14: Determination of the absolute configurations of AKMLs A-D (1-4) Figure S4. Determination of absolute configurations of AKMLs A-D.

SI-16: Table S8. NMR data for $\mathbf{1 0}$

SI-19: Isolation and 2D structure determination of CIMLs A-D (5-8)

SI-23: Table S9. NMR data for CIMLs A-D (5-8)

SI-24: Determination of the absolute configurations of CIMLs A-D (5-8)

Figure S5. Determination of absolute configurations of CIMLs A-D.

SI-25: Table S10. NMR data for $\mathbf{1 7}$

SI-27: Determination of the configuration of the epoxide moiety by GIAO NMR Calculations Table S11. GIAO NMR Calculations of AKML B (2) and epi-AKML B (20)

SI-28: Table S12. GIAO NMR Calculations of CIML B (6) and epi-CIML B (21)

SI-30: $\quad$ NMR spectra of 1-11, 13-15 and 17-19 


\section{Experimental equipment}

Analytical TLC were performed on silica gel 60 F254 (Merck) and RP-18 F254 (Merck). Column chromatography was carried out on silica gel 60 (70-230 and 40-50 mesh). The NMR spectra were recorded on a Bruker AVANCE III 500 spectrometer $\left({ }^{1} \mathrm{H}\right.$ NMR, $\left.500 \mathrm{MHz} ;{ }^{13} \mathrm{C} \mathrm{NMR}, 125 \mathrm{MHz}\right)$ or a JEOL ECA-600 ( ${ }^{1} \mathrm{H}$ NMR, $600 \mathrm{MHz} ;{ }^{13} \mathrm{C}$ NMR, $\left.150 \mathrm{MHz}\right)$. Chemical shifts for ${ }^{1} \mathrm{H}$ and ${ }^{13} \mathrm{C}$ NMR are given in parts per million $(\delta)$ relative to tetramethylsilane $\left(\delta_{\mathrm{H}} 0.00\right)$ and residual solvent signals $\left(\delta_{\mathrm{C}} 77.0\right)$ for $\mathrm{CDCl}_{3},\left(\delta_{\mathrm{H}} 3.30, \delta_{\mathrm{C}} 49.0\right)$ for $\mathrm{CD}_{3} \mathrm{OD}$ and $\left(\delta_{\mathrm{H}} 7.16, \delta_{\mathrm{C}} 128.4\right)$ for $\mathrm{C}_{6} \mathrm{D}_{6}$ as internal standards. Mass spectra were measured on Exactive Orbitrap Mass Spectrometer (Thermo Fischer Scientific). IR was measured on a JASCO FVS-6000 spectrometer. UV spectra were recorded on a JASCO-V-730 spectrophotometer. HPLC analysis was performed on a JASCO AS-1555-10 Intelligent Sampler, a JASCO PU-4180 RHPLC Pump, a JASCO MD-4017 Photo Diode Array Detector (JASCO), which equipped with a COSMOSIL Packed Column 5C18-MS-II $(\phi 4.6 \mathrm{~mm} \times 150 \mathrm{~mm})$ (Nacalai tesque).

\section{Fungal material}

Aspergillus kawachii IFO 4308 and Colletotrichum incanum MAFF 238704 were obtained from Biological Resource Center, NITE (NBRC) and Ministry of Agriculture, Forestry Fisheries (MAFF) respectively. Each fungus was cultured in a PDB liquid medium for 3 days and the cultured mycelium was ground to a fine powder in liquid $\mathrm{N}_{2}$. To the mycelial powder in $1.5 \mathrm{~mL}$ tube, $100 \mu \mathrm{L}$ TE buffer and lysis solution (SDS 1g, $2.5 \mathrm{~mL}$ Tris-HCl buffer (1 M), EDTA•2Na•2 $\mathrm{H}_{2} \mathrm{O} 186 \mathrm{mg}, \mathrm{NaCl} 292 \mathrm{mg}, 50 \mathrm{~mL} \mathrm{mQ}$ ) were added, gently inverted and incubated $5 \mathrm{~min}$ on ice. After centrifugation at $15,000 \mathrm{rpm}, 4^{\circ} \mathrm{C}$, for 20 min, $100 \mu \mathrm{L}$ of the supernatants were transferred to a new $1.5 \mathrm{~mL}$ tube, followed by phenol extraction using Phenol: Chloroform: Isoamyl Alcohol 25:24:1 (pH 5.2, Nacalai tesque) and ethanol precipitation. After centrifugation again, TE buffer were added to the pellet of DNA. The DNA solutions of $A$. kawachii and $C$. incanum were used as a template for cloning of $a \mathrm{kmlA}-\mathrm{D}$ and $\operatorname{ciml} A-D$ respectively.

\section{Heterologous host strains}

Aspergillus oryzae NSAR1 (niaD $\left.{ }^{-}, s C^{-}, \triangle \arg B, a d e A^{-}\right){ }^{\mathrm{S} 1}$ was used as the host for fungal expression. Escherichia coli Dh5 $\alpha$ (TAKARA) was used for the cloning of akmlA-D and cimlA-D.

\section{Culture medium}

\section{- Culture medium for A. kawachii IFO 4308 and C. incanum MAFF 238704}

- PDB (agar) medium: Potato-Dextrose Broth (DIFCO) $7.2 \mathrm{~g}$ (and agarose (Nacalai tesque) $4.5 \mathrm{~g}$ ) in $300 \mathrm{~mL}$ distilled water.

$\checkmark$ CPS medium (0.015\% adenine): Czapek-Dox Broth (Difco) 1.05 (2.63) g, peptone* 0.3 (0.75) g, Soluble Starch (Nacalai tesque) 0.6 (1.5) g, Maltose Monohydrate (Nacalai tesque) 0.3 (0.75) g and adenine 9 (22.5) $\mathrm{mg}$ in 60 (150) $\mathrm{mL}$ distilled water. *peptone: mixture of $0.2(0.5) \mathrm{g}$ of soy peptone, casein peptone and meat peptone (Nacalai tesque).

- MYG medium: Bacto Peptone (DIFCO) 0.06 g, Bacto Malt Extract (DIFCO) 1.2 g, D-(+)glucose (Nacalai tesque) in $60 \mathrm{~mL}$ distilled water.

\section{- Culture medium for A. oryzae NSAR1}

$\checkmark$ PDB agar medium (adenine 0.05\%, arginine 0.1\%): Potato-Dextrose Broth (DIFCO) $7.2 \mathrm{~g}$ and agarose (Nacalai tesque) $4.5 \mathrm{~g}$, adenine (TCI) $0.15 \mathrm{~g}$, L-arginine (Wako) were suspended in $300 \mathrm{~mL}$ distilled water.

\section{- Culture medium for A. oryzae transformants}

- CD agar medium ( $\mathrm{NaCl} 0.8 \mathrm{M}, 0.01 \%$ adenine, 0.15\% L-methionine): Czapek-Dox Broth (Difco) $10.5 \mathrm{~g}, \mathrm{NaCl}$ (Nacalai tesque) $14 \mathrm{~g}$, agarose (Nacalai tesque) $4.5 \mathrm{~g}$, adenine $30 \mathrm{mg}$ and L-methionine 450 $\mathrm{mg}$ (Nacalai tesque) in $300 \mathrm{~mL}$ distilled water.

CPS medium (0.015\% adenine): described above. 


\section{- Culture medium for E. coli $\mathrm{Dh} 5 \alpha$}

Luria-Bertani (agar) medium: LB Broth, Miller (Nacalai tesque) $5.0 \mathrm{~g}$, (and agarose (Nacalai tesque) $3.0 \mathrm{~g}$ in $200 \mathrm{~mL}$ distilled water. After autoclaved and cooled at room temperature, sterilized ampicillin solutions (final cont. $100 \mu \mathrm{g} / \mathrm{mL}$ ) were added.

\section{Construction of the akm cluster expression system}

The apmlA-D were amplified by PrimeSTAR ${ }^{\circledR}$ MAX DNA Polymerase (TAKARA) with primers in Table S4. E. coli DH5 $\alpha$ were used for cloning, following standard recombinant DNA techniques. Fungal expression plasmid pUARA2 and pUAdeA2 possessing the $\alpha$-amylase promoter (amyB) of $A$. oryzae and auxotrophic marker $\arg B$ and $a d e A$ of $A$. nidulans respectively were used. The akmlA was divided into two equal-sized fragments; each fragment was amplified with the primers $a k m l A \_I F p U K p n I-F W$ and $a k m l A_{-} \mathrm{R} 1$, or $a k m l A_{-} \mathrm{F} 1$ and $a k m l A_{-} \mathrm{IFpUKpnI-RV}$. The $a k m l B$ gene was amplified with the primers $a k m l B \_I F p U N o t I-F W$ and $a k m l B \_I F p U N o t I-R V$. The akmlC gene was amplified with the primers $a k m l C_{-}$IFpUKpnI-FW and $a k m l C_{-}$IFpUKpnI-RV. The $a k m l D$ gene was amplified with the primers akmlD_IFpUNotI-FW and $a k m l D \_$IFpUNotI-RV. A genomic DNA of $A$. kawachii IFO 4308 was used as a template. The PCR products were purified.

The resultant fragment $a k m l A$ and $a k m l B$ were subcloned into pUARA2 which had been digested with Asp718 and NotI to yield pUARA2-akmlAB. The $a \mathrm{kmlC}$ and/or $a \mathrm{kmlD}$ was subcloned into pUAdeA2 which had been digested with Asp718 and/or NotI to yield pUAdeA2-akmlC, akmlD, akmlCD.

$A$. oryzae NSAR1 was transformed with pUARA2-akmlAB to construct AO-akmlAB. The transformant AO-akmlAB was transformed with pUAdeA2-akmlCD, $C, D$ to construct AO-akmlABCD, $A B C, A B D$.

\section{Construction of the ciml cluster expression system}

The cimlA was divided into two equal-sized fragments; each fragment was amplified with the primers cimlA_IFpUKpnI-FW and cimlA_R1, or cimlA_F1 and cimlA_IFpUKpnI-RV. The cimlB gene was amplified with the primers $c i m l B \_$IFpUNotI-FW and $c i m l B \_I F p U N o t I-R V$. The $c i m l C$ gene was amplified with the primers $c i m l C \_$IFpUKpnI-FW and cimlC_IFpUKpnI-RV. The cimlD gene was amplified with the primers cimlD_IFpUNotI-FW and cimlD_IFpUNotI-RV. A genomic DNA of $C$. incanum MAFF 238704 was used as a template. The PCR products were purified.

The resultant fragment $\operatorname{ciml} A$ and $\operatorname{cimlB}$ were subcloned into pUARA2 which had been digested with Asp718 and NotI to yield pUARA2-cimlAB. The $\operatorname{cimlC}$ and/or $\operatorname{cimlD}$ was subcloned into pUAdeA2 which had been digested with Asp718 and/or NotI to yield pUAdeA2-cimlCD, $C, D$.

$A$. oryzae NSAR1 was transformed with pUARA2-cimlAB to construct AO-cimlAB. The transformant AO-cimlAB was transformed with pUAdeA2-cimlCD, $C, D$ to construct AO-cimlABCD, $A B C, A B D$.

\section{Cultivation of the transformants, $A$. kawachii and C. incanum and HPLC analysis}

The transformants $\left(\right.$ A. kawachii/C. incanum) were cultivated on a selection agar plate at $30^{\circ} \mathrm{C}$ and its mycelia was inoculated in CPS medium (and PDB, MYG medium) and incubated at $30^{\circ} \mathrm{C}$ for 5 days. The cultured mycelia were harvested and freeze-dried. The $40 \mathrm{mg}$ of the crushed mycelia was extracted with $1 \mathrm{~mL} \mathrm{MeOH}$ for $30 \mathrm{~min}$. After centrifuged at 13,500 rpm for $15 \mathrm{~min}, 500 \mu \mathrm{L}$ was transferred to a new tube and concentrated under reduced pressure to obtain $\mathrm{MeOH}$ extract. The extract was resuspended with 100 (200) $\mu \mathrm{L} \mathrm{MeOH}$, centrifuged again, and $10 \mu \mathrm{L}$ was injected into HPLC. Flow rate; $1 \mathrm{~mL} / \mathrm{min}$, Solvent gradient system: acetonitrile and water with $0.01 \%$ TFA (0-2 $\min : 20: 80,2-12 \mathrm{~min}: 20: 80$ to $100: 0,12-$ 24 min: 100:0). Absorbance was monitored at $210 \mathrm{~nm}$. 


\section{Antimicrobial assay}

Mycolicibacterium smegmatis JCM5855 and Mycobacteroides abscessus subsp. abscessus JCM13569 were subjected to drug susceptibility testing. The assays were conducted in accordance with standardized micro dilution methods. Inoculated micro dilution plates of M. smegmatis and M. abscessus subsp. abscessus were incubated at $30^{\circ} \mathrm{C}$ for 4 days to allow determination of the MIC for each compound.

Staphylococcus aureus ATCC $29213^{\mathrm{T}}$, Escherichia coli DH5a, Acinetobacter baumannii ATCC 17978, Pseudomonas aeruginosa PAO1 were subjected to drug susceptibility testing. MIC was assessed by the CLSI broth microdilution method. Briefly, MICs were determined in Mueller-Hinton broth (Difco) supplemented with $\mathrm{Ca}^{2+}$ and $\mathrm{Mg}^{2+}$ containing each compound in a two-fold serial dilution series. Approximately 104 cells were inoculated in each well and incubated at $37^{\circ} \mathrm{C}$ for $24 \mathrm{~h}$, and growth was examined visually. The MIC was defined as the lowest concentration that prevented visible growth.

\section{Antifungal susceptibility test}

Minimum inhibitory concentration (MIC) of the compounds against Aspergillus fumigatus IFM 62541, Trichophyton mentagrophytes IFM 62679, Candida albicans IFM 62680, and Cryptococcus neoformans IFM 62681 were determined by broth microdilution method using potato dextrose broth in 96-well plate. For A. fumigatus and T. mentagrophytes, the conidia were collected from 5 to 7 days culture on PDA by scraping with $0.01 \%$ Tween 20 . The conidia suspensions were washed with distilled water and appropriately diluted. In each well, $10^{4}$ conidia were inoculated with the compound at the maximum concentration of $50 \mu \mathrm{M}$. The plates were incubated at $37{ }^{\circ} \mathrm{C}$ (for $\mathrm{A}$. fumigatus) or $30^{\circ} \mathrm{C}$ (for T. mentagrophytes) for $24 \mathrm{~h}$ before judging growth inhibition. For C. albicans and $C$. neoformans, overnight culture in YPD was collected, washed by distilled water, and appropriately diluted. In each well, approximately $10^{4}$ cells were inoculated with the compound at the maximum concentration of $50 \mu \mathrm{M}$. The plates were incubated at $30^{\circ} \mathrm{C}$ for $24 \mathrm{~h}$ before judging growth inhibition. The tests were performed in triplicate. The strains were provided by the National BioResource Project, Japan (http://www.nbrp.jp/). 
Table S1. akml cluster in Aspergillus kawachii IFO 4308.

\begin{tabular}{c|l|l|l|l}
\hline Gene & Accession & Size (bp) & Protein homologue (Accession) & $\begin{array}{l}\text { identity (\%)/ } \\
\text { similarity (\%) }\end{array}$ \\
\hline akmlA & GAA85575 & 7,384 & $\begin{array}{l}\text { HRPKS apmlA [Arthrinium phaeospermum] } \\
\text { (P0CU84) }\end{array}$ & $42 / 58$ \\
ThmlB & GAA85576 & 1,000 & $\begin{array}{l}\text { Thiohydrolase apmlB [Arthrinium phaeospermum }] \\
\text { (P0CU85) }\end{array}$ & $37 / 56$ \\
hypothetical protein [Aspergillus luchuensis CBS 106.47] & GAA85577 & 3,120 & $\begin{array}{l}\text { (OJZ83513) } \\
\text { hypothetical protein [Aspergillus luchuensis CBS 106.47] } \\
\text { (OJZ83514) }\end{array}$ & $96 / 96$ \\
akmlD & BR001646 & 1,624 & $99 / 99$ \\
\hline
\end{tabular}

Table S2. ciml cluster in Colletotrichum incanum MAFF 238704.

\begin{tabular}{|c|c|c|c|c|}
\hline Gene & Accession & Size (bp) & Protein homologue (Accession) & $\begin{array}{l}\text { identity }(\%) / \\
\text { similarity }(\%)\end{array}$ \\
\hline $\operatorname{cimlA}$ & KZL86691 & 7,433 & $\begin{array}{l}\text { HRPKS apmla [Arthrinium phaeospermum] } \\
\text { (P0CU84) }\end{array}$ & $40 / 58$ \\
\hline $\operatorname{cimlB}$ & KZL86692 & 1,028 & $\begin{array}{l}\text { Thiohydrolase apmlB }[\text { Arthrinium phaeospermum }] \\
\text { (P0CU85) }\end{array}$ & $39 / 57$ \\
\hline $\operatorname{cimlC}$ & BR001647 & 3,349 & $\begin{array}{l}\text { hypothetical protein MANI_029600 [Metarhizium anisopliae] } \\
\text { (KFG79131) }\end{array}$ & $41 / 55$ \\
\hline $\operatorname{cimlD}$ & KZL86693 & 1,668 & $\begin{array}{l}\text { Cytochrome P450 family protein [Metarhizium guizhouense ARSEF 977] } \\
\text { (KID81566) }\end{array}$ & $60 / 79$ \\
\hline
\end{tabular}

Table S3. Bioactivities of 1-8.

\begin{tabular}{|c|c|c|c|c|c|c|c|c|c|c|c|}
\hline \multirow[b]{2}{*}{ Cmd. } & \multicolumn{7}{|c|}{ Bacteria $^{a}$} & \multicolumn{2}{|c|}{$\begin{array}{c}\text { Fungi } \\
\text { germination }^{b}\end{array}$} & \multicolumn{2}{|c|}{$\begin{array}{c}\text { Fungi } \\
\text { hyphal growth }\end{array}$} \\
\hline & $E c$ & $A b$ & $\mathrm{~Pa}$ & Ms & Ma & $\mathrm{Sa}$ & $E f$ & $A f$ & $\mathrm{Tm}$ & $A f$ & $\mathrm{Tm}$ \\
\hline 1 & $>125$ & $>125$ & $>62.5$ & 15.6 & $>125$ & - & - & $>50.0$ & $>50.0$ & $>50.0$ & $>50.0$ \\
\hline 2 & $>125$ & $>125$ & $>62.5$ & 31.3 & $>125$ & - & - & $>50.0$ & $>50.0$ & $>50.0$ & $>50.0$ \\
\hline 3 & $>125$ & $>125$ & $>62.5$ & 62.5 & $>125$ & - & - & 50.0 & 25.0 & 25.0 & 12.5 \\
\hline 4 & $>125$ & $>125$ & $>62.5$ & $>125$ & $>125$ & - & - & $>50.0$ & $>50.0$ & $>50.0$ & 50.0 \\
\hline 5 & $>125$ & $>125$ & $>62.5$ & $>125$ & $>125$ & $>50.0$ & $>50.0$ & $>50.0$ & $>50.0$ & $>50.0$ & $>50.0$ \\
\hline 6 & $>125$ & $>125$ & $>62.5$ & 31.3 & $>125$ & 50.0 & 50.0 & $>50.0$ & $>50.0$ & $>50.0$ & 50.0 \\
\hline 7 & $>125$ & $>125$ & $>62.5$ & 62.5 & $>125$ & $>50.0$ & $>50.0$ & 50.0 & 12.5 & $>50.0$ & 6.25 \\
\hline 8 & $>125$ & $>125$ & $>62.5$ & $>125$ & $>125$ & $>50.0$ & $>50.0$ & $>50.0$ & $>50.0$ & $>50.0$ & 50.0 \\
\hline
\end{tabular}

${ }^{a}$ Minimum inhibitory concentration (MIC), ${ }^{b} \mathrm{MIC}_{90},{ }^{c}$ Minimum effective concentration $\left(\mathrm{MEC}_{80}\right), E c$; Escherichia coli DH5a, Ab; Acinetobacter baumannii ATCC 17978, Pa; Pseudomonas aeruginosa PAO1, Ms; Mycolicibacterium smegmatis JCM5855, Ma; Mycobacteroides abscessus subsp. abscessus JCM13569, Sa; Staphylococcus aureus 209P/OM481/OM584, Ef; Enterococcus faecalis NCTC 12201/ATCC 19434/BM4147, Af; Aspergillus fumigatus IFM 62541, Tm; Trichophyton mentagrophytes IFM 62679. 
Table S4. Primers used for cloning in this study.

\begin{tabular}{|c|c|c|}
\hline Primer & DNA sequence $5^{\prime}$ to $3^{\prime}$ & Template strain \\
\hline akmIA_IFpUKpnI-FW & CCGGAATTCGAGCTCGAACATGAACGGTAACATGAATG & \multirow{10}{*}{$\begin{array}{l}\text { Aspergillus kawachi } \\
\text { IFO } 4308\end{array}$} \\
\hline akmIA_IFpUKpnl-RV & ACTACAGATCCCCGGCTACCGCACCAATTTGCCCAG & \\
\hline akmIA-F1 & GGTTGCATCTGGCGATGAAGC & \\
\hline akmIA-R1 & GCTTCATCGCCAGATGCAACC & \\
\hline akm/B_IFpUNotl-FW & TTTGAGCTAGCGGCCAAGATGCCTTCCCACCAAAAC & \\
\hline akm/B_IFpUNotl-RV & GTCACTAGTGCGGCCAAGATCACTTCTTCCCTTCC & \\
\hline akm/C_IFpUKpnI-FW & CCGAATTCGAGCTCGAAGATGATACTACTTTTTTCG & \\
\hline akm/C_IFpUKpnl-RV & ACTACAGATCCCCGGTAATGCAGTCACCCTACACC & \\
\hline akmID_IFpUNotl-FW & TTTGAGCTAGCGGCCGATCATGCCGGCCCCTCATG & \\
\hline akmID_IFpUNotl-RV & GTCACTAGTGCGGCCGCTGTGTTTACAATGAAAGC & \\
\hline cimlA_IFpUKpnl-FW & CCGAATTCGAGCTCGAATATGGTTTCAGTCACAAAGG & \multirow{10}{*}{$\begin{array}{l}\text { Colletotrichum } \\
\text { incanum } \\
\text { MAFF } 238704\end{array}$} \\
\hline cimlA_IFpUKpnl-RV & ACTACAGATCCCCGGAGCTTGACCATTTATGCACC & \\
\hline $\operatorname{cim} I A-\mathrm{F} 1$ & GCTTTGTGAGTGACATCCTG & \\
\hline $\operatorname{cim} I A-\mathrm{R} 1$ & CAGGATGTCACTCACAAAGC & \\
\hline cimlB_IFpUNotl-FW & TTTGAGCTAGCGGCCAAGATGGCGATTTTCGAAGATG & \\
\hline cimlB_IFpUNotl-RV & GTCACTAGTGCGGCCCAGACTTGGTCTACTCTAGG & \\
\hline cim/C_IFpUKpnI-FW & CCGAATTCGAGCTCGAGGATGGTTCAGTTACGCC & \\
\hline cim/C_IFpUKpnl-RV & ACTACAGATCCCCGGTAAGTTGCAGGACTTAGTCC & \\
\hline cim/D_IFpUNotl-FW & TTTGAGCTAGCGGCCACTCATCATGATTGTATCAAG & \\
\hline cimID_IFpUNotl-RV & GTCACTAGTGCGGCCACCGTATCATCCATCACTGG & \\
\hline
\end{tabular}

Table S5. Expression plasmid vector constructed in this study.

\begin{tabular}{cccc}
\hline Plasmid name & Original vector & Gene 1 (Asp718 site) & Gene 1 (Notl site) \\
\hline pUARA2_akmIAB & pUARA2 & $a k m / A$ & $a k m / B$ \\
pUAdeA2_akm/C & pUAdeA2 & $a k m / C$ & \\
pUAdeA2_akmID & pUAdeA2 & & $a k m / D$ \\
pUAdeA2_akm/CD & pUAdeA2 & $a k m / C$ & $a k m / D$ \\
\hline pUARA2_cimlAB & pUARA2 & cimlA & cim/B \\
pUAdeA2_cim/C & pUAdeA2 & cim/C & \\
pUAdeA2_cimlD & pUAdeA2 & & cimlD \\
pUAdeA2_cim/CD & pUAdeA2 & cim/C & cim/D \\
\hline
\end{tabular}

Table S6. A. oryzae transformants constructed in this study.

\begin{tabular}{llll}
\hline Transformant name & Parent strain & Plasmid 1 & Plasmid 2 \\
\hline AO-akmIAB & A. oryzae NSAR1 & pUARA2-akmIAB & \\
AO-akmIABC & AO-akmIAB & pUARA2-akmIAB & pUAdeA2-akm/C \\
AO-akmIABD & AO-akmIAB & pUARA2-akmIAB & pUAdeA2-akmID \\
AO-akmIABCD & AO-akmIAB & pUARA2-akmIAB & pUAdeA2-akmICD \\
\hline AO-cimIAB & $A$. oryzae NSAR1 & pUARA2-cimIAB & \\
AO-cimIABC & AO-cimIAB & pUARA2-cimIAB & pUAdeA2-cim/C \\
AO-cimIABD & AO-cimIAB & pUARA2-cimIAB & pUAdeA2-cimID \\
AO-cimIABCD & AO-cimIAB & pUARA2-cimIAB & pUAdeA2-cim/CD \\
\hline
\end{tabular}


(A)

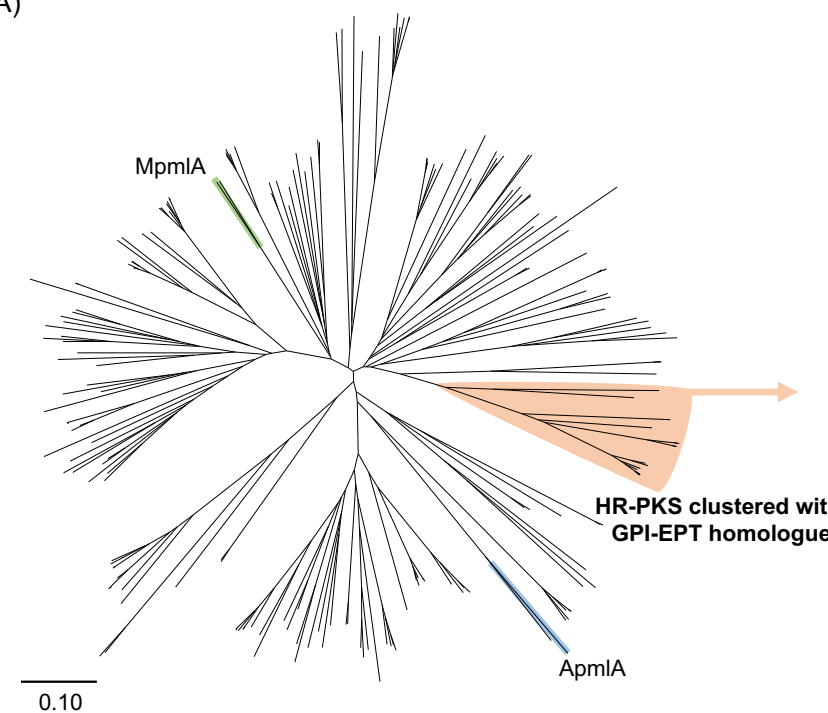

(B)

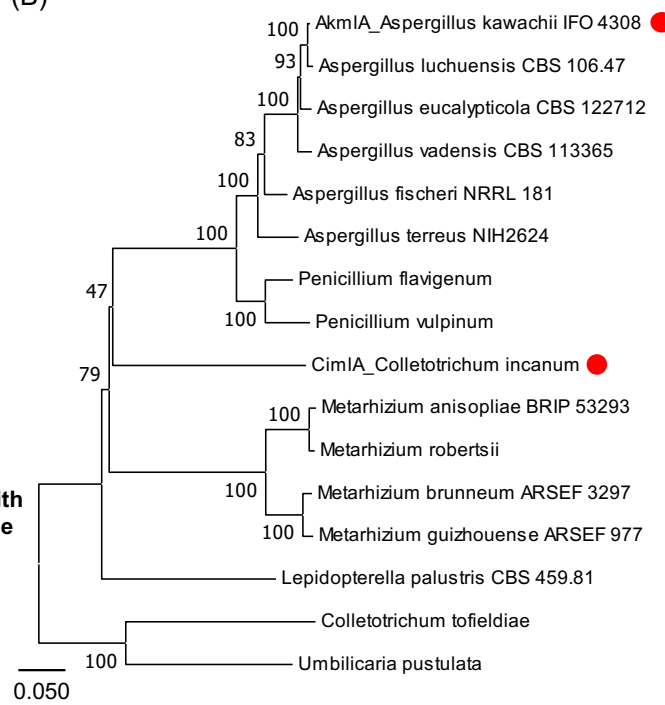

(C)

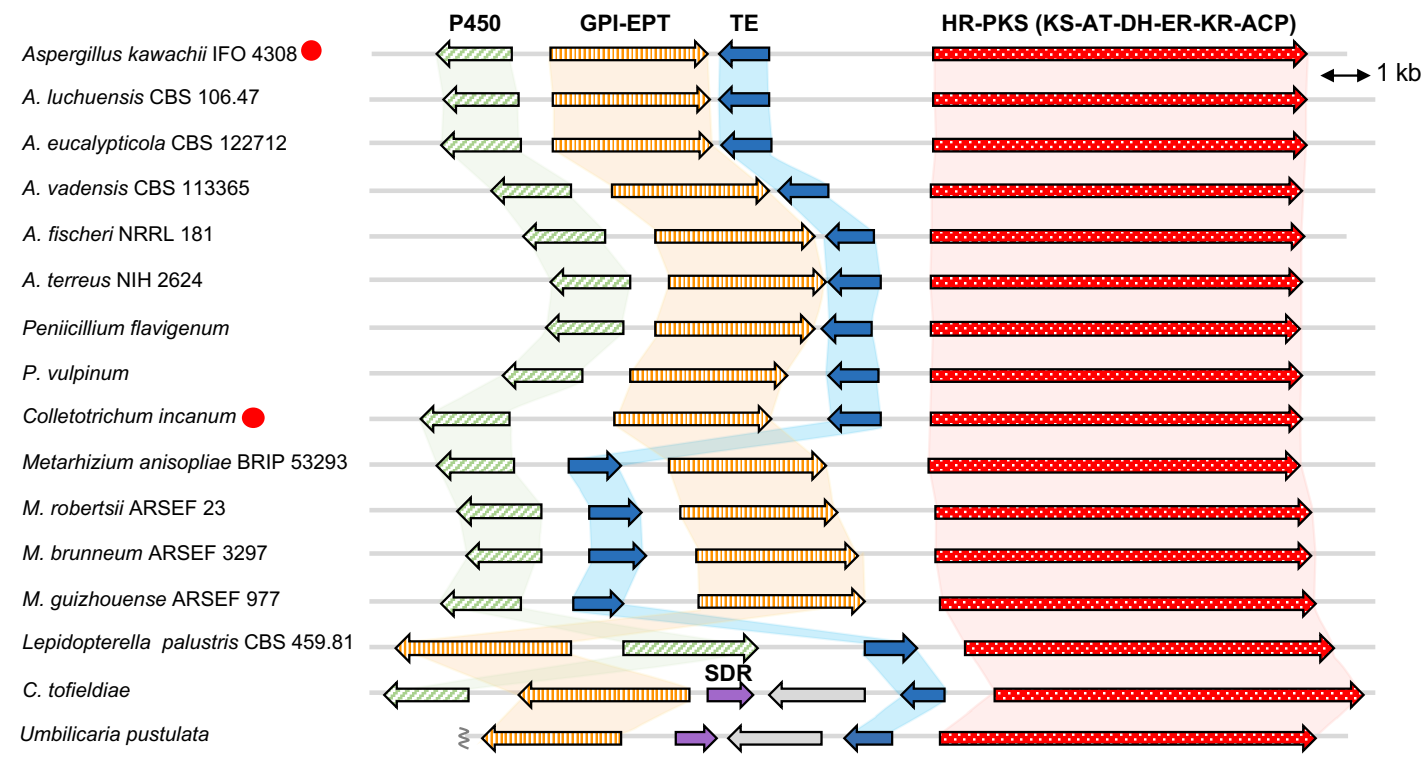

Figure S1. (A) Phylogenetic analysis of fungal HR-PKSs clustered with MhpC-TEs. (B) Expansion of the branch containing HR-PKSs coded with GPI-EPT homologues. The red dots show AkmlA and CimlA described in this study. The amino acid sequence alignment was performed using ClustalW in MEGA7 software, and the phylogenetic tree was inferred by using neighbor-joining method. (C) Organization of putative macrolide biosynthetic gene clusters containing GPI-EPT homologues 
(A)

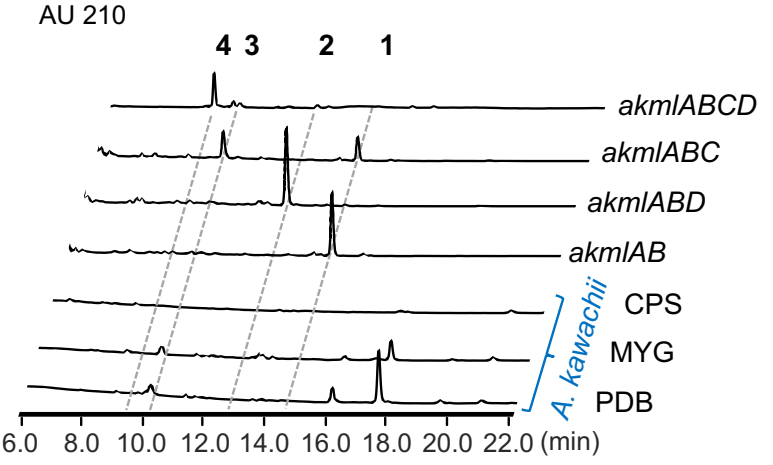

(B)

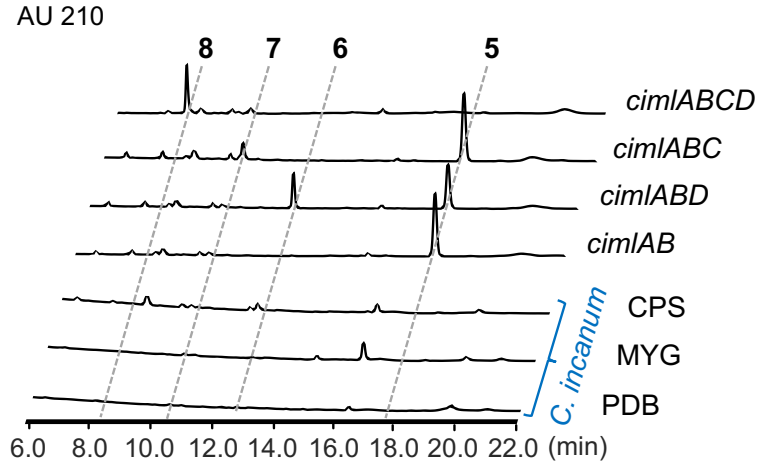

Figure S2. Comparison of HPLC profiles of AO transformants, A. kawachii IFO 4308 and C. incanum MAFF 238704. HPLC profiles of mycelial MeOH extracts of AO transformants in CPS media and (A) $A$. kawachii and (B) C. incanum in some laboratory culture conditions.

Phosphoethanolamine residue
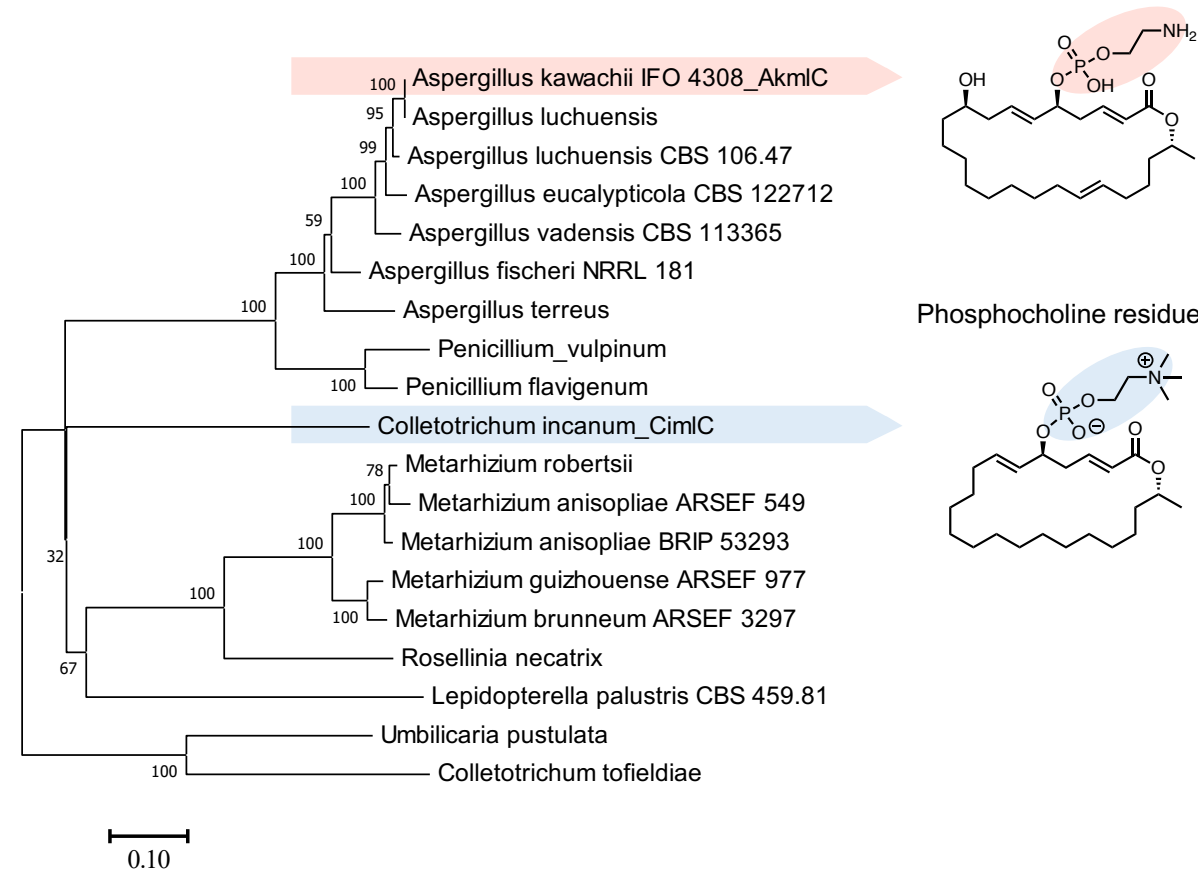

Phosphocholine residue

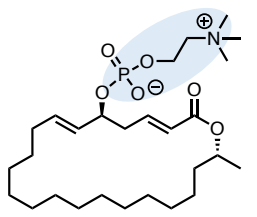

Figure S3. Phylogenetic analysis of GPI-EPT homologues modifying fungal macrolide backbone. The amino acid sequence alignment was performed using ClustalW in MEGA7 software, and the phylogenetic tree was inferred by using neighbor-joining method. 


\section{Isolation of AKML A (1)}

AO-akmlAB was cultivated in CPS medium $(1.8 \mathrm{~L} ; 150 \mathrm{~mL}$ x 12$)$ at $30^{\circ} \mathrm{C}$ for 5 days. The cultured mycelia were harvested, freeze-dried, crushed to powder $(10.4 \mathrm{~g})$ and extracted with $\mathrm{MeOH}$ twice. The $\mathrm{MeOH}$ solution was separated with $n$-hexane, and the $\mathrm{MeOH}$ extracts $(250 \mathrm{mg})$ were obtained. The extracts $(250 \mathrm{mg})$ were subjected to silica gel column chromatography eluted with $\mathrm{CHCl}_{3}-\mathrm{EtOAc}(1 / 1)$, EtOAc to give mixture $\mathbf{1}$. The mixture 1 was separated by flash silica gel column chromatography eluted with $n$-hexane-EtOAc (1/1-1/2) to afford 1 (81 mg).

AKML A (1): Colorless amorphous, Chemical formula $\mathrm{C}_{24} \mathrm{H}_{40} \mathrm{O}_{4}$, HRESIMS: $m / z 415.2819$ [M+Na] ${ }^{+}$ (415.2824 calcd. for $\left.\mathrm{C}_{24} \mathrm{H}_{40} \mathrm{O}_{4} \mathrm{Na}\right),[\alpha]_{\mathrm{D}}^{22}+10.6$ (c 0.64, EtOH); IR (KBr) $v_{\max }\left(\mathrm{cm}^{-1}\right) 3396,2925,2852$, $1716,1711,1656,1462,1442,1313,1271,1173,1035,970$.

\section{D structure determination of AKML A (1)}

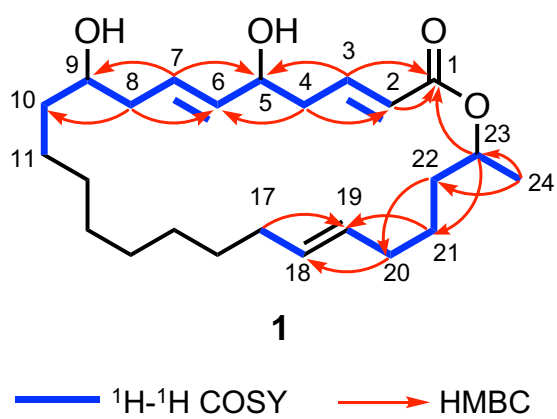

AKML A (1) had a molecular formula of $\mathrm{C}_{24} \mathrm{H}_{40} \mathrm{O}_{4}$, as established by its positive HRESIMS $(\mathrm{m} / \mathrm{z} 415.2819$ $[\mathrm{M}+\mathrm{Na}]^{+}$, calcd 415.2824), and was also supported by ${ }^{1} \mathrm{H}$ and ${ }^{13} \mathrm{C}$ NMR data. IR spectrum indicated absorbance for ester carbonyl $\left(v_{\max } 1716 \mathrm{~cm}^{-1}\right)$ and hydroxy $\left(v_{\max } 3396 \mathrm{~cm}^{-1}\right)$ groups. The direct connectivity between each proton and carbon was confirmed by the ${ }^{1} \mathrm{H},{ }^{13} \mathrm{C}$ and HSQC NMR spectral analysis (Table S7). The consecutive COSY and HMBC correlations indicated the structure from C-2 to $\mathrm{C}-11$ and from $\mathrm{C}-17$ to $\mathrm{C}-24$. The HMBC correlations at $\mathrm{H}-2,-23 / \mathrm{C}-1$ showed the connectivity of $\mathrm{C}-1$ and C-23 through the ester linkage. Based on the chemical formula, the remaining five methylene carbons were set between C-12 and C-16. The $E$ geometries of $\Delta_{2,3}$ and $\Delta_{6,7}$ were characterized by $J$ values of $\mathrm{H}$ $2 / \mathrm{H}-3(J=15.8 \mathrm{~Hz})$ and H-6/H-7 $(J=15.4 \mathrm{~Hz})$, respectively. The geometry of $\Delta_{18,19}$ was determined to be $E$ by the $\delta$ values of the corresponding allylic carbons $\left(\delta_{\mathrm{C}} 31.8(\mathrm{C}-17) \text { and } 32.3(\mathrm{C}-20)\right)^{\mathrm{S} 2}$. The comparison with those of JBIR-19, 20 was also supported the $E$ geometry. ${ }^{\mathrm{S} 3}$ Thus, the planal structure of 1 was determined as shown in Figure 3. 


\section{Isolation of AKML B (2)}

AO-akmlABD was cultivated in CPS medium $(3 \mathrm{~L} ; 150 \mathrm{~mL}$ x 24$)$ at $30^{\circ} \mathrm{C}$ for 5 days. The cultured mycelia were harvested, freeze-dried, crushed to powder $(20 \mathrm{~g})$ and extracted with $\mathrm{MeOH}$ twice. The $\mathrm{MeOH}$ solution was separated with $n$-hexane, and the $\mathrm{MeOH}$ extracts $(450 \mathrm{mg}$ ) were obtained. The extracts $(450 \mathrm{mg})$ were subjected to silica gel column chromatography eluted with $\mathrm{CHCl}_{3}-\mathrm{MeOH}(20 / 1)$ to give mixture $\mathbf{2}(92 \mathrm{mg})$. The mixture $\mathbf{2}(92 \mathrm{mg})$ was separated by flash silica gel column chromatography eluted with $\mathrm{CHCl}_{3}$-EtOAc (1/1-1/3) to give crude $2(79 \mathrm{mg})$. The crude 2 (79 mg) was subjected to flash silica gel column chromatography eluted with $\mathrm{CHCl}_{3}-\mathrm{MeOH}$ (30/1) to afford 2 (60 mg).

AKML B (2): Colorless amorphous, Chemical formula $\mathrm{C}_{24} \mathrm{H}_{40} \mathrm{O}_{6}$, HRESIMS: $m / z 447.2726[\mathrm{M}+\mathrm{Na}]^{+}$ (447.2717 calcd. for $\left.\mathrm{C}_{24} \mathrm{H}_{40} \mathrm{O}_{6} \mathrm{Na}\right),[\alpha]_{\mathrm{D}}^{22}+14.6$ (c 0.41, EtOH); IR (KBr) $v_{\max }\left(\mathrm{cm}^{-1}\right) 3421,2924,2852$, $1717,1715,1654,1458,1261,1209,1175,1112,1063,977,911$.

\section{D structure determination of AKML B (2)}

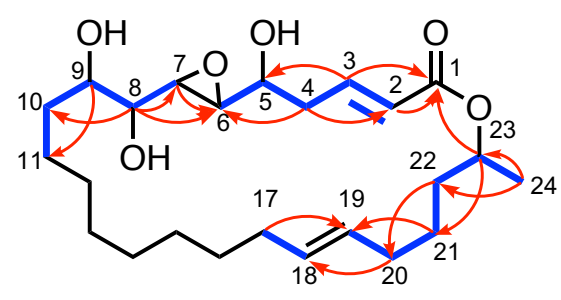

2

$\longrightarrow{ }^{1} \mathrm{H}-{ }^{1} \mathrm{H}$ COSY $\longrightarrow \mathrm{HMBC}$

AKML B (2) had a molecular formula of $\mathrm{C}_{24} \mathrm{H}_{40} \mathrm{O}_{6}$, as indicated by its positive HRESIMS $(\mathrm{m} / \mathrm{z}$ 447.2726 [M+Na] $]^{+}$, calcd 447.2717), implying five degrees of unsaturation. The ${ }^{1} \mathrm{H}$ and ${ }^{13} \mathrm{C}$ NMR spectra of $\mathbf{2}$ shows similar patterns to those of $\mathbf{1}$, except for the existence of characteristic epoxide peaks at $\delta_{\mathrm{H}} 2.93$ (m, H-6), $2.92(\mathrm{~m}, \mathrm{H}-7)$ and $\delta_{\mathrm{C}} 60.8(\mathrm{C}-6), 58.7$ (C-7) instead of olefin signals of 2, and additional oxymethine peaks at $\delta_{\mathrm{H}} 3.09(\mathrm{t}, 6.8, \mathrm{H}-8)$ and $\delta_{\mathrm{C}} 76.9$ (C-8) (Table S7). Based on the chemical formula, the remaining five methylene carbons were set between $\mathrm{C}-12$ and $\mathrm{C}-16$. The relative stereochemistry of the epoxide ring at C-6 and C-7 was determined as trans, as well as 4 (described later) from the point of view of biosynthesis. The geochemistry of the olefin at C-2 was determined as trans from its $J$ values of $\mathrm{H}-2 / \mathrm{H}-3(J=15.6 \mathrm{~Hz})$, similar to that of $\mathbf{1}$. In addition to the biosynthetic relationship with $\mathbf{1}$, the $E$ configuration at $\Delta_{18,19}$ was established by the $\delta$ values of the corresponding allylic carbons $\left(\delta_{\mathrm{C}} 33.0(\mathrm{C}-17)\right.$ and 33.1 (C-20)). From the above and corresponding 2D NMR correlations, we determined the plane structure of 2 (Figure 3, Table S7). 


\section{Isolation of AKML C (3)}

$\mathrm{AO}-a \mathrm{kmlABC}$ was cultivated in CPS medium $(3.2 \mathrm{~L} ; 150 \mathrm{~mL}$ x 21$)$ at $30^{\circ} \mathrm{C}$ for 5 days. The cultured mycelia were harvested, freeze-dried, crushed to powder $(32.4 \mathrm{~g})$ and extracted with $\mathrm{MeOH}$ twice, and the extracts $(4.0 \mathrm{~g})$ were obtained. The $\mathrm{MeOH}$ soluble fraction was subjected to silica gel column chromatography eluted with EtOAc-MeOH (1/1-1/3) to give mixture $3(100 \mathrm{mg})$. The mixture $3(100 \mathrm{mg})$ was separated by reversed-phase column chromatography eluted with MeOH-water (1/4-1/9) to afford 3 $(8.3 \mathrm{mg})$.

AKML C (3): Colorless amorphous, Chemical formula $\mathrm{C}_{26} \mathrm{H}_{46} \mathrm{NO}_{7} \mathrm{P}$, HRESIMS: $\mathrm{m} / z 514.2948$ [M-H] (514.2928 calcd. for $\left.\mathrm{C}_{26} \mathrm{H}_{45} \mathrm{NO}_{7} \mathrm{P}\right),[\alpha]_{\mathrm{D}}{ }^{22}+11.8(\mathrm{c} 0.34, \mathrm{MeOH})$; IR $(\mathrm{KBr}) v_{\max }\left(\mathrm{cm}^{-1}\right) 3391,3293,2926$, $2853,1715,1653,1460,1216,1076,1024,984$.

\section{D structure determination of AKML C (3)}

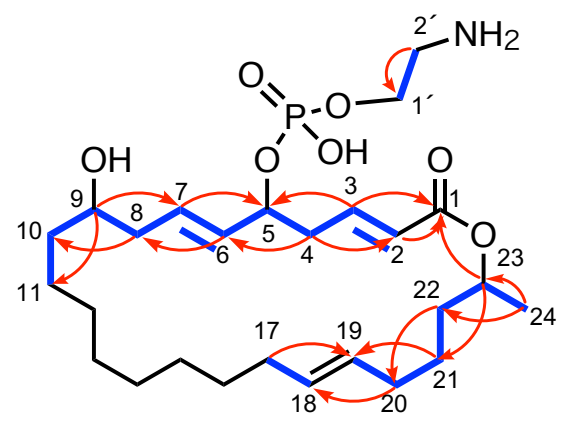

3

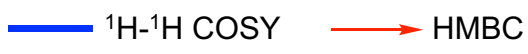

AKML C (3) had a molecular formula of $\mathrm{C}_{26} \mathrm{H}_{46} \mathrm{NO}_{7} \mathrm{P}$, as indicated by its negative HRESIMS $(\mathrm{m} / z$ 514.2948 [M-H] $]^{-}$, calcd 514.2928). The direct connectivity between each proton and carbon was established by the HSQC spectrum (Table S7). Comparing the ${ }^{1} \mathrm{H}$ and ${ }^{13} \mathrm{C}$ NMR spectra, the overall macrolide skeleton of 3 was the same as that of $\mathbf{1}$, except for the presence of an oxymethine at $\delta_{\mathrm{H}} 4.00(\mathrm{~m}$, $\left.\mathrm{H}_{2}-1^{\prime}\right)$ and an aminomethylene at $\delta_{\mathrm{H}} 3.12\left(\mathrm{~m}, \mathrm{H}_{2}-2^{\prime}\right)$ protons. The COSY correlation between the oxymethine and aminomethylene protons showed the presence of an ethanolamine moiety. From the difference of the molecular weights between $\mathbf{1}$ and $\mathbf{3}$, and the putative function of introduced modifying enzyme (ethanolamine phosphate transferase homologue), $\mathbf{3}$ was suggested to have a phosphoethanolamine moiety at C-5 or C-9. The doublet signals of the carbons at C-5 $\left(\delta_{\mathrm{C}} 76.4,{ }^{2} J_{\mathrm{C}-}\right.$ $5, \mathrm{P}=5.5 \mathrm{~Hz})$ and $\mathrm{C}-1^{\prime}\left(\delta_{\mathrm{C}} 60.3,{ }^{2} J_{\mathrm{C}-1^{\prime}, \mathrm{P}}=4.9 \mathrm{~Hz}\right)$, and the adjacent carbons $\left(\mathrm{C}-4: \delta_{\mathrm{C}} 40.0,{ }^{3} J_{\mathrm{C}-4, \mathrm{P}}=3.7 \mathrm{~Hz} ; \mathrm{C}-6\right.$ : $\delta_{\mathrm{C}} 130.6,{ }^{3} J_{\mathrm{C}-6, \mathrm{P}}=5.3 \mathrm{~Hz}$ ) showed that the $\mathrm{C}-5$ and $\mathrm{C}-1{ }^{\prime}$ were connected through a phosphate ester linkage. Based on the chemical formula, the remaining five methylene carbons were set between C-12 and C-16. The $E$ geometries of $\Delta_{2,3}$ and $\Delta_{6,7}$ were determined by $J$ values of $\mathrm{H}-2 / \mathrm{H}-3(J=15.7 \mathrm{~Hz})$ and $\mathrm{H}-6 / \mathrm{H}-7(J$ $=15.2 \mathrm{~Hz}$ ), respectively. The $E$ configuration at $\Delta_{18,19}$ was established by the $\delta$ values of the allylic carbons $\left(\delta_{\mathrm{C}} 32.8(\mathrm{C}-17)\right.$ and $\left.33.2(\mathrm{C}-20)\right)$ as like 1 and the biosynthetic relationship. Based on the results described above, $\mathbf{3}$ was indicated to be a 24-membered macrolide containing phosphocholine moiety at C-5 of $\mathbf{1}$. 


\section{Isolation of AKML D (4)}

AO-akmlABCD was cultivated in CPS medium $(3.6 \mathrm{~L} ; 150 \mathrm{~mL} \times 24)$ at $30^{\circ} \mathrm{C}$ for 5 days. The cultured mycelia were harvested, freeze-dried, crushed to powder and extracted with $\mathrm{MeOH}$ twice. The $\mathrm{MeOH}$ solution was separated with $n$-hexane, and the $\mathrm{MeOH}$ extracts $(500 \mathrm{mg}$ ) were obtained. The $\mathrm{MeOH}$ extracts was separated by ODS reversed-phase column chromatography eluted with EtOAc-MeOH (2/1) with $1 \%$ water to give mixture 4 . The mixture 20 was separated by reversed-phase preparative TLC (acetonitrile: water $=2: 1)$ to afford $\mathbf{4}(11.2 \mathrm{mg})$.

AKML D (4): Colorless amorphous, Chemical formula $\mathrm{C}_{26} \mathrm{H}_{46} \mathrm{NO}_{9} \mathrm{P}$, HRESIMS: $\mathrm{m} / \mathrm{z} 546.2844$ [M-H] (546.2832 calcd. for $\left.\mathrm{C}_{26} \mathrm{H}_{45} \mathrm{NO}_{9} \mathrm{P}\right),[\alpha]_{\mathrm{D}}^{22}+26.8$ (c 0.33, MeOH); UV (EtOH) $\lambda_{\max } \mathrm{nm}(\log \varepsilon) 204$ (4.10); IR (KBr) $v_{\max }\left(\mathrm{cm}^{-1}\right) 3398,3272,2925,2853,1715,1654,1458,1217,1179,1074,1029$.

\section{D structure determination of AKML D (4)}

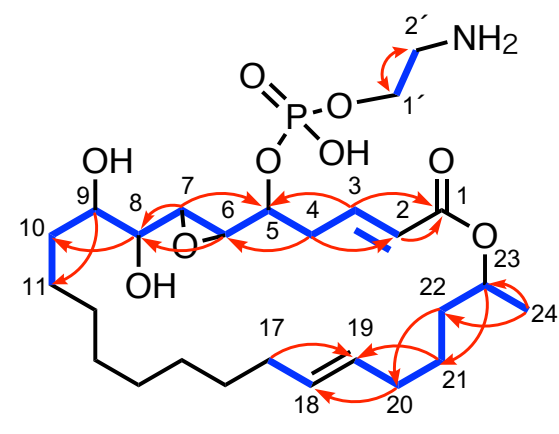

4

$\longrightarrow{ }^{1} \mathrm{H}-{ }^{1} \mathrm{H}$ COSY $\longrightarrow \mathrm{HMBC}$

AKML D (4) had a molecular formula of $\mathrm{C}_{26} \mathrm{H}_{46} \mathrm{NO}_{9} \mathrm{P}$, as indicated by its negative HRESIMS $(\mathrm{m} / \mathrm{z}$ 546.2844 $[\mathrm{M}-\mathrm{H}]^{-}$, calcd 546.2832). All protons and carbons are assigned based on 1D and several 2D NMR spectra analysis (Table S7), showing that the macrolide backbone of 4 was same as 1-3. Comparing the ${ }^{1} \mathrm{H}$ and ${ }^{13} \mathrm{C}$ NMR spectra of $\mathbf{4}$ with those of $\mathbf{2}$ and $\mathbf{3}$, the existence of an epoxide at C-6 and C-7 and a phosphoethanolamine moiety was indicated. The relative stereochemistry of the epoxide was determined as trans from its $J$ values of $\mathrm{H}-6 / \mathrm{H}-7(J=2.3 \mathrm{~Hz})$. The phosphoethanolamine residue was indicated to attach at C-5 as the same as 3 by the observation of doublet signals of the carbons at C-5 $\left(\delta_{\mathrm{C}} 75.8,{ }^{2} J_{\mathrm{C}}\right.$ $\left.{ }_{5, \mathrm{P}}=5.6 \mathrm{~Hz}\right)$ and $\mathrm{C}-1^{\prime}\left(\delta_{\mathrm{C}} 61.4,{ }^{2} J_{\mathrm{C}-1^{\prime}, \mathrm{P}}=5.3 \mathrm{~Hz}\right)$, and the adjacent carbons $\left(\mathrm{C}-4: \delta_{\mathrm{C}} 35.8\right.$, br d; C-6: $\delta_{\mathrm{C}} 57.8$, $\left.{ }^{3} J_{\mathrm{C}-6, \mathrm{P}}=5.6 \mathrm{~Hz} ; \mathrm{C}-2^{\prime}: \delta_{\mathrm{C}} 57.8,{ }^{3} J_{\mathrm{C}-2^{\prime}, \mathrm{P}}=6.2 \mathrm{~Hz}\right)$. The geochemistry of the olefin at $\left.\mathrm{C}-2\right)$ was established as trans from its $J$ values of $\mathrm{H}-2 / \mathrm{H}-3(J=15.7 \mathrm{~Hz})$. The $E$ configuration at $\Delta_{18,19}$ was determined by the $\delta$ values of the allylic carbons $\left(\delta_{\mathrm{C}} 31.4(\mathrm{C}-17)\right.$ and $\left.31.7(\mathrm{C}-20)\right)$ as like $\mathbf{1}$ and from the point of view of biosynthesis. From these data, we decided the 2D-structure of $\mathbf{4}$ as shown (Figure 3). 
Table S7. ${ }^{13} \mathrm{C}(125 \mathrm{MHz})$ and ${ }^{1} \mathrm{H}(500 \mathrm{MHz})$ NMR data for AKMLs A-D (1-4) ${ }^{a}$.

\begin{tabular}{|c|c|c|c|c|c|c|c|c|}
\hline \multicolumn{3}{|c|}{ AKML A $(\mathbf{1})^{b}$} & \multicolumn{2}{|c|}{ AKML B (2) } & \multicolumn{2}{|c|}{ AKML C (3) } & \multicolumn{2}{|c|}{${\mathrm{AKML} \mathrm{D}(4)^{c}}^{c}$} \\
\hline Position & ${ }^{13} \mathrm{C}$ & ${ }^{\mathrm{T}} \mathrm{H}$ (multi, $J$ in $\left.\mathrm{Hz}\right)$ & ${ }^{13} \mathrm{C}$ & ${ }^{\mathrm{T}} \mathrm{H}$ (multi, $J$ in $\mathrm{Hz}$ ) & ${ }^{13} \mathrm{C}$ & ${ }^{\mathrm{T}} \mathrm{H}$ (multi, $J$ in $\mathrm{Hz}$ ) & ${ }^{13} \mathrm{C}$ & ${ }^{\mathrm{T}} \mathrm{H}$ (multi, $J$ in $\mathrm{Hz}$ ) \\
\hline 1 & 165.9 & & 167.6 & & 167.5 & & 166.1 & \\
\hline 2 & 124.5 & $5.85(1 \mathrm{H}, \mathrm{dt}, 15.8,1.3)$ & 125.2 & $5.93(1 \mathrm{H}, \mathrm{d}, 15.6)$ & 125.4 & $5.87(1 \mathrm{H}, \mathrm{d}, 15.7)$ & 124.5 & $5.99(1 \mathrm{H}, \mathrm{d}, 15.7)$ \\
\hline 3 & 143.6 & $6.88(1 \mathrm{H}, \mathrm{dt}, 15.8,7.5)$ & 145.7 & $7.02(1 \mathrm{H}, \mathrm{dt}, 15.6,7.4)$ & 145.3 & $6.90(1 \mathrm{H}, \mathrm{d}, 15.7,7.4)$ & 143.1 & $7.05(1 \mathrm{H}, \mathrm{dd}, 15.7,7.5)$ \\
\hline 4 & 39.7 & $2.49(2 \mathrm{H}, \mathrm{m})$ & 38.1 & $2.52(1 \mathrm{H}, \mathrm{m})$ & 40.2 & $2.63(1 \mathrm{H}, \mathrm{m})$ & 35.8 & $\begin{array}{l}2.75(1 \mathrm{H}, \mathrm{m}) \\
2.71(1 \mathrm{H})\end{array}$ \\
\hline 5 & 71.6 & $4.28(1 \mathrm{H}, \mathrm{m})$ & 71.9 & $3.51(1 \mathrm{H}, \mathrm{m})$ & 76.6 & $4.70(1 \mathrm{H}, \mathrm{m})$ & 75.7 & $3.97(1 \mathrm{H}, \mathrm{m})$ \\
\hline 6 & 134.5 & $5.55(1 \mathrm{H}, \mathrm{dd}, 15.4,7.0)$ & 60.8 & $2.93(1 \mathrm{H}, \mathrm{m})$ & 133.0 & $5.51(1 \mathrm{H}, \mathrm{dd}, 15.5,7.3)$ & 57.8 & $3.09(1 \mathrm{H}, \mathrm{dd}, 7.4,2.3)$ \\
\hline 7 & 128.7 & $5.67(1 \mathrm{H}, \mathrm{dt}, 15.4,7.1)$ & 58.7 & $2.92(1 \mathrm{H}, \mathrm{m})$ & 130.9 & $5.71(1 \mathrm{H}, \mathrm{dt}, 15.5,7.4)$ & 58.0 & $3.03(1 \mathrm{H}, \mathrm{dd}, 6.5,2.3)$ \\
\hline 8 & 39.8 & $2.24(1 \mathrm{H}, \mathrm{m})$ & 76.9 & $3.09(1 \mathrm{H}, \mathrm{t}, 6.8)$ & 41.0 & $2.21(2 \mathrm{H}, \mathrm{m})$ & 74.4 & $3.16(1 \mathrm{H}, \mathrm{m})$ \\
\hline 9 & 70.9 & $3.66(1 \mathrm{H}, \mathrm{dt}, 11.7,6.0)$ & 74.0 & $3.51(1 \mathrm{H}, \mathrm{m})$ & 71.7 & $3.59(1 \mathrm{H}, \mathrm{m})$ & 72.4 & $3.53(1 \mathrm{H}, \mathrm{m})$ \\
\hline & & $1.47(1 \mathrm{H}, \mathrm{m})$ & & $1.55(1 \mathrm{H}, \mathrm{m})$ & & $1.47(1 \mathrm{H}, \mathrm{m})$ & & $1.45(1 \mathrm{H}, \mathrm{m})$ \\
\hline 11 & 24.7 & $1.31(2 \mathrm{H}, \mathrm{m})$ & 26.6 & $1.54(2 \mathrm{H}, \mathrm{m})$ & 25.8 & $1.31(2 \mathrm{H}, \mathrm{m})$ & 25.2 & $1.40(2 \mathrm{H}, \mathrm{m})$ \\
\hline $\begin{array}{l}12 \\
13\end{array}$ & $\begin{array}{l}27.7^{d} \\
28.47^{d}\end{array}$ & & $\begin{array}{l}29.3^{e} \\
30.0^{e}\end{array}$ & & $28.8^{h}$ & & $27.4^{j}$ & \\
\hline 14 & $28.51^{d}$ & $1.27-1.34(10 \mathrm{H})$ & $30.2^{e}$ & $1.27-1.34(10 \mathrm{H})$ & $29.7^{h}$ & $1.30-1.42(10 \mathrm{H})$ & 28.4 & $1.27-1.37(10 \mathrm{H})$ \\
\hline 15 & $28.76^{d}$ & 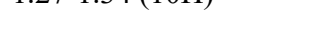 & $30.4^{e}$ & $1.21-1.04(1011)$ & $30.17^{h}$ & $1.00-1.42(1011)$ & $28.7^{j}$ & $1.52-1.07($ (IVI) \\
\hline 16 & $28.83^{d}$ & & $30.4^{e}$ & & $30.21^{h}$ & & $28.8^{j}$ & \\
\hline 17 & 31.8 & $2.00(2 \mathrm{H}, \mathrm{m})$ & 33.05 & $2.00(2 \mathrm{H}, \mathrm{m})$ & 32.8 & $2.00(2 \mathrm{H}, \mathrm{m})$ & 31.4 & $2.00(2 \mathrm{H}, \mathrm{m})$ \\
\hline 18 & 130.8 & $5.35(1 \mathrm{H}, \mathrm{m})$ & $131.8^{g}$ & $5.36(1 \mathrm{H}, \mathrm{m})$ & 132.1 & $5.35(1 \mathrm{H}, \mathrm{m})$ & $130.6^{l}$ & $5.35(1 \mathrm{H}, \mathrm{m})$ \\
\hline 19 & 130.1 & $5.35(1 \mathrm{H}, \mathrm{m})$ & $131.4^{g}$ & $5.36(1 \mathrm{H}, \mathrm{m})$ & 131.5 & $5.35(1 \mathrm{H}, \mathrm{m})$ & $130.1^{l}$ & $5.35(1 \mathrm{H}, \mathrm{m})$ \\
\hline 20 & 32.3 & $1.96(1 \mathrm{H}, \mathrm{m})$ & 33.10 & $2.00(2 \mathrm{H}, \mathrm{m})$ & 33.2 & $2.00(2 \mathrm{H}, \mathrm{m})$ & 31.7 & $2.00(2 \mathrm{H}, \mathrm{m})$ \\
\hline 22 & 35.2 & $1.47(1 \mathrm{H}, \mathrm{m})$ & 36.2 & $1.53(1 \mathrm{H}, \mathrm{m})$ & 36.2 & $1.47(1 \mathrm{H}, \mathrm{m})$ & 34.8 & $1.64(1 \mathrm{H}, \mathrm{m})$ \\
\hline & & $1.62(1 \mathrm{H}, \mathrm{m})$ & & $1.65(1 \mathrm{H}, \mathrm{m})$ & & $1.63(1 \mathrm{H}, \mathrm{m})$ & & $1.50(1 \mathrm{H}, \mathrm{m})$ \\
\hline 23 & 71.1 & $4.96(1 \mathrm{H}, \mathrm{m})$ & 72.4 & $4.94(1 \mathrm{H}, \mathrm{m})$ & 72.4 & $4.92(1 \mathrm{H}, \mathrm{m})$ & 71.1 & $4.92(1 \mathrm{H}, \mathrm{m})$ \\
\hline 24 & 20.1 & $1.23(3 \mathrm{H}, \mathrm{d}, 6.3)$ & 20.4 & $1.23(3 \mathrm{H}, \mathrm{d}, 6.3)$ & 20.3 & $1.21(3 \mathrm{H}, \mathrm{d}, 6.3)$ & 18.9 & $1.22(3 \mathrm{H}, \mathrm{d}, 6.3)$ \\
\hline $1^{\prime}$ & & & & & 62.8 & $4.00(2 \mathrm{H}, \mathrm{m})$ & 61.4 & $4.08(2 \mathrm{H}, \mathrm{m})$ \\
\hline $2^{\prime}$ & & & & & 41.7 & $3.12(2 \mathrm{H}, \mathrm{m})$ & 40.3 & $3.16(2 \mathrm{H}, \mathrm{m})$ \\
\hline
\end{tabular}

[a] Assignments were based on ${ }^{1} \mathrm{H}-{ }^{1} \mathrm{H}$ COSY, HSQC, HMBC (and HSQC-TOCSY) experiments.

[b] Recorded in $\mathrm{CDCl}_{3}$. [c] Recorded in $\mathrm{CD}_{3} \mathrm{OD}$. [d-k] Interchangeable 


\section{Determination of the absolute configurations of AKMLs A-D (1-4)}

AKMLs A-D (1-4) have chiral centers at C-5, C-9 and C-23 and 2 and 4 have additional three ones at C-6, C-7 and C-8. To determine the absolute configurations at C-9 and C-23, 1 was used for chemical derivatization and the advanced Mosher's method (Figure S4A) and $\mathbf{2}$ was conducted chemical conversion, the advanced Mosher's method for C-5 and C-8 (Figure S4B), and NMR calculation for C-6 and C-7 (Table S11). The remaining all configurations of 1-4 were determined to be the same as $\mathbf{1}$ and $\mathbf{2}$ from the point of view of biosynthesis.

Firstly, 1 was chemically converted to MTPA derivatives $11 \mathbf{a}$ and $\mathbf{1 1 b}$ and their $\Delta \delta_{\mathrm{H}(S-R)}$ values showed $R$-configurations at C-9 and C-23 of $\mathbf{1}$ (Figure S4A). Compound $\mathbf{2}$ was also derivatized to MTPA esters 14a and 14b and $S$-configuration at C-5 was established (Figure S4B). Next, we determined the relative configuration at C-8 and C-9 as trans by the NOESY spectrum of acetonide derivative 15, showing the absolute configuration at C-8 is $S$ because that of C-9 had already revealed as $R$ (Figure S4B). The trans conformer of the epoxide of 2 was characterized by $J$ values of H-6/H-7 $(J=2.3 \mathrm{~Hz})$ of 4 from the viewpoint of biosynthesis. The configuration of epoxide moiety relative to C-5, C-8, and C-9 was determined by GIAO 13C NMR calculations and DP4 analysis (Table S11). From these results above, the absolute configuration of AKMLs A-D (1-4) were established as depicted below.
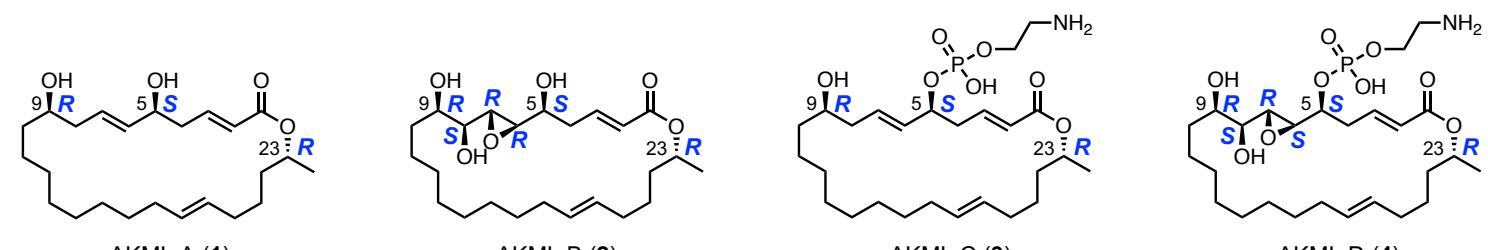

AKML A (1)

AKML B (2)

AKML C (3)

AKML D (4)

(A) Determination of absolute configuration at C-9 and C-23 of 1

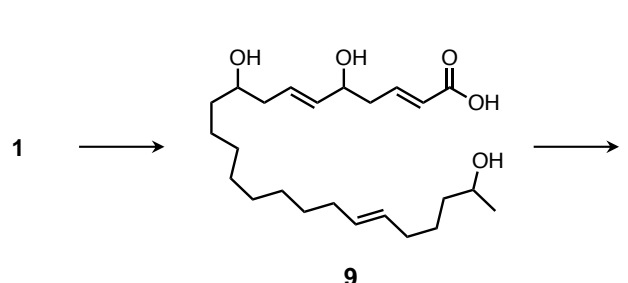

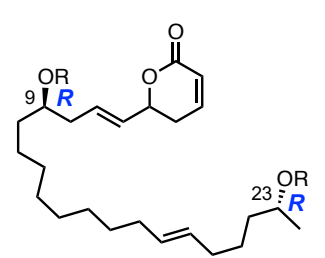

$10: \mathrm{R}=\mathrm{H}$ $11 \mathrm{a} / \mathrm{b}: \mathrm{R}=(S / R)-\mathrm{MTPA}$

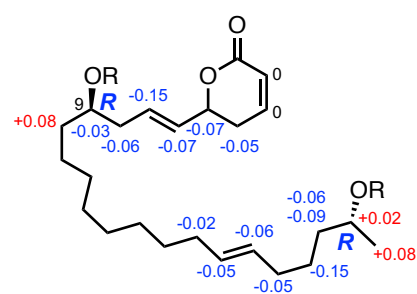

11a/b : R $=(S / R)-M T P A$

(B) Determination of absolute configuration at C-8 and C-9 of 2

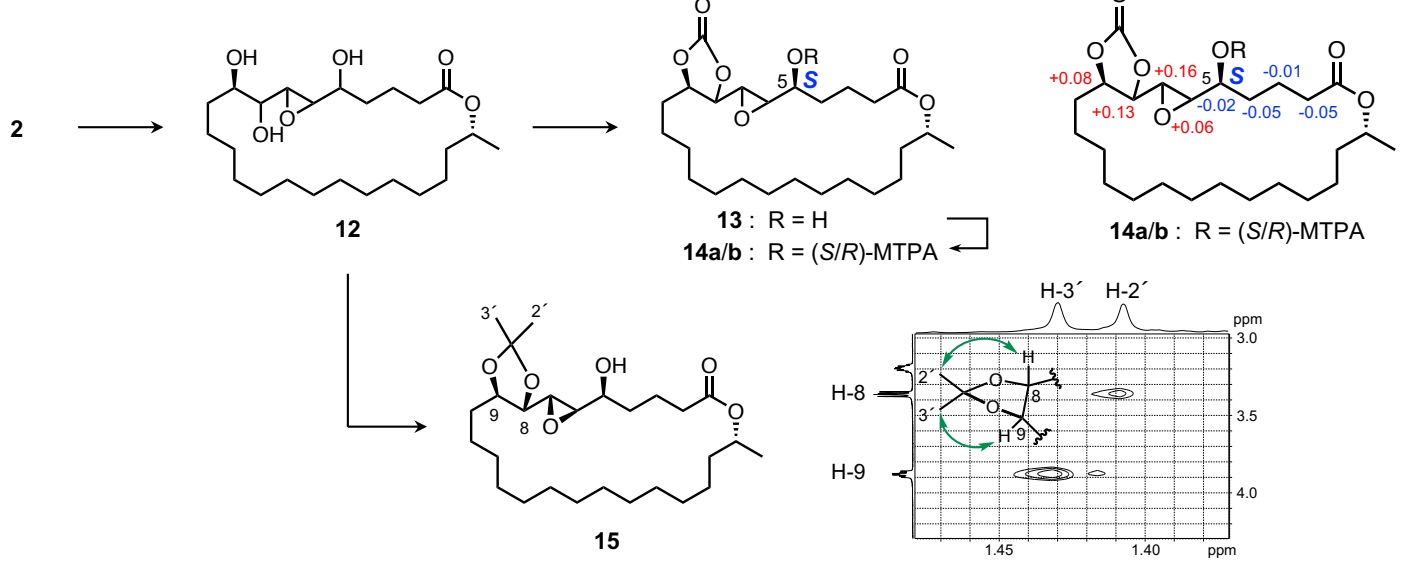

Figure S4. Determination of absolute configurations of AKMLs A-D. Schemes for determining absolute configurations at (A) C-9 and C-23 of $\mathbf{1}$ and (B) C-8 and C-9 of $\mathbf{2}$. The $\Delta \delta_{\mathrm{H}(S-R)}$ values (parts per million) of 11a and 11b, and 14a and 14b were shown in red or blue. 


\section{Synthesis of 9}<smiles></smiles>

AKML A (1)

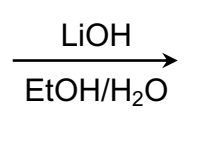<smiles>C[C@H](O)CCC/C=C/CCCCCCCCC(O)C/C=C/C(O)/C=C/C(=O)O</smiles>

9

AKML A (1) $(8.6 \mathrm{mg}, 21.9 \mu \mathrm{mol})$ was dissolved in $200 \mu \mathrm{L} \mathrm{EtOH}$ and a $2 \mathrm{~N}$ aqueous $\mathrm{LiOH}$ solution $(200 \mu \mathrm{L})$ was added, and the reaction was stirred for $16 \mathrm{~h}$ at room temperature. To the reaction mixture was added $1 \mathrm{~N}$ aqueous $\mathrm{HCl}$ solution $(c a .420 \mu \mathrm{L})(\mathrm{pH}$ of the aqueous layer $<2)$ and extracted with EtOAc (x5) and concentrated in vacuo. The crude $9(8.4 \mathrm{mg})$ were subjected to a flash silica gel column chromatography eluted with $\mathrm{CHCl}_{3}-\mathrm{MeOH}(20 / 1)$ to give $9(5.0 \mathrm{mg})$. HRESIMS analysis of the extract showed the presence of pure $9\left(\mathrm{~m} / z\right.$ 409.2962 [M-H] ${ }^{-}$, calcd. 409.2959).

Compound 9: Colorless amorphous, HRESIMS: $m / z 409.2962$ [M-H] $]^{-}\left(409.2959\right.$ calcd. for $\mathrm{C}_{24} \mathrm{H}_{41} \mathrm{O}_{5}$ ), ${ }^{1} \mathrm{H}$ NMR $\left(500 \mathrm{MHz}, \mathrm{CD}_{3} \mathrm{OD}\right) ; \delta=6.86$ (dd, 15.6, 7.3, H-3), 5.85 (d, 15.6, H-2), 5.71 (dt, 15.4, 7.1, H-7), 5.53 (dd, 15.4, 6.7, H-6), 5.40 (m, H-18), 5.40 (m, H-19), 4.15 (m, H-5), 3.70 (m, H-23), 3.56 (m, H-9), 2.40 (m, H2-4), 2.18 (m, H2-8), 1.98 (m, $\mathrm{H}_{2}-17$ ), 1.98 (m, H-20), 1.39-1.46 (m, $\left.\mathrm{H}_{2}-10\right), 1.39-1.45$ (m, $\mathrm{H}_{2}-$ 22), 1.34-1.37 (m, H-21), 1.31-1.40 (m, 12H), $1.13\left(\mathrm{~d}, 6.2, \mathrm{H}_{3}-24\right)$

\section{Synthesis of 10}

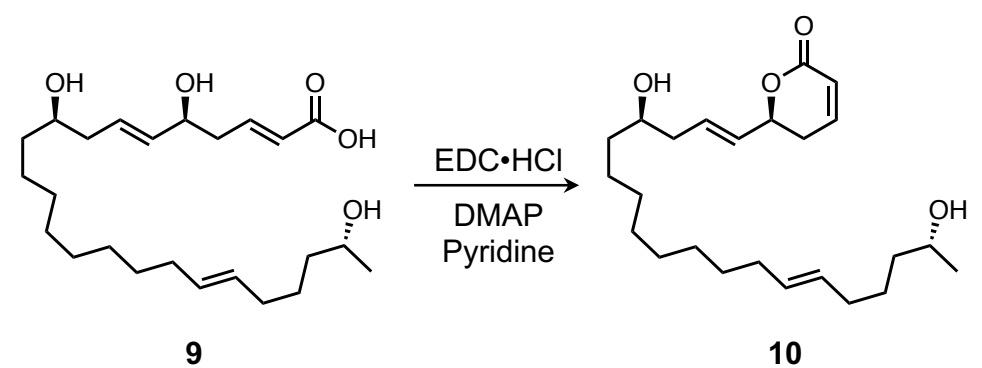

Compound $9(4.8 \mathrm{mg}, 11.7 \mu \mathrm{mol})$ was dissolved in $350 \mu \mathrm{L}$ pyridine and DMAP (cat.) and EDC $\cdot \mathrm{HCl}$ $(4.5 \mathrm{mg}, 23.4 \mu \mathrm{mol})$ were added on ice, and the reaction was stirred for $3 \mathrm{~h}$ at room temperature. To the reaction mixture was added $0.1 \mathrm{~N}$ aqueous $\mathrm{HCl}$ solution and extracted with EtOAc (x5) and concentrated in vacuo. The crude $10(5.0 \mathrm{mg})$ were subjected to a flash silica gel column chromatography eluted with $n$-hexane-EtOAc (1/1) to give mixture of $\mathbf{1 0}(3.0 \mathrm{mg})$. The mixture was separated by a flash silica gel column chromatography eluted with $\mathrm{CHCl}_{3}-\mathrm{MeOH}$ (40/1-19/1) to afford 10 (2.1 mg). HRESIMS analysis of the extract showed the presence of $\mathbf{1 0}(\mathrm{m} / \mathrm{z} 415.2821$ [M-H]', calcd. 415.2819).

Compound 10: Colorless amorphous, HRESIMS: $m / z$ 415.2821 $[\mathrm{M}+\mathrm{Na}]^{+}(415.2819$ calcd. for $\mathrm{C}_{24} \mathrm{H}_{40} \mathrm{O}_{4} \mathrm{Na}$ ), all protons and carbons were assigned as Table S8. 


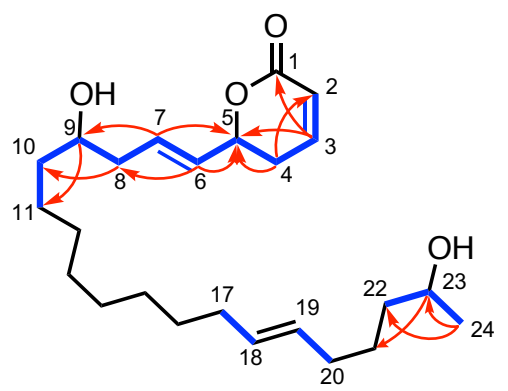

Table S8. ${ }^{13} \mathrm{C}(125 \mathrm{MHz})$ and ${ }^{1} \mathrm{H}(500 \mathrm{MHz})$ NMR data for $10^{a, b}$.

\begin{tabular}{lrl}
\hline $\mathbf{1 0}$ & & \\
\hline Position & \multicolumn{1}{c}{${ }^{3} \mathrm{C}$} & ${ }^{\mathrm{T}}$ (multi, $J$ in Hz) \\
\hline 1 & 164.0 & \\
2 & 121.6 & $6.05(1 \mathrm{H}, \mathrm{dt}, 9.8,1.8)$ \\
3 & 144.6 & $6.88(1 \mathrm{H}, \mathrm{dt}, 9.8,4.2)$ \\
4 & 29.7 & $2.45(2 \mathrm{H}, \mathrm{m})$ \\
5 & 77.8 & $4.91(1 \mathrm{H}, \mathrm{m})$ \\
6 & 129.9 & $5.70(1 \mathrm{H}, \mathrm{dd}, 15.5,6.4)$ \\
7 & 131.3 & $5.89(1 \mathrm{H}, \mathrm{m})$ \\
8 & 40.2 & $2.19(1 \mathrm{H}, \mathrm{ddd}, 14.3,7.5,7.5)$ \\
& & $2.30(1 \mathrm{H}, \mathrm{m})$ \\
9 & 70.8 & $3.66(1 \mathrm{H}, \mathrm{m})$ \\
10 & 36.9 & $1.45(2 \mathrm{H}, \mathrm{m})$ \\
11 & 25.6 & $1.29-1.35(2 \mathrm{H}, \mathrm{m})$ \\
12 & $29.1^{c}$ & \\
13 & $29.4^{c}$ & \\
14 & $29.5^{c}$ & $1.24-1.37(10 \mathrm{H}, \mathrm{m})$ \\
15 & $29.5^{c}$ & \\
16 & $29.5^{c}$ & \\
17 & 32.5 & $1.96^{e}(2 \mathrm{H}, \mathrm{m})$ \\
18 & $129.9^{d}$ & $5.39(2 \mathrm{H}, \mathrm{m})$ \\
19 & $130.8^{d}$ & $5.39(2 \mathrm{H}, \mathrm{m})$ \\
20 & 32.5 & $2.00^{e}(2 \mathrm{H}, \mathrm{m})$ \\
21 & 25.7 & $1.37-1.46(2 \mathrm{H}, \mathrm{m})$ \\
22 & 38.8 & $1.43(2 \mathrm{H}, \mathrm{m})$ \\
23 & 68.1 & $3.80(1 \mathrm{H}, \mathrm{m})$ \\
24 & 23.5 & $1.19(3 \mathrm{H}, \mathrm{d}, 6.2)$ \\
\hline
\end{tabular}

[a] Assignments were based on ${ }^{1} \mathrm{H}-{ }^{1} \mathrm{H}$ COSY, HSQC and HMBC experiments. [b] Recorded in $\mathrm{CDCl}_{3}$. [c-e] Interchangeable.

\section{Synthesis of $11 \mathrm{a} / \mathrm{b}$}

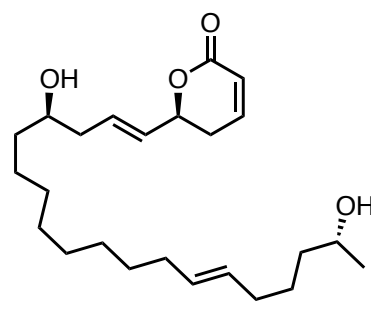

10

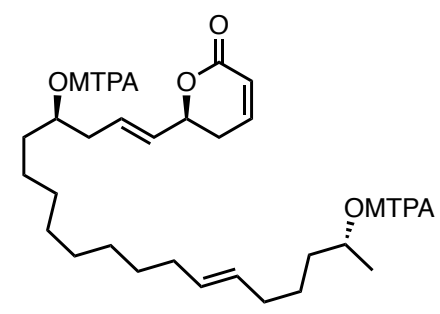

11a/b (S/R-MTPA)

For the synthesis of the $(S)$-MTPA ester, $10(0.5 \mathrm{mg}, 1.3 \mu \mathrm{mol})$ was dissolved in $50 \mu \mathrm{L}$ pyridine and $(R)$-MTPA chloride $(4.8 \mu \mathrm{L}, 25.4 \mu \mathrm{mol})$ was added on ice. The mixture was stirred at room temperature for $2.5 \mathrm{~h}$ and then water was added. The water layer was extracted with EtOAc (x5) and concentrated in vacuo. The resulting mixture $(9.3 \mathrm{mg})$ were subjected to a flash silica gel column chromatography eluted with $n$-hexane-EtOAc (4/1-3/1) to give (S)-MTPA ester 11a $(0.5 \mathrm{mg})$. The $(R)$-MTPA ester 11b $(0.7 \mathrm{mg})$ was prepared in the same manner by the addition of $(S)$-MTPA chloride $(4.8 \mu \mathrm{L}, 25.4 \mu \mathrm{mol})$. The complete assignment of all protons was achieved using ${ }^{1} \mathrm{H}-{ }^{1} \mathrm{H}$ COSY experiment and comparing ${ }^{1} \mathrm{H}$ NMR of 11a and $11 \mathrm{~b}$. 
Compound 11a: Colorless amorphous, HRESIMS: $m / z$ 847.3624 $[\mathrm{M}+\mathrm{Na}]^{+}(847.3615$ calcd. for $\mathrm{C}_{44} \mathrm{H}_{54} \mathrm{~F}_{6} \mathrm{O}_{8} \mathrm{Na}$ ), ${ }^{1} \mathrm{H}$ NMR (500 MHz, $\mathrm{CDCl}_{3}$ ); $\delta=6.85$ (ddd, 9.8, 5.2, 3.3, H-3), 6.04 (brd, 9.8, H-2), 5.62 (m, H-7), 5.60 (m, H-6), 5.35 (m, H-18), 5.28 ${ }^{a}$ (m, H-19), 5.16 (m, H-23), 5.12 (m, H-9), 4.77 (m, H-5), 2.38 (m, $\mathrm{H}_{2}-8$ ), 2.32 (m, Ha-4), 2.30 (m, Hb-4), 1.94 (m, $\left.\mathrm{H}_{2}-17\right), 1.94$ (m, $\left.\mathrm{H}_{2}-20\right), 1.60-1.68$ (m, $\left.\mathrm{H}_{2}-10\right)$, 1.49-1.62 (m, $\left.\mathrm{H}_{2}-22\right), 1.33$ (d, 6.3, $\left.\mathrm{H}_{3}-24\right), 1.20-1.35$ (m, $\left.12 \mathrm{H}\right), 1.26\left(\mathrm{~m}, \mathrm{H}_{2}-21\right)$. [a] interchangeable.

Compound 11b: Colorless amorphous, HRESIMS: $m / z$ 847.3622 $[\mathrm{M}+\mathrm{Na}]^{+}(847.3615$ calcd. for $\mathrm{C}_{44} \mathrm{H}_{54} \mathrm{~F}_{6} \mathrm{O}_{8} \mathrm{Na}$ ), ${ }^{1} \mathrm{H}$ NMR $\left(500 \mathrm{MHz}, \mathrm{CDCl}_{3}\right.$ ); $\delta=6.85$ (ddd, 9.8, 4.7, 3.7, H-3), 6.04 (dt, 9.8, 1.8, H-2), 5.77 (dt, 15.5, 6.8, H-7), 5.67 (dd, 15.5, 6.1, H-6), 5.34 (m, H-19), 5.40 (m, H-18), 5.14 (m, H-23), 5.15 (m, H-9), 4.84 (m, H-5), 2.44 (t, 6.4, H2-8), 2.37 (m, Ha-4), 2.35 (m, Hb-4), 1.99 (m, $\mathrm{H}_{2}-20$ ), 1.96 (m, $\mathrm{H}_{2-}$ 17), 1.68 (m, Ha-10), 1.52 (m, Hb-10), 1.58-1.68 (m, $\left.\mathrm{H}_{2}-22\right), 1.41$ (m, $\left.\mathrm{H}_{2}-21\right), 1.25$ (d, 6.3, $\left.\mathrm{H}_{3}-24\right), 1.15-$ $1.31(\mathrm{~m}, 12 \mathrm{H})$.

\section{Synthesis of 13}
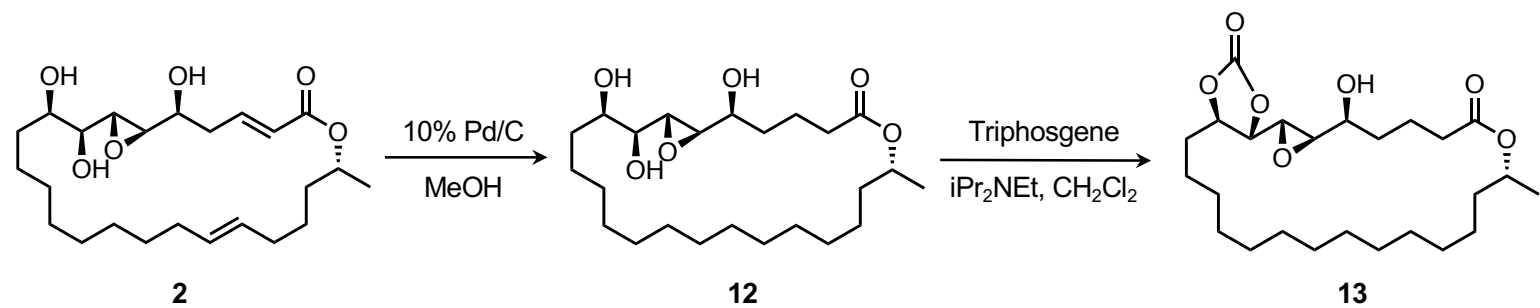

To a solution of $2(7.5 \mathrm{mg}, 0.0177 \mathrm{mmol})$ in $\mathrm{MeOH}(3.0 \mathrm{~mL})$ was added $10 \% \mathrm{Pd} / \mathrm{C}(10.0 \mathrm{mg})$ at room temperature. After being stirred under $\mathrm{H}_{2}(1 \mathrm{~atm})$ for $2.5 \mathrm{~h}$ at room temperature, the reaction mixture was filtered through Celite ${ }^{\mathbb{B}}$ pad and concentrated in vacuo. The crude material was used for the next reaction without further purification.

To a solution of crude 12 in $\mathrm{CH}_{2} \mathrm{Cl}_{2}(0.50 \mathrm{~mL})$ were successively added $\operatorname{Pr}_{2} \mathrm{NEt}(62 \mu \mathrm{L}, 0.353 \mathrm{mmol})$ and Triphosgene $(12.6 \mathrm{mg}, 0.0424 \mathrm{mmol})$ at $0^{\circ} \mathrm{C}$. After being stirred for $14 \mathrm{~h}$ at room temperature, the reaction was stopped by adding saturated aqueous $\mathrm{NaHCO}_{3}$. The crude products were extracted with EtOAc $(\mathrm{x} 4)$ and the combined organic extracts were washed with brine, dried $\left(\mathrm{Na}_{2} \mathrm{SO}_{4}\right)$, and concentrated in vacuo. The crude sample $(13.2 \mathrm{mg})$ were subjected to a flash silica gel column chromatography eluted with $n$-hexane-EtOAc (2/1) to give $\mathbf{1 3}(3.5 \mathrm{mg})$.

Compound 13: Colorless amorphous, ${ }^{1} \mathrm{H}$ NMR $\left(500 \mathrm{MHz}, \mathrm{CDCl}_{3}\left(20 \% \mathrm{CD}_{3} \mathrm{OD}\right)\right) ; \delta=4.96(\mathrm{~m}, \mathrm{H}-23)$, 4.54 (dt, 6.8, 6.8, H-9), 4.23 (dd, 6.8, 5.1, H-8), 3.62 (m, H-5), 3.21 (dd, 5.1, 2.1, H-7), 3.11 (dd, 4.5, 2.1, H-6), 2.38 (t, 6.8, H2-2), 1.92 (m Hb-10), 1.85 (m, Hb-3), 1.74 (m, Ha-3), 1.74 (m, Ha-10), 1.69 (m, $\mathrm{H}_{2-}$ 4), 1.60 (m, Hb-22), 1.49 (m, Ha-22), 1.23 (d, 6.3, $\left.\mathrm{H}_{3}-24\right), 1.26-1.46(22 \mathrm{H}) .{ }^{13} \mathrm{C} \mathrm{NMR}\left(125 \mathrm{MHz}, \mathrm{CDCl}_{3}\right.$ $\left.\left(20 \% \mathrm{CD}_{3} \mathrm{OD}\right)\right) ; \delta=173.0(\mathrm{C}-1), 153.7\left(\mathrm{C}-1^{\prime}\right), 80.2$ (C-8), 78.4 (C-9), 71.0 (C-23), 69.6 (C-5), 58.3 (C6), 54.5 (C-7), 35.6 (C-22), 33.4 (C-4), 33.1 (C-10), 20.5 (C-3), 20.1 (C-24), 23.7, 25.0, 28.0, 28.3, 28.3, 28.5, 28.5, 28.5, 28.5, 28.5, 28.7 (C-11-C-21). 


\section{Synthesis of $14 a$ and $14 b$}

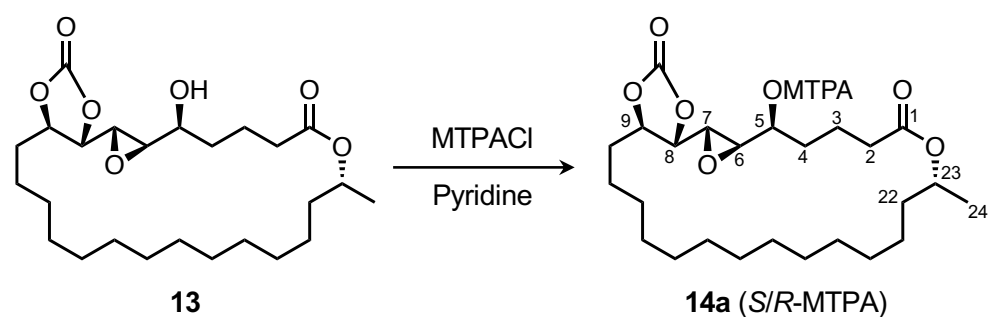

For the preparation of the $(S)$-MTPA ester, $\mathbf{1 3}(0.5 \mathrm{mg}, 1.1 \mu \mathrm{mol})$ was dissolved in $30 \mu \mathrm{L}$ pyridine and $(R)$-MTPA chloride $(1 \mu \mathrm{L}, 5.3 \mu \mathrm{mol})$ was added. The mixture was incubated for $1 \mathrm{~h}$ at room temperature and then EtOAc and water were added. The water layer was extracted with EtOAc twice and concentrated. The resulting mixture was separated by PTLC $(n$-hexane-EtOAc $=2 / 1)$ to give $(S)$-MTPA ester 14a $(0.5$ $\mathrm{mg})$. The $(R)$-MTPA ester $14 \mathbf{b}(0.5 \mathrm{mg})$ was prepared in the same manner by the addition of $(S)$-MTPA chloride $(1 \mu \mathrm{L}, 5.3 \mu \mathrm{mol})$. The complete assignment of all protons was achieved using ${ }^{1} \mathrm{H}-{ }^{1} \mathrm{H}$ COSY experiment and comparing ${ }^{1} \mathrm{H}$ NMR of $14 \mathbf{a}$ and $\mathbf{1 4 b}$.

Compound 14a: Colorless amorphous, HRESIMS: $m / z$ 693.3192 $[\mathrm{M}+\mathrm{Na}]^{+}$(693.3221calcd. for $\mathrm{C}_{34} \mathrm{H}_{47} \mathrm{~F}_{3} \mathrm{O}_{9} \mathrm{Na}$ ), ${ }^{1} \mathrm{H}$ NMR (500 MHz, $\mathrm{CDCl}_{3}$ ); $\delta=4.91$ (m, H-5), 4.91 (m, H-23), 4.53 (dt, 6.4, 6.4, H-9), 4.33 (dd, 6.4, 3.6, H-8), 3.30 (dd, 7.1, 2.0, H-6), 3.06 (m, H-7), 2.29 (m, $\left.\mathrm{H}_{2}-2\right), 1.76$ (m, $\left.\mathrm{H}_{2}-4\right), 1.66$ (m, $\mathrm{Hb}-3), 1.54$ (m, Ha-3), 1.20 (d, 6.3, H-24), 1.22-1.65 (26H).

Compound 14b: Colorless amorphous, HRESIMS: $m / z$ 693.3190 $[\mathrm{M}+\mathrm{Na}]^{+}$(693.3221calcd. for $\mathrm{C}_{34} \mathrm{H}_{47} \mathrm{~F}_{3} \mathrm{O}_{9} \mathrm{Na}$ ), ${ }^{1} \mathrm{H}$ NMR (500 MHz, $\mathrm{CDCl}_{3}$ ); $\delta=5.01$ (m, H-5), 4.93 (m, H-23), 4.45 (dt, 6.6, 6.6, H-9), 4.20 (dd, 6.6, 4.0, H-8), 3.24 (dd, 6.0, 2.1, H-6), 2.90 (dd, 4.0, 2.1, H-7), 2.34 (m, H $\mathrm{H}_{2}-2$ ), 1.81 (m, $\mathrm{H}_{2}-4$ ), 1.67 (m, $\left.\mathrm{H}_{2}-3\right), 1.21$ (d, 6.3, 3H-24), 1.24-1.64 (26H).

\section{Synthesis of 15}

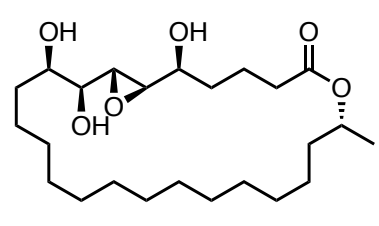

12

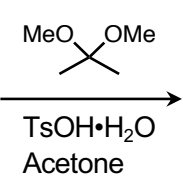
Acetone

To a solution of diol, $12(5.7 \mathrm{mg}, 0.013 \mathrm{mmol})$ in acetone $(1.0 \mathrm{~mL})$ were successively added 2,2dimethoxypropane $(10.0 \mu \mathrm{L}, 0.0798 \mathrm{mmol})$ and $\mathrm{TsOH} \cdot \mathrm{H}_{2} \mathrm{O}(0.8 \mathrm{mg}, 0.00399 \mathrm{mmol})$ at $0{ }^{\circ} \mathrm{C}$. After being stirred for $2.0 \mathrm{~h}$ at $0{ }^{\circ} \mathrm{C}$, the reaction was stopped by adding saturated aqueous $\mathrm{NaHCO}_{3}$ at $0{ }^{\circ} \mathrm{C}$. The crude products were extracted with EtOAc (x5) and the combined organic extracts were washed with brine, dried $\left(\mathrm{Na}_{2} \mathrm{SO}_{4}\right)$, and concentrated in vacuo.

The crude sample were subjected to a flash silica gel column chromatography eluted with $n$-hexaneEtOAc (3/1) to give $15(2.6 \mathrm{mg})$. HRESIMS analysis of the extract showed the presence of $\mathbf{1 5}(\mathrm{m} / \mathrm{z}$ 491.3335 $[\mathrm{M}+\mathrm{Na}]^{+}$, calcd. 491.3343). The NOESY correlations at $\mathrm{H}-8 / \mathrm{H}-1^{\prime}$ and $\mathrm{H}-9 / \mathrm{H}-2^{\prime}$ indicated the relative configuration at $\mathrm{C}-8$ and $\mathrm{C}-9$ as $8 S^{*}, 9 R^{*}$.

Compound 15: Colorless amorphous, HRESIMS: $m / z 491.3335[\mathrm{M}+\mathrm{Na}]^{+}(491.3343$ calcd. for $\mathrm{C}_{27} \mathrm{H}_{48} \mathrm{O}_{6} \mathrm{Na}$ ), ${ }^{1} \mathrm{H}$ NMR (500 MHz, $\mathrm{C}_{6} \mathrm{D}_{6}$ ); $\delta=5.04$ (m, H-23), 3.89 (m, H-9), 3.37 (dd, 8.4, 6.2, H-8), 3.20 (m, H-5), 2.88 (dd, 6.2, 2.2, H-7), 2.77 (dd, 5.3, 2.2, H-6), 2.14 (m, $\mathrm{H}_{2}-2$ ), 1.79 (m, Hb-3), 1.60 (m, Ha-3), 1.50 (m, Hb-22), 1.44 (s, $\left.\mathrm{H}_{3}-2^{\prime}\right), 1.42$ (s, $\left.\mathrm{H}_{3}-3^{\prime}\right), 1.37$ (m, $\left.\mathrm{H}_{2}-4\right), 1.30$ (m, Ha-22), 1.10 (d, 6.3, $\left.\mathrm{H}_{3}-24\right)$, 
1.23-1.44 (24H). ${ }^{13} \mathrm{C}$ NMR (125 MHz, $\left.\mathrm{C}_{6} \mathrm{D}_{6}\right) ; \delta=172.8$ (C-1), 109.6 (C-1'), 82.5 (C-8), 78.3 (C-9), 71.2 (C-5), 70.8 (C-23), 59.0 (C-6), 56.4 (C-7), 36.1 (C-22), 34.8 (C-2), 34.2 (C-4), 33.2 (C-10), 27.9 (C-2'), 27.4 (C-3'), 21.6 (C-3), 20.7 (C-24), 25.1, 26.3, 28.8, 28.9, 29.1, 29.4, 29.4, 29.5, 29.6, 29.6, 29.7 (C-11C-21).

\section{Isolation of CIML A (5) and CIML C (7)}

$\mathrm{AO}$-cimlABC was cultivated in CPS medium $(300 \mathrm{~mL} ; 150 \mathrm{~mL}$ x 2$)$ at $30^{\circ} \mathrm{C}$ for 5 days. The cultured mycelia were harvested, freeze-dried, crushed to powder and extracted with $\mathrm{MeOH}$ twice. The $\mathrm{MeOH}$ solution was separated with $n$-hexane, and the $\mathrm{MeOH}$ extracts $(30 \mathrm{mg}$ ) were obtained. The extract $(30 \mathrm{mg})$ was subjected to reversed-phage silica gel column chromatography eluted with $\mathrm{MeOH}$-water (9/1-20/1) to give mixture 5 and $7(14.0 \mathrm{mg})$. The mixture $(14.0 \mathrm{mg})$ was separated by reversed-phase preparative TLC $(\mathrm{MeOH}$ : water $=20: 1)$ to afford $\mathbf{5}(6.4 \mathrm{mg})$ and $7(3.4 \mathrm{mg})$.

CIML A (5): Colorless amorphous, Chemical formula $\mathrm{C}_{22} \mathrm{H}_{38} \mathrm{O}_{3}$, HRESIMS: $m / z 373.2722[\mathrm{M}+\mathrm{Na}]^{+}$ (373.2713 calcd. for $\mathrm{C}_{22} \mathrm{H}_{38} \mathrm{O}_{3} \mathrm{Na}$ ); $[\alpha]_{\mathrm{D}}{ }^{21}-7.8$ (c 0.80, EtOH); UV (EtOH) $\lambda_{\max } \mathrm{nm}(\log \varepsilon) 207$ (4.23; IR $(\mathrm{KBr}) v_{\max }\left(\mathrm{cm}^{-1}\right) 3445,2925,2854,1717,1686,1458,1270,1173,979$.

CIML C (7): Colorless amorphous, Chemical formula $\mathrm{C}_{27} \mathrm{H}_{50} \mathrm{NO}_{6} \mathrm{P}$, HRESIMS: $m / z 538.3278[\mathrm{M}+\mathrm{Na}]^{+}$ (538.3279 calcd. for $\left.\mathrm{C}_{27} \mathrm{H}_{51} \mathrm{NO}_{6} \mathrm{P}\right),[\alpha]_{\mathrm{D}}^{22} 0.0$ (c 0.37, MeOH); UV (EtOH) $\lambda_{\max } \mathrm{nm}(\log \varepsilon) 203$ (4.04) IR $(\mathrm{KBr}) v_{\max }\left(\mathrm{cm}^{-1}\right) 3396,2925,2853,1716,1653,1457,1232,1220,1087,1075,969$.

\section{D structure determination of CIML A (5)}

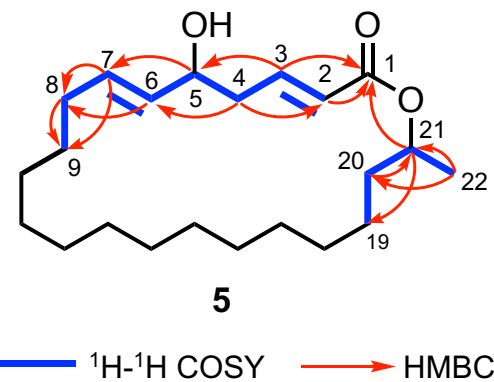

CIML A (5) had a molecular formula of $\mathrm{C}_{22} \mathrm{H}_{38} \mathrm{O}_{3}$, as established by its positive HRESIMS $(\mathrm{m} / \mathrm{z}$ $373.2722[\mathrm{M}+\mathrm{Na}]^{+}$, calcd 373.2713), and was also supported by ${ }^{1} \mathrm{H}$ and ${ }^{13} \mathrm{C}$ NMR data. IR spectrum indicated absorbance for ester carbonyl $\left(v_{\max } 1717 \mathrm{~cm}^{-1}\right)$ and hydroxy $\left(v_{\max } 3445 \mathrm{~cm}^{-1}\right)$ groups. The direct connectivity between each proton and carbon was confirmed by the ${ }^{1} \mathrm{H},{ }^{13} \mathrm{C}$ and HSQC NMR spectral analysis (Table S9). ${ }^{1} \mathrm{H}$ and ${ }^{13} \mathrm{C}$ NMR spectra were similar to those of $\mathbf{1}$, excluding the absence of peaks of an oxymethine and an olefin. The COSY correlations from $\mathrm{H}-2$ to $\mathrm{H}-9$ and from $\mathrm{H}-19$ to $\mathrm{H}-22$ indicated the partial structures at C-2-C-9 and C-19-C-22 and the HMBC correlations at H-2 and H-21/C-1 showed the connectivity of $\mathrm{C}-1$ and $\mathrm{C}-21$ through the ester linkage. Based on the chemical formula, the remaining nine methylene carbons were set between C-10 and C-18. The $E$ geometries of $\Delta_{2,3}$ and $\Delta_{6,7}$ were characterized by $J$ values of $\mathrm{H}-2 / \mathrm{H}-3(J=15.7 \mathrm{~Hz})$ and $\mathrm{H}-6 / \mathrm{H}-7(15.4 \mathrm{~Hz})$, respectively. Thus, the planal structure of 5 was determined as depicted in Figure 3. 


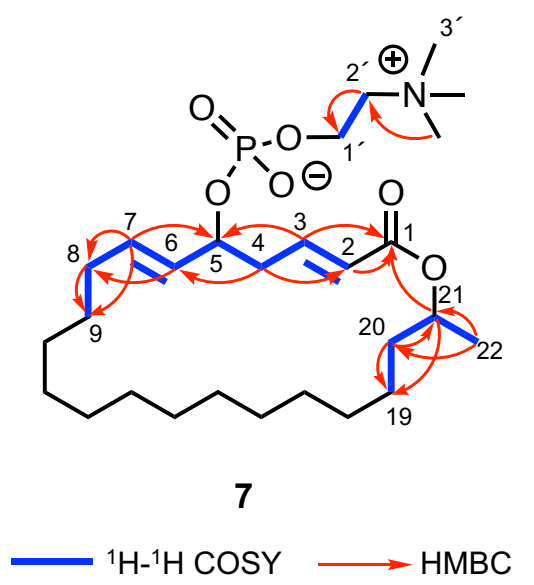

CIML C (7) had a molecular formula of $\mathrm{C}_{27} \mathrm{H}_{50} \mathrm{NO}_{6} \mathrm{P}$, as indicated by its negative HRESIMS $(\mathrm{m} / \mathrm{z}$ $538.3278[\mathrm{M}+\mathrm{Na}]^{+}$, calcd 538.3279). The direct connectivity between each proton and carbon was established by the HSQC spectrum (Table S9). Comparing the ${ }^{1} \mathrm{H}$ and ${ }^{13} \mathrm{C}$ NMR spectra, the overall macrolide skeleton of $\mathbf{7}$ was the same as that of $\mathbf{5}$, except for the presence of an oxymethine $\left(\delta_{\mathrm{H}} 4.22, \mathrm{~m}\right.$, $\left.\mathrm{H}_{2}-1^{\prime}\right)$, an aminomethylene ( $\left.\delta_{\mathrm{H}} 3.60, \mathrm{~m}, \mathrm{H}_{2}-2^{\prime}\right)$ and aminomethyl $\left(\delta_{\mathrm{H}} 3.20\right.$, brs, $\left.\mathrm{H}_{9}-3^{\prime}\right)$ protons. The COSY correlation between the oxymethine and aminomethylene protons and $\mathrm{HMBC}$ correlation at $\mathrm{H}-3^{\prime} / \mathrm{C}-2^{\prime}$ showed the presence of an trimethylethanolamine moiety. From the difference of the molecular weights between 5 and 7 (166 mass units), and the putative function of introduced modifying enzyme (transferring a phosphoethanolamine derivative), 7 was suggested to have a phosphocholine moiety at C-5 or C-9. The doublet signals of the carbons at C-5 $\left(\delta_{\mathrm{C}} 76.6,{ }^{2} J_{\mathrm{C}-5, \mathrm{P}}=6.5 \mathrm{~Hz}\right)$ and C-1' $\left(\delta_{\mathrm{C}} 62.8,{ }^{2} J_{\mathrm{C}-1^{\prime}, \mathrm{P}}=4.8 \mathrm{~Hz}\right)$, and the adjacent carbons (C-4: $\left.\delta_{\mathrm{C}} 40.2,{ }^{3} J_{\mathrm{C}-4, \mathrm{P}}=4.7 \mathrm{~Hz} ; \mathrm{C}-6: \delta_{\mathrm{C}} 133.0,{ }^{3} J_{\mathrm{C}-6, \mathrm{P}}=4.8 \mathrm{~Hz} ; \mathrm{C}-2^{\prime}: \delta_{\mathrm{C}} 41.7,{ }^{3} J_{\mathrm{C}-2^{\prime}, \mathrm{P}}=6.3 \mathrm{~Hz}\right)$ showed that the $\mathrm{C}-5$ and $\mathrm{C}-1^{\prime}$ were connected through a phosphate ester bond. Based on the chemical formula, the remaining nine methylene carbons were set between C-10 and C-18. The $E$ geometries of $\Delta_{2,3}$ and $\Delta_{6,7}$ were determined by $J$ values of H-2/H-3 $(J=15.7 \mathrm{~Hz})$ and H-6/H-7 $(J=15.5 \mathrm{~Hz})$, respectively. From the results above, 3 was indicated to be a 24-membered macrolide harboring phosphoethanolamine moiety at $\mathrm{C}-5$ of $\mathbf{1}$. 


\section{Isolation of CIML B (6)}

AO-cimlABD was cultivated in CPS medium $(300 \mathrm{~mL} ; 150 \mathrm{~mL}$ x 2$)$ at $30^{\circ} \mathrm{C}$ for 5 days. The cultured broth was extracted with EtOAc twice. The EtOAc extracts $(68 \mathrm{mg})$ were obtained. The extracts $(68 \mathrm{mg})$ was subjected to flash silica gel column chromatography eluted with $n$-hexane-EtOAc (3/1-1/2) to give 6 (21 mg).

CIML B (6): Colorless amorphous, Chemical formula $\mathrm{C}_{22} \mathrm{H}_{38} \mathrm{O}_{5}$, HRESIMS: $\mathrm{m} / z 405.2618[\mathrm{M}+\mathrm{Na}]^{+}$ (405.2611 calcd. for $\mathrm{C}_{22} \mathrm{H}_{38} \mathrm{O}_{5} \mathrm{Na}$ ), [ $\left.\alpha\right]_{\mathrm{D}}^{21}-9.9$ (c 0.73, EtOH); UV (EtOH) $\lambda_{\max } \mathrm{nm}$ (log $\varepsilon$ ) 206 (4.14); IR $(\mathrm{KBr}) v_{\max }\left(\mathrm{cm}^{-1}\right) 3421,2926,2854,1716,1654,1458,1271,1175,983,911$.

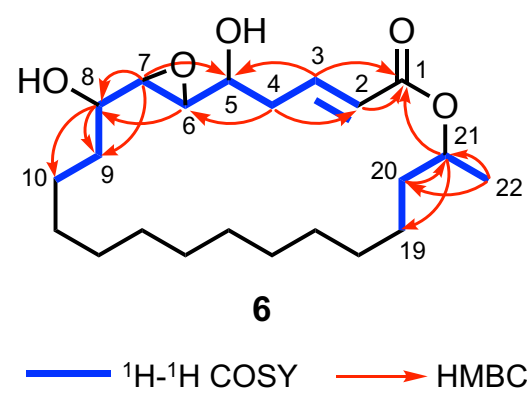

CIML B (6) had a molecular formula of $\mathrm{C}_{22} \mathrm{H}_{38} \mathrm{O}_{5}$, as indicated by its positive HRESIMS ( $\mathrm{m} / z$ 405.2618 $[\mathrm{M}+\mathrm{Na}]^{+}$, calcd 405.2611), implying four degrees of unsaturation. The ${ }^{1} \mathrm{H}$ and ${ }^{13} \mathrm{C}$ NMR spectra of 6 shows similar patterns to those of $\mathbf{5}$, except for the existence of characteristic epoxide peaks at $\delta_{\mathrm{H}} 2.88$ (dd, 6.5, 2.2, H-6), 2.83 (dt, 7.1, 2.2, H-7) and $\delta_{\mathrm{C}} 60.6(\mathrm{C}-6), 61.1$ (C-7) instead of olefin signals of 5 , and additional oxymethine peaks at $\delta_{\mathrm{H}} 3.26(\mathrm{dt}, 7.1,6.8, \mathrm{H}-8)$ and $\delta_{\mathrm{C}} 73.5(\mathrm{C}-8)$. Based on the chemical formula, the remaining eight methylene carbons were set between $\mathrm{C}-11$ and $\mathrm{C}-18$. The relative stereochemistry of the epoxide ring at C-6 and C-7 was determined as trans from its $J$ values of $\mathrm{H}-6 / \mathrm{H}-7$ ( $J=2.2 \mathrm{~Hz})$. The geochemistry of the olefin at C-s was determined as trans from its $J$ values of $\mathrm{H}-2 / \mathrm{H}-3(J=15.6 \mathrm{~Hz})$. From the above and corresponding 2D NMR correlations, we determined the plane structure of 2 (Table S9). 


\section{Isolation of CIML D (8)}

AO-cimlABCD was cultivated in CPS medium $(6 \mathrm{~L} ; 150 \mathrm{~mL}$ x 40$)$ at $30^{\circ} \mathrm{C}$ for 5 days. The cultured mycelia were harvested, freeze-dried, crushed to powder and extracted with $\mathrm{MeOH}$ twice. The $\mathrm{MeOH}$ solution was separated with $n$-hexane, and the $\mathrm{MeOH}$ extracts $(980 \mathrm{mg}$ ) were obtained. The extracts ( 980 $\mathrm{mg}$ ) were subjected to reversed-phase silica gel column chromatography eluted with $\mathrm{MeOH}$-water (6/19/1) to give mixture $\mathbf{8}$. The mixture $\mathbf{8}$ was separated by reversed-phase preparative TLC $(\mathrm{MeOH}$ : water $=$ $9: 1 \times 2)$ to afford $8(16 \mathrm{mg})$.

CIML D (8): Colorless amorphous, Chemical formula $\mathrm{C}_{27} \mathrm{H}_{51} \mathrm{NO}_{8} \mathrm{P}$, HRESIMS: $m / z 570.3173[\mathrm{M}+\mathrm{Na}]^{+}$ (570.3166 calcd. for $\mathrm{C}_{27} \mathrm{H}_{50} \mathrm{NO}_{8} \mathrm{P}$ ), $[\alpha]_{\mathrm{D}}^{22} 12.6$ (c 0.72, MeOH); UV (EtOH) $\lambda_{\max } \mathrm{nm}$ (log $\left.\varepsilon\right) 208$ (4.14); IR $(\mathrm{KBr})$ unmeasurable because of the solubility to several organic solvents.

\section{D structure determination of CIML D (8)}

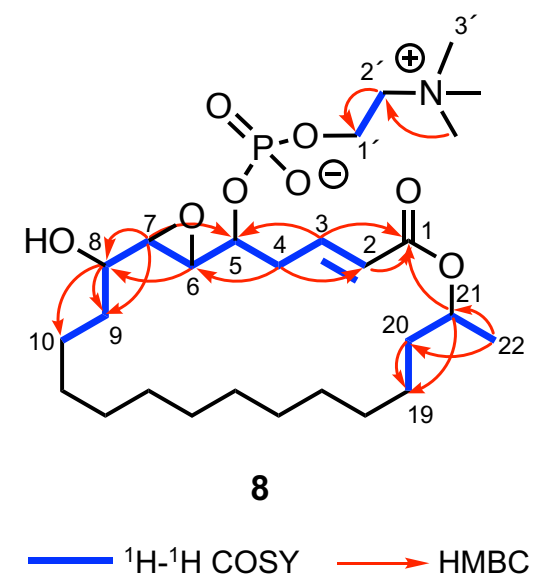

CIML D (8) had a molecular formula of $\mathrm{C}_{27} \mathrm{H}_{50} \mathrm{NO}_{8} \mathrm{P}$, as indicated by its negative HRESIMS $(\mathrm{m} / z$ $570.3173[\mathrm{M}+\mathrm{Na}]^{+}$, calcd 570.3166). All protons and carbons are assigned based on 1D and several 2D NMR spectra analysis (Table S9), showing that the macrolide backbone of 8 was same as 5-7. Comparing the ${ }^{1} \mathrm{H}$ and ${ }^{13} \mathrm{C}$ NMR spectra of 8 with those of 6 and 7, the existence of an epoxide at C-6 and C-7 ( $\delta_{\mathrm{H}}$ 3.02 (dd, 7.6, 2.1, H-6), 2.83 (dd, 6.5, 2.1, H-7) and $\delta_{\mathrm{C}} 58.1$ (C-6), 60.4 (C-7)) and a phosphocholine moiety was indicated. The relative stereochemistry of the epoxide was determined as trans from its $J$ values of $\mathrm{H}-6 / \mathrm{H}-7(J=2.1 \mathrm{~Hz})$. The phosphocholine residue was indicated to attach at $\mathrm{C}-5$ as the same as 7 by the observation of doublet signals of the carbons at C- $5\left(\delta_{\mathrm{C}} 75.6,{ }^{2} J_{\mathrm{C}-5, \mathrm{P}}=5.5 \mathrm{~Hz}\right)$ and $\mathrm{C}-1^{\prime}\left(\delta_{\mathrm{C}} 58.8\right.$, ${ }^{2} J_{\mathrm{C}-1^{\prime}, \mathrm{P}}=5.0 \mathrm{~Hz}$ ), and the adjacent carbons (C-4: $\delta_{\mathrm{C}} 36.1$, brd; C-6: $\delta_{\mathrm{C}} 58.1,{ }^{3} J_{\mathrm{C}-6, \mathrm{P}}=6.0 \mathrm{~Hz} ; \mathrm{C}-2^{\prime}: \delta_{\mathrm{C}} 66.5$, brd). Based on the chemical formula, the remaining eight methylene carbons were set between $\mathrm{C}-11$ and C-18. The geochemistry of the olefin at C-2 was established as trans from its $J$ values of $\mathrm{H}-2 / \mathrm{H}-3(J=$ 15.7 Hz). From these data, we decided the 2D-structure of 8 as shown (Figure 3). 
Table S9. ${ }^{13} \mathrm{C}(125 \mathrm{MHz})$ and ${ }^{1} \mathrm{H}(500 \mathrm{MHz})$ NMR data for CIMLs A-D (5-8) ${ }^{a}$.

\begin{tabular}{|c|c|c|c|c|c|c|c|c|}
\hline \multicolumn{3}{|c|}{ CIML A $(5)^{b}$} & \multicolumn{2}{|c|}{ CIML B $(6)^{c}$} & \multicolumn{2}{|c|}{ CIML C $(7)^{c}$} & \multicolumn{2}{|c|}{ CIML D $(8)^{d}$} \\
\hline Position & ${ }^{13} \mathrm{C}$ & ${ }^{\mathrm{T}} \mathrm{H}$ (multi, $J$ in $\mathrm{Hz}$ ) & ${ }^{13} \mathrm{C}$ & ${ }^{\mathrm{T}} \mathrm{H}$ (multi, $J$ in $\left.\mathrm{Hz}\right)$ & ${ }^{13} \mathrm{C}$ & ${ }^{\top} \mathrm{H}$ (multi, $J$ in $\left.\mathrm{Hz}\right)$ & ${ }^{13} \mathrm{C}$ & ${ }^{\mathrm{T}} \mathrm{H}$ (multi, $J$ in $\left.\mathrm{Hz}\right)$ \\
\hline 1 & 165.8 & & 167.5 & & 167.5 & & 166.1 & \\
\hline 2 & 124.5 & $5.85(1 \mathrm{H}, \mathrm{d}, 15.7)$ & 125.4 & $5.94(1 \mathrm{H}, \mathrm{dt}, 15.6,1.4)$ & 125.3 & $5.88(1 \mathrm{H}, \mathrm{d}, 15.7)$ & 124.7 & $5.95(1 \mathrm{H}, \mathrm{d}, 15.7)$ \\
\hline 3 & 143.8 & $6.90(1 \mathrm{H}, \mathrm{dt}, 15.7,7.4)$ & 145.3 & $7.02(1 \mathrm{H}, \mathrm{dt}, 15.6,7.5)$ & 145.4 & $6.94(1 \mathrm{H}, \mathrm{dt}, 15.7,7.4)$ & 142.4 & $7.00(1 \mathrm{H}, \mathrm{dt}, 15.7,7.5)$ \\
\hline 4 & 39.7 & $2.50(2 \mathrm{H}, \mathrm{m})$ & 38.3 & $2.53(2 \mathrm{H}, \mathrm{m})$ & 40.0 & $2.59(1 \mathrm{H}, \mathrm{m})$ & 36.1 & $2.65(1 \mathrm{H}, \mathrm{m})$ \\
\hline 5 & 71.6 & $4.28(1 \mathrm{H}, \mathrm{m})$ & 72.1 & $3.48(1 \mathrm{H}, \mathrm{m})$ & 76.4 & $\begin{array}{l}2.69(1 \mathrm{H}, \mathrm{m}) \\
4.74(1 \mathrm{H}, \mathrm{m})\end{array}$ & 75.6 & $\begin{array}{l}2.77(1 \mathrm{H}, \mathrm{m}) \\
3.93(1 \mathrm{H}, \mathrm{m})\end{array}$ \\
\hline 6 & 131.2 & $5.47(1 \mathrm{H}, \mathrm{dd}, 15.4,7.2)$ & 60.6 & $2.88(1 \mathrm{H}, \mathrm{dd}, 6.5,2.2)$ & 130.6 & $5.46(1 \mathrm{H}, \mathrm{dd}, 15.2,6.9)$ & 58.1 & $3.02(1 \mathrm{H}, \mathrm{dd}, 7.6,2.1)$ \\
\hline 7 & 133.6 & $5.68(1 \mathrm{H}, \mathrm{dt}, 15.4,7.0)$ & 61.1 & $2.83(1 \mathrm{H}, \mathrm{dt}, 7.1,2.2)$ & 134.6 & $5.75(1 \mathrm{H}, \mathrm{dt}, 15.2,7.2)$ & 60.4 & $2.83(1 \mathrm{H}, \mathrm{dd}, 6.5,2.1)$ \\
\hline 8 & 31.7 & $2.04(2 \mathrm{H}, \mathrm{m})$ & 73.5 & $3.26(1 \mathrm{H}, \mathrm{dt}, 7.1,6.8)$ & 32.8 & $2.05(2 \mathrm{H}, \mathrm{m})$ & 71.1 & $3.29(1 \mathrm{H}, \mathrm{m})$ \\
\hline 9 & 28.4 & $1.37(2 \mathrm{H}, \mathrm{m})$ & 35.3 & $1.56(2 \mathrm{H}, \mathrm{m})$ & 29.6 & $1.39(2 \mathrm{H}, \mathrm{m})$ & 33.7 & $1.47(1 \mathrm{H}, \mathrm{m})$ \\
\hline 10 & $27.5^{e}$ & & 25.7 & $1.40(2 \mathrm{H}, \mathrm{m})$ & $28.57^{g}$ & & 24.7 & $1.40(2 \mathrm{H}, \mathrm{m})$ \\
\hline 11 & $27.7^{e}$ & & $29.1^{f}$ & & $28.59^{g}$ & & $27.2^{h}$ & \\
\hline 12 & $27.76^{e}$ & & $29.2^{f}$ & & $28.7^{g}$ & & $27.4^{h}$ & \\
\hline 13 & $27.83^{e}$ & & $29.3^{f}$ & & $28.9^{g}$ & & $27.5^{h}$ & \\
\hline 14 & $27.99^{e}$ & $1.27-1.36(18 \mathrm{H})$ & $29.4^{t}$ & $128136(16 \mathrm{H})$ & $28.9^{g}$ & $1.32-1.36(18 \mathrm{H})$ & $27.7^{h}$ & \\
\hline 15 & $28.00^{e}$ & & $29.5^{f}$ & $1.28-1.36(16 \mathrm{H})$ & $29.16^{g}$ & & $27.7^{h}$ & $1.21-1.29(16 \mathrm{H})$ \\
\hline 16 & $28.04^{e}$ & & $29.7^{f}$ & & $29.21^{g}$ & & $27.8^{h}$ & \\
\hline 17 & $28.1^{e}$ & & $29.9^{f}$ & & $29.24^{g}$ & & $28.3^{h}$ & \\
\hline 18 & $28.3^{e}$ & & $30.1^{f}$ & & $29.3^{g}$ & & $28.7^{h}$ & \\
\hline 19 & 24.8 & $1.33(2 \mathrm{H}, \mathrm{m})$ & 25.9 & $1.40(2 \mathrm{H}, \mathrm{m})$ & 25.8 & $1.34(2 \mathrm{H}, \mathrm{m})$ & 24.3 & $1.34(2 \mathrm{H}, \mathrm{m})$ \\
\hline 20 & 35.6 & $1.50(1 \mathrm{H}, \mathrm{m})$ & 36.2 & $1.60(1 \mathrm{H}, \mathrm{m})$ & 36.5 & $1.51(1 \mathrm{H}, \mathrm{m})$ & 35.1 & $1.51(1 \mathrm{H}, \mathrm{m})$ \\
\hline & & $1.61(1 \mathrm{H}, \mathrm{m})$ & & $1.66(1 \mathrm{H}, \mathrm{m})$ & & $1.61(1 \mathrm{H}, \mathrm{m})$ & & $1.61(1 \mathrm{H}, \mathrm{m})$ \\
\hline 21 & 70.7 & $4.99(1 \mathrm{H}, \mathrm{m})$ & 72.4 & $4.99(1 \mathrm{H}, \mathrm{m})$ & 71.8 & $4.96(1 \mathrm{H}, \mathrm{m})$ & 71.1 & $4.98(1 \mathrm{H}, \mathrm{m})$ \\
\hline 22 & 20.1 & $1.23(3 \mathrm{H}, \mathrm{d}, 6.3)$ & 20.4 & $1.23(3 \mathrm{H}, \mathrm{d}, 6.3)$ & 20.4 & $1.21(3 \mathrm{H}, \mathrm{d}, 6.3)$ & 19.8 & $1.23(3 \mathrm{H}, \mathrm{d}, 6.3)$ \\
\hline $1^{\prime}$ & & & & & 60.3 & $4.22(2 \mathrm{H}, \mathrm{m})$ & 58.8 & $4.30(2 \mathrm{H}, \mathrm{m})$ \\
\hline $2^{\prime}$, & & & & & 67.4 & $3.60(2 \mathrm{H}, \mathrm{m})$ & 66.5 & $3.64(2 \mathrm{H}, \mathrm{m})$ \\
\hline $3^{\prime}$ & & & & & 54.7 & 3.20 (9H, brs) & 54.1 & 3.22 (9H, brs) \\
\hline
\end{tabular}

[a] Assignments were based on ${ }^{1} \mathrm{H}^{-1} \mathrm{H}$ COSY, HSQC and HMBC experiments.

[b] Recorded in $\mathrm{CDCl}_{3}$. $[c]$ Recorded in $\mathrm{CD}_{3} \mathrm{OD}$. [d] Recorded in $\mathrm{CDCl}_{3}\left(20 \% \mathrm{CD}_{3} \mathrm{OD}\right)$. [e- $\left.h\right]$ Interchangeable. 


\section{Determination of the absolute configurations of CIMLs A-D (5-8)}

CIMLs A-D (5-8) have chiral centers at C-5 and C-21 and $\mathbf{6}$ and 8 have additional three ones at C-6, C7 and C-8. To determine the absolute configurations at C-5 and C-21, 5 was used for chemical derivatization and the advanced Mosher's method (Figure S5A) and $\mathbf{8}$ was conducted the advanced Mosher's method for C-8 (Figure S5B). The stereochemistry at C-6 and C-7 was established by NMR calculation of $\mathbf{6}$ as well as $\mathbf{2}$ (Table S12). The remaining all absolute configurations of 5-8 were determined to be the same as 5, $\mathbf{6}$ and $\mathbf{8}$ from the point of view of biosynthesis.

Compound 5 was converted to MTPA derivatives 18a and $18 \mathrm{~b}$ and their $\Delta \delta_{\mathrm{H}(S-R)}$ values showed their configurations as $S$ at $\mathrm{C}-5$ and $R$ at C-21 of 5 (Figure S5A). As the same manner, the stereochemistry at C-8 of $\mathbf{8}$ was determined as $S$ (Figure S5B). The trans conformer of the epoxide of $\mathbf{6}$ was characterized by its $J$ values of H-6/H-7 $(J=2.2 \mathrm{~Hz})$. The configuration of epoxide moiety relative to C-5 and C-8 was determined by GIAO 13C NMR calculations and DP4 analysis (Table S12). From these results above, the absolute configuration of CIMLs A-D (5-8) were established as depicted below.

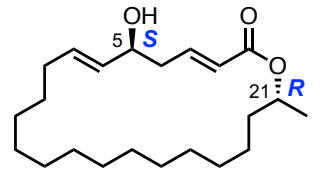

CIML A (5)

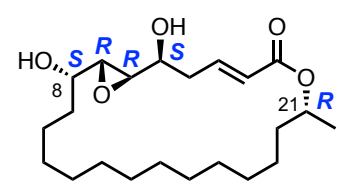

CIML B (6)

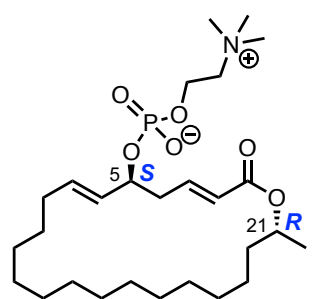

CIML C (7)

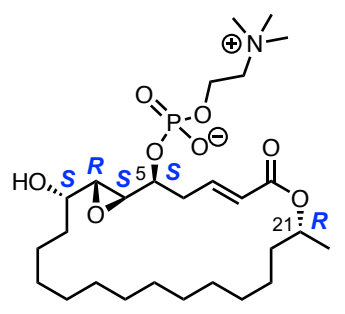

CIML D (8)

(A) Determination of absolute configuration at C-5 and C-21 of 5
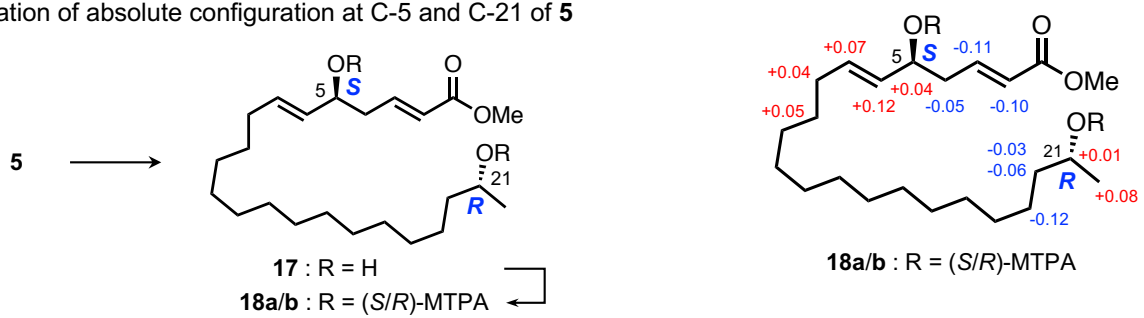

(B) Determination of absolute configuration at C-8 of 8
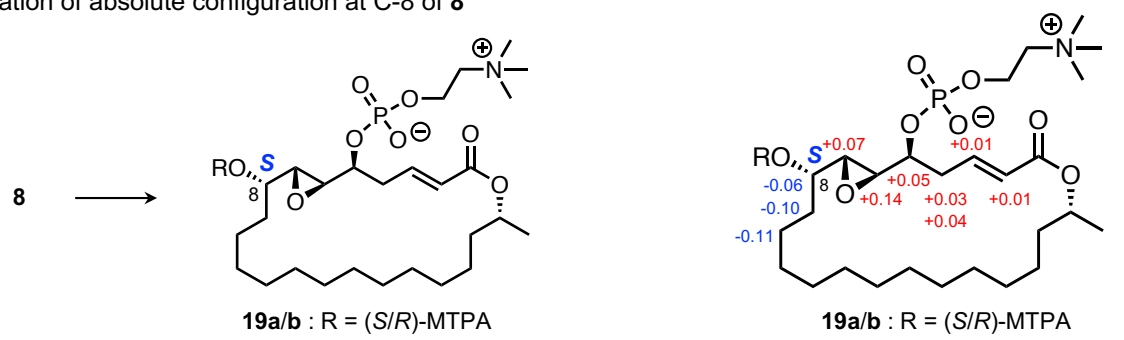

Figure S5. Determination of absolute configurations of CIMLs A-D. Schemes for determining absolute configurations at (A) C-5 and C-21 of 5 and (B) C-8 of 2. The $\Delta \delta_{\mathrm{H}(S-R)}$ values (parts per million) of 18a and $18 \mathrm{~b}$, and 19a and $19 \mathrm{~b}$ were shown in red or blue. 


\section{Synthesis of 17}<smiles>CO[C@@H](C)CCCCCCCCCCCCC/C=C/C(O)C/C=C/C(=O)O</smiles>

CIML A (5)<smiles>C[C@H](O)CCCCCCCCCCCCC/C=C/[C@H](O)/C=C/C=C/C(=O)O</smiles>

16

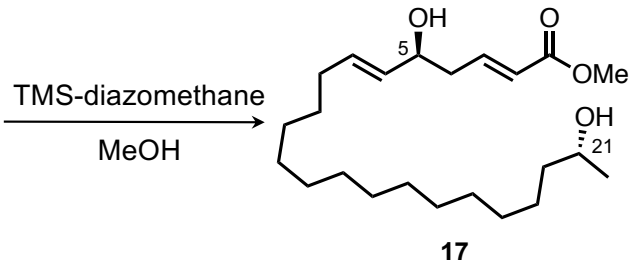

17

CIML A (5) (4.0 mg, $11.4 \mu \mathrm{mol})$ was dissolved in $150 \mu \mathrm{L}$ 1,2-DME and a $2 \mathrm{~N}$ aqueous LiOH solution $(150 \mu \mathrm{L})$ was added, and the reaction was stirred for $24 \mathrm{~h}$ at room temperature. To the reaction mixture was added $1 \mathrm{~N}$ aqueous $\mathrm{HCl}$ solution $(c a .320 \mu \mathrm{L})(\mathrm{pH}$ of the aqueous layer $<2)$ and extracted with EtOAc (x5) and concentrated in vacuo. The crude 16 (4.2 $\mathrm{mg})$ were subjected to a flash silica gel column chromatography eluted with $\mathrm{CHCl}_{3}-\mathrm{MeOH}(40 / 1)$ to give 16 (3.2 mg). HRESIMS analysis of the extract showed the presence of pure $16(\mathrm{~m} / z \text { 367.2851 [M-H] }]^{-}$, calcd. 367.2854).

To a solution of $16(1.6 \mathrm{mg}, 4.3 \mu \mathrm{mol})$ in $30 \mu \mathrm{L} \mathrm{MeOH}, 40 \mu \mathrm{L}$ TMS-diazomethane (ca. $0.6 \mathrm{~mol} / \mathrm{L}, 24$ $\mu \mathrm{mol})$ was added, and the reaction was incubated for $1 \mathrm{~h}$ at room temperature. The reaction mixture was concentrated in vacuo. The crude $17(1.7 \mathrm{mg})$ were subjected to a flash silica gel column chromatography eluted with $\mathrm{CHCl}_{3}-\mathrm{MeOH}(40 / 1)$ to give $17(0.8 \mathrm{mg})$. HRESIMS analysis showed the presence of $17(\mathrm{~m} / z$ 405.2980 [M+Na $]^{+}$, calcd. 405.2986).

Compound 17: Colorless amorphous, HRESIMS: $m / z 405.2980[\mathrm{M}+\mathrm{Na}]^{+} 405.2986$ calcd. for $\mathrm{C}_{23} \mathrm{H}_{42} \mathrm{O}_{4} \mathrm{Na}$ ), all protons and carbons were assigned as Table $\mathrm{S} 10$.

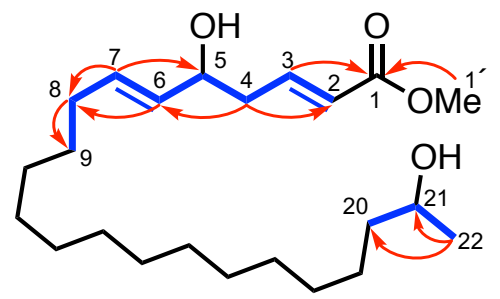

\section{Table S10. ${ }^{13} \mathrm{C}(125 \mathrm{MHz})$ and ${ }^{1} \mathrm{H}(500 \mathrm{MHz})$ NMR data for $17^{a, b}$.}

\begin{tabular}{lrl}
\hline $\mathbf{1 7}$ & & \\
\hline Position & \multicolumn{1}{c}{$\mathrm{C} \mathrm{C}$} & ${ }^{\mathrm{T}} \mathrm{H}$ (multi, $J$ in $\left.\mathrm{Hz}\right)$ \\
\hline 1 & 166.7 & \\
2 & 123.4 & $5.91(1 \mathrm{H}, \mathrm{dt}, 9.8,1.8)$ \\
3 & 145.0 & $6.96(1 \mathrm{H}, \mathrm{dt}, 9.8,4.2)$ \\
4 & 40.1 & $2.44(2 \mathrm{H}, \mathrm{m})$ \\
5 & 71.6 & $4.22(1 \mathrm{H}, \mathrm{m})$ \\
6 & 131.5 & $5.48(1 \mathrm{H}, \mathrm{dd}, 15.5,6.4)$ \\
7 & 133.3 & $5.69(1 \mathrm{H}, \mathrm{m})$ \\
8 & 32.1 & $2.03(1 \mathrm{H}, \mathrm{ddd}, 14.3,7.5,7.5)$ \\
9 & 29.0 & $1.36(1 \mathrm{H}, \mathrm{m})$ \\
10 & $25.8^{c}$ & $1.29(1 \mathrm{H}, \mathrm{m})$ \\
& & $1.39(1 \mathrm{H}, \mathrm{m})$ \\
11 & $29.1^{c}$ & \\
12 & $29.5^{c}$ & \\
13 & $29.5^{c}$ & \\
14 & $29.6^{c}$ & \\
15 & $29.6^{c}$ & $1.22-1.38(18 \mathrm{H}, \mathrm{m})$ \\
16 & $29.6^{c}$ & \\
17 & $29.6^{c}$ & \\
18 & $29.6^{c}$ & \\
19 & $29.6^{c}$ & \\
20 & 39.4 & $1.43(2 \mathrm{H}, \mathrm{m})$ \\
21 & $68.2^{2}$ & $3.80(1 \mathrm{H}, \mathrm{m})$ \\
22 & 23.5 & $1.19(3 \mathrm{H}, \mathrm{d}, 6.2)$ \\
$1^{\prime}$ & 51.5 & $3.73(3 \mathrm{H}, \mathrm{s})$ \\
\hline
\end{tabular}

[a] Assignments were based on ${ }^{1} \mathrm{H}-{ }^{1} \mathrm{H}$ COSY, HSQC and $\mathrm{HMBC}$ experiments.

[b] Recorded in $\mathrm{CDCl}_{3}$. [c] Interchangeable. 


\section{Synthesis of $18 a / b$}
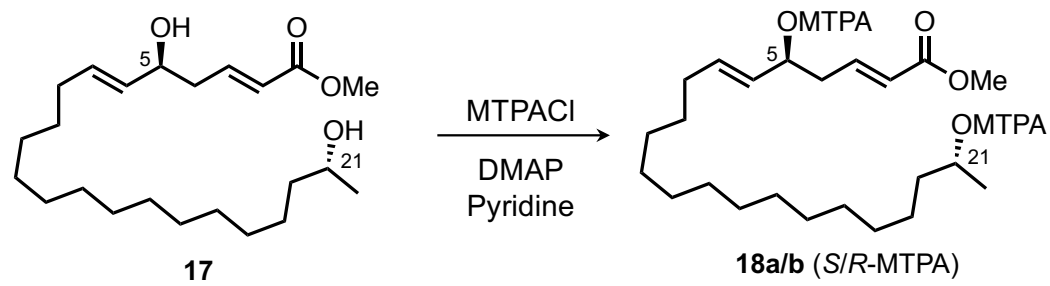

For the preparation of the $(S)$-MTPA ester, $17(0.4 \mathrm{mg}, 1.0 \mu \mathrm{mol})$ was dissolved in pyridine and $(R)$ MTPA chloride $(5 \mu \mathrm{L}, 14.6 \mu \mathrm{mol})$ was added. The mixture was stirred at room temperature for $3 \mathrm{~h}$ and then $0.1 \mathrm{M} \mathrm{HCl}$ solution were added. The water layer was extracted with EtOAc (x5) and concentrated in vacuo. The resulting mixture $(12.8 \mathrm{mg})$ were subjected to a flash silica gel column chromatography eluted with $\mathrm{CHCl}_{3}-\mathrm{MeOH}(40 / 1)$ to give $(S)$-MTPA ester 18a $(0.6 \mathrm{mg})$. The $(R)$-MTPA ester $\mathbf{1 8 b}(1.2 \mathrm{mg})$ was prepared in the same manner by the addition of $(S)$-MTPA chloride $(2 \mu \mathrm{L}, 5.8 \mu \mathrm{mol})$. The complete assignment of all protons was achieved using ${ }^{1} \mathrm{H}^{-1} \mathrm{H}$ COSY experiment and comparing ${ }^{1} \mathrm{H}$ NMR of 18a and $\mathbf{1 8 b}$.

Compound 18a: Colorless amorphous, HRESIMS: $m / z$ 837.3777 $[\mathrm{M}+\mathrm{Na}]^{+}$(837.3783 calcd. for $\left.\mathrm{C}_{43} \mathrm{H}_{56} \mathrm{~F}_{6} \mathrm{O}_{8} \mathrm{Na}\right),{ }^{1} \mathrm{H}$ NMR $\left(500 \mathrm{MHz}, \mathrm{CDCl}_{3}\right) ; \delta=6.75$ (dt, 15.7, 7.3, H-3), 5.89 (dt, 15.2, 7.0, H-7), 5.79 (d, 15.7, H-2), 5.56 (m, H-5), 5.46 (dd, 15.2, 8.0, H-6), 5.15 (m, H-21), 2.54 (m, H-4), 2.05 (m, H-8), 1.61 (m, Ha-20), 1.50 (m, Hb-20), 1.38 (m, H-9), 1.33 (d, 6.3, H-22), 1.19 (m, H-19), 1.17-1.38 (m, 18H).

Compound 18b: Colorless amorphous, HRESIMS: $m / z$ 837.3784 $[\mathrm{M}+\mathrm{Na}]^{+}$(837.3783 calcd. for $\left.\mathrm{C}_{43} \mathrm{H}_{56} \mathrm{~F}_{6} \mathrm{O}_{8} \mathrm{Na}\right),{ }^{1} \mathrm{H}$ NMR $\left(500 \mathrm{MHz}, \mathrm{CDCl}_{3}\right) ; \delta=6.86$ (dt, 15.7, 7.3, H-3), 5.89 (d, 15.7, H-2), 5.82 (dt, 15.4, 7.9, H-7), 5.52 (m, H-5), 5.34 (dd, 15.4, 7.7, H-6), 5.14 (m, H-21), 2.59 (m, H-4), 2.01 (m, H-8), 1.67 (m, Ha-20), 1.53 (m, Hb-20), 1.33 (m, H-9), 1.31 (m, H-19), 1.25 (m, H-22), 1.19-1.37 (m, 18H).

\section{Synthesis of $19 a / b$}

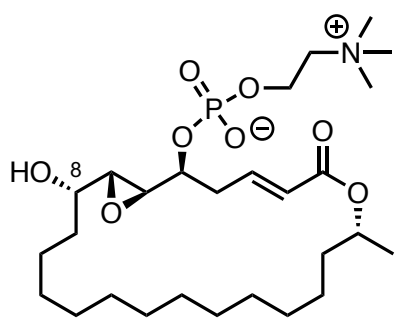

CIML D (8)

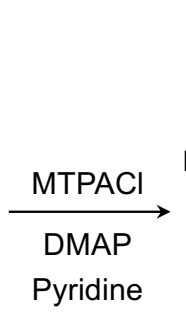

yridine

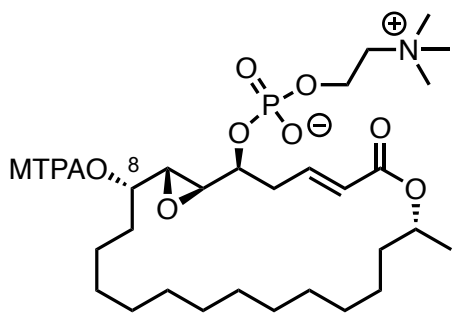

19a/b (S/R-MTPA)

For the preparation of the $(S)$-MTPA ester, $8(0.4 \mathrm{mg}, 0.7 \mu \mathrm{mol})$ and DMAP (cat.) were dissolved in 30 $\mu \mathrm{L}$ pyridine and $(R)$-MTPA chloride $(1.5 \mu \mathrm{L}, 4.4 \mu \mathrm{mol})$ was added. The mixture was stirred at room temperature for $3 \mathrm{~h}$ and then water was added. The water layer was extracted with EtOAc (x5) and concentrated in vacuo. The resulting mixture $(6.5 \mathrm{mg})$ were subjected to a reverse-phase column chromatography eluted with $\mathrm{MeOH}$-water (6/1-9/1) to give (S)-MTPA ester 19a $(0.3 \mathrm{mg})$. The $(R)$-MTPA ester $19 \mathrm{~b}(1.0 \mathrm{mg})$ was prepared in the same manner by the addition of $(S)$-MTPA chloride $(2 \mu \mathrm{L}, 5.8$ $\mu \mathrm{mol})$ without DMAP. The complete assignment of all protons was achieved using ${ }^{1} \mathrm{H}-{ }^{1} \mathrm{H}$ COSY experiment.

Compound 19a: Colorless amorphous, HRESIMS: $m / z 786.3580[\mathrm{M}+\mathrm{Na}]^{+} 786.3564$ calcd. for $\mathrm{C}_{37} \mathrm{H}_{56} \mathrm{~F}_{3} \mathrm{NO}_{10} \mathrm{Na}$ ), ${ }^{1} \mathrm{H}$ NMR (500 MHz, $\mathrm{CD}_{3} \mathrm{OD}$ ); $\delta=7.05$ (dt, 15.6, 7.5, H-3), 6.00 (d, 15.6, H-2), 4.99 (m, H-21), 4.87 (m, H-8), 3.96 (m, H-5), 3.24 (m, H-6), 3.21 (m, H-7), 2.77 (m, Ha-4), 2.69 (m, Hb-4), 1.67 (m, H $\left.\mathrm{H}_{2}-9\right), 1.63$ (m, Hb-20), 1.53 (m, Ha-20), 1.26 (m, H $\left.\mathrm{H}_{2}-10\right), 1.25-1.38$ (m, 18H), 1.22 (d, 6.3, $\mathrm{H}_{3}-$ 22). 
Compound 19b: Colorless amorphous, HRESIMS: $m / z 786.3575[\mathrm{M}+\mathrm{Na}]^{+} 786.3564$ calcd. for $\mathrm{C}_{37} \mathrm{H}_{56} \mathrm{~F}_{3} \mathrm{NO}_{10} \mathrm{Na}$ ), ${ }^{1} \mathrm{H}$ NMR (500 MHz, $\left.\mathrm{CD}_{3} \mathrm{OD}\right) ; \delta=7.04$ (dt, 15.6, 7.0, H-3), 5.99 (d, 15.6, H-2), 5.00 (m, H-21), 4.93 (m, H-8), 3.91 (m, H-5), 3.14 (dd, 6.9, 2.1, H-7), 3.10 (dd, 7.5, 2.1, H-6), 2.73 (m, Ha-4), 2.66 (m, Hb-4), 1.77 (m, H2-9), 1.64 (m, Hb-20), 1.53 (m, Ha-20), 1.37 (m, $\left.\mathrm{H}_{2}-10\right), 1.25-1.40$ (m, 18H), $1.23\left(\mathrm{~d}, 6.3, \mathrm{H}_{3}-22\right)$.

\section{GIAO 13C NMR calculations and DP4 analysis}

Akml B (2), epi-Akml B (20), Ciml B (6), epi-Ciml B (21) were constructed in silico and their stable conformers were generated by using CONFLEX 7 software.$^{54}$ Conformers within a $2.0 \mathrm{kcal} / \mathrm{mol}$ energy window from the most stable ones for each molecule were optimized using DFT/B3LYP/6$31 \mathrm{G}(\mathrm{d}, \mathrm{p}) / \mathrm{PCM}$ (methanol) on Gaussian 16 program. ${ }^{\mathrm{s} 5}$ Resultant stable conformers within $1.0 \mathrm{kcal} / \mathrm{mol}$ energy window for each molecule were submitted to GIAO ${ }^{13} \mathrm{C}$ NMR calculations using DFT/ $\omega \mathrm{B} 97 \mathrm{X}$ $\mathrm{D} / 6-31 \mathrm{G}(\mathrm{d}, \mathrm{p}) / \mathrm{PCM}$ (methaol). The calculated shielding constants for each conformer were averaged on the basis of its Boltzmann population. The predicted chemical shifts are presented by using the shielding constant of TMS calculated at the same level of theory as a reference $\left(\delta_{\mathrm{C}} 0.0\right)$. These numbers were submitted to the web applet developed by Goodman et al..$^{\mathrm{S} 6}$ to calculate DP4 probability.

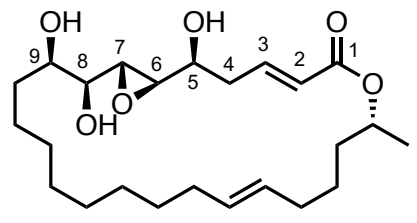

AKML B (2)

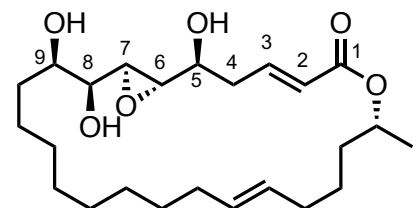

epi-AKML B (20)

\begin{tabular}{|l|l|l|l|}
\hline & obsd [ppt] & calcd for $\mathbf{2}$ & calcd for $\mathbf{2 0}$ \\
\hline C1 & 167.6 & 163.8 & 167.1 \\
\hline C2 & 125.2 & 121.9 & 121.0 \\
\hline C3 & 145.7 & 147.0 & 151.3 \\
\hline C4 & 38.1 & 37.7 & 36.1 \\
\hline C5 & 71.9 & 73.6 & 67.2 \\
\hline C6 & 60.8 & 62.6 & 57.0 \\
\hline C7 & 58.7 & 60.4 & 60.2 \\
\hline C8 & 76.9 & 78.9 & 73.1 \\
\hline C9 & 74.0 & 70.3 & 68.6 \\
\hline C10 & 33.6 & 35.2 & 35.7 \\
\hline C11 & 26.6 & 27.3 & 24.5 \\
\hline C12 & $29.3^{a}$ & 30.2 & 26.1 \\
\hline C13 & $30.0^{a}$ & 32.5 & 30.0 \\
\hline C14 & $30.2^{a}$ & 28.6 & 27.3 \\
\hline C15 & $30.4^{a}$ & 28.3 & 27.7 \\
\hline C16 & $30.4^{a}$ & 28.7 & 30.0 \\
\hline C17 & 33.1 & 32.2 & 33.6 \\
\hline C18 & 131.8 & 129.6 & 129.6 \\
\hline C19 & 131.4 & 130.3 & 130.0 \\
\hline C20 & 33.1 & 33.3 & 33.5 \\
\hline C21 & 26.4 & 26.7 & 25.0 \\
\hline C22 & 36.2 & 34.7 & 35.1 \\
\hline C23 & 72.4 & 72.3 & 20.3 \\
\hline C24 & 20.4 & $99.7 \%$ & $0.3 \%$ \\
\hline DP4 & & & \\
\hline & & 21.6 & 2.0 \\
\hline
\end{tabular}

Table S11. Comparison of the observed ${ }^{13} \mathrm{C}$ NMR chemical shift of $\mathbf{2}$ in $\mathrm{CDCl}_{3}$ and calculated values for 2 and 20 at DFT/ $\omega \mathrm{B} 97 \mathrm{X}-\mathrm{D} / 6-31 \mathrm{G}(\mathrm{d}, \mathrm{p}) / \mathrm{PCM}$ (methanol). The calculated values deviated from the observed ones for more than $3 \mathrm{ppm}$ are highlighted in yellow and $5 \mathrm{ppm}$ in red. The DP4 probability scores are shown in the bottom line. $a$; interchangeable. 


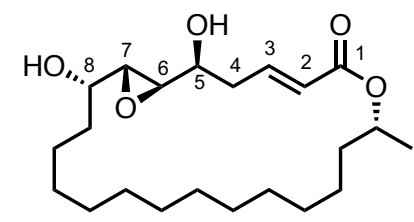

CIML B (6)

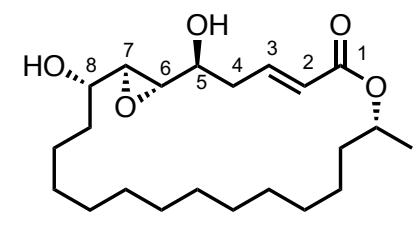

epi-CIML B (21)

\begin{tabular}{|l|l|l|l|}
\hline & obsd [ppt] & calcd for 6 & calcd for 21 \\
\hline C1 & 167.5 & 163.3 & 163.9 \\
\hline C2 & 125.4 & 123.7 & 121.9 \\
\hline C3 & 145.3 & 144.9 & 146.0 \\
\hline C4 & 38.3 & 41.2 & 35.9 \\
\hline C5 & 72.1 & 67.0 & 65.7 \\
\hline C6 & 60.6 & 60.5 & 57.3 \\
\hline C7 & 61.1 & 61.1 & 58.7 \\
\hline C8 & 73.5 & 73.2 & 68.1 \\
\hline C9 & 35.3 & 34.6 & 34.1 \\
\hline C10 & $25.7^{a}$ & 25.6 & 29.0 \\
\hline C11 & $29.1^{a}$ & 30.9 & 30.9 \\
\hline C12 & $29.2^{a}$ & 31.2 & 30.0 \\
\hline C13 & $29.3^{a}$ & 27.9 & 29.7 \\
\hline C14 & $29.4^{a}$ & 29.6 & 26.4 \\
\hline C15 & $29.5^{a}$ & 29.6 & 27.8 \\
\hline C16 & $29.7^{a}$ & 28.1 & 26.9 \\
\hline C17 & $29.9^{a}$ & 30.3 & 27.7 \\
\hline C18 & $30.1^{a}$ & 29.9 & 28.4 \\
\hline C19 & $25.9^{a}$ & 26.7 & 26.6 \\
\hline C20 & $36.2^{a}$ & 36.3 & 36.2 \\
\hline C21 & 72.4 & 70.0 & 71.6 \\
\hline C22 & 20.4 & 21.4 & 20.5 \\
\hline DP4 & & $100.0 \%$ & $0.0 \%$ \\
\hline & & & \\
\hline & & & \\
\hline & & & \\
\hline
\end{tabular}

Table S12. Comparison of the observed ${ }^{13} \mathrm{C}$ NMR chemical shift of 6 in $\mathrm{CDCl}_{3}$ and calculated values for

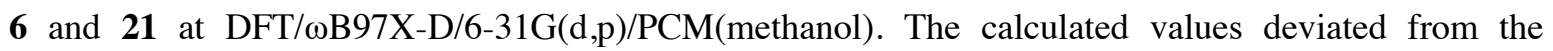
observed ones for more than $3 \mathrm{ppm}$ are highlighted in yellow and $5 \mathrm{ppm}$ in red. The DP4 probability scores are shown in the bottom line. $a$; interchangeable. 


\section{References}

S1 Jin, F. J.; Maruyama, J.; Juvvadi, P. R.; Arioka, M.; Kitamoto, K. Biosci., Biotechnol., Biochem. 2004, $68,656-662$.

S2 Bus, J; Frost D. J. Journal of the Royal Netherlands Chemical Society, 1974, 93, 213-215.

S3 Kozone, I.; Ueda, J.; Watanabe, M.; Nogami, S.; Nagai, A.; Inaba, S.; Ohya, Y.; Takagi, M.; Shin-ya, K. J. Antibiot. 2009, 62, 159-162.

S4 CONFLEX 7, Goto, H.; Obata, S.; Nakayama, N.; Ohta, K. CONFLEX Corporation, Tokyo, Japan, 2012.

S5 Gaussian 16, Revision A.03, Frisch, M. J.; Trucks, G. W.; Schlegel, H. B.; Scuseria, G. E.; Robb, M. A.; Cheeseman, J. R.; Scalmani, G.; Barone, V.; Petersson, G. A.; Nakatsuji, H.; Li, X.; Caricato, M.; Marenich, A. V.; Bloino, J.; Janesko, B. G.; Gomperts, R.; Mennucci, B.; Hratchian, H. P.; Ortiz, J. V.; Izmaylov, A. F.; Sonnenberg, J. L.; Williams-Young, D.; Ding, F.; Lipparini, F.; Egidi, F.; Goings, J.; Peng, B.; Petrone, A.; Henderson, T.; Ranasinghe, D.; Zakrzewski, V. G.; Gao, J.; Rega, N.; Zheng, G.; Liang, W.; Hada, M.; Ehara, M.; Toyota, K.; Fukuda, R.; Hasegawa, J.; Ishida, M.; Nakajima, T.; Honda, Y.; Kitao, O.; Nakai, H.; Vreven, T.; Throssell, K.; Montgomery, J. A., Jr.; Peralta, J. E.; Ogliaro, F.; Bearpark, M. J.; Heyd, J. J.; Brothers, E. N.; Kudin, K. N.; Staroverov, V. N.; Keith, T. A.; Kobayashi, R.; Normand, J.; Raghavachari, K.; Rendell, A. P.; Burant, J. C.; Iyengar, S. S.; Tomasi, J.; Cossi, M.; Millam, J. M.; Klene, M.; Adamo, C.; Cammi, R.; Ochterski, J. W.; Martin, R. L.; Morokuma, K.; Farkas, O.; Foresman, J. B.; Fox, D. J. Gaussian, Inc., Wallingford CT, 2016.

S6 Smith, S. G.; Goodman, J. M. J. Am. Chem. Soc. 2010, 132, 12946-12959. 
${ }^{1} \mathrm{H}$ NMR spectrum $\left(500 \mathrm{MHz}, \mathrm{CDCl}_{3}\right)$ of AKML A (1)

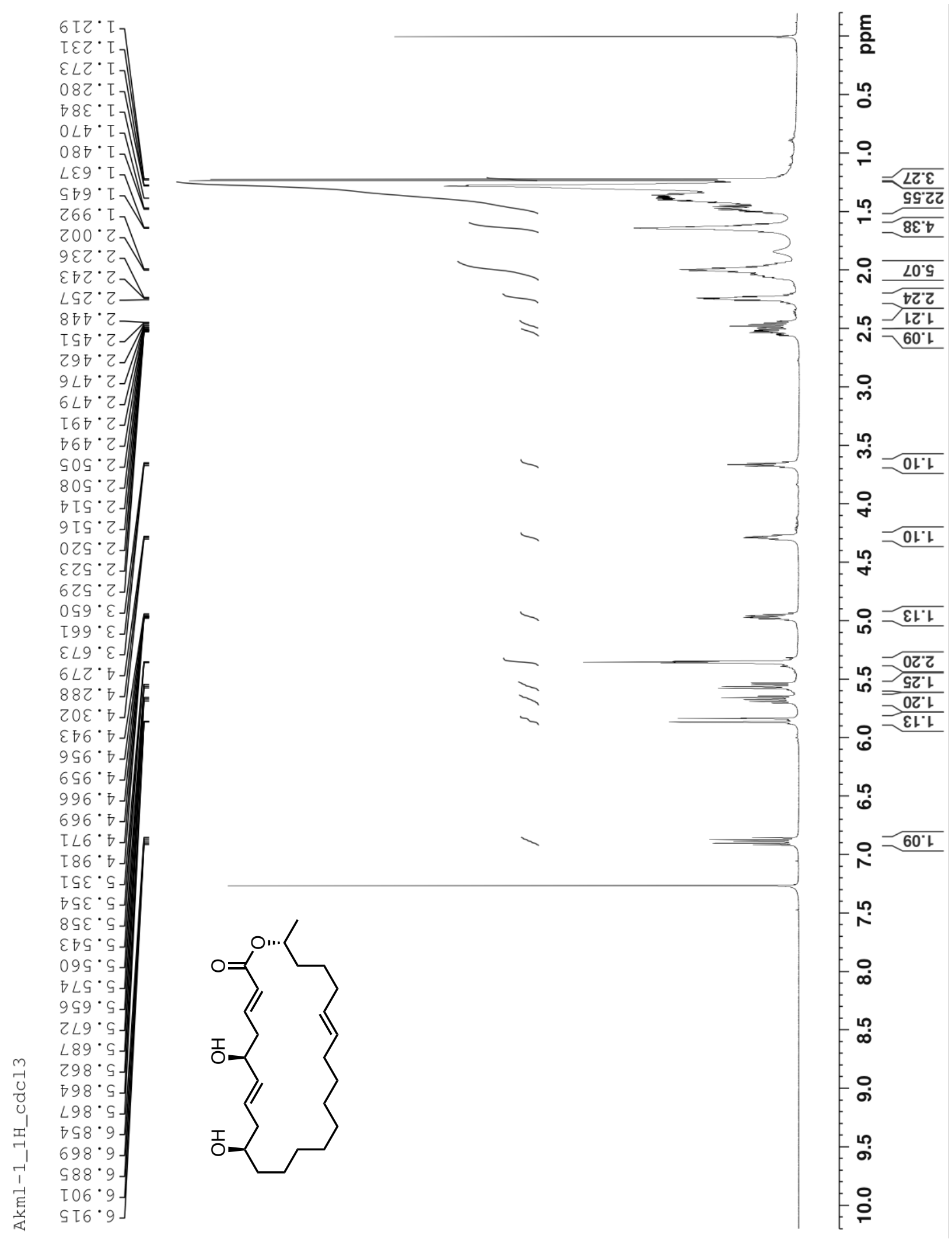


${ }^{13} \mathrm{C}$ NMR spectrum (125 MHz, $\left.\mathrm{CDCl}_{3}\right)$ of $\mathrm{AKML} \mathrm{A} \mathrm{(1)}$

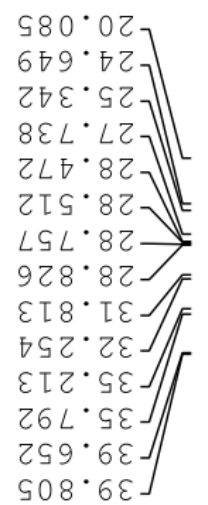

$\tau 26^{\circ} O L$
$\angle 90^{\circ} \mathrm{TL} \backslash$
$809^{\circ} \mathrm{TL}$

$0 \nabla S^{*} \nabla Z \tau$

IZL.8ZT

$\mathrm{ST \tau} \cdot 0 \varepsilon \mathrm{T}$

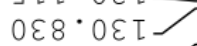

s $8 \nabla^{\circ} \nabla \varepsilon \tau$

$\tau 29 \cdot \varepsilon \nabla \tau$

$606^{\circ} 99 \tau$

$m$
$m$
0
0
0
0
0
0
-1
-1
-1
$\vec{E}$
$\vec{y}$
$\overrightarrow{4}$
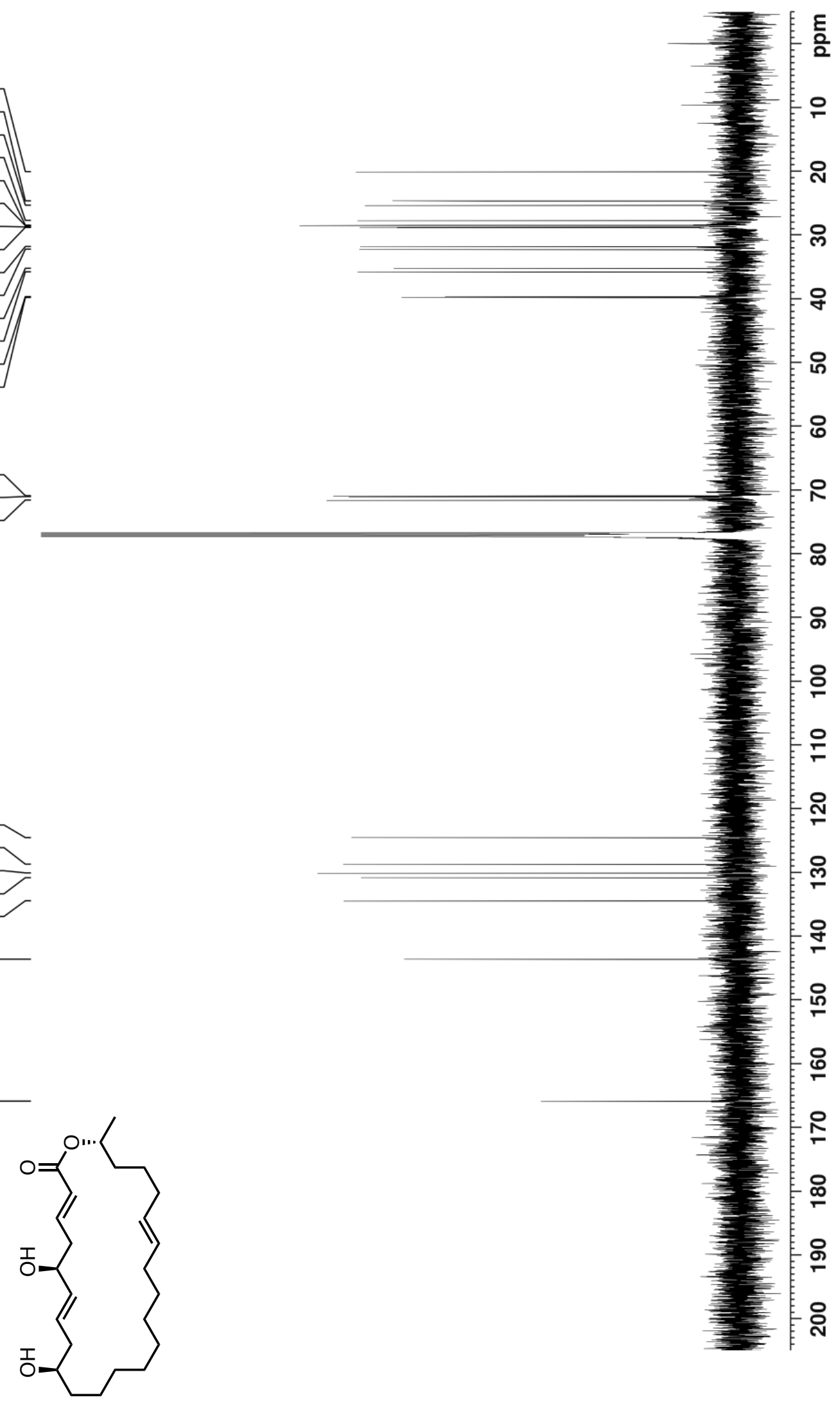
${ }^{1} \mathrm{H}-{ }^{1} \mathrm{H}$ COSY spectrum $\left(\mathrm{CDCl}_{3}\right)$ of AKML A (1)

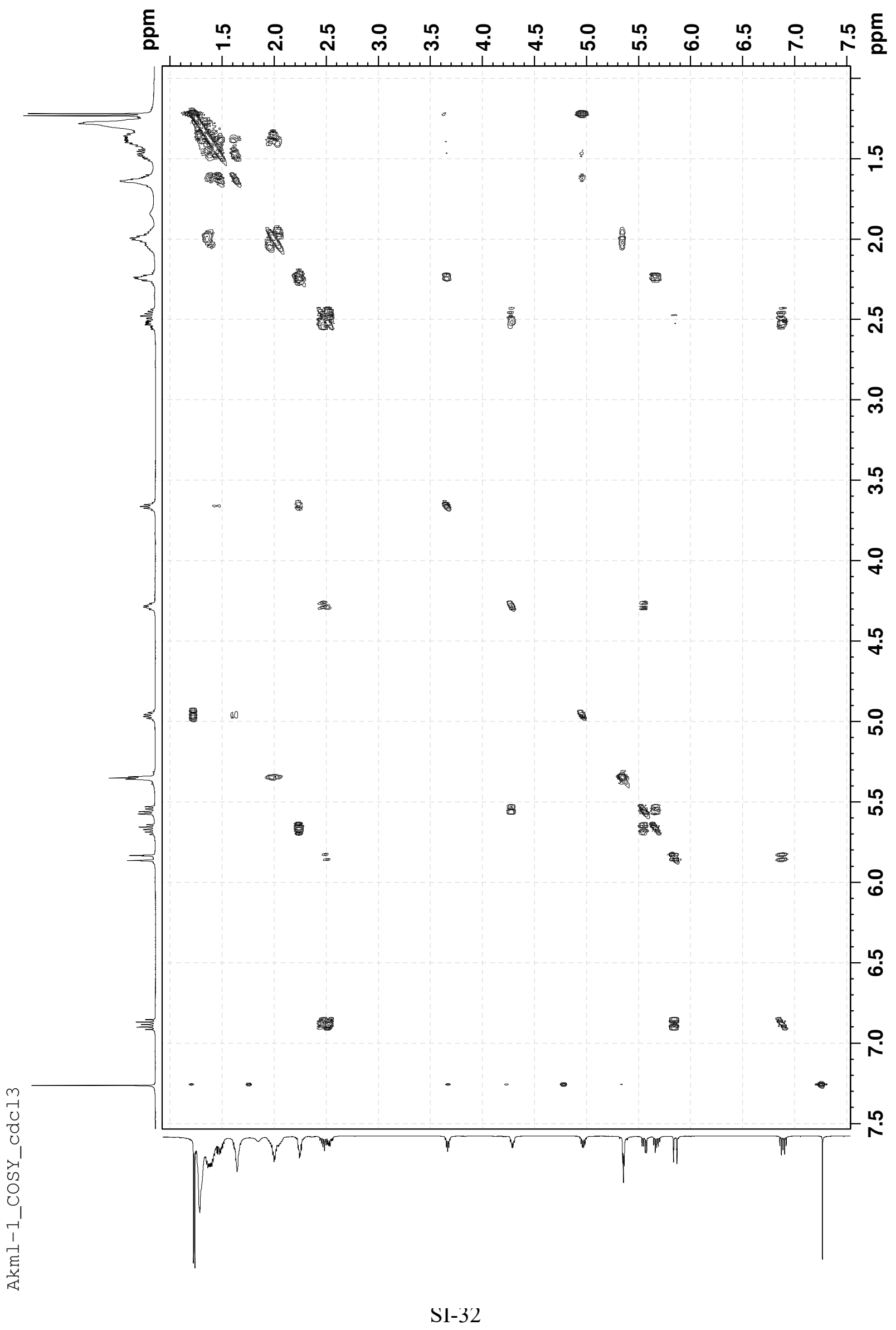


HMBC spectrum $\left(\mathrm{CDCl}_{3}\right)$ of AKML A (1)

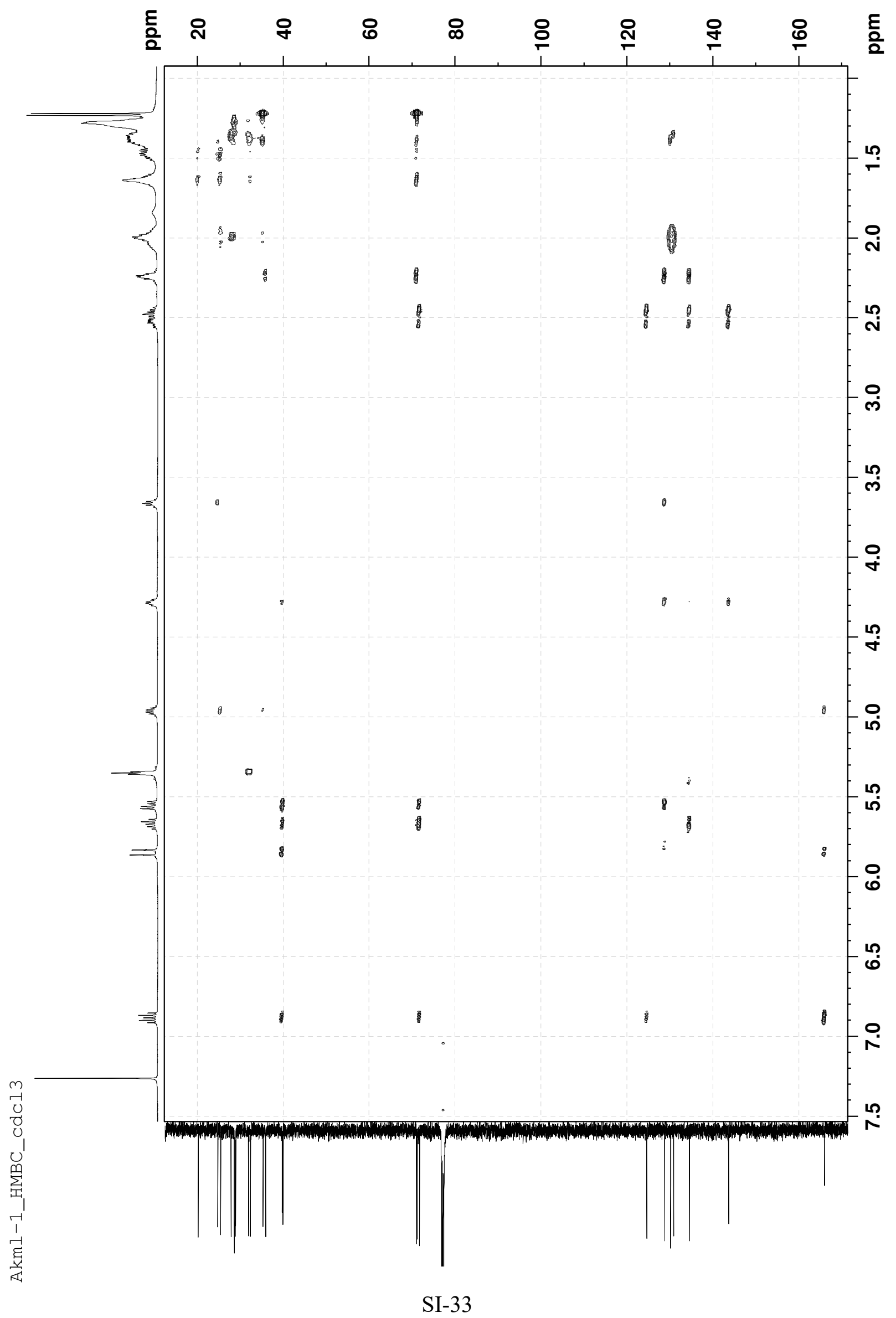


HSQC spectrum $\left(\mathrm{CDCl}_{3}\right)$ of AKML A (1)

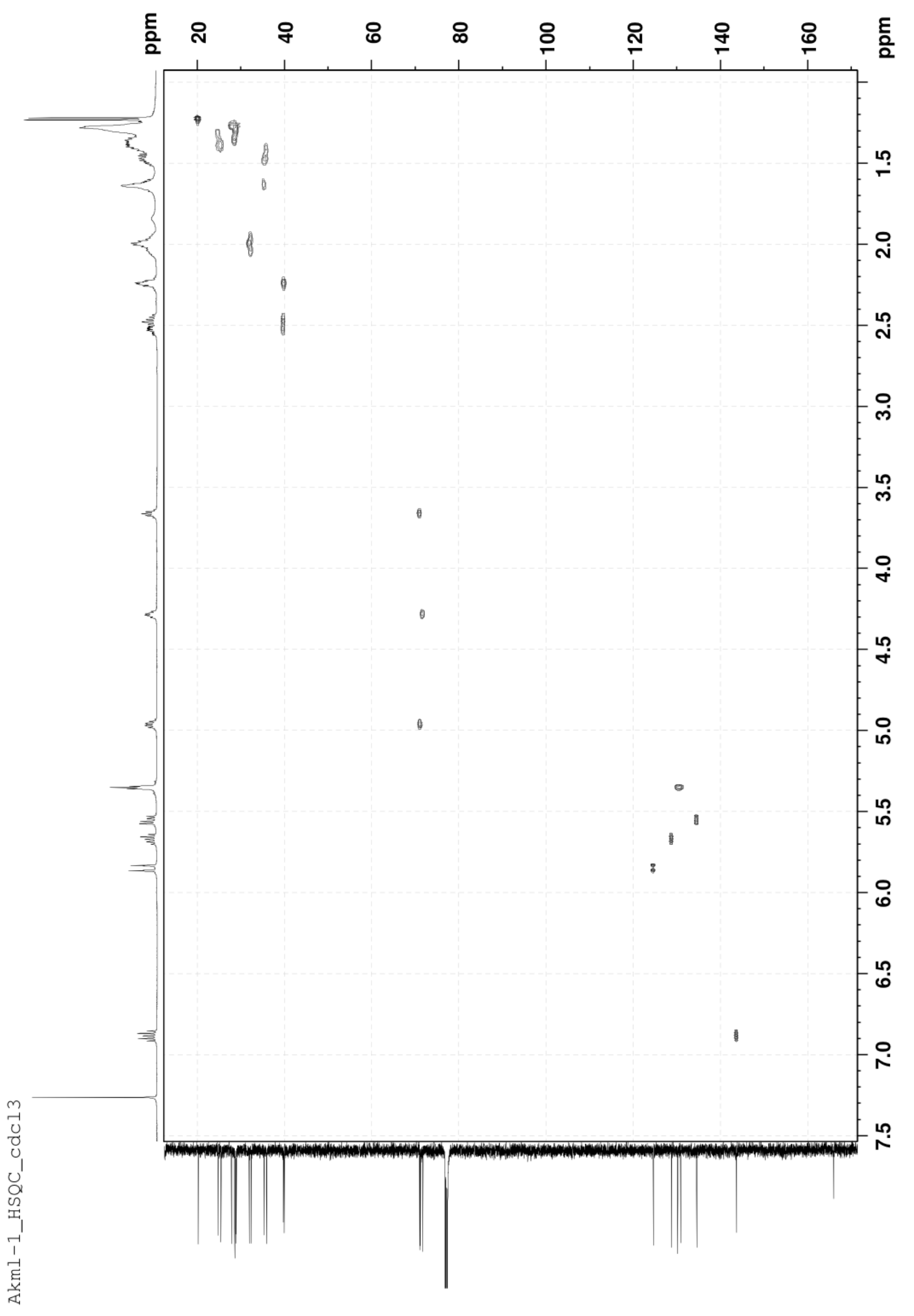


${ }^{1} \mathrm{H}$ NMR spectrum $\left(500 \mathrm{MHz}, \mathrm{CD}_{3} \mathrm{OD}\right)$ of AKML B (2)

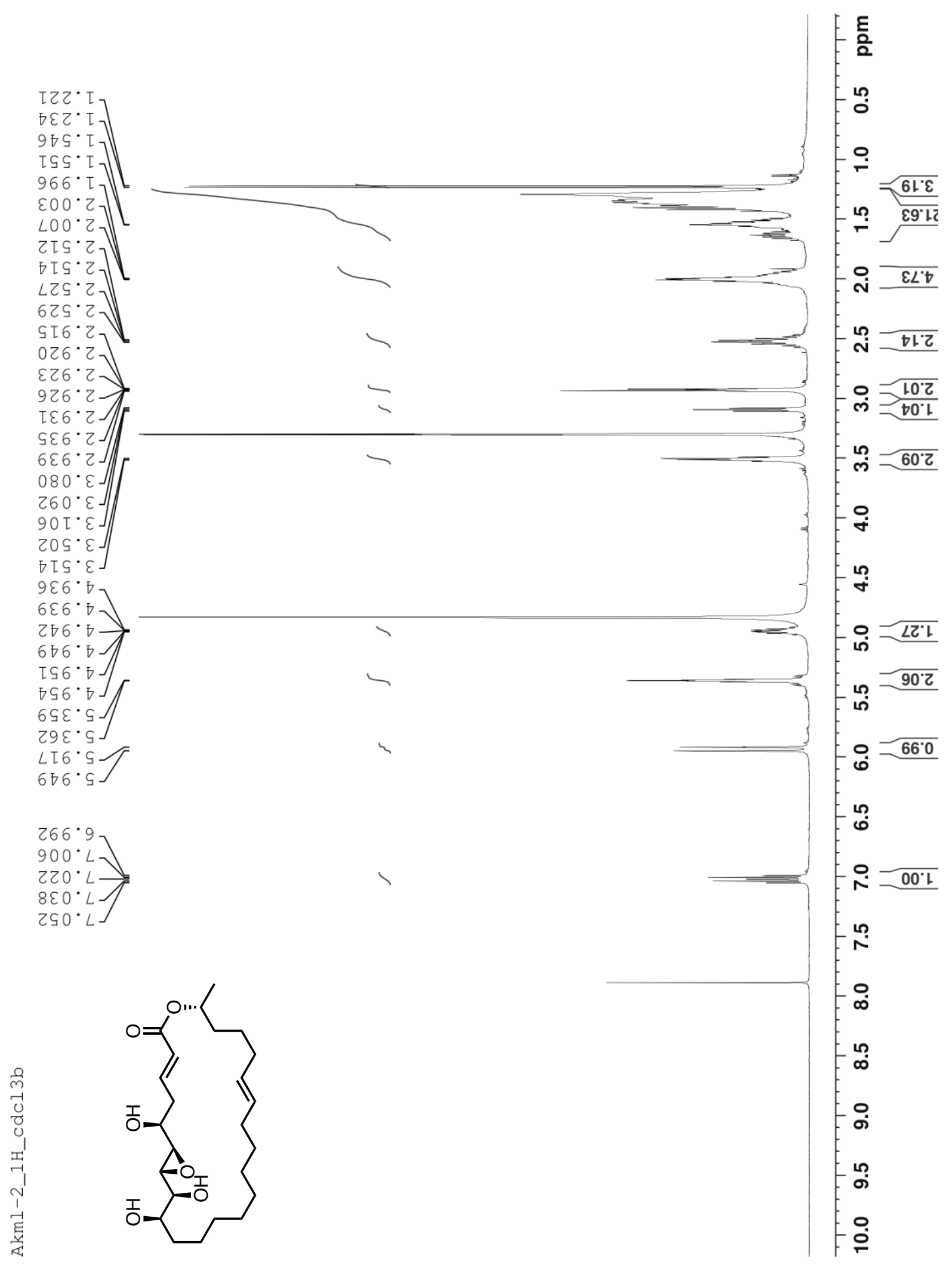


${ }^{13} \mathrm{C}$ NMR spectrum (150 MHz, $\left.\mathrm{CD}_{3} \mathrm{OD}\right)$ of AKML B (2)

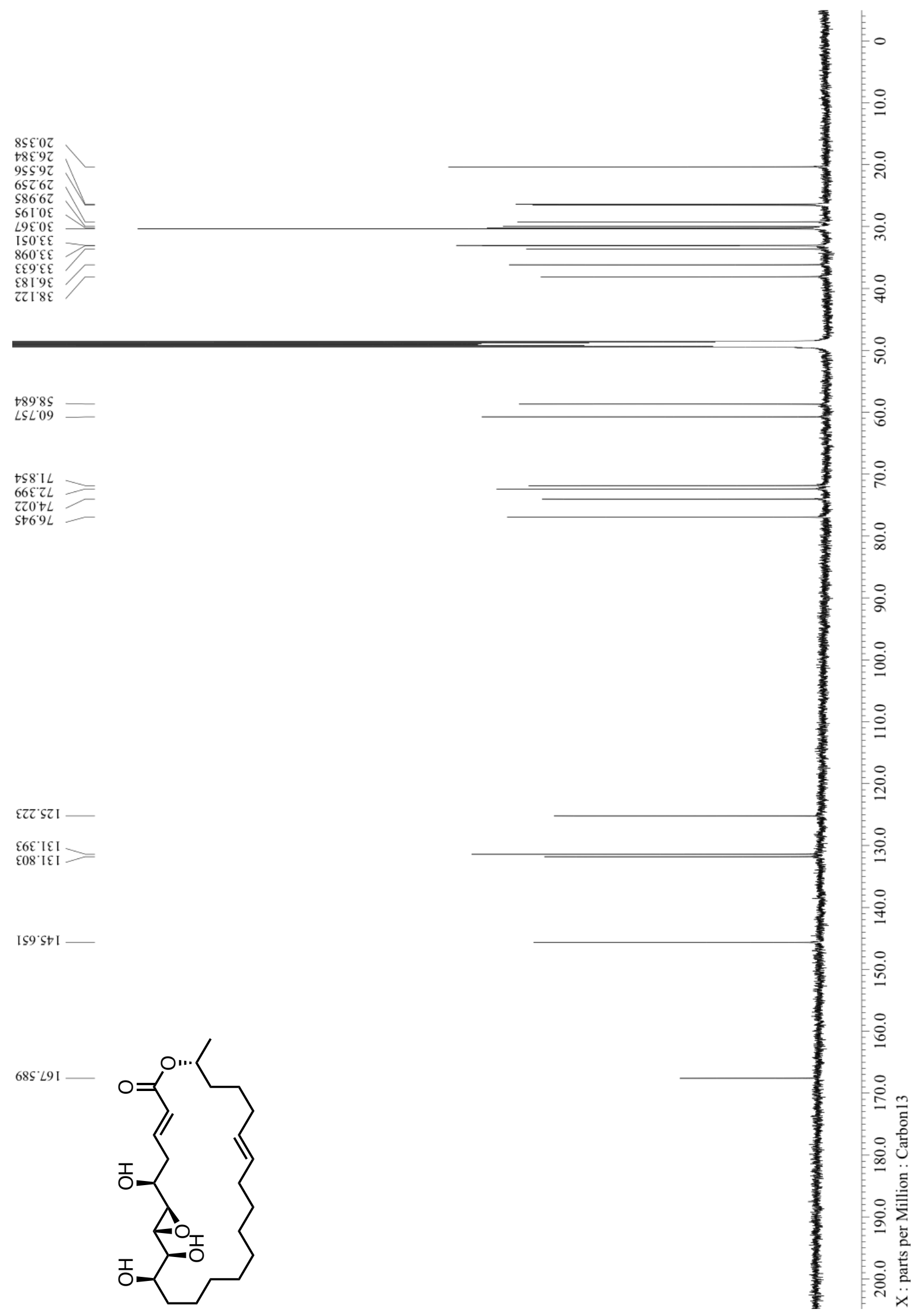


${ }^{1} \mathrm{H}-{ }^{1} \mathrm{H}$ COSY spectrum $\left(\mathrm{CD}_{3} \mathrm{OD}\right)$ of AKML B (2)

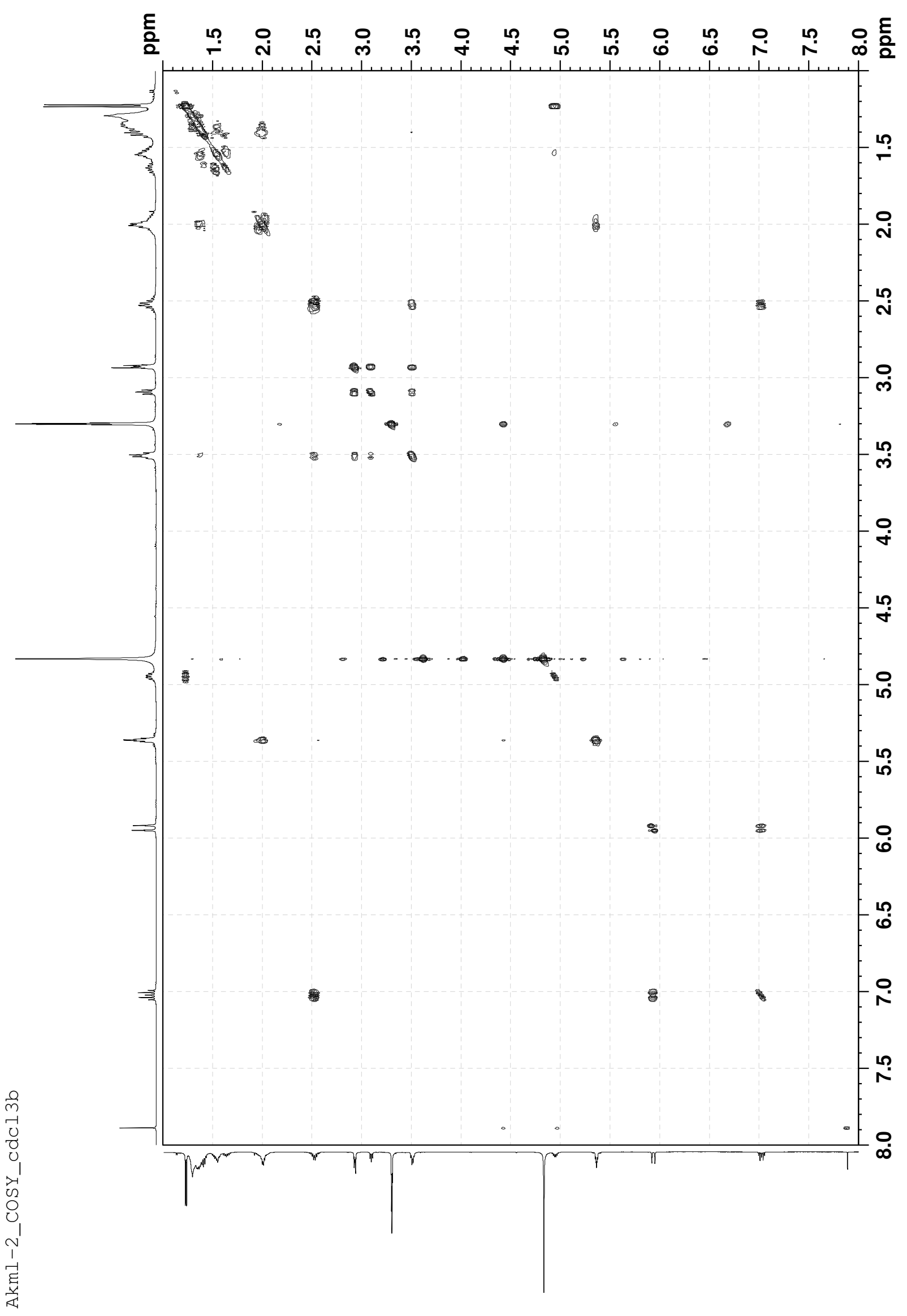


HMBC spectrum $\left(\mathrm{CD}_{3} \mathrm{OD}\right)$ of AKML B (2)

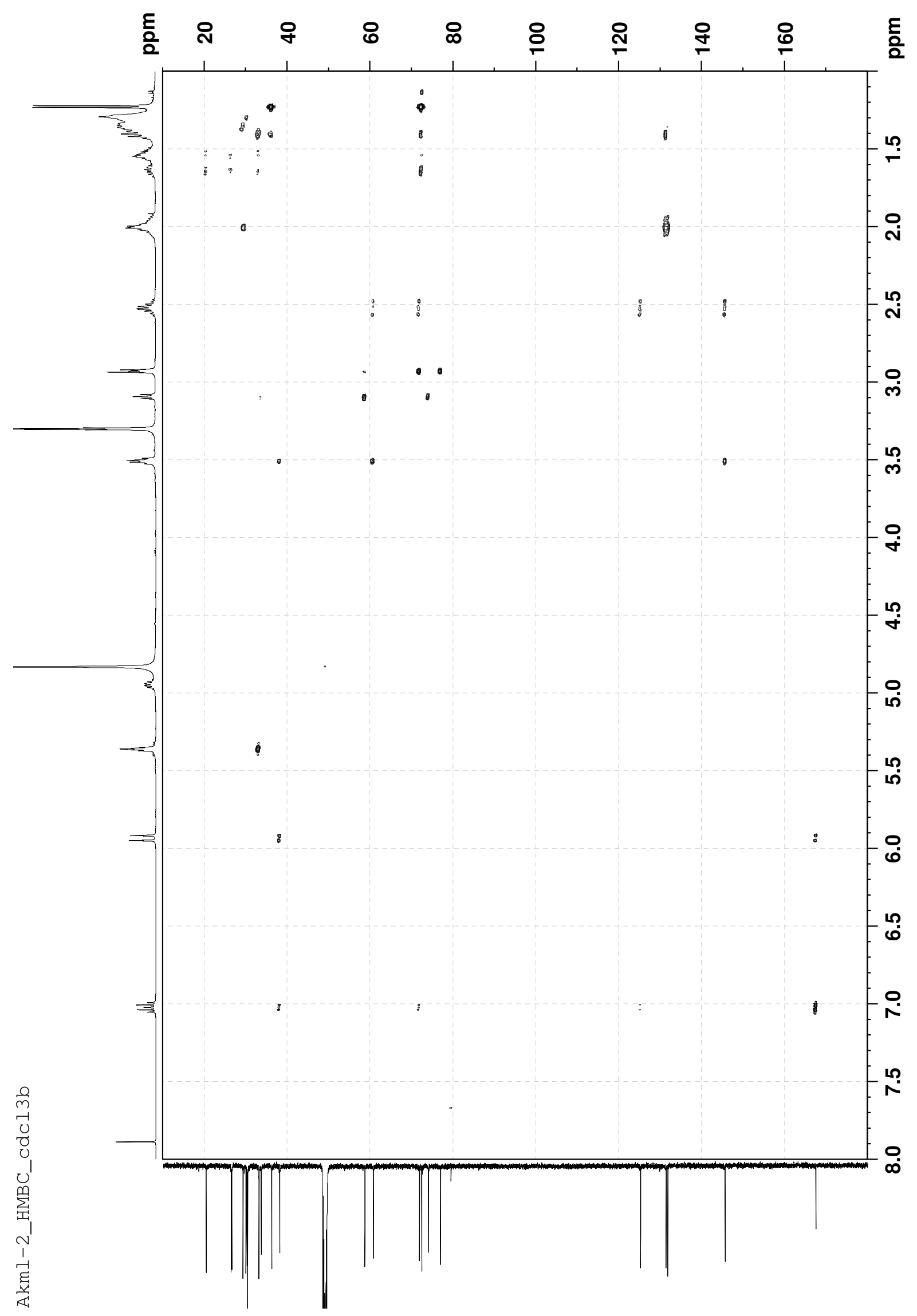


HSQC spectrum $\left(\mathrm{CD}_{3} \mathrm{OD}\right)$ of AKML B (2)

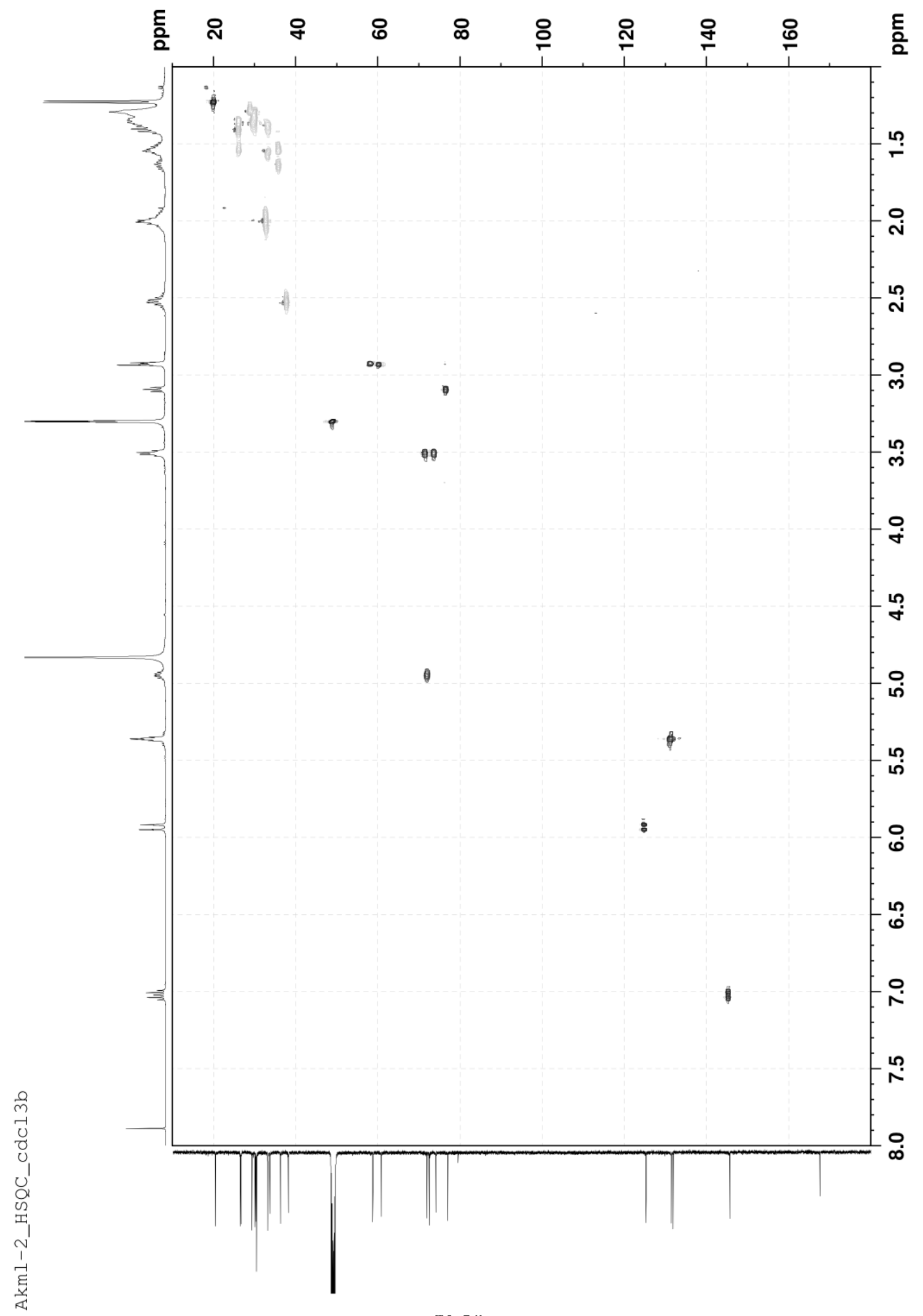


HSQC-TOCSY spectrum $\left(\mathrm{CD}_{3} \mathrm{OD}\right)$ of AKML B (2)

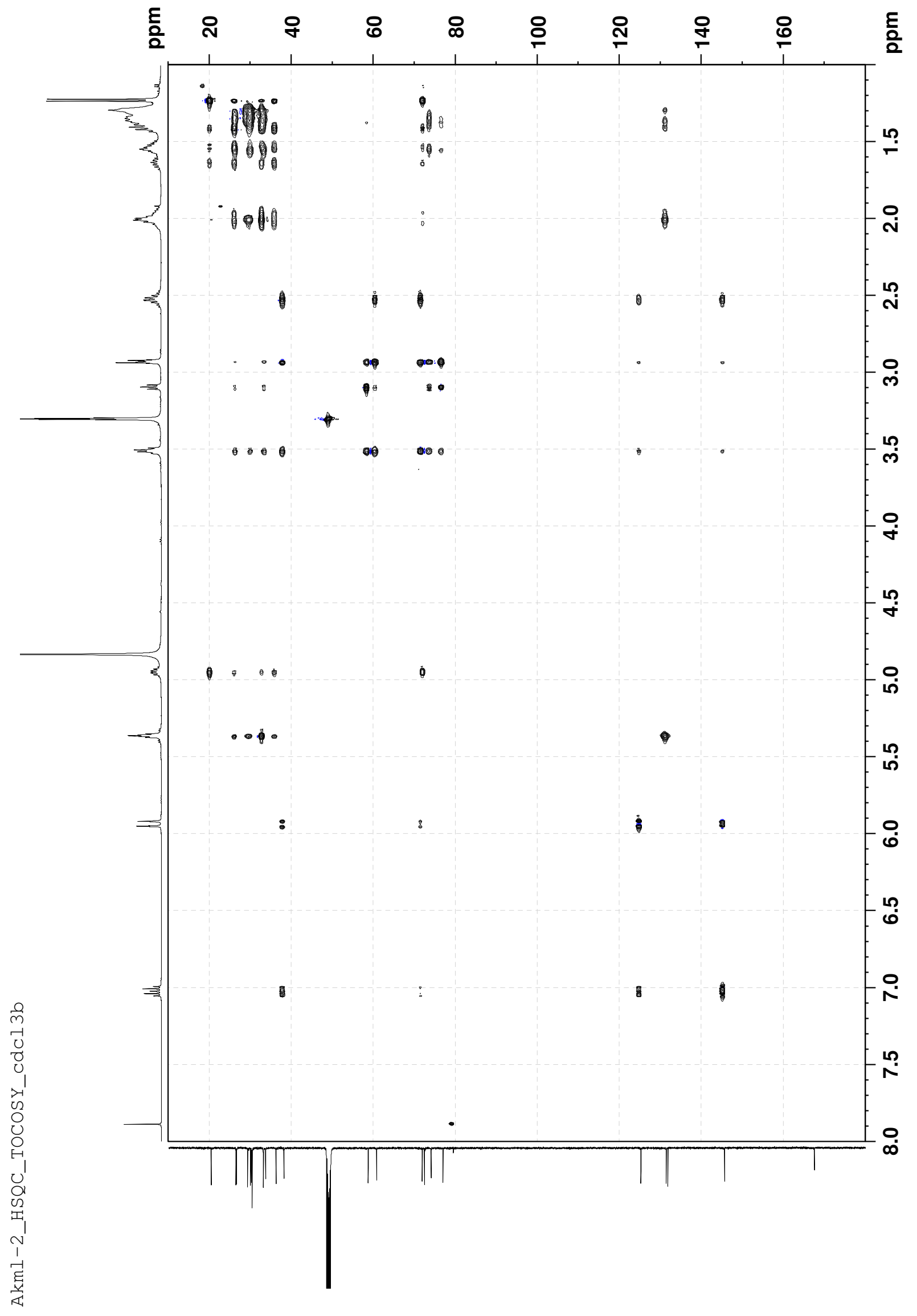


${ }^{1} \mathrm{H}$ NMR spectrum $\left(500 \mathrm{MHz}, \mathrm{CD}_{3} \mathrm{OD}\right)$ of AKML C (3)

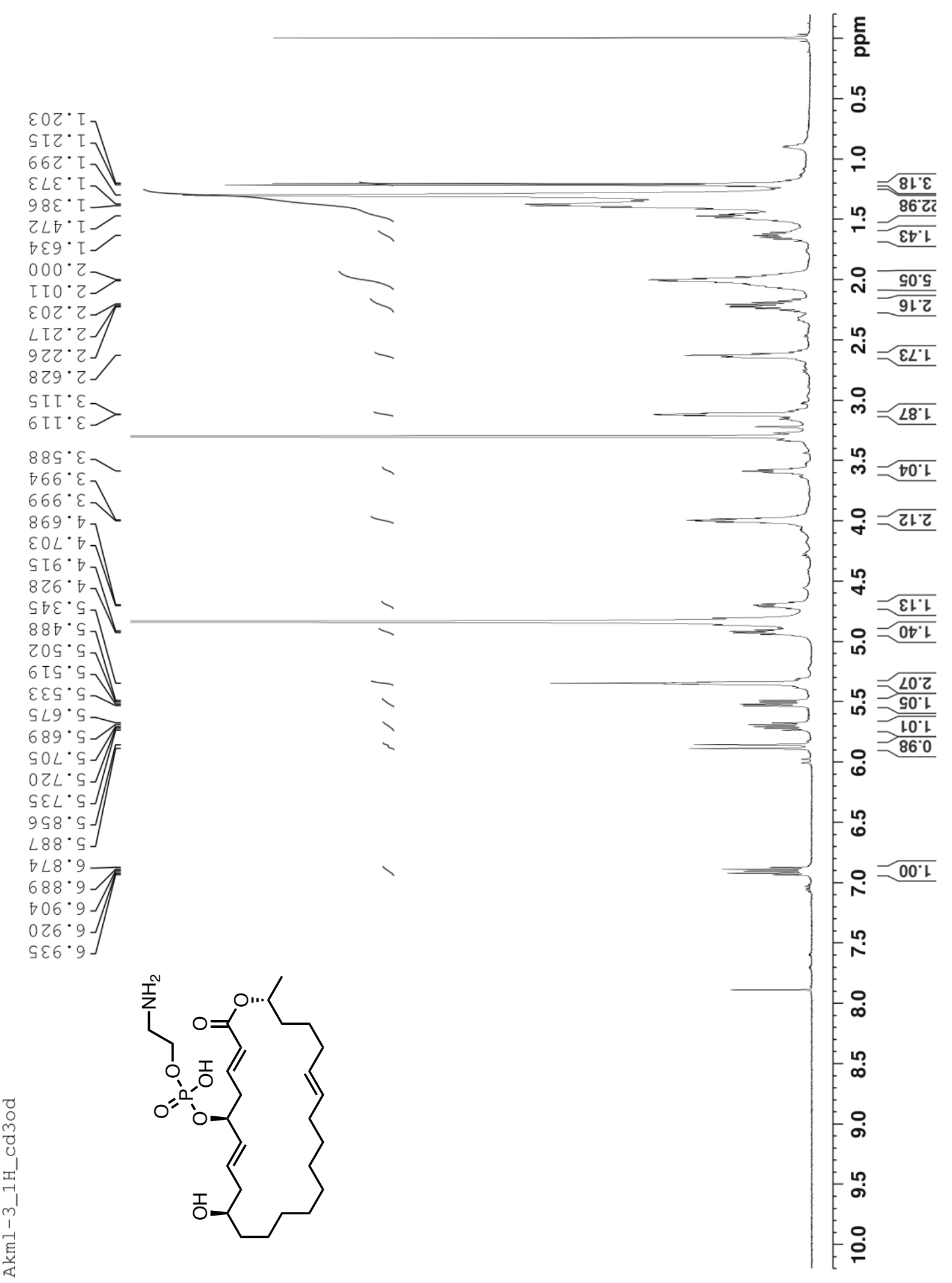


${ }^{13} \mathrm{C}$ NMR spectrum $\left(150 \mathrm{MHz}, \mathrm{CD}_{3} \mathrm{OD}\right)$ of AKML C (3)

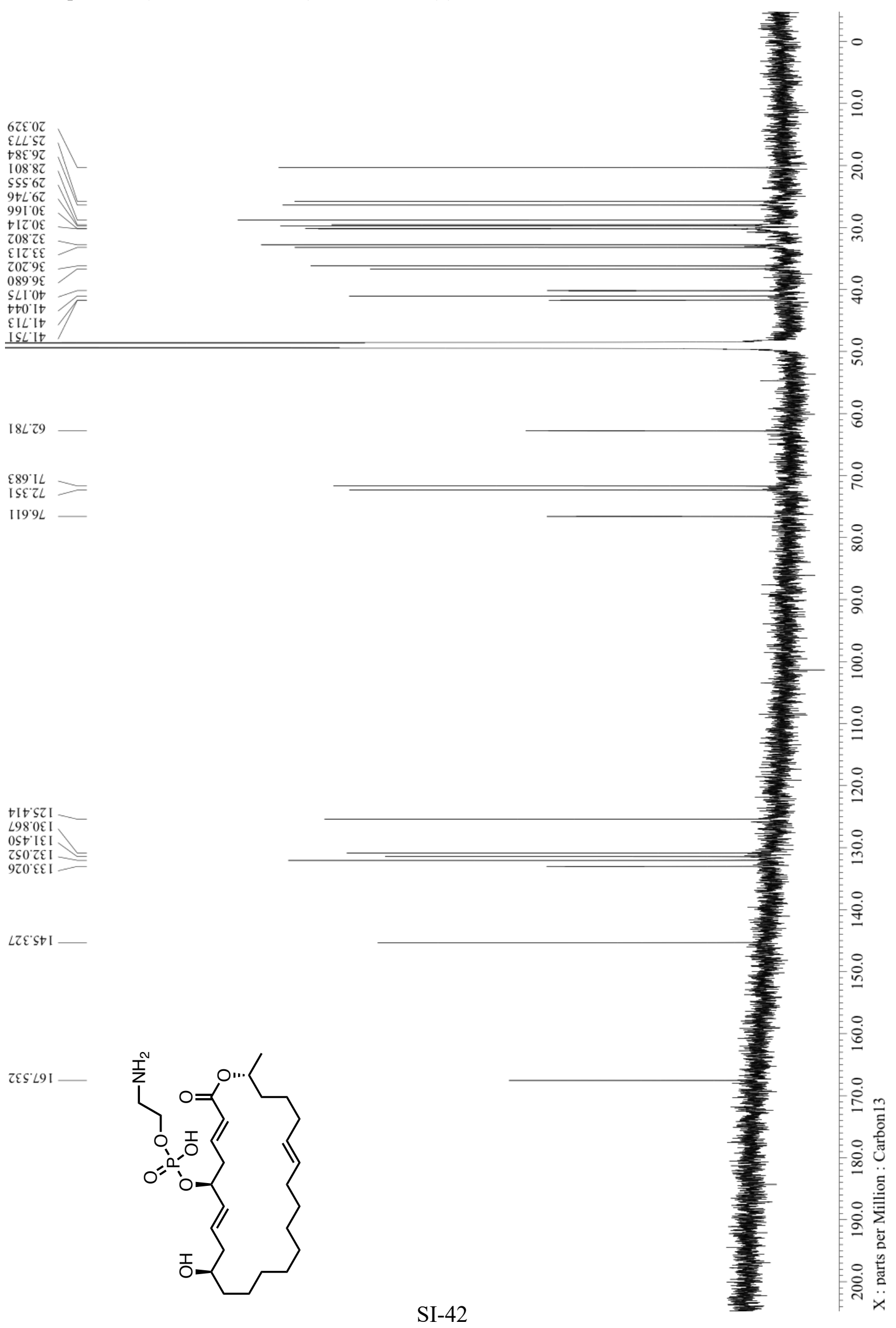

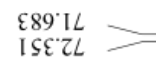

II $9^{\circ} 9 \mathrm{~L}$

$t I T^{\circ} S Z I$
L98 I

0St IE I

Zऽ० ZE I

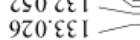

$L z \varepsilon \cdot s t \mathrm{I}$ 
${ }^{1} \mathrm{H}-{ }^{1} \mathrm{H}$ COSY spectrum $\left(\mathrm{CD}_{3} \mathrm{OD}\right)$ of AKML C (3)

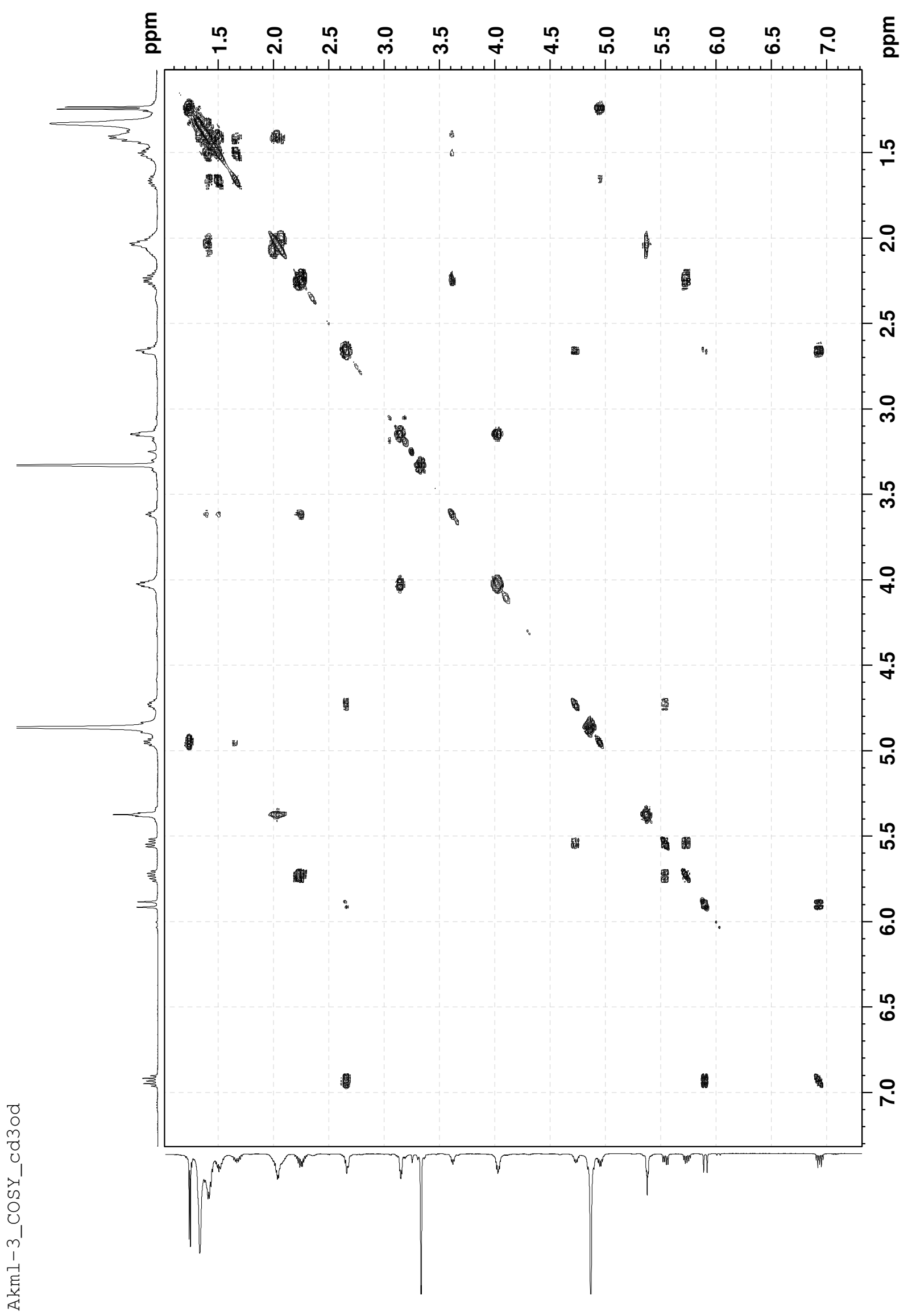


HMBC spectrum $\left(\mathrm{CD}_{3} \mathrm{OD}\right)$ of AKML C (3)

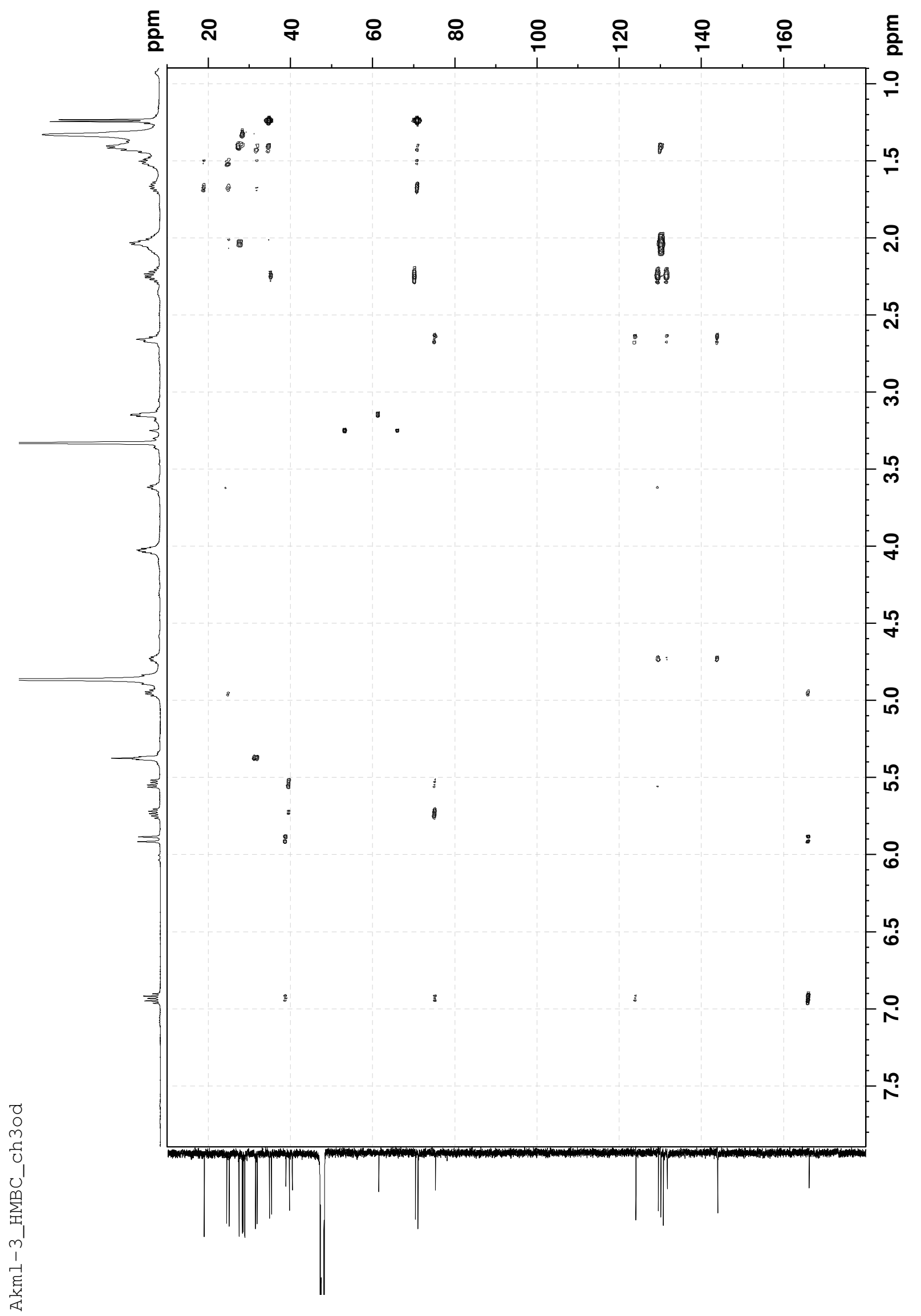


HSQC spectrum $\left(\mathrm{CD}_{3} \mathrm{OD}\right)$ of AKML C (3)

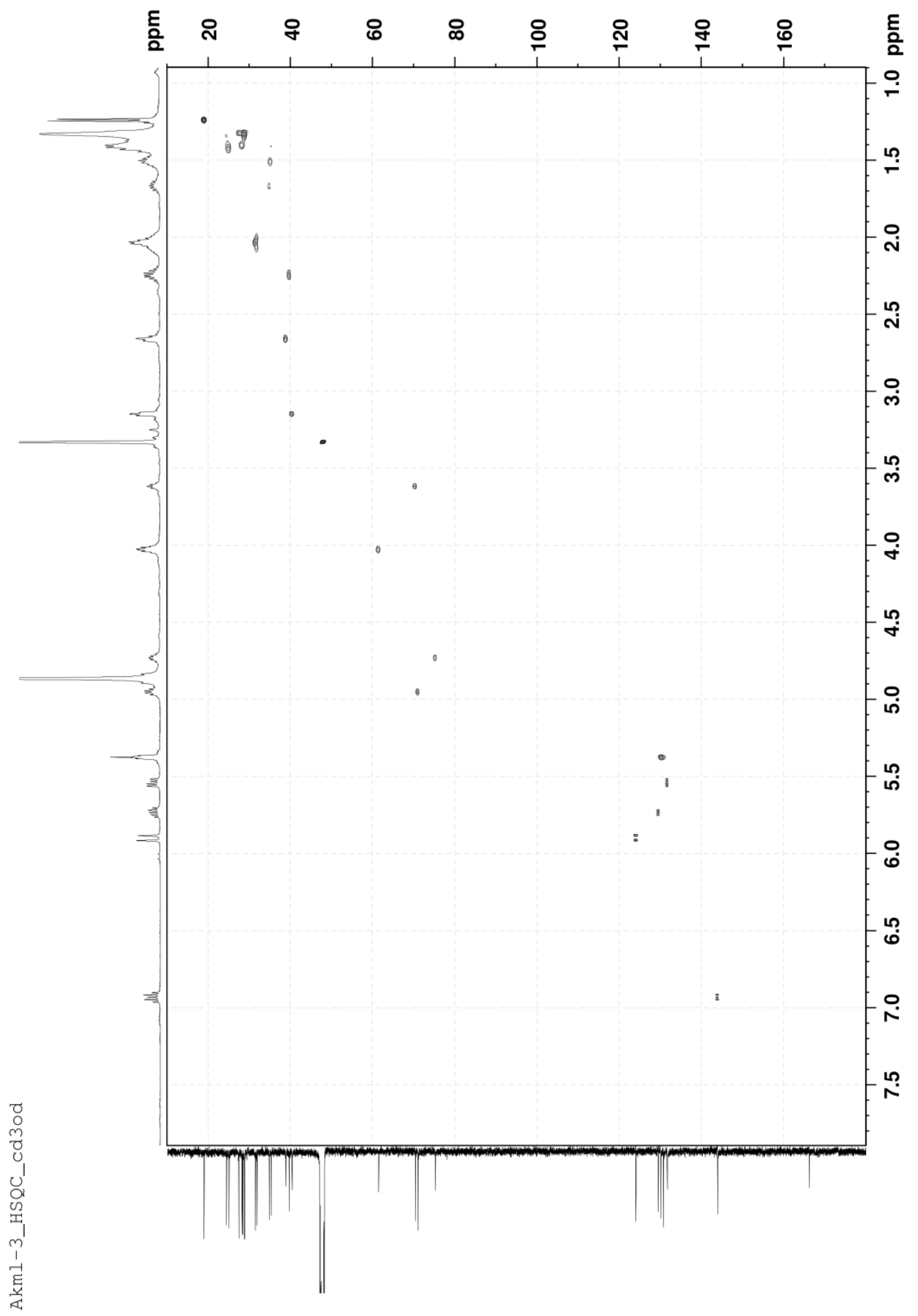


${ }^{1} \mathrm{H}$ NMR spectrum $\left(500 \mathrm{MHz}, \mathrm{CD}_{3} \mathrm{OD}\right)$ of AKML D (4)

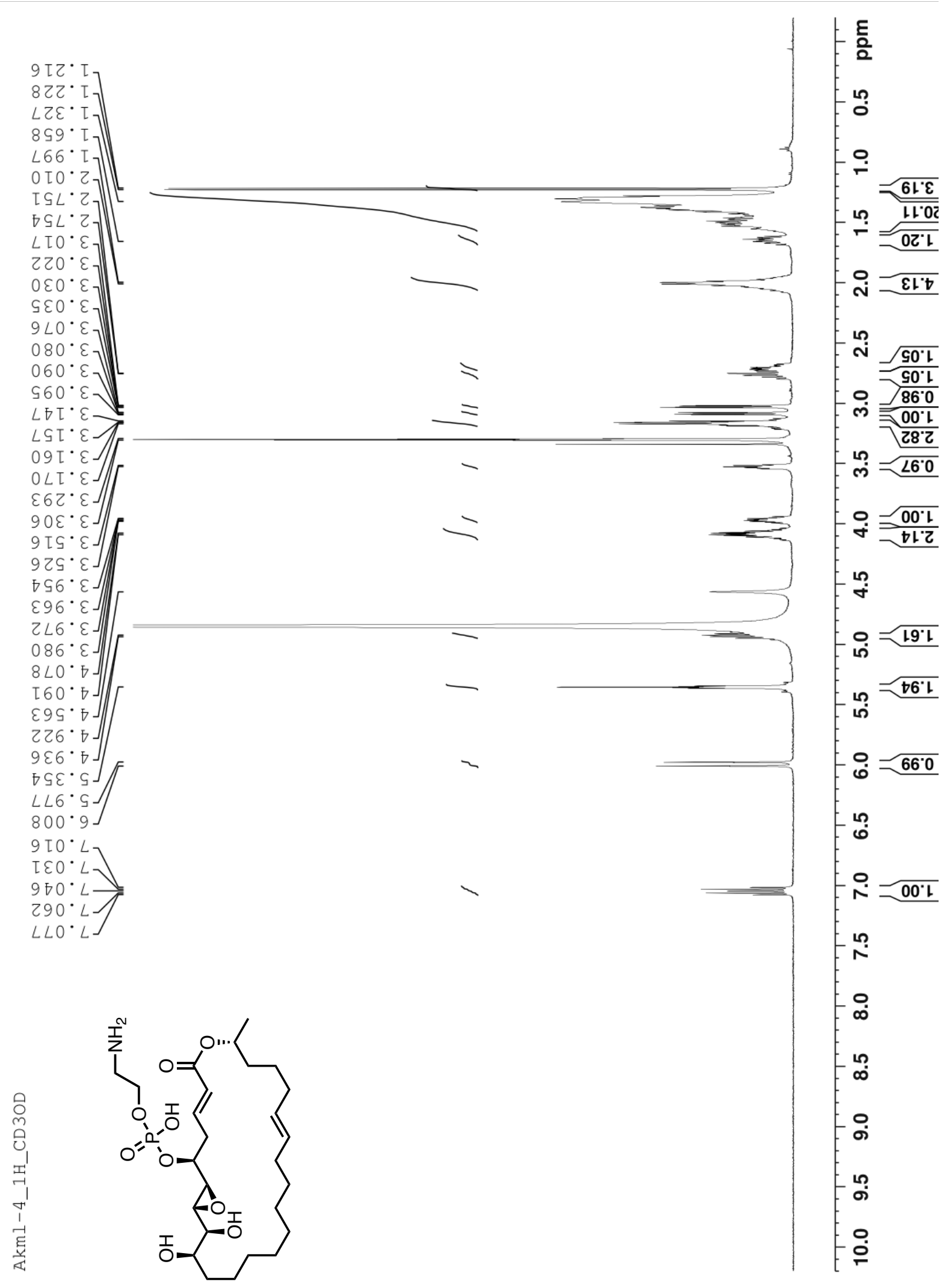


${ }^{13} \mathrm{C}$ NMR spectrum (125 MHz, $\left.\mathrm{CD}_{3} \mathrm{OD}\right)$ of AKML D (4)
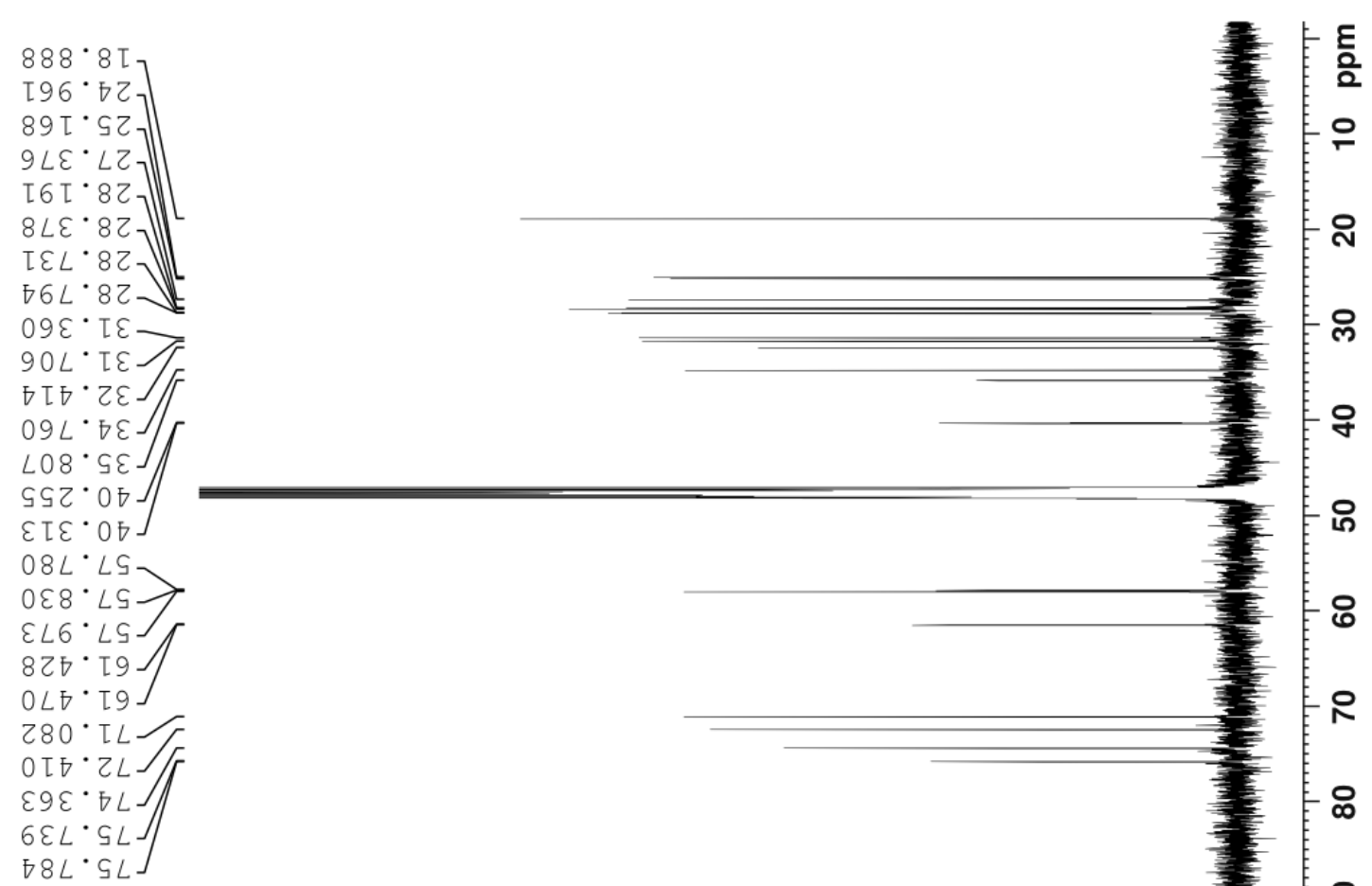

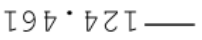

$090^{\circ} 0 \varepsilon \tau>$

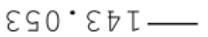

I60.99I -
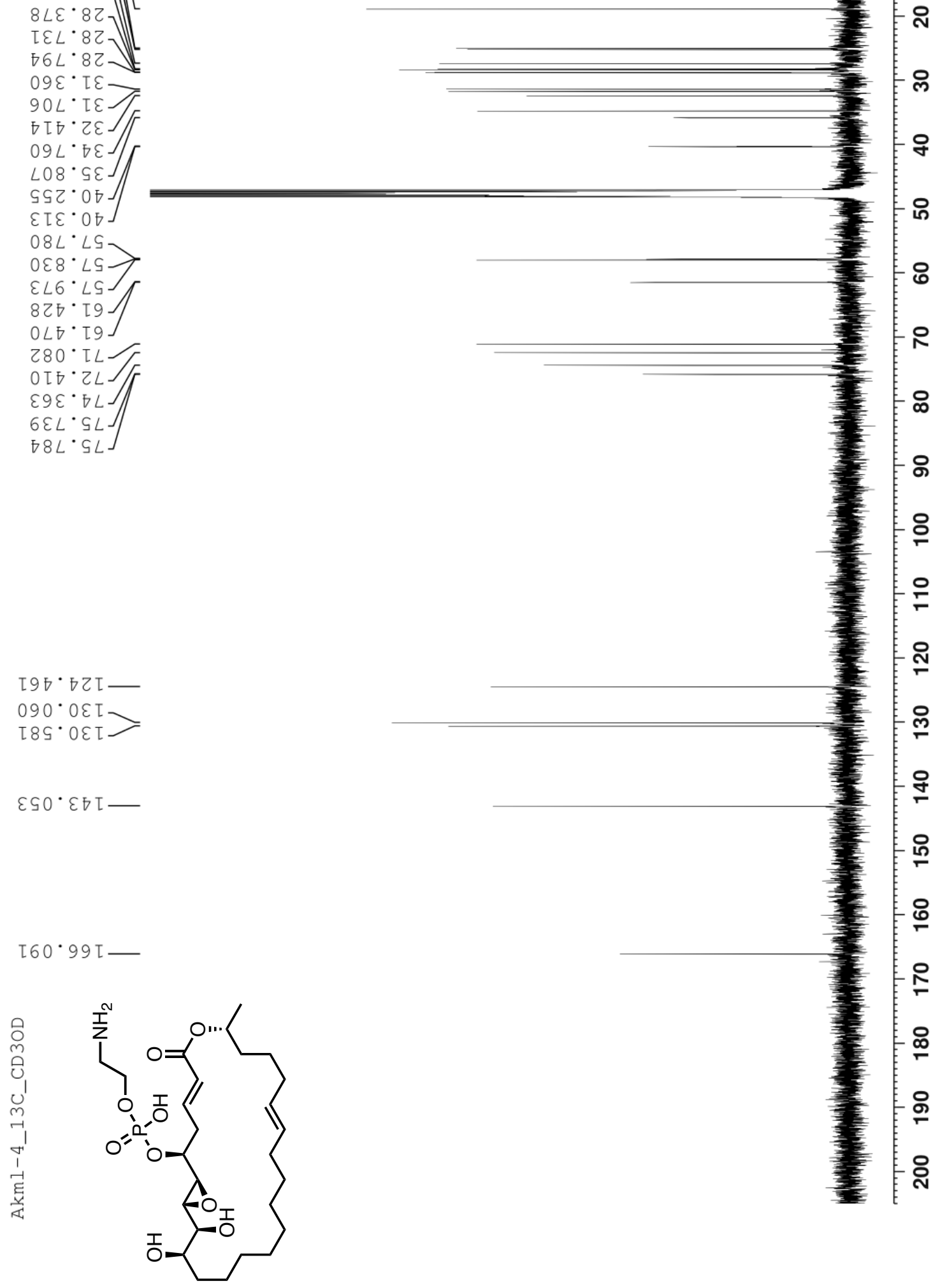

8

옹

○

8

음

음

오

으

운

유

$\stackrel{\circ}{\circ}$

$\stackrel{2}{\stackrel{2}{2}}$

$\stackrel{\infty}{\square}$

옴

ํํ 
${ }^{1} \mathrm{H}-{ }^{1} \mathrm{H}$ COSY spectrum $\left(\mathrm{CD}_{3} \mathrm{OD}\right)$ of AKML D (4)

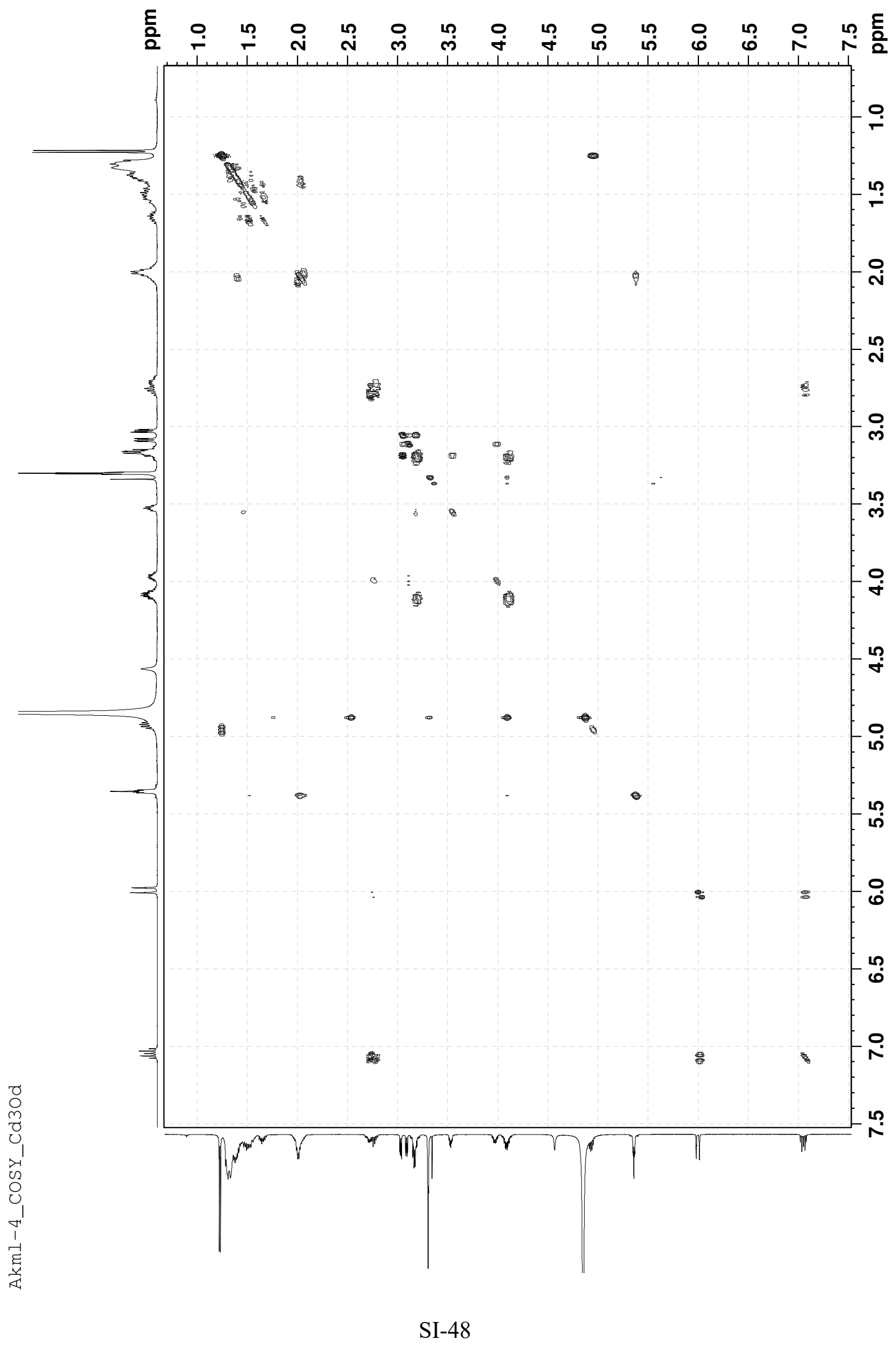


HMBC spectrum $\left(\mathrm{CD}_{3} \mathrm{OD}\right)$ of AKML D (4)

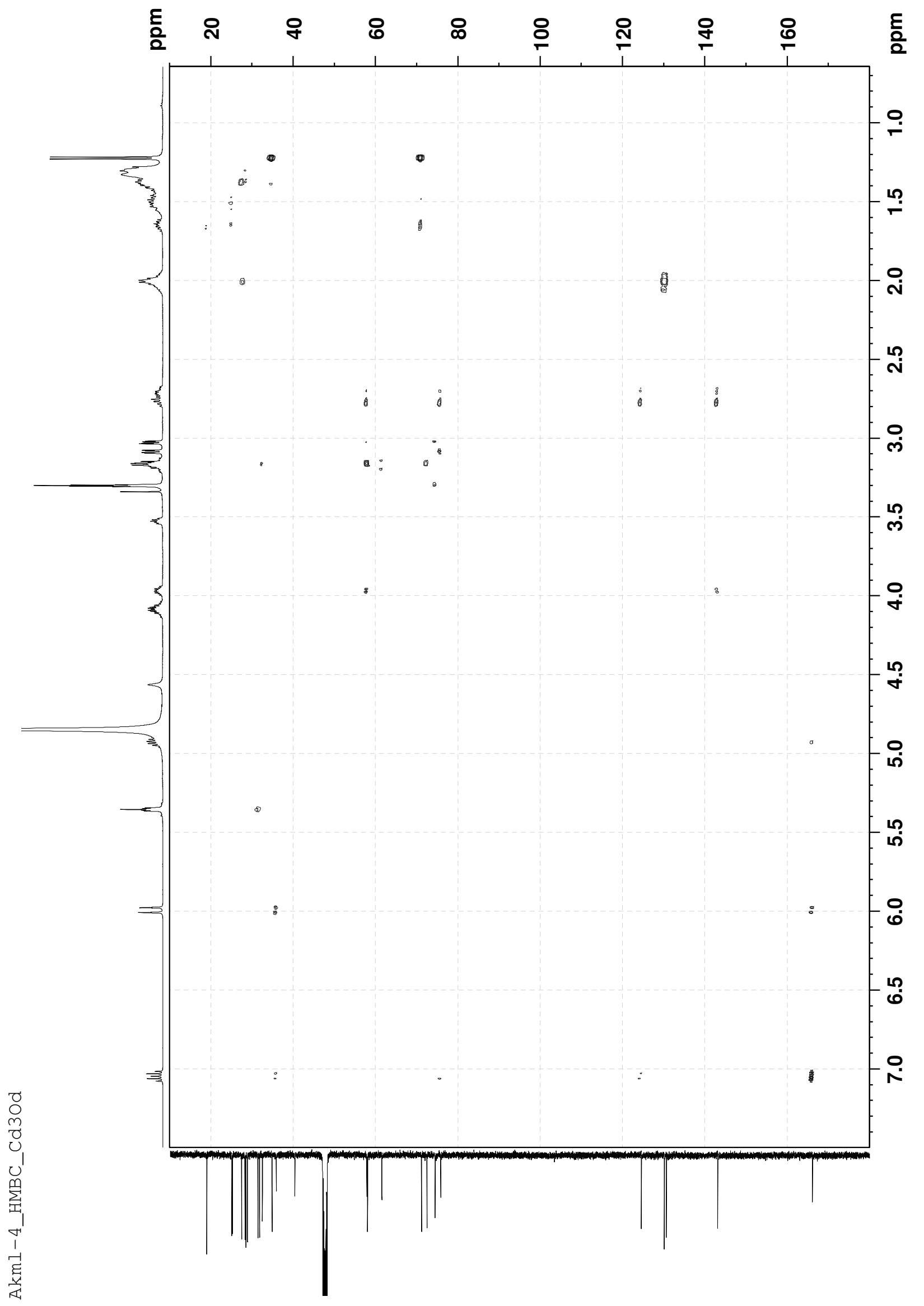


HSQC spectrum $\left(\mathrm{CD}_{3} \mathrm{OD}\right)$ of AKML D (4)

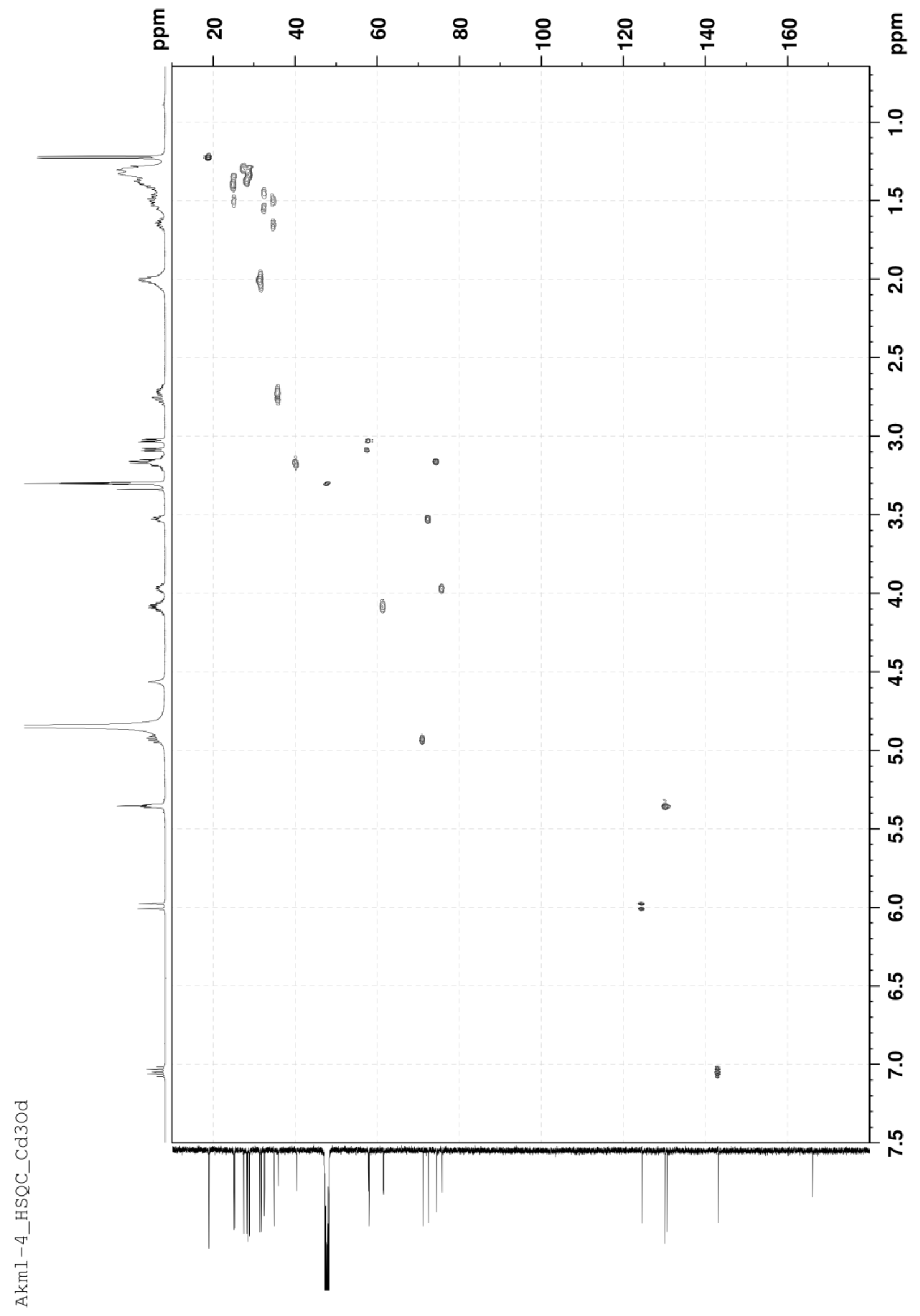


HSQC-TOCSY spectrum $\left(\mathrm{CD}_{3} \mathrm{OD}\right)$ of AKML D (4)

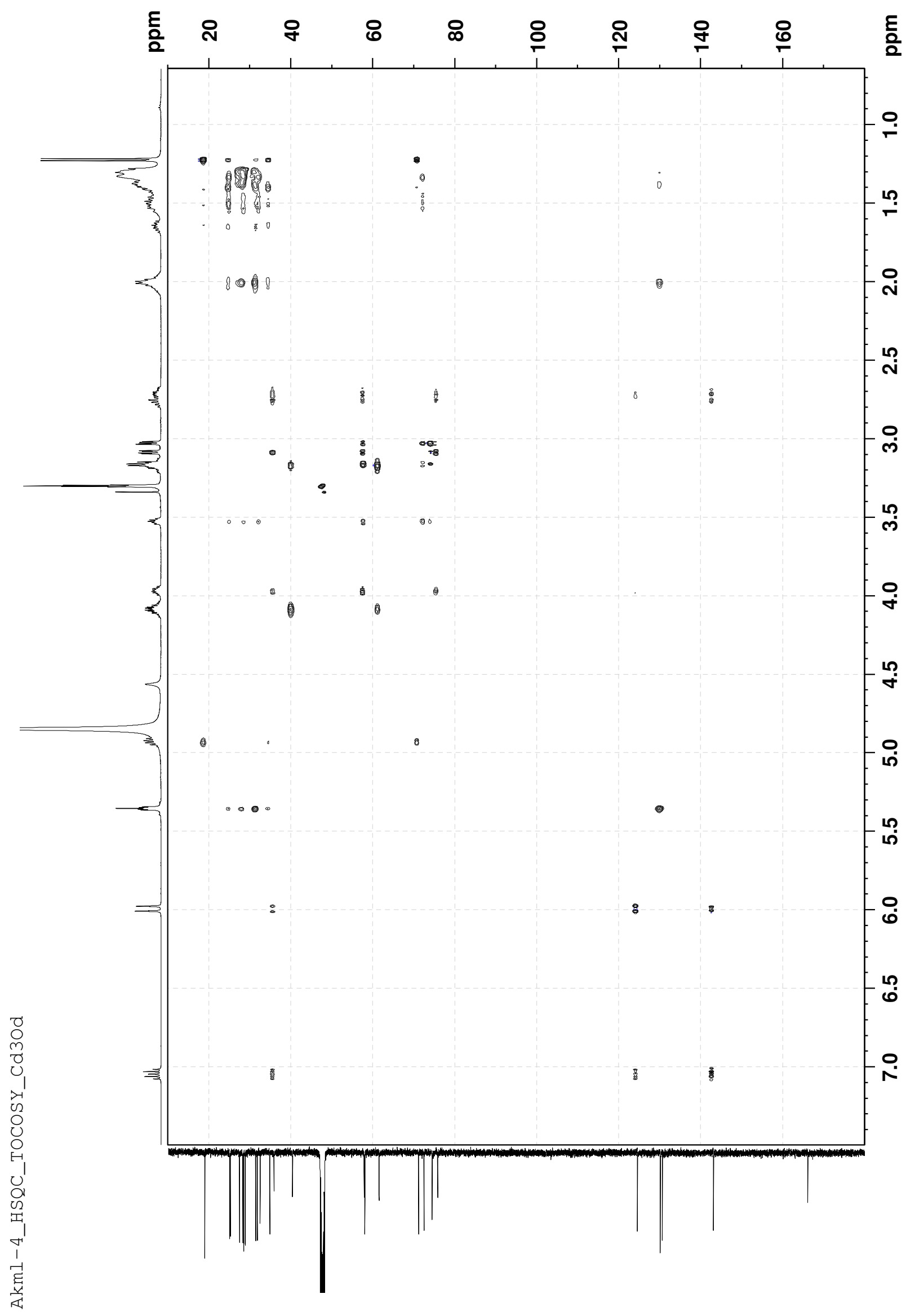


${ }^{1} \mathrm{H}$ NMR spectrum (500 MHz, $\mathrm{CDCl}_{3}$ ) of CIML A (5)

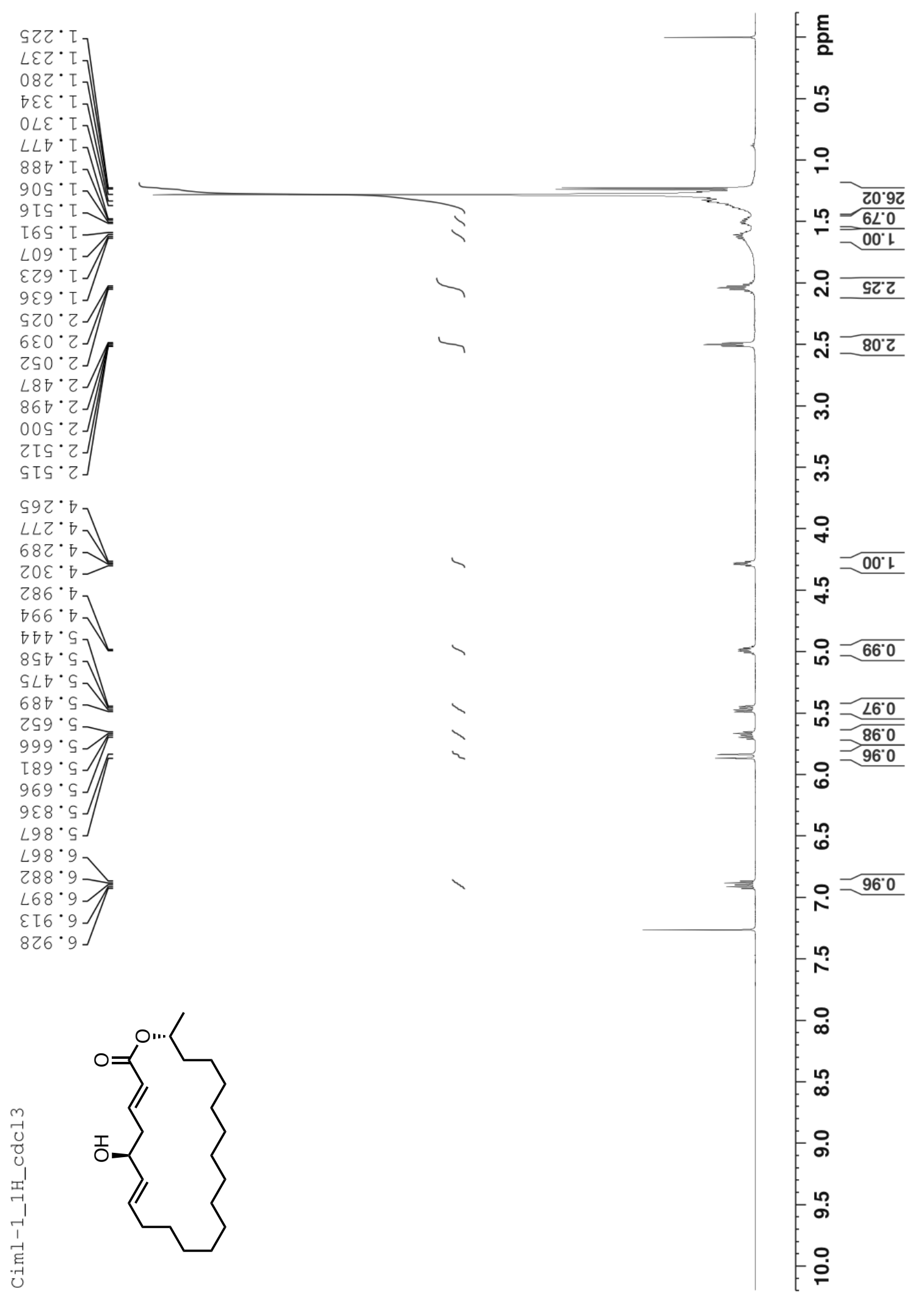


${ }^{13} \mathrm{C}$ NMR spectrum (125 MHz, $\left.\mathrm{CDCl}_{3}\right)$ of CIML A (5)

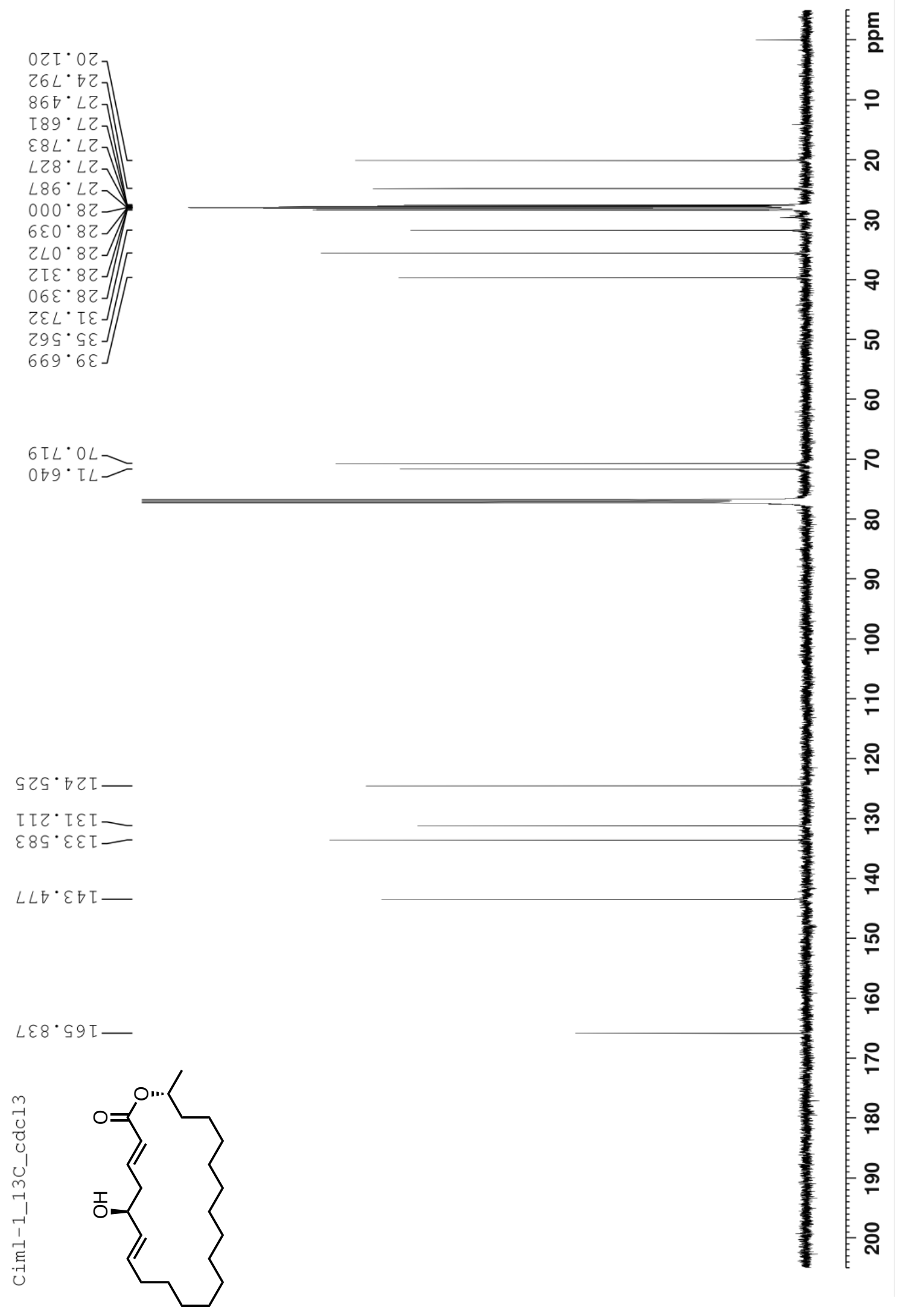


${ }^{1} \mathrm{H}-{ }^{1} \mathrm{H}$ COSY spectrum $\left(\mathrm{CDCl}_{3}\right)$ of CIML A (5)

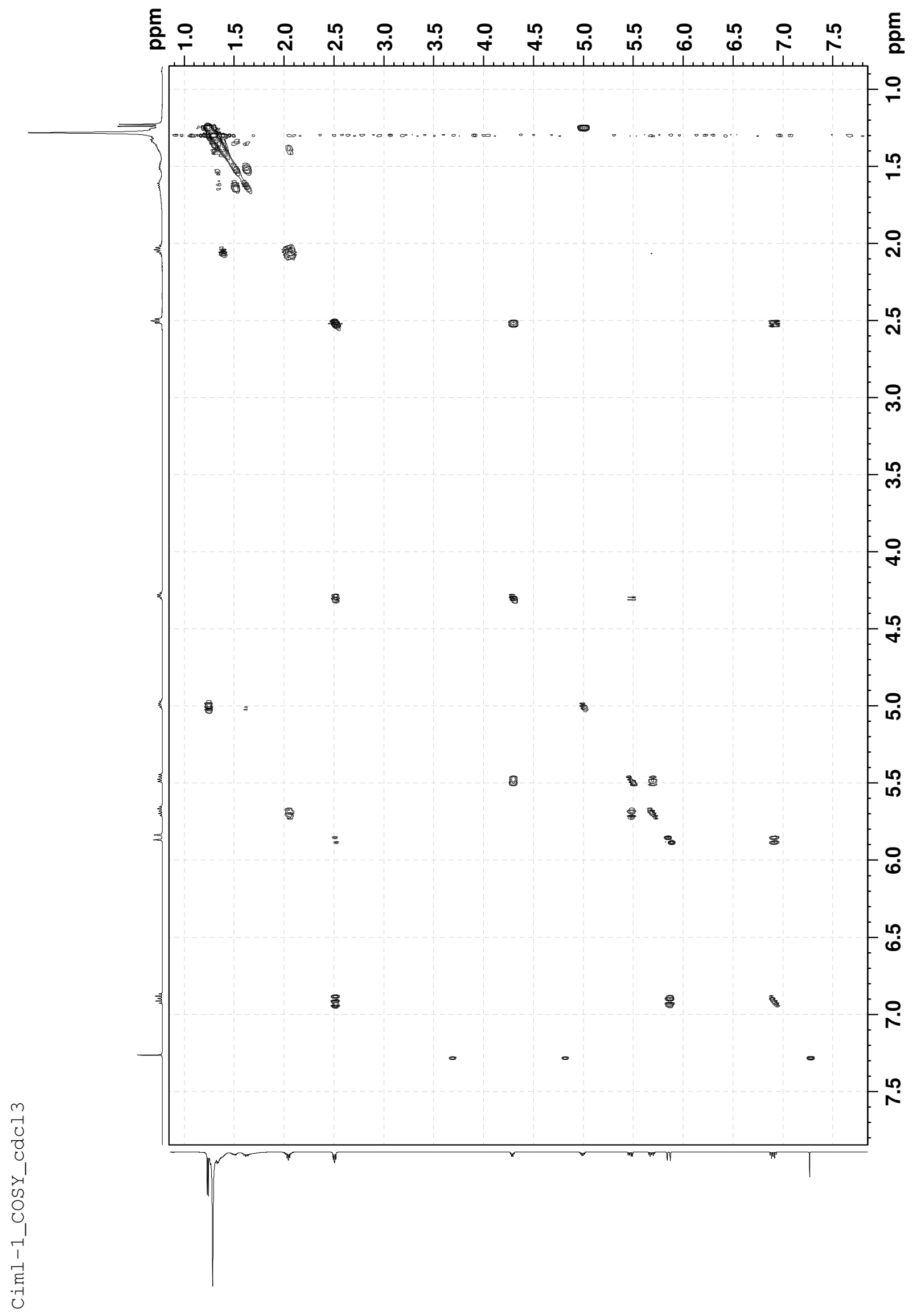


HMBC spectrum $\left(\mathrm{CDCl}_{3}\right)$ of CIML A (5)

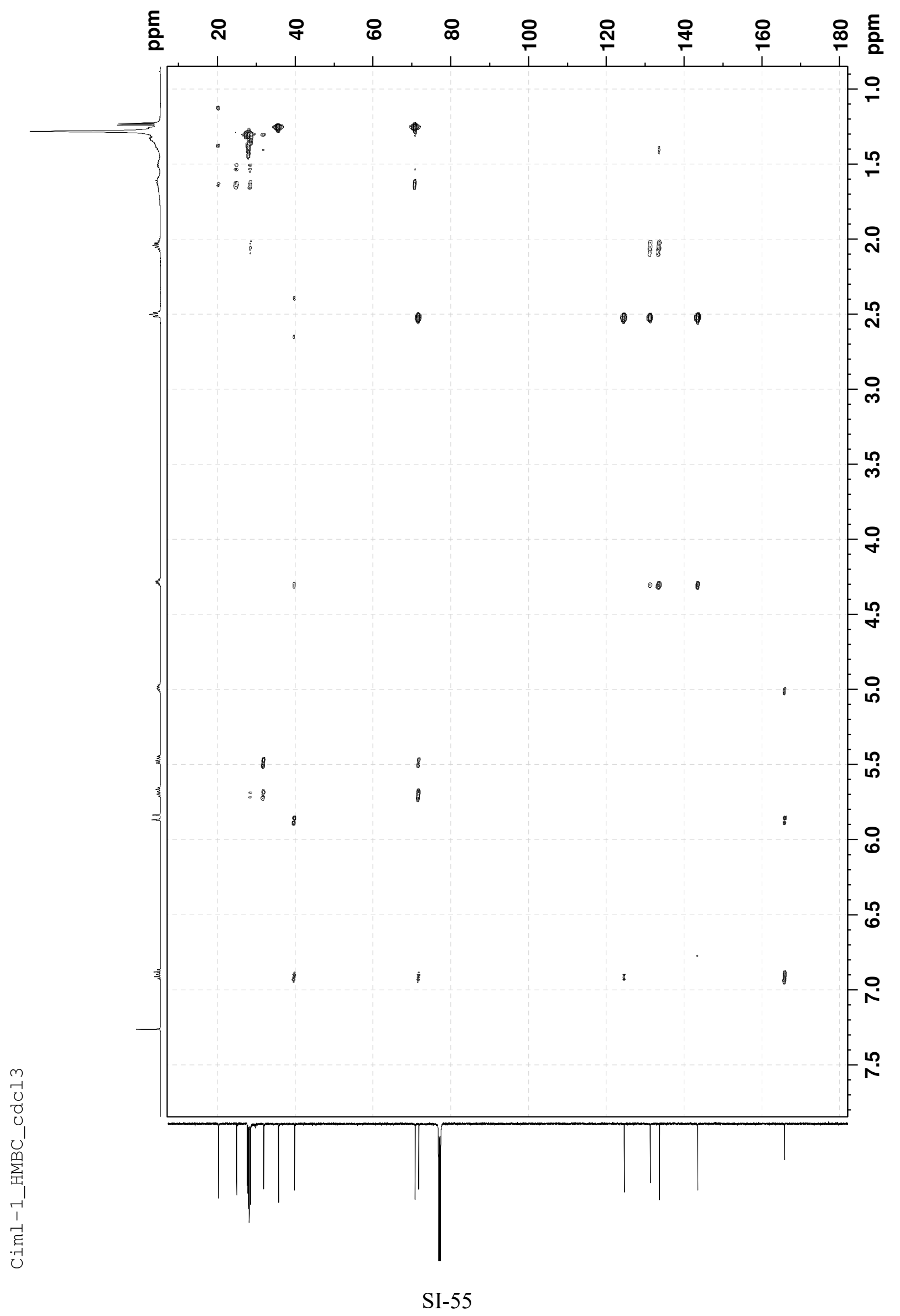


HSQC spectrum $\left(\mathrm{CDCl}_{3}\right)$ of CIML A (5)

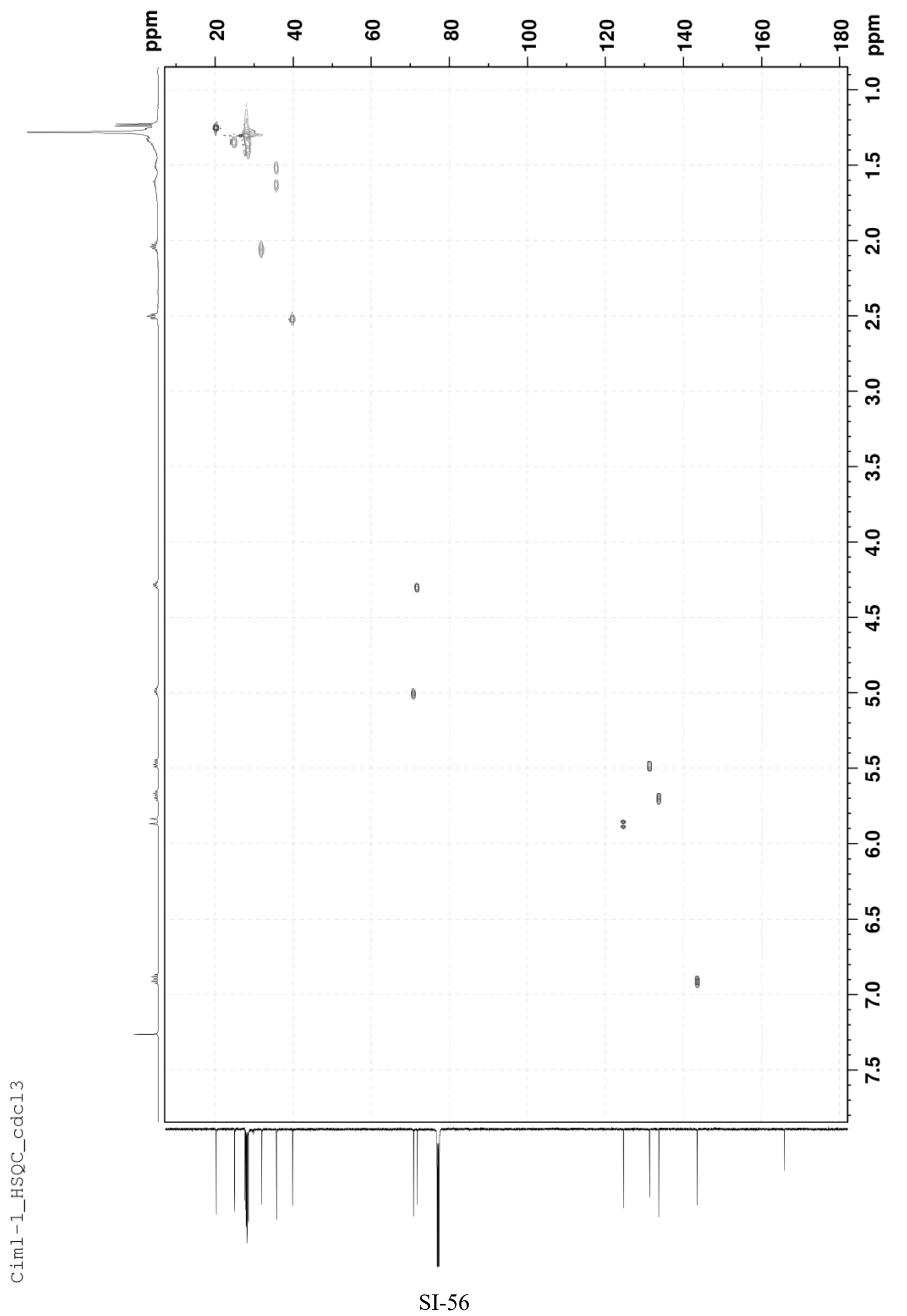


${ }^{1} \mathrm{H}$ NMR spectrum $\left(500 \mathrm{MHz}, \mathrm{CD}_{3} \mathrm{OD}\right)$ of CIML B (6)

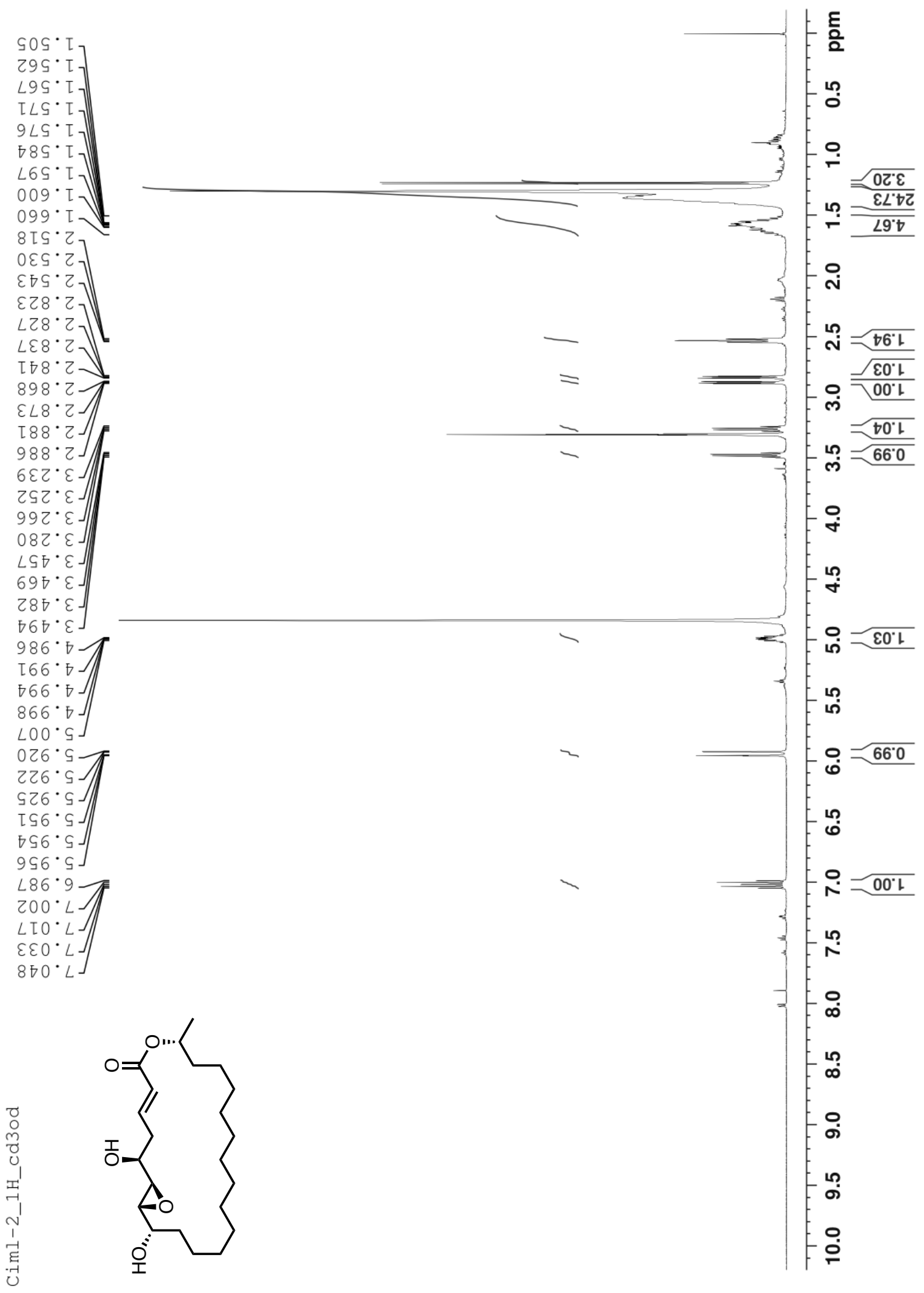


${ }^{13} \mathrm{C}$ NMR spectrum (125 MHz, $\left.\mathrm{CD}_{3} \mathrm{OD}\right)$ of CIML B (6)

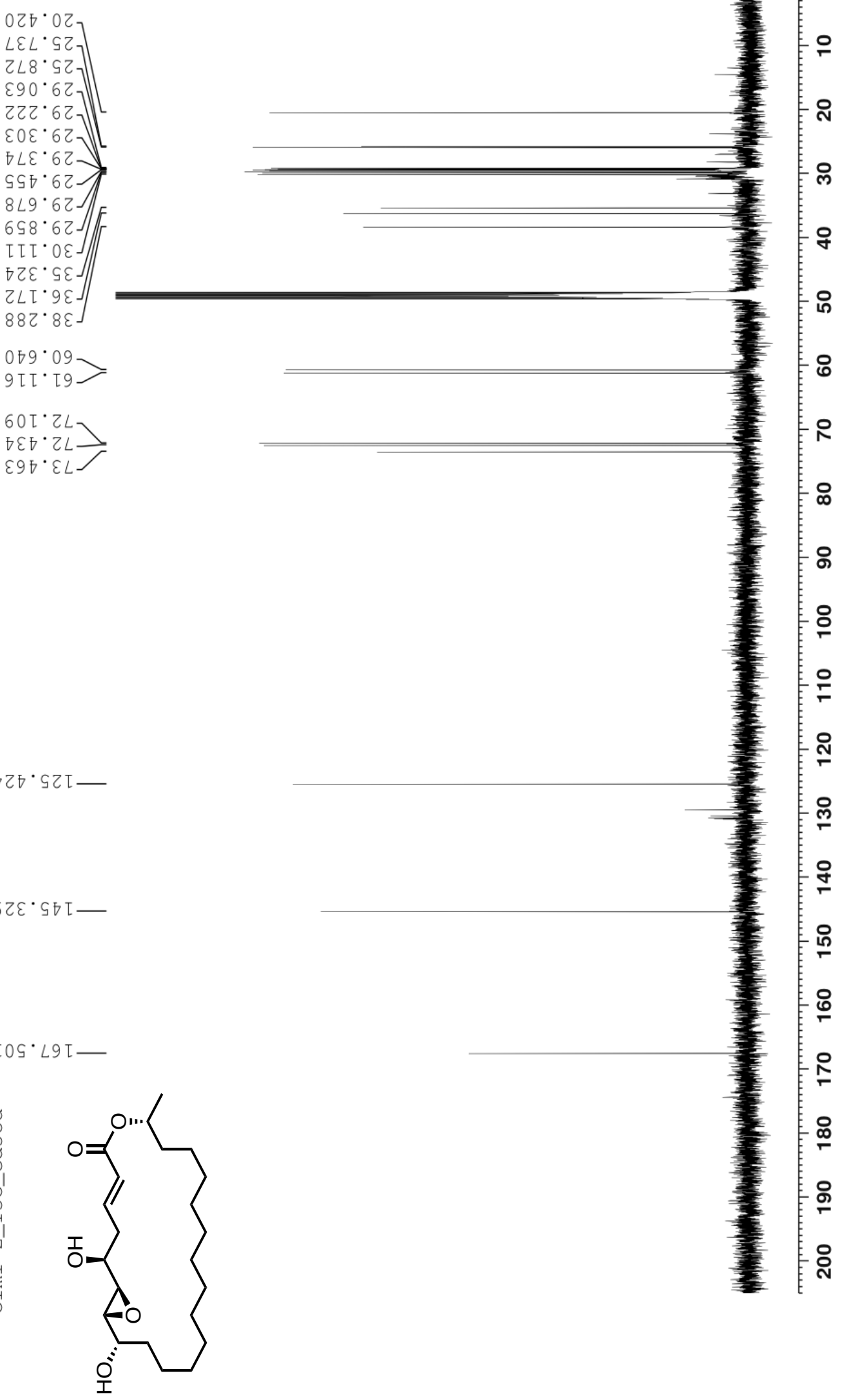


${ }^{1} \mathrm{H}-{ }^{1} \mathrm{H}$ COSY spectrum $\left(\mathrm{CD}_{3} \mathrm{OD}\right)$ of CIML B (6)

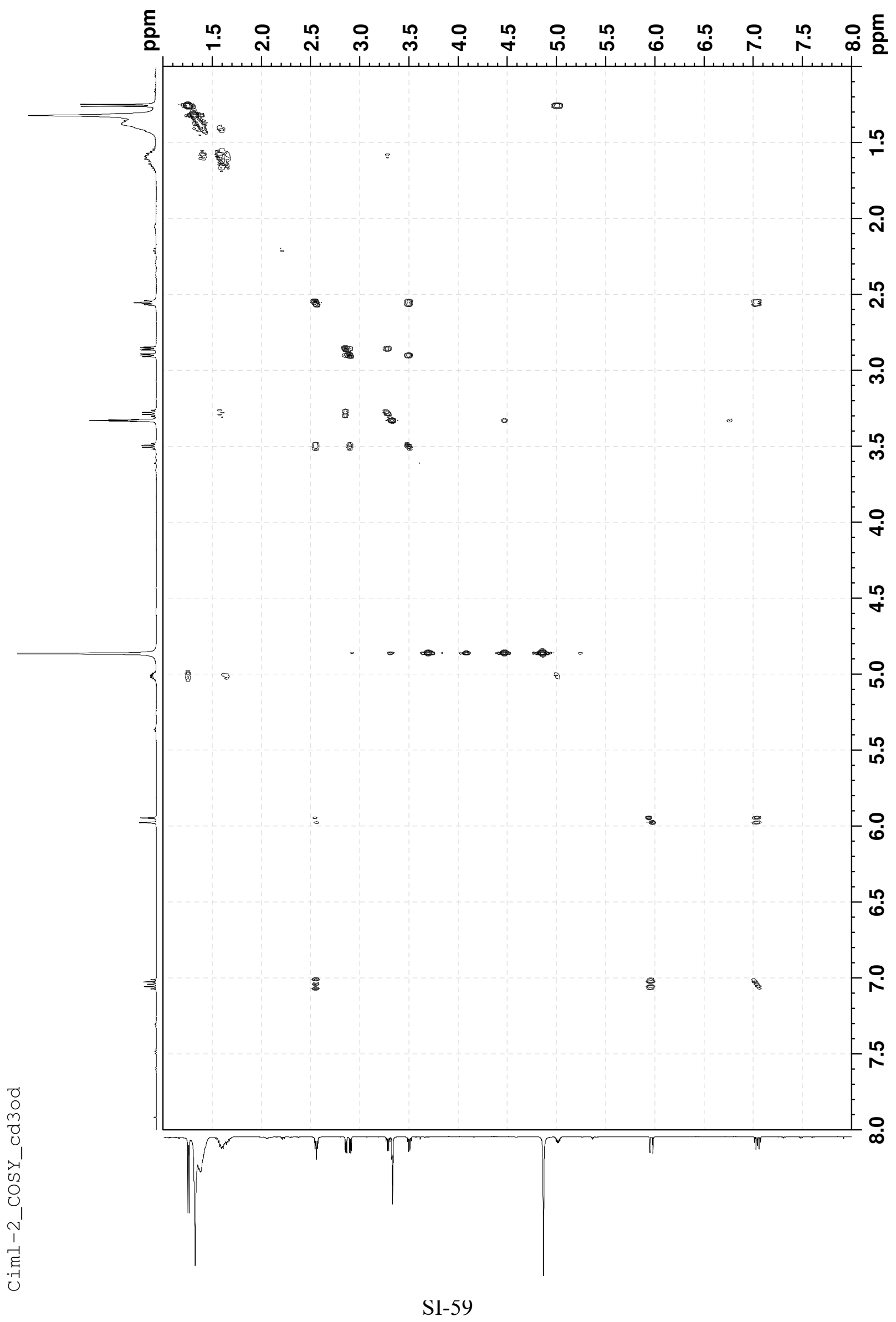


HMBC spectrum $\left(\mathrm{CD}_{3} \mathrm{OD}\right)$ of CIML B (6)

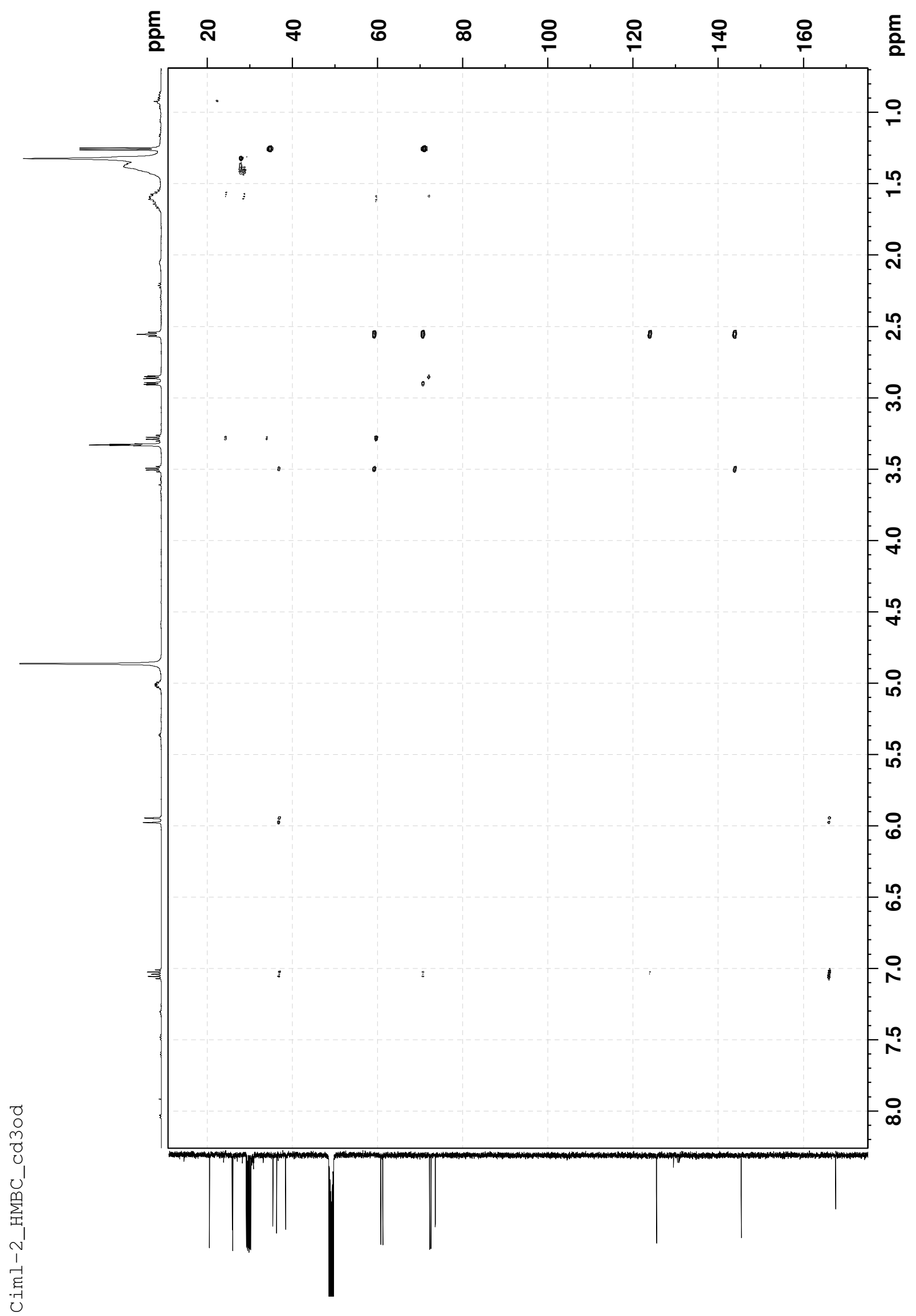


HSQC spectrum ( $\left.\mathrm{CD}_{3} \mathrm{OD}\right)$ of CIML B (6)

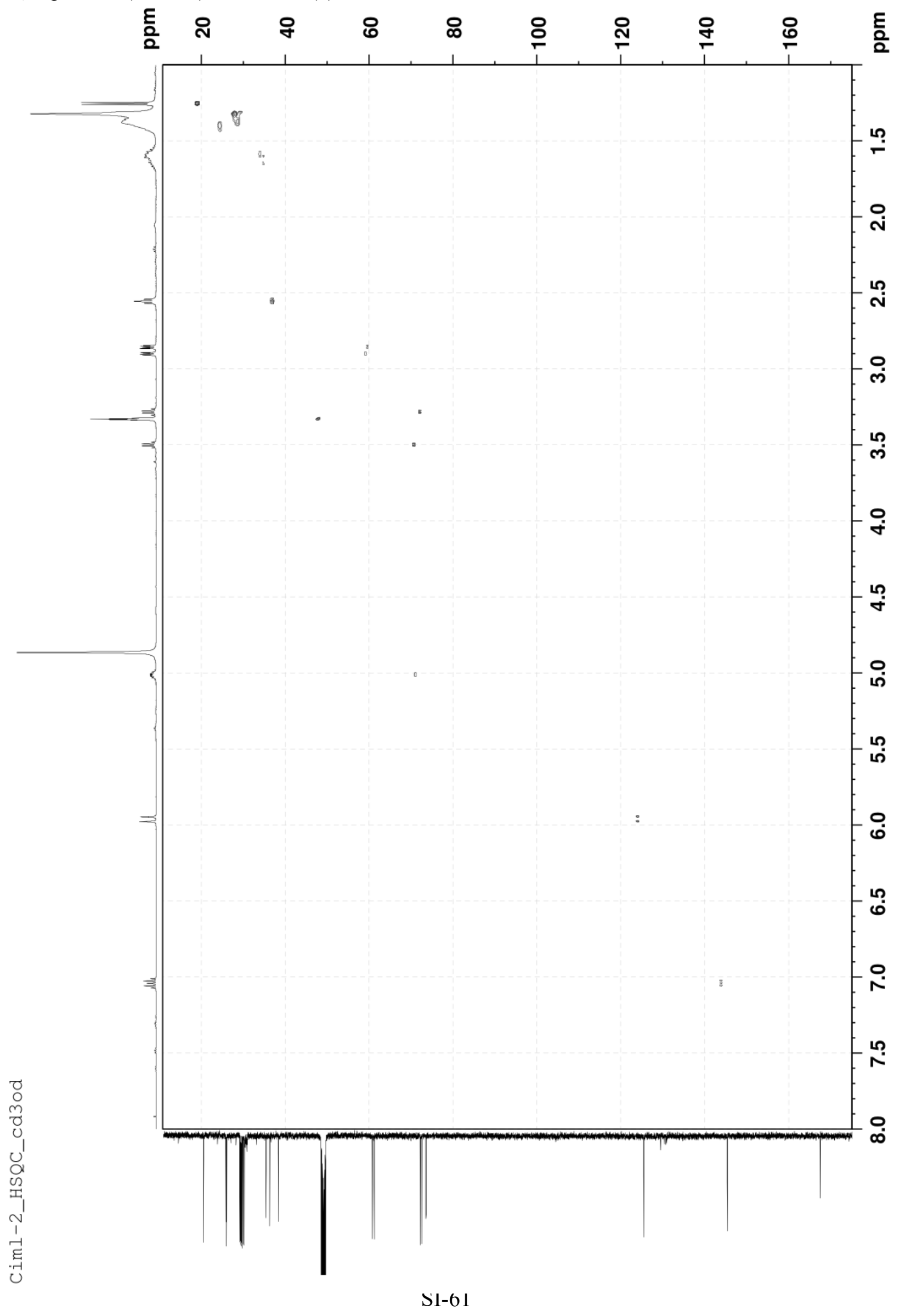


HSQC-TOCSY spectrum $\left(\mathrm{CD}_{3} \mathrm{OD}\right)$ of CIML B (6)

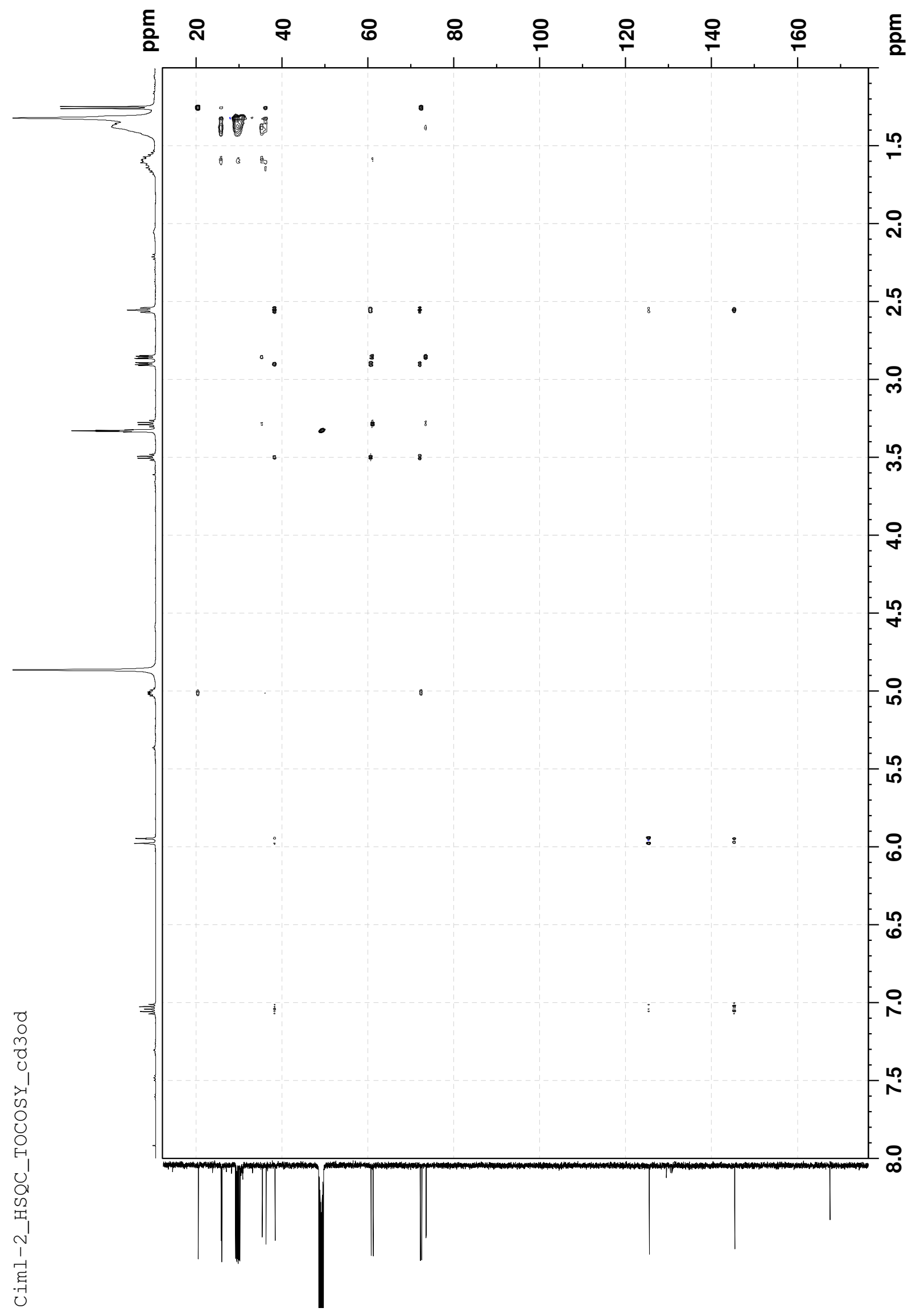


${ }^{1} \mathrm{H}$ NMR spectrum $\left(500 \mathrm{MHz}, \mathrm{CD}_{3} \mathrm{OD}\right)$ of CIML C (7)

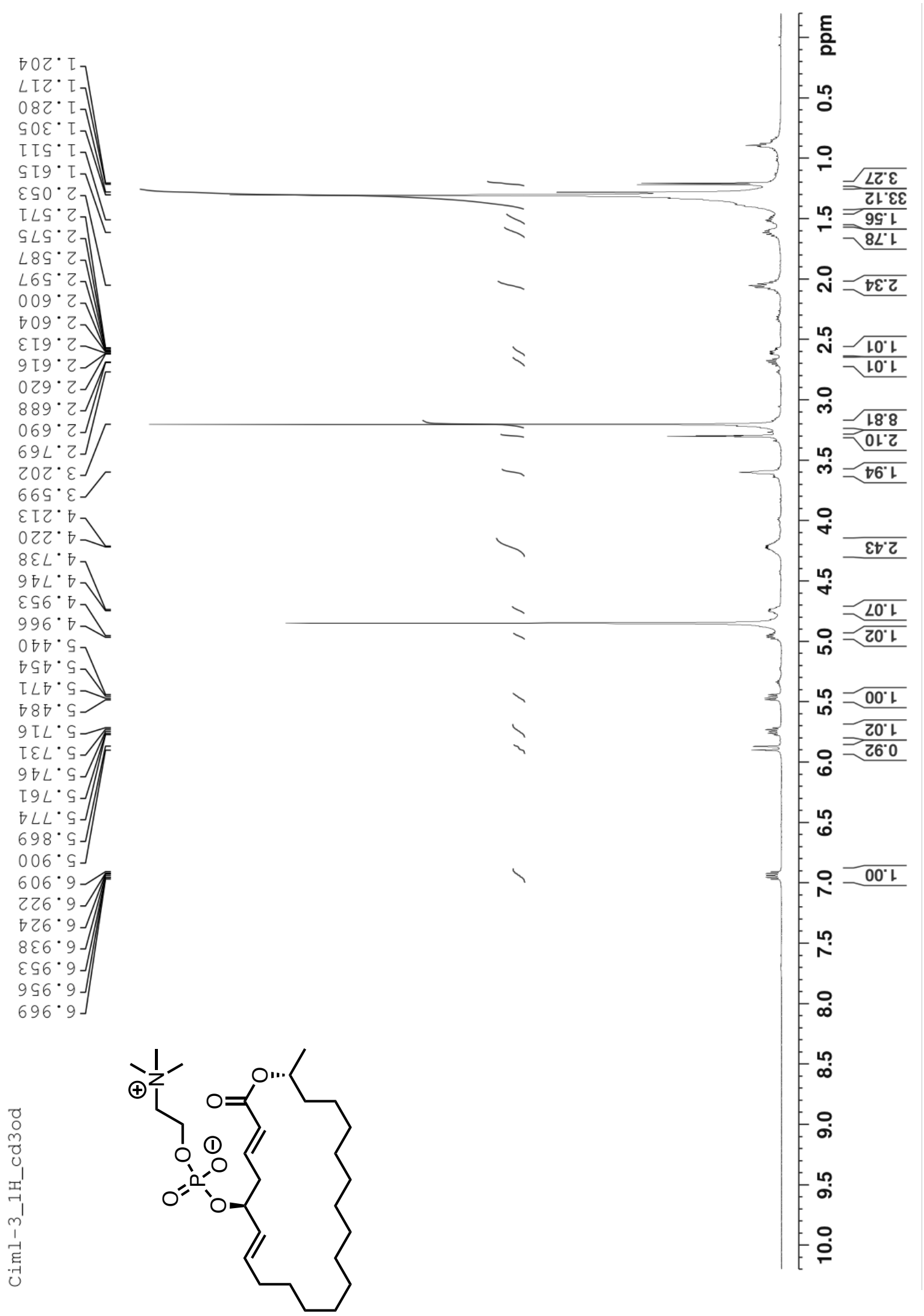


${ }^{13} \mathrm{C}$ NMR spectrum (125 MHz, $\left.\mathrm{CD}_{3} \mathrm{OD}\right)$ of CIML C (7)
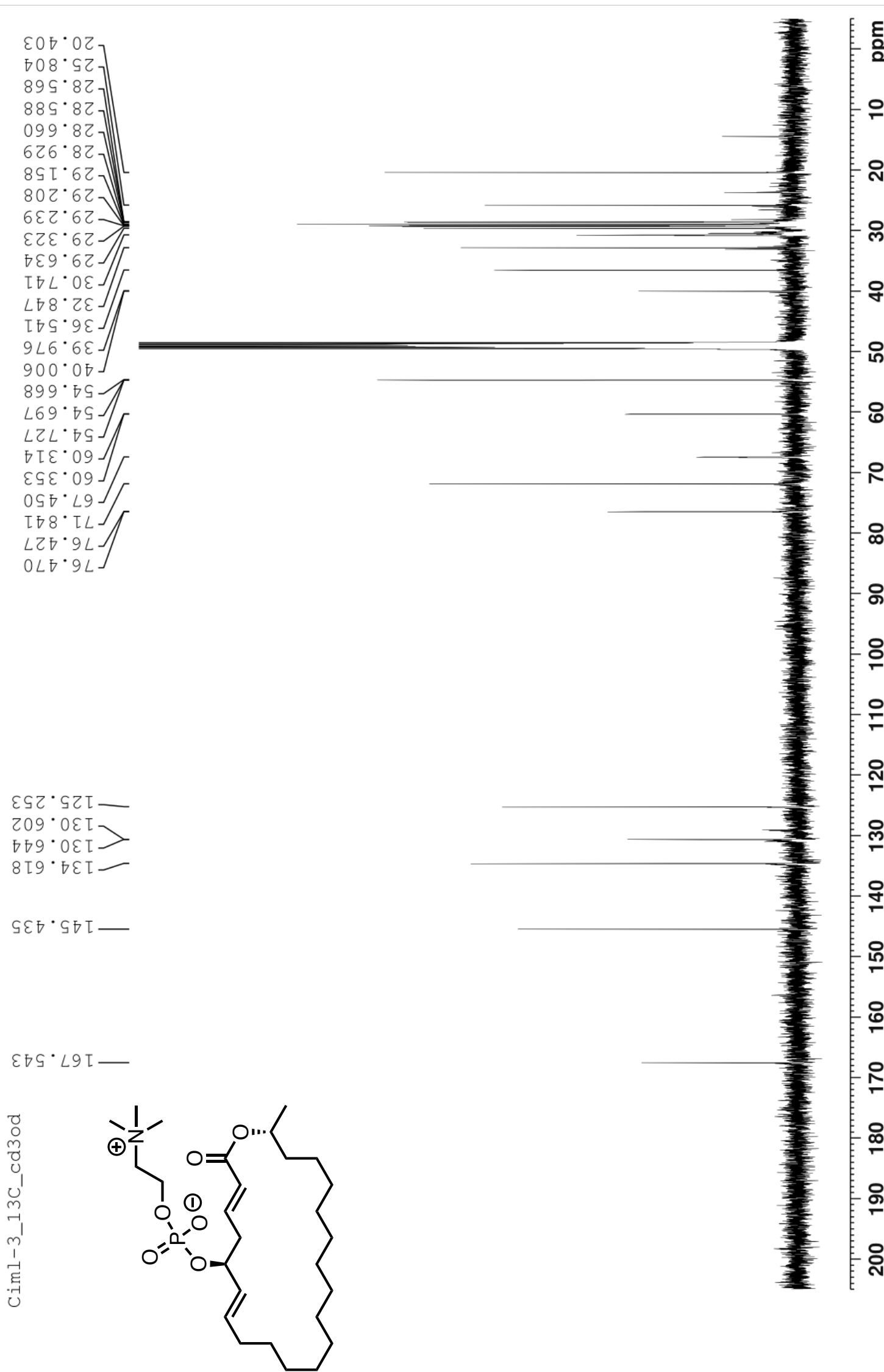
${ }^{1} \mathrm{H}-{ }^{1} \mathrm{H}$ COSY spectrum $\left(\mathrm{CD}_{3} \mathrm{OD}\right)$ of CIML C (7)

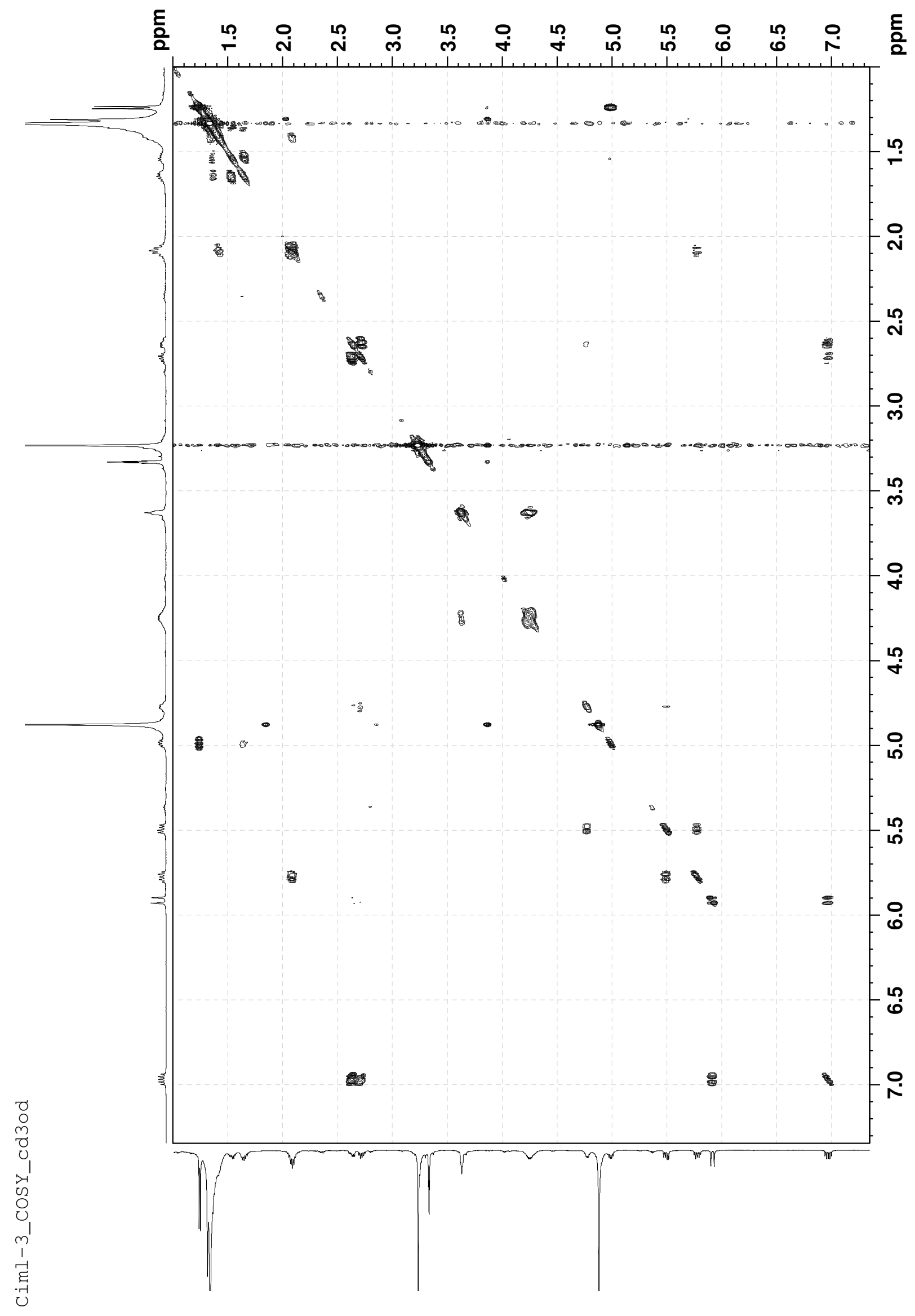


HMBC spectrum $\left(\mathrm{CD}_{3} \mathrm{OD}\right)$ of CIML C (7)

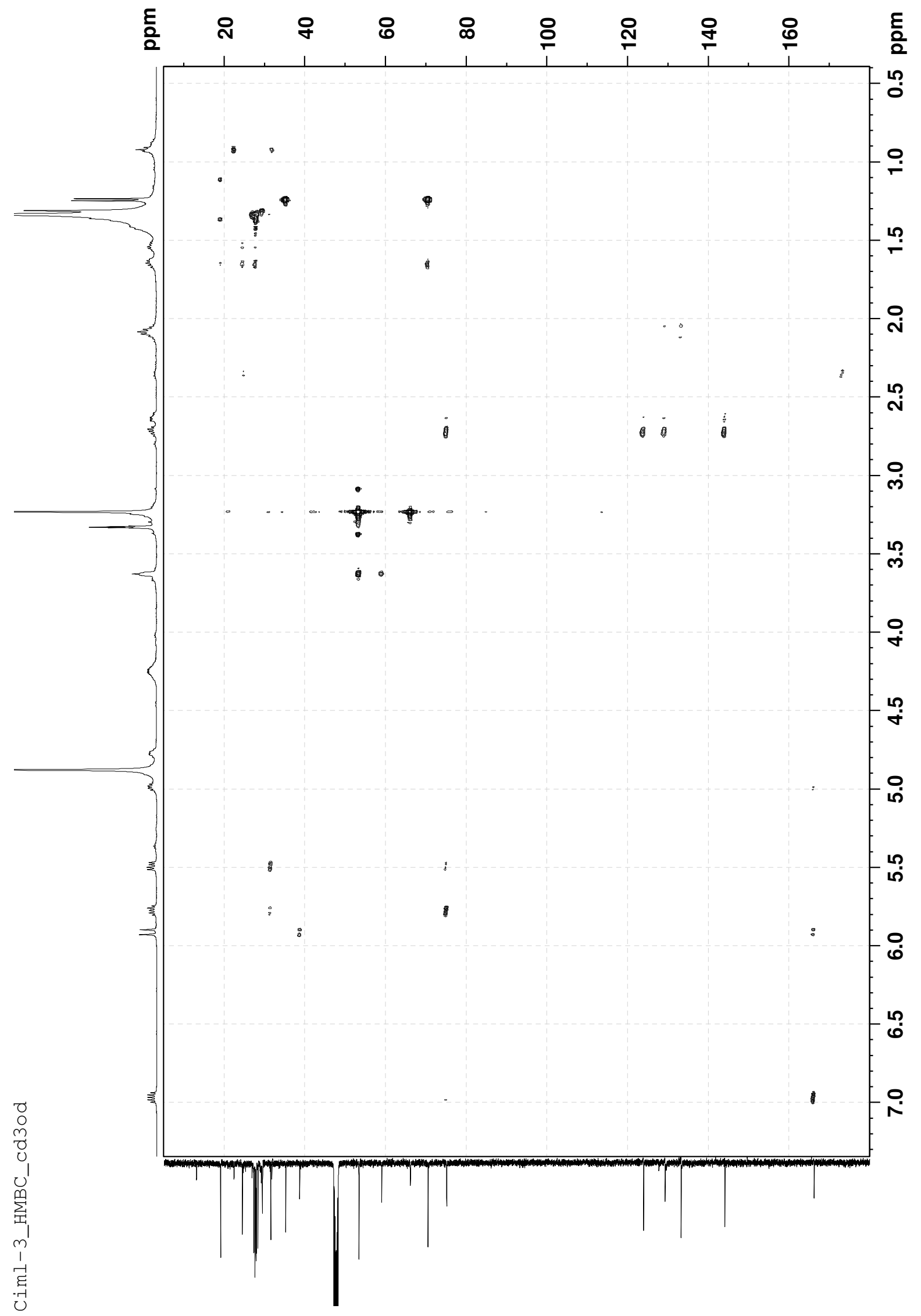


HSQC spectrum ( $\left.\mathrm{CD}_{3} \mathrm{OD}\right)$ of CIML C (7)

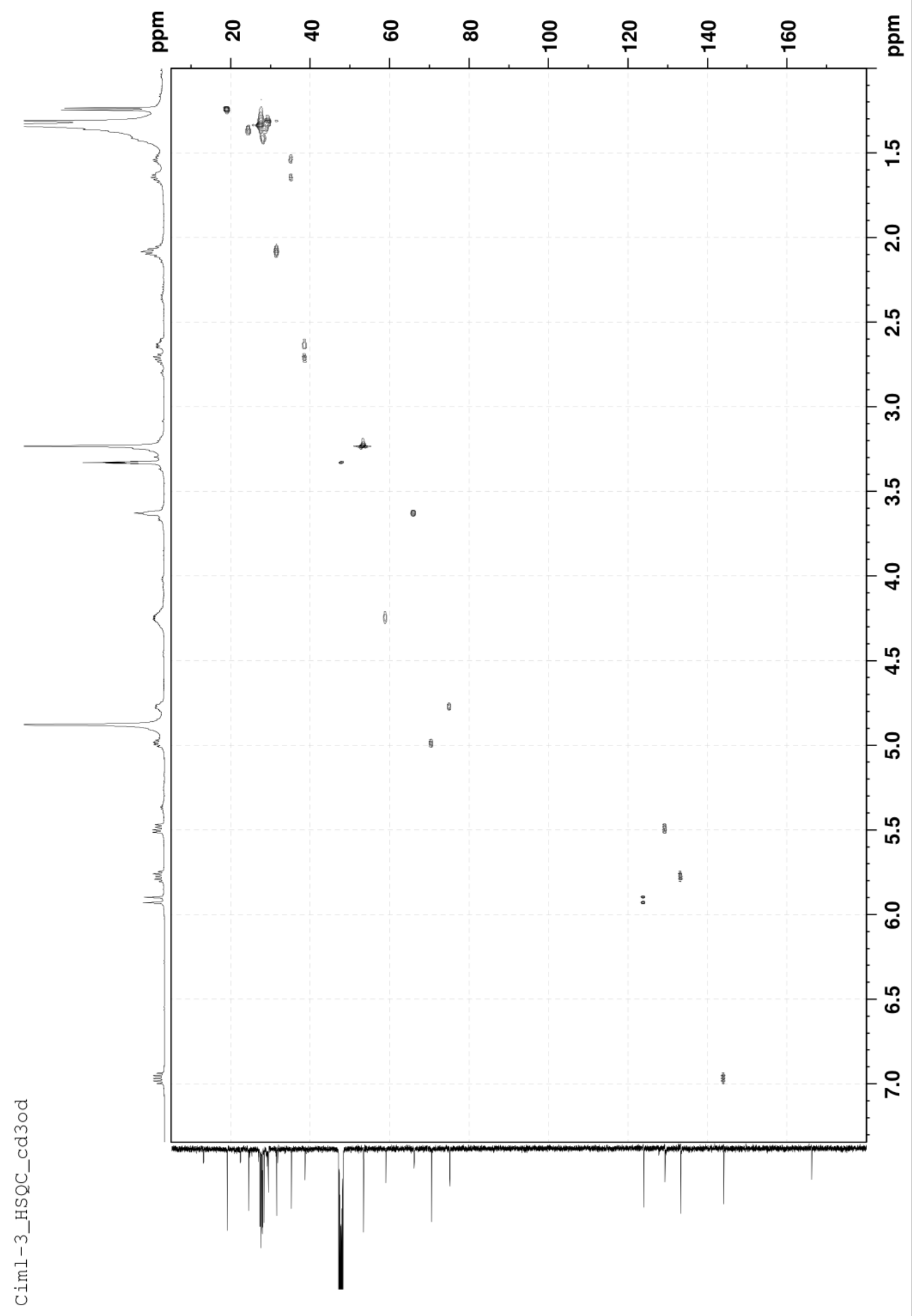


HSQC-TOCSY spectrum (CD $\left.{ }_{3} \mathrm{OD}\right)$ of CIML C (7)

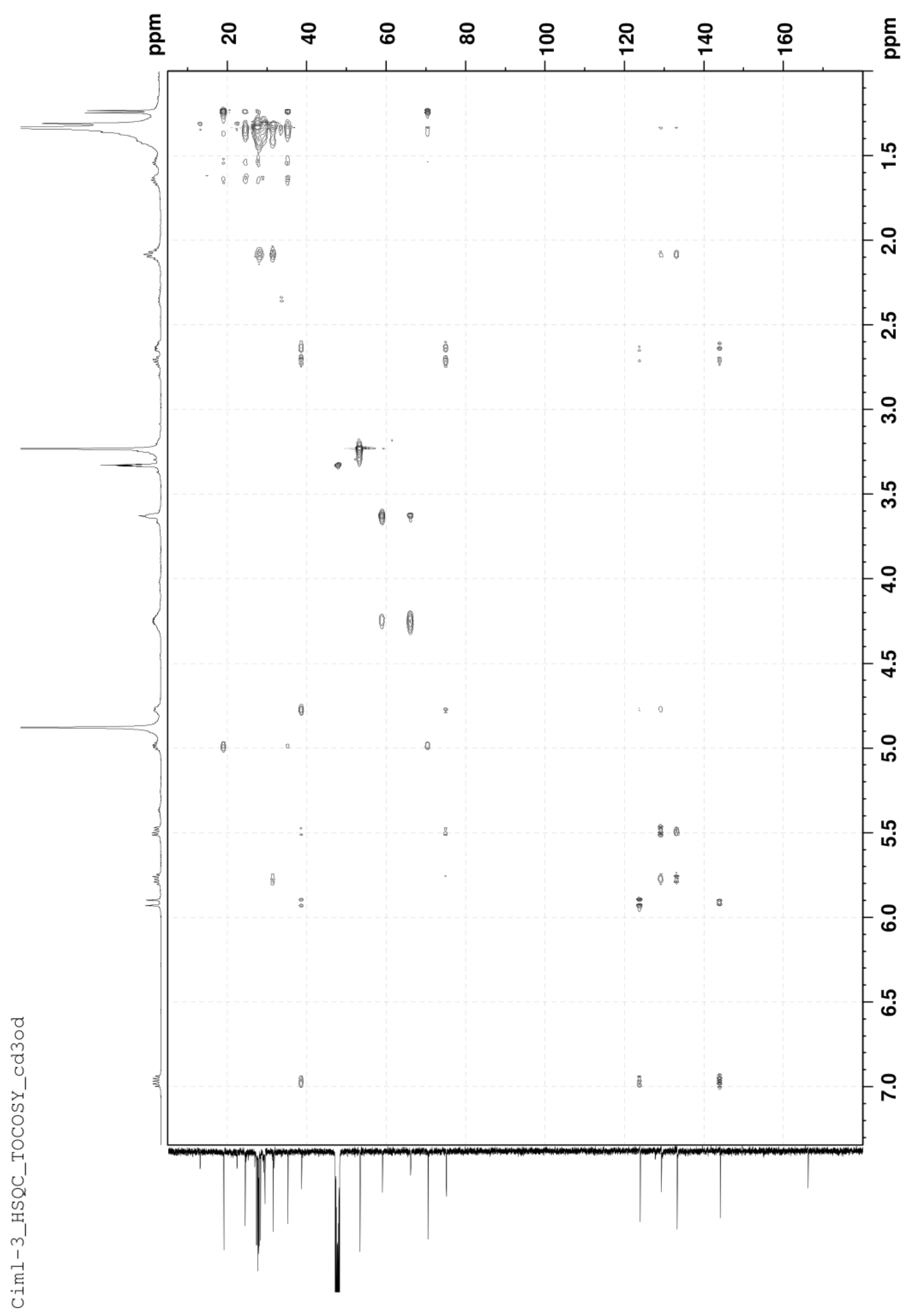


${ }^{1} \mathrm{H}$ NMR spectrum $\left(500 \mathrm{MHz}, \mathrm{CDCl}_{3}\left(20 \% \mathrm{CD}_{3} \mathrm{OD}\right)\right)$ of CIML D (8)

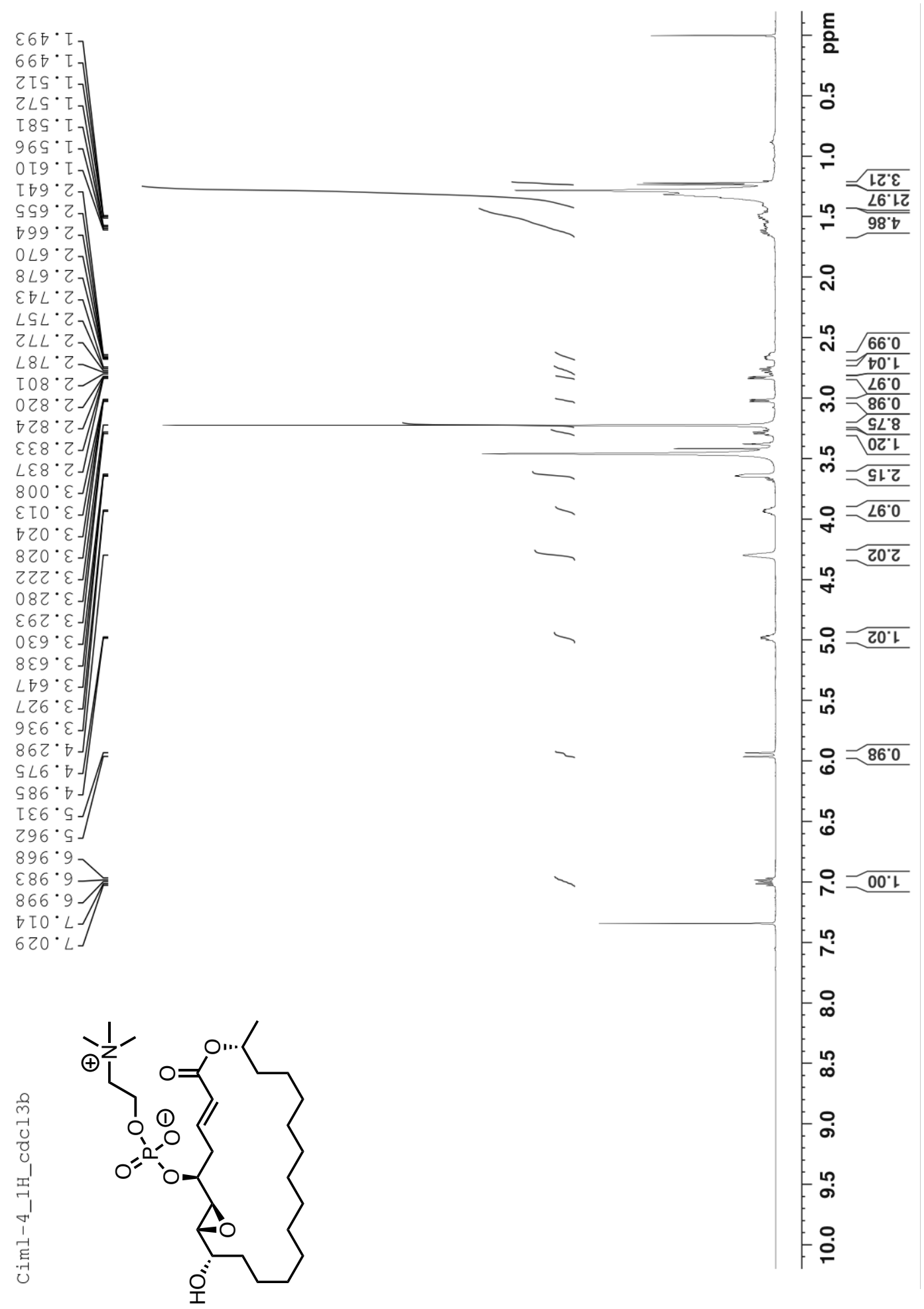


${ }^{13} \mathrm{C}$ NMR spectrum $\left(125 \mathrm{MHz}, \mathrm{CDCl}_{3}\left(20 \% \mathrm{CD}_{3} \mathrm{OD}\right)\right)$ of CIML D (8)

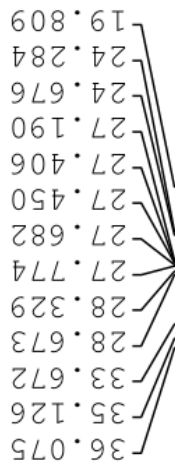

GLO. $9 \varepsilon$

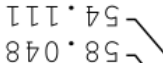

960.89

ธ28.85

ह98.85

हระ.09 88.99

$280^{\circ}$. L $L$

IZI. ${ }^{\circ} L$

OES. SLJ

$\forall L S^{\circ} S L J$

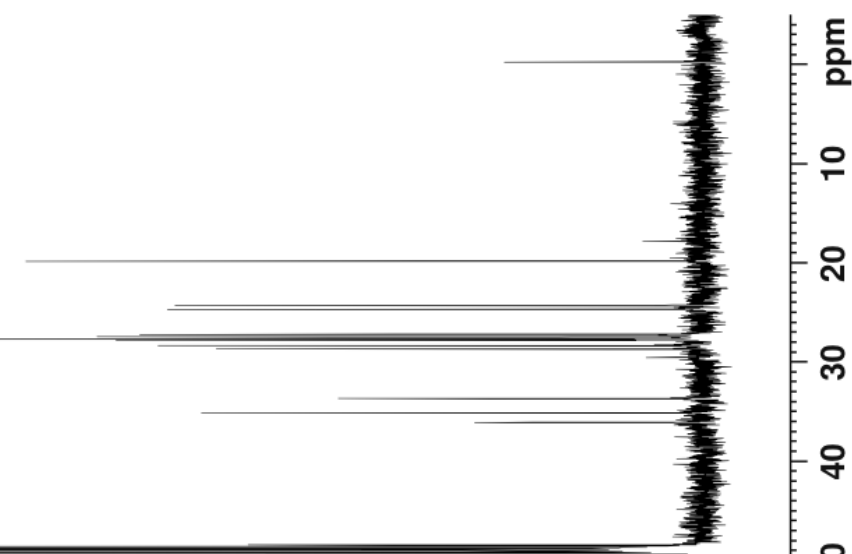

요

웅

웅

$\infty$

8

으

음

กิ

으

\&

오 운

8

ISO.99I-

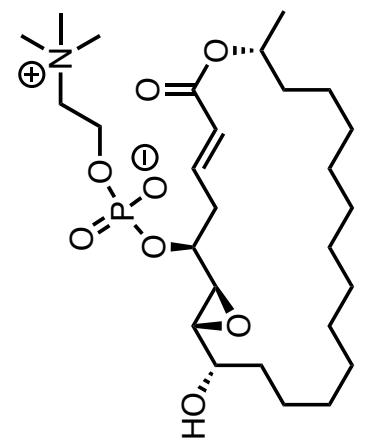


${ }^{1} \mathrm{H}-{ }^{1} \mathrm{H}$ COSY spectrum $\left(\mathrm{CDCl}_{3}\left(20 \% \mathrm{CD}_{3} \mathrm{OD}\right)\right)$ of CIML D (8)

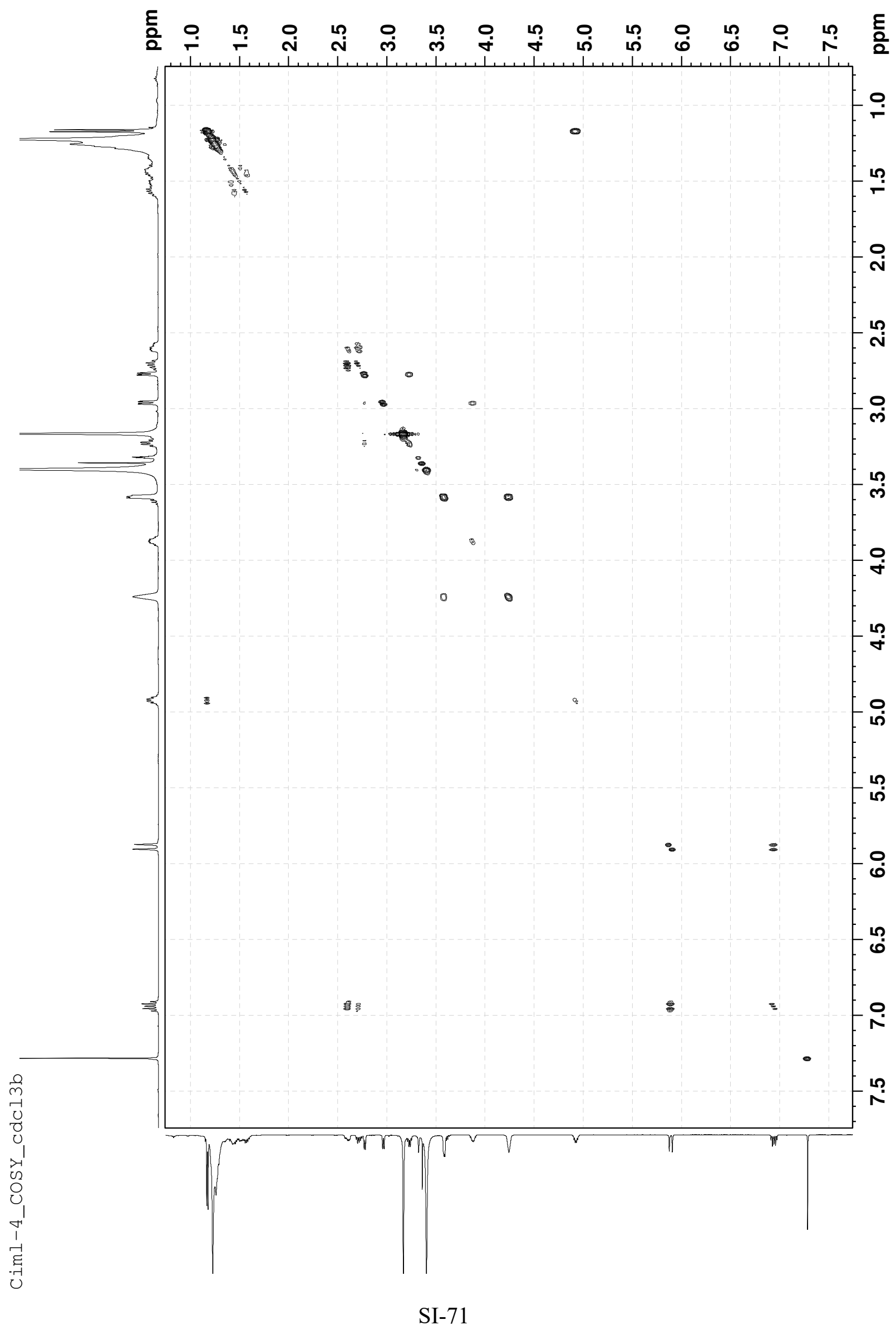


HMBC spectrum $\left(\mathrm{CDCl}_{3}\left(20 \% \mathrm{CD}_{3} \mathrm{OD}\right)\right)$ of CIML D (8)

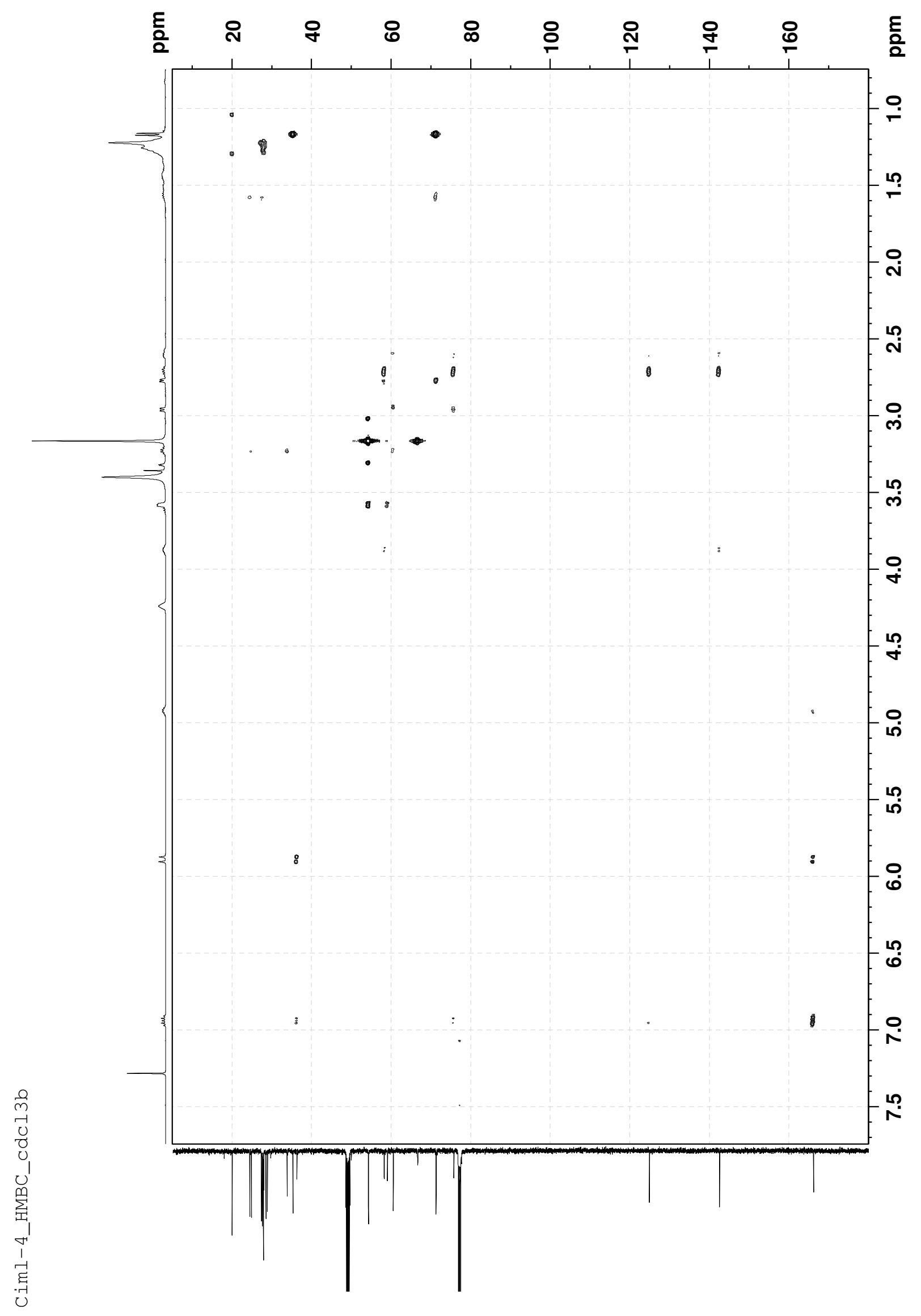


HSQC spectrum $\left(\mathrm{CDCl}_{3}\left(20 \% \mathrm{CD}_{3} \mathrm{OD}\right)\right)$ of CIML D (8)

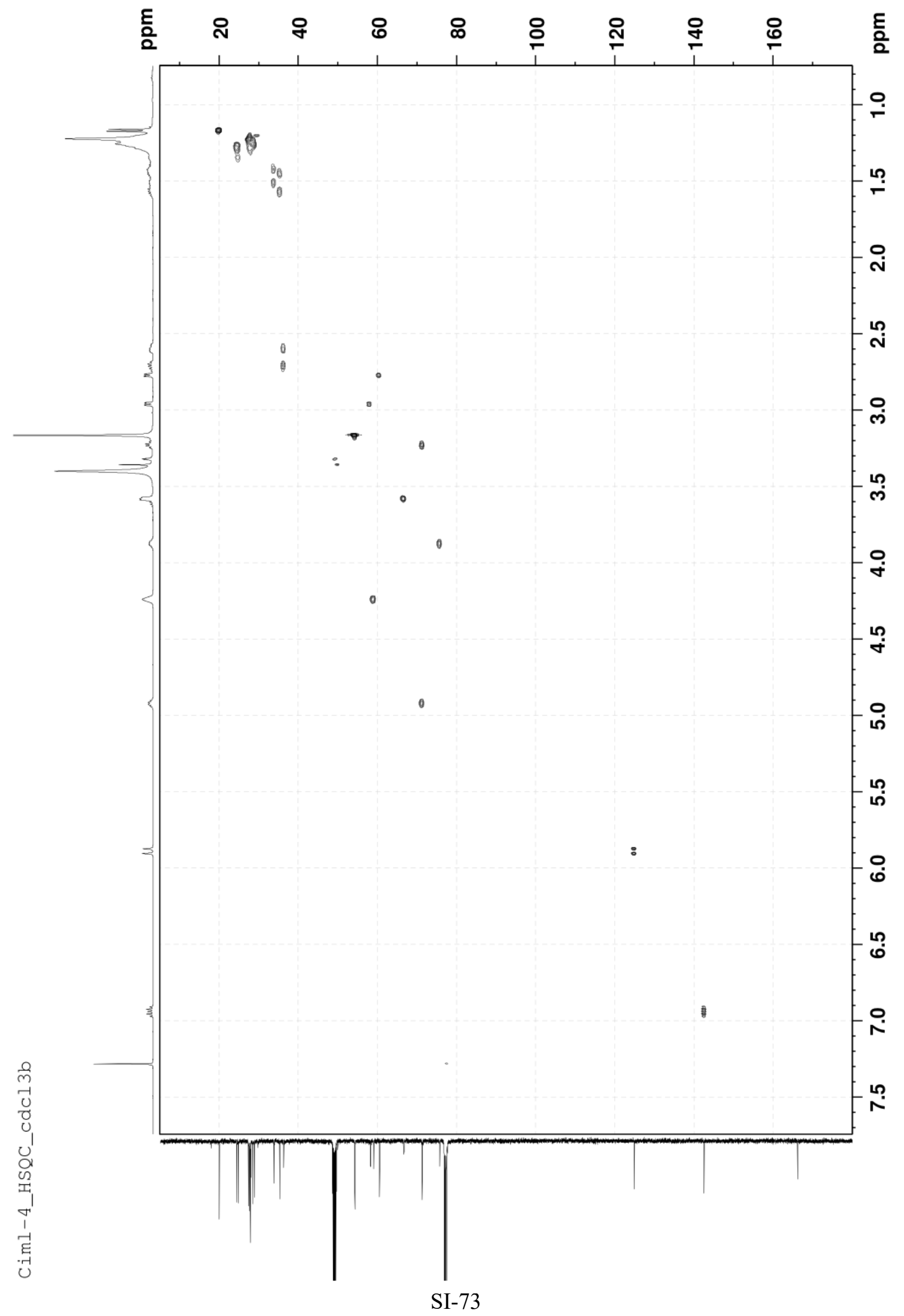


${ }^{1} \mathrm{H}$ NMR spectrum $\left(500 \mathrm{MHz}, \mathrm{CD}_{3} \mathrm{OD}\right)$ of 9

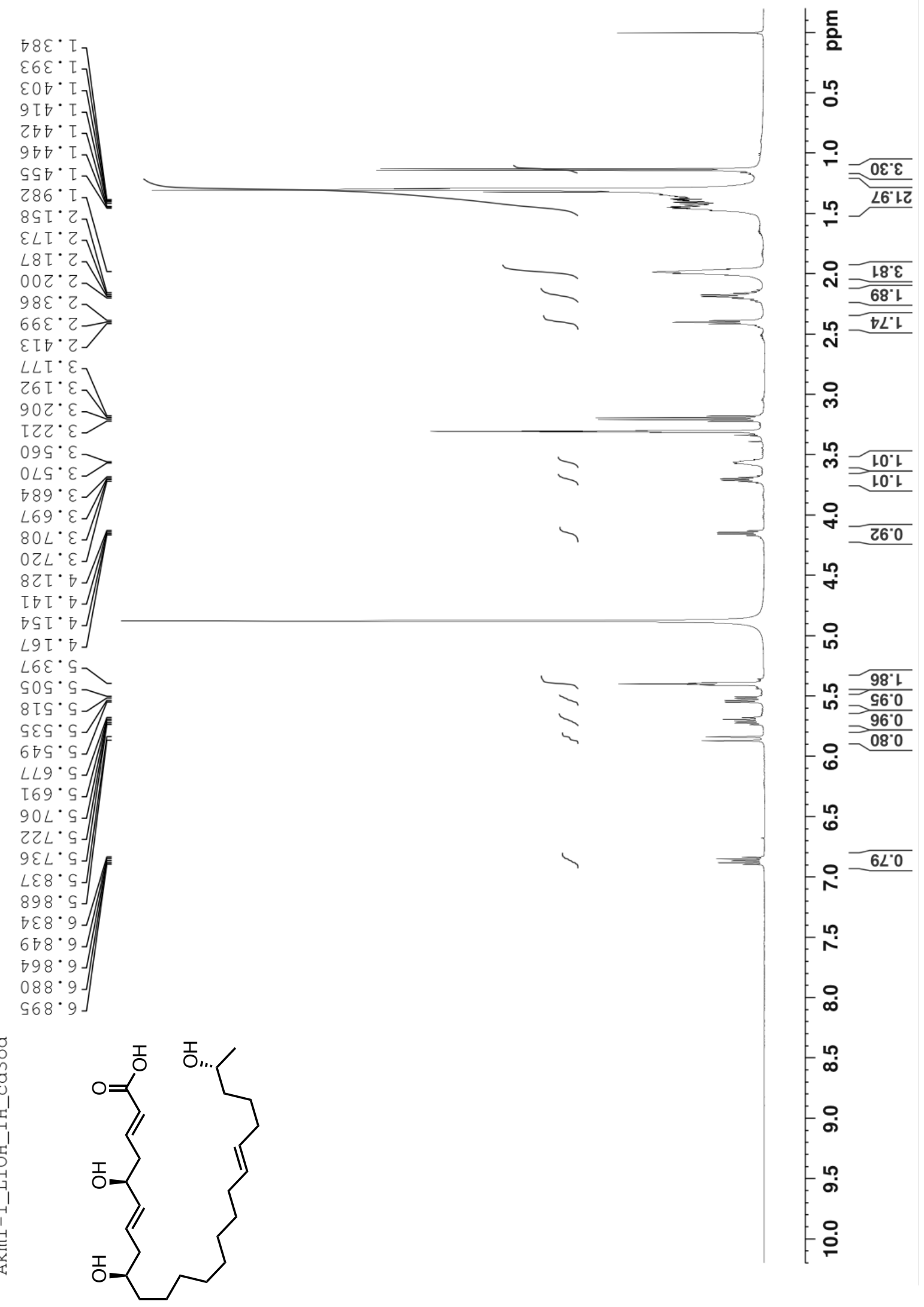


${ }^{1} \mathrm{H}$ NMR spectrum $\left(500 \mathrm{MHz}, \mathrm{CDCl}_{3}\right)$ of $\mathbf{1 0}$

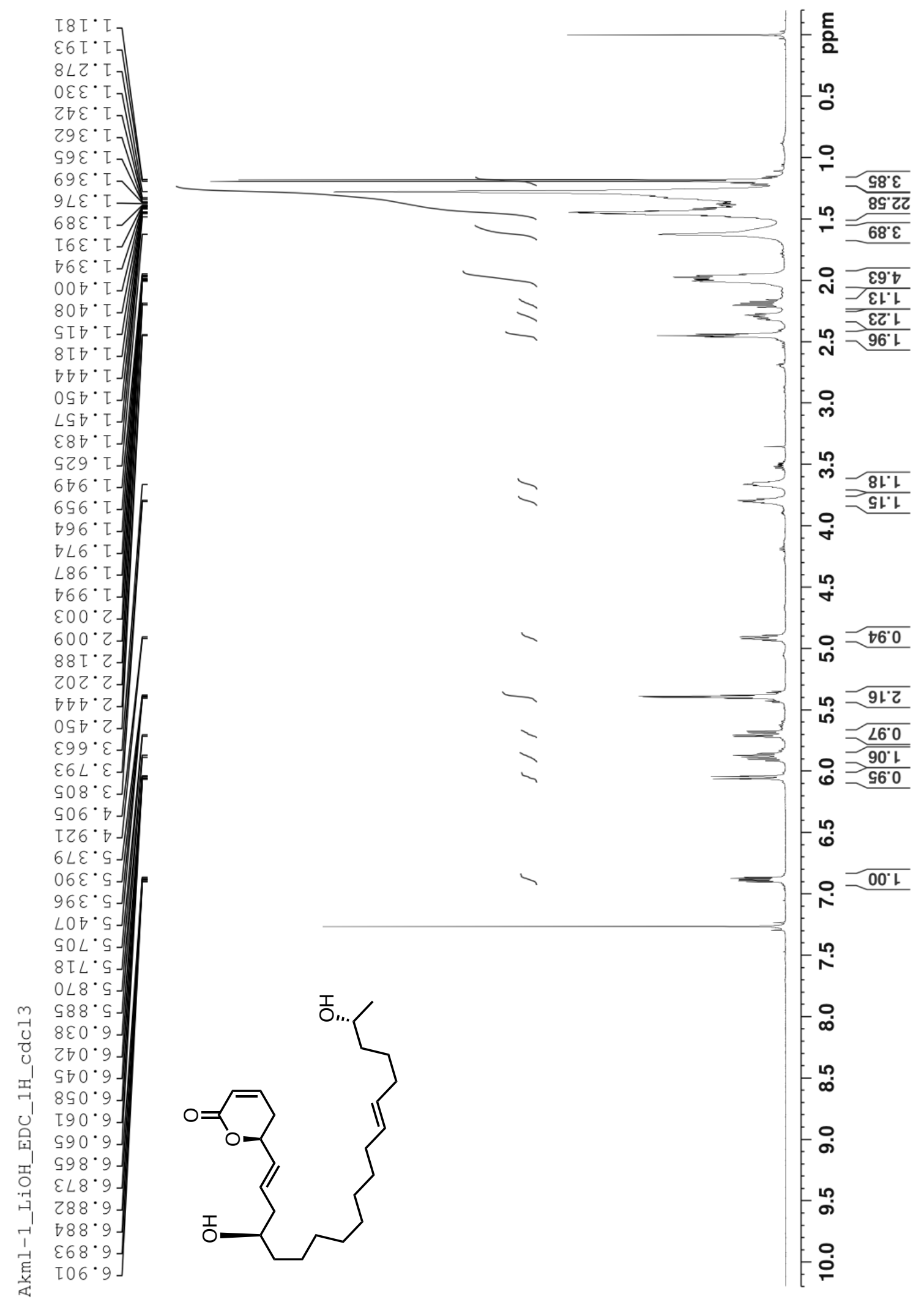


${ }^{13} \mathrm{C}$ NMR spectrum (125 MHz, $\left.\mathrm{CDCl}_{3}\right)$ of $\mathbf{1 0}$

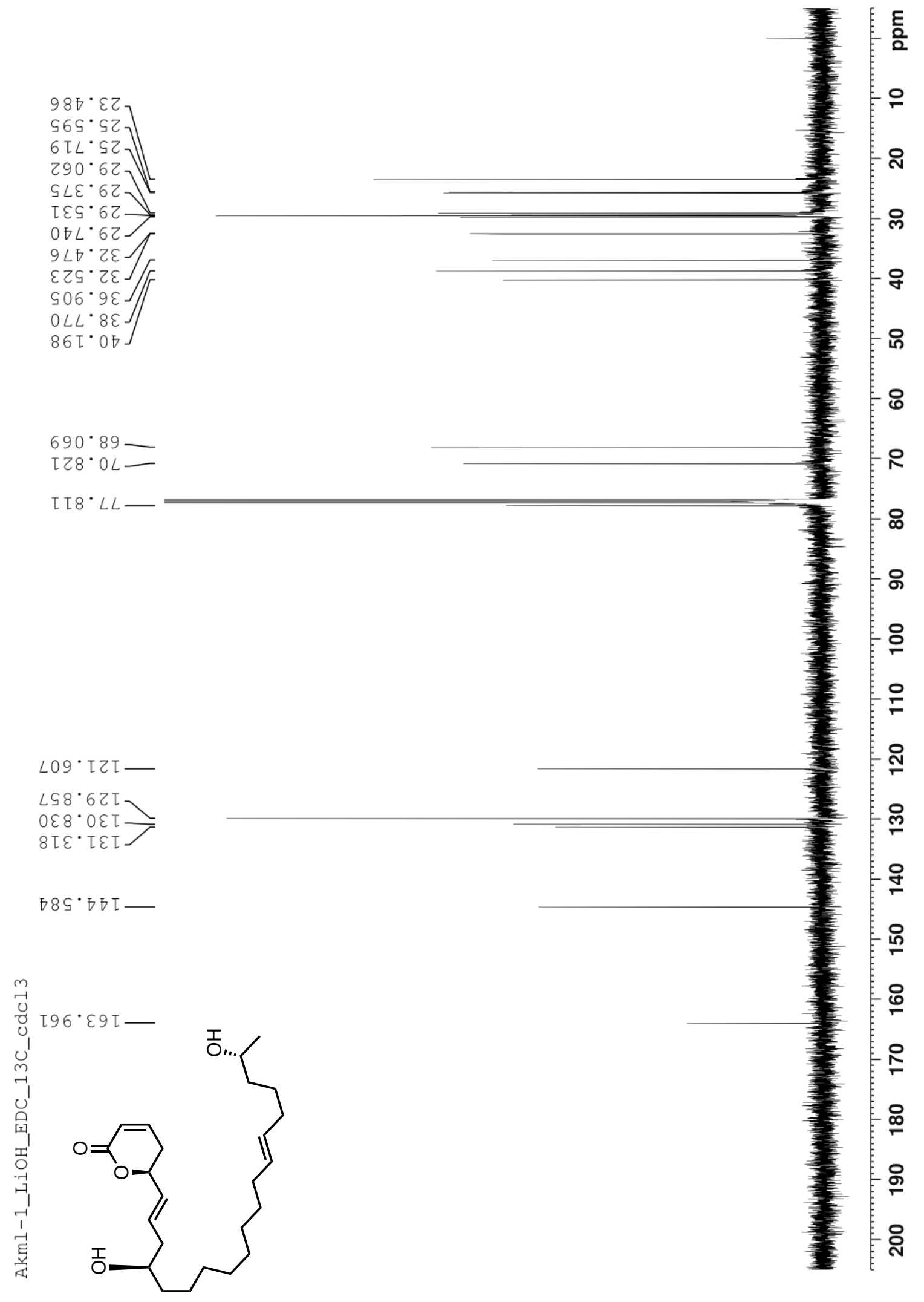


${ }^{1} \mathrm{H}-{ }^{1} \mathrm{H}$ COSY spectrum $\left(\mathrm{CDCl}_{3}\right)$ of $\mathbf{1 0}$

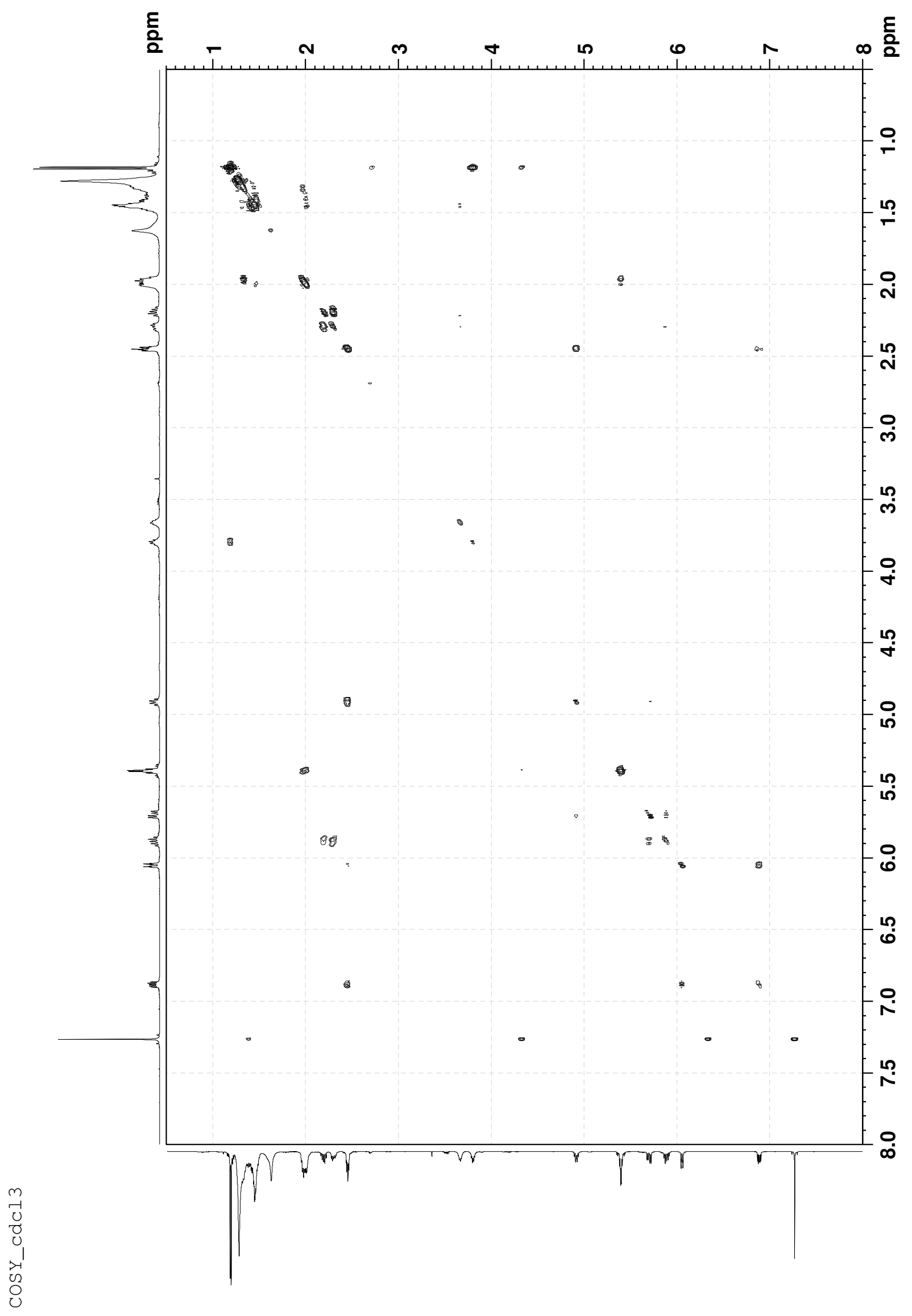


HMBC spectrum $\left(\mathrm{CDCl}_{3}\right)$ of $\mathbf{1 0}$

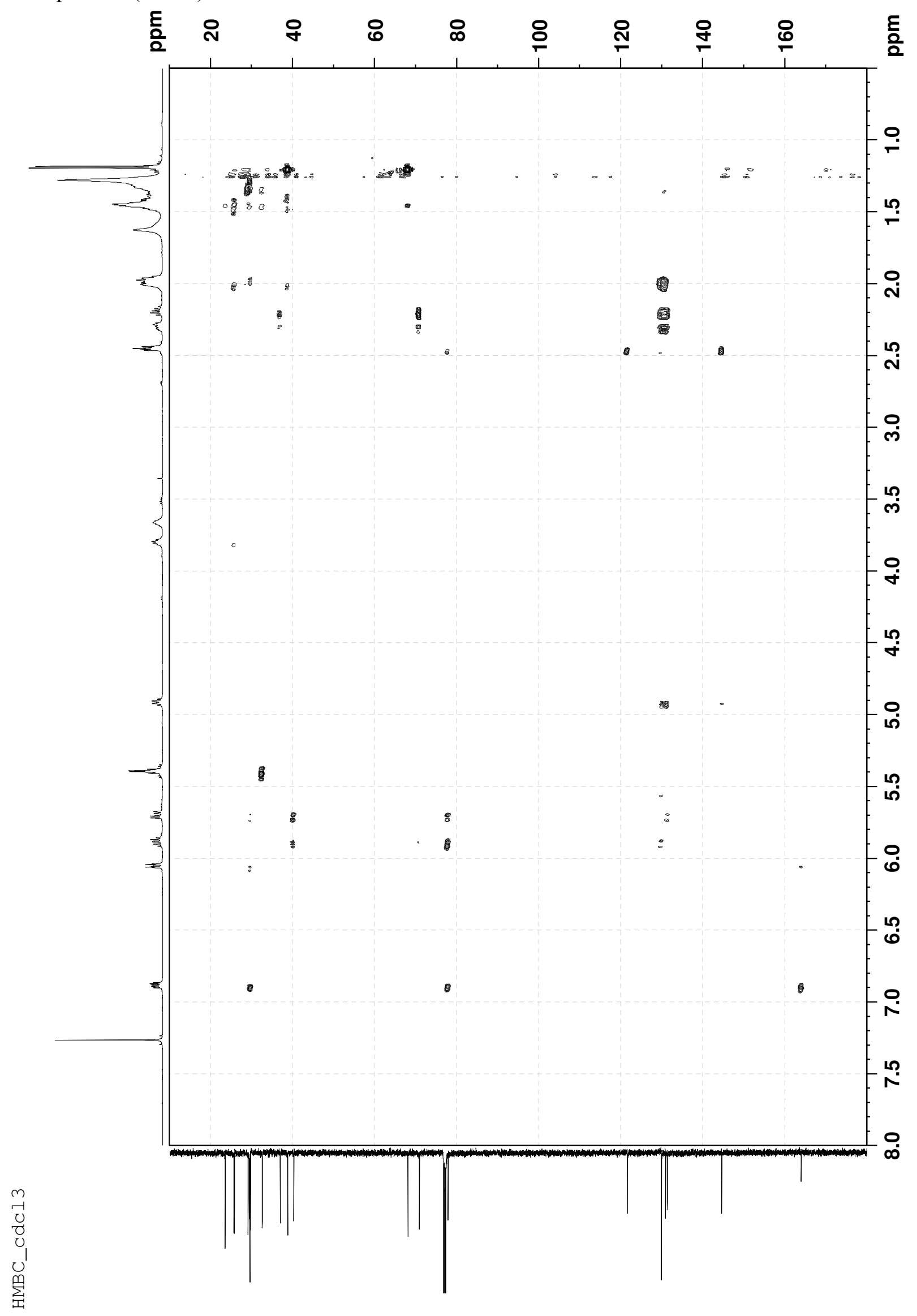


HSQC spectrum $\left(\mathrm{CDCl}_{3}\right)$ of $\mathbf{1 0}$

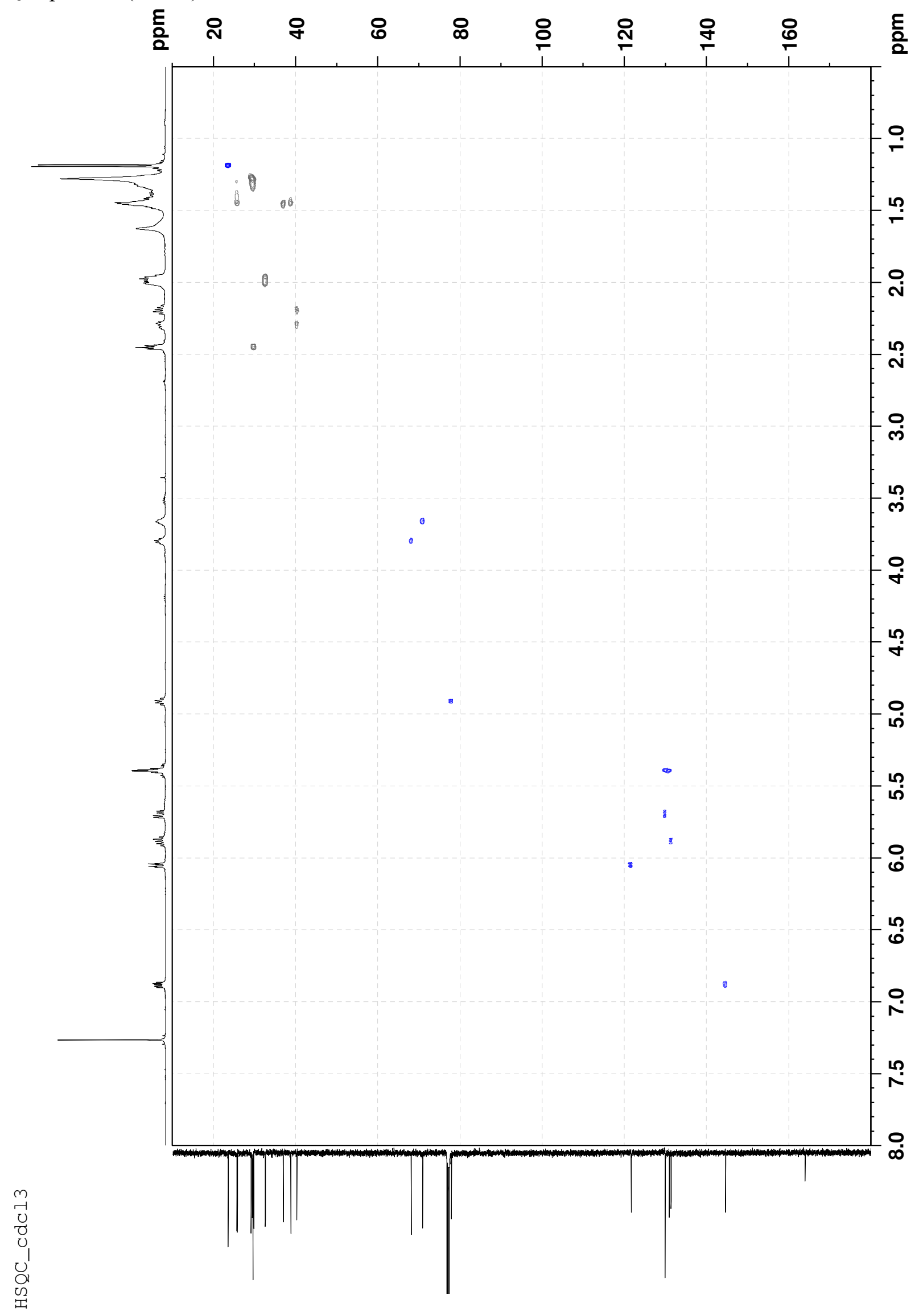


NOESY spectrum $\left(\mathrm{CDCl}_{3}\right)$ of $\mathbf{1 0}$

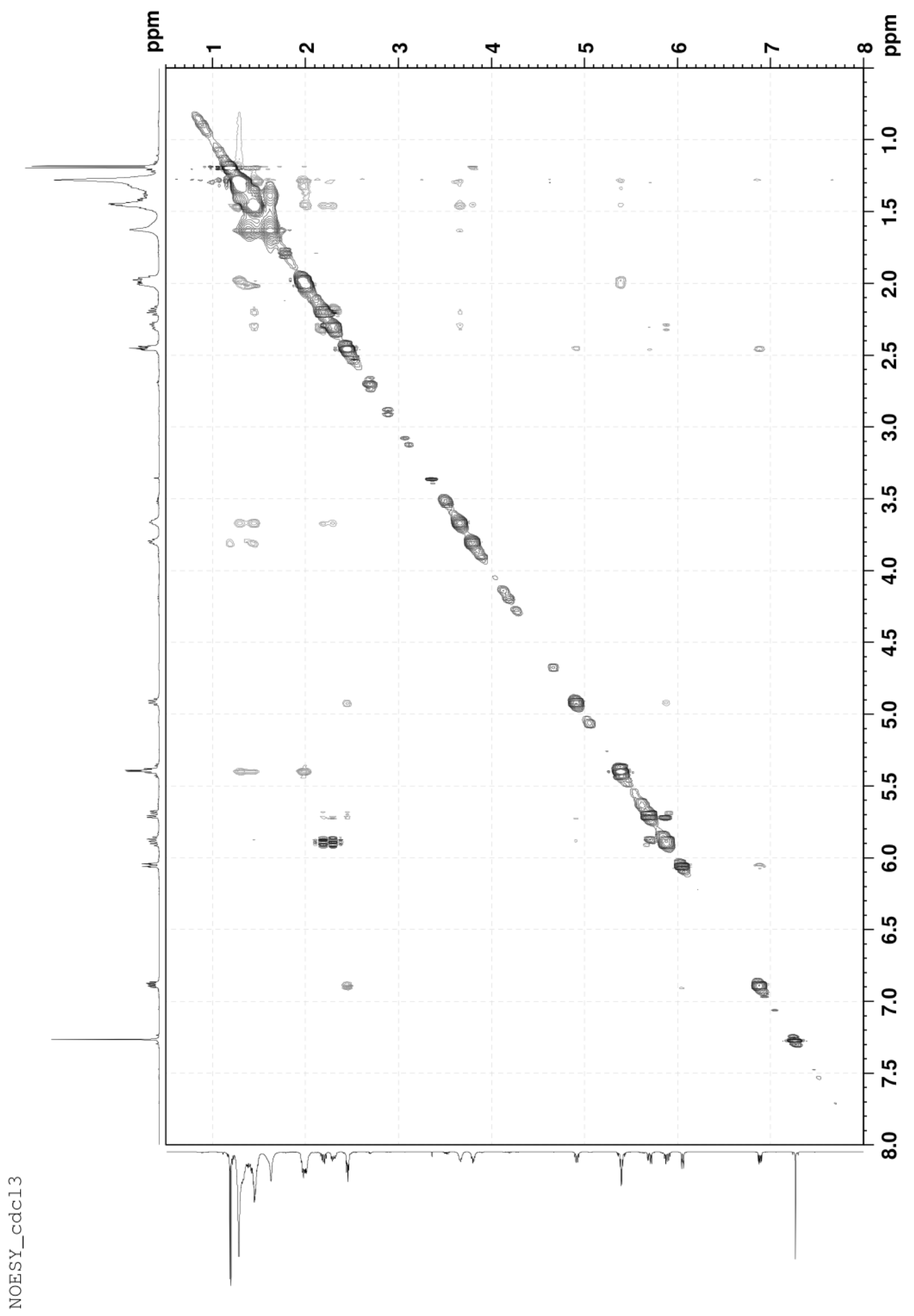


${ }^{1} \mathrm{H}$ NMR spectrum $\left(500 \mathrm{MHz}, \mathrm{CDCl}_{3}\right)$ of $\mathbf{1 1 a}$

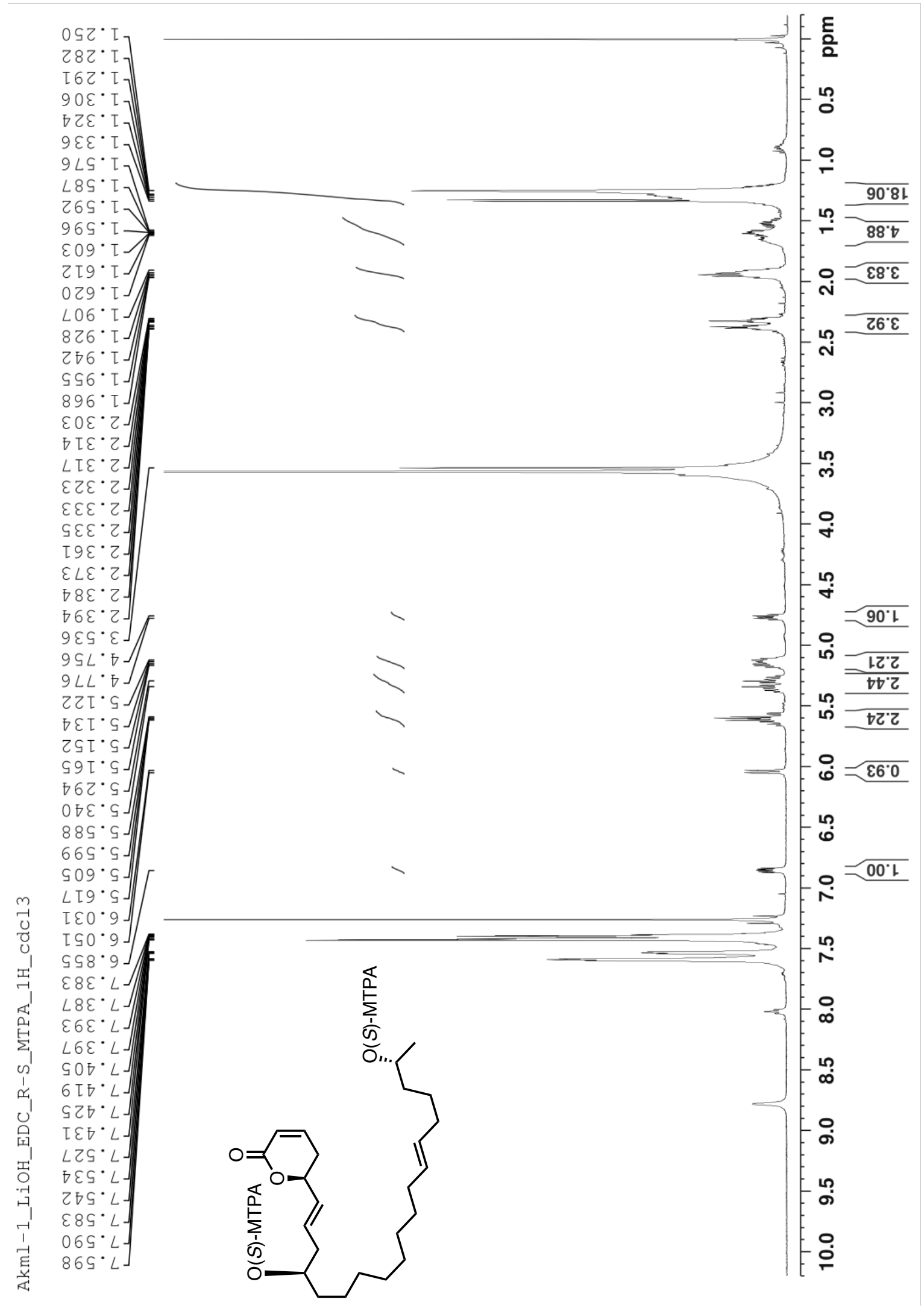


${ }^{1} \mathrm{H}$ NMR spectrum $\left(500 \mathrm{MHz}, \mathrm{CDCl}_{3}\right)$ of $\mathbf{1 1 b}$

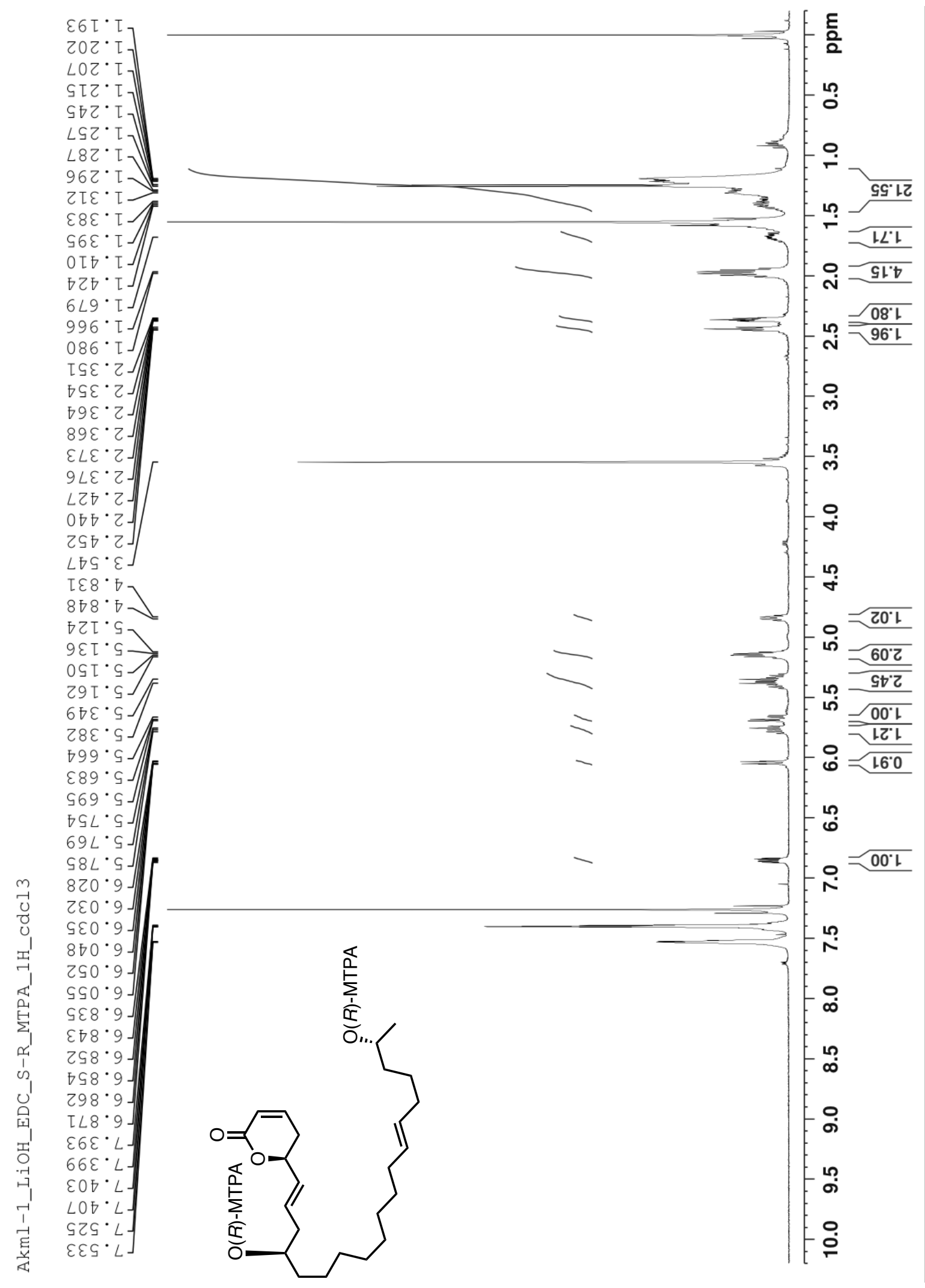


${ }^{1} \mathrm{H}$ NMR spectrum $\left(500 \mathrm{MHz}, \mathrm{CDCl}_{3}\right)$ of $\mathbf{1 3}$

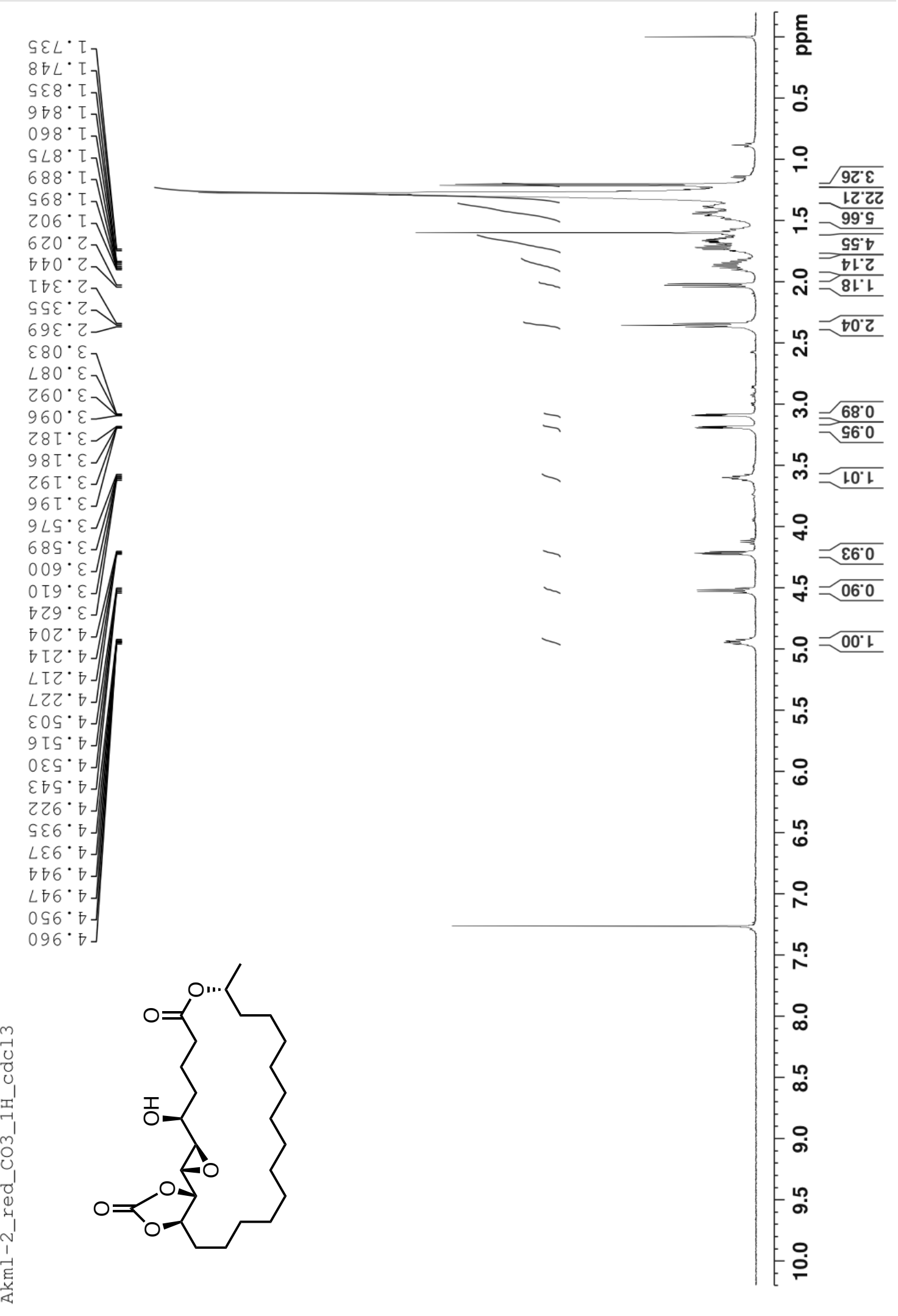


${ }^{13} \mathrm{C}$ NMR spectrum (125 MHz, $\left.\mathrm{CDCl}_{3}\right)$ of $\mathbf{1 3}$

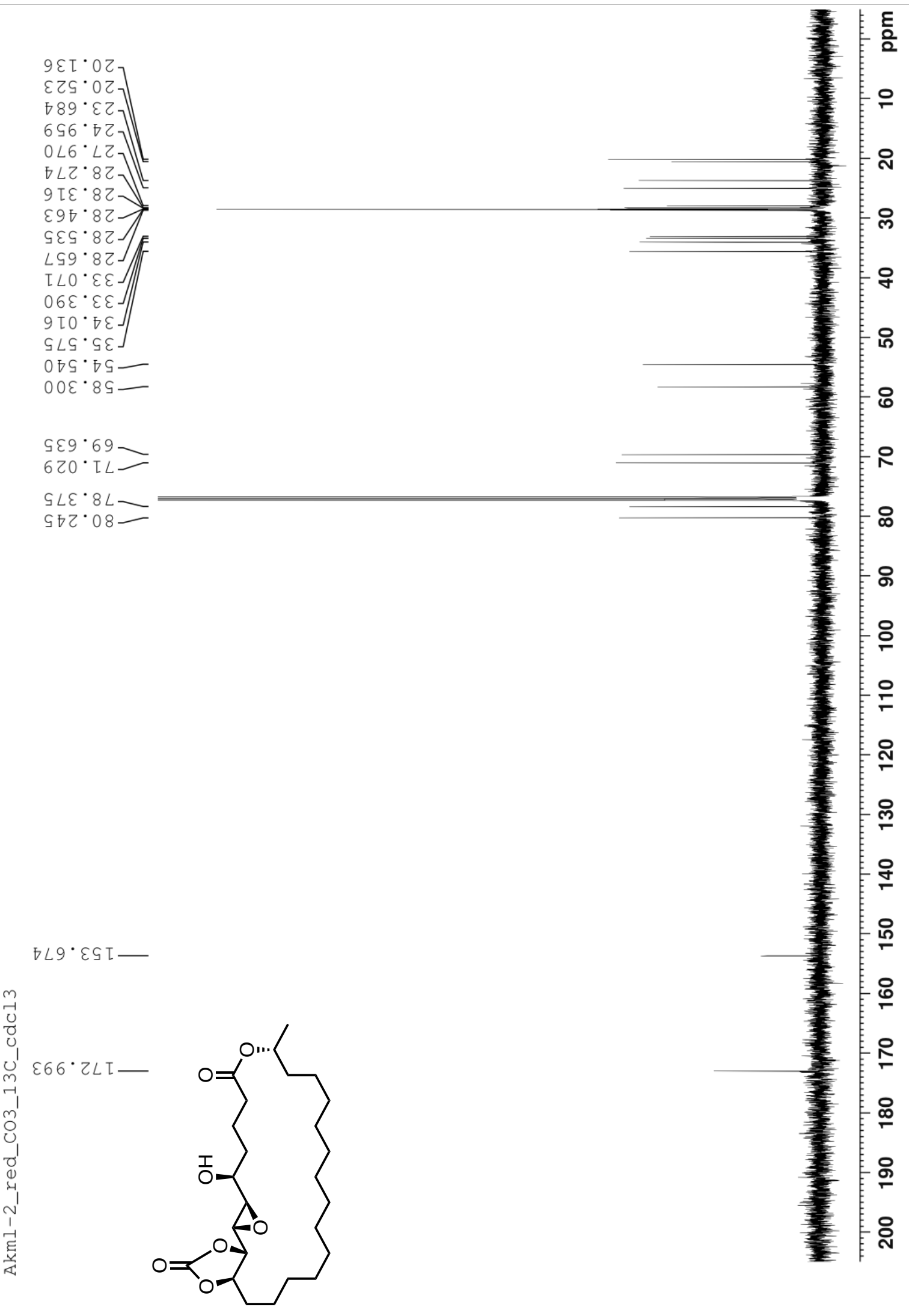


${ }^{1} \mathrm{H}-{ }^{1} \mathrm{H}$ COSY spectrum $\left(\mathrm{CDCl}_{3}\right)$ of $\mathbf{1 3}$

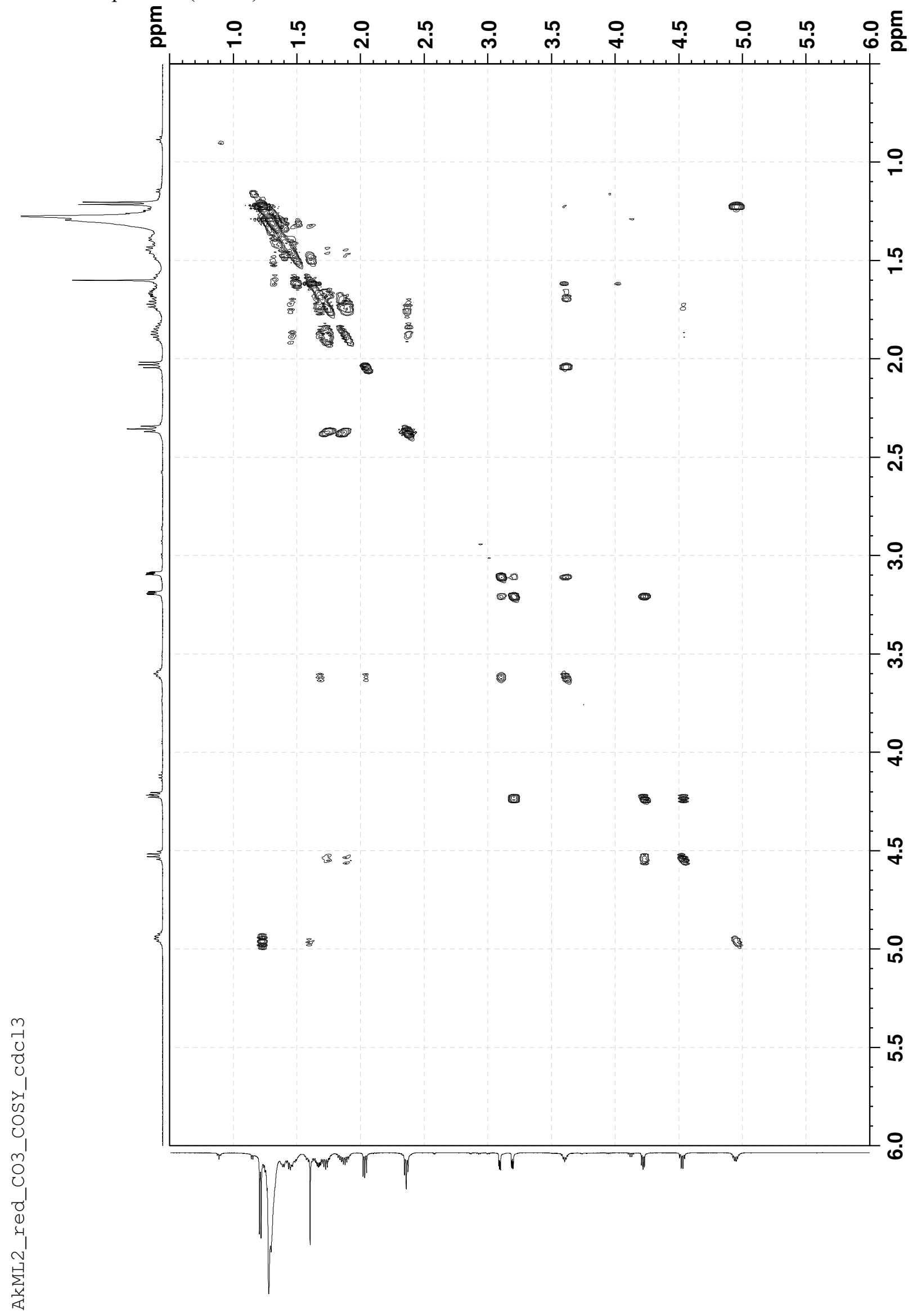


HSQC spectrum $\left(\mathrm{CDCl}_{3}\right)$ of $\mathbf{1 3}$

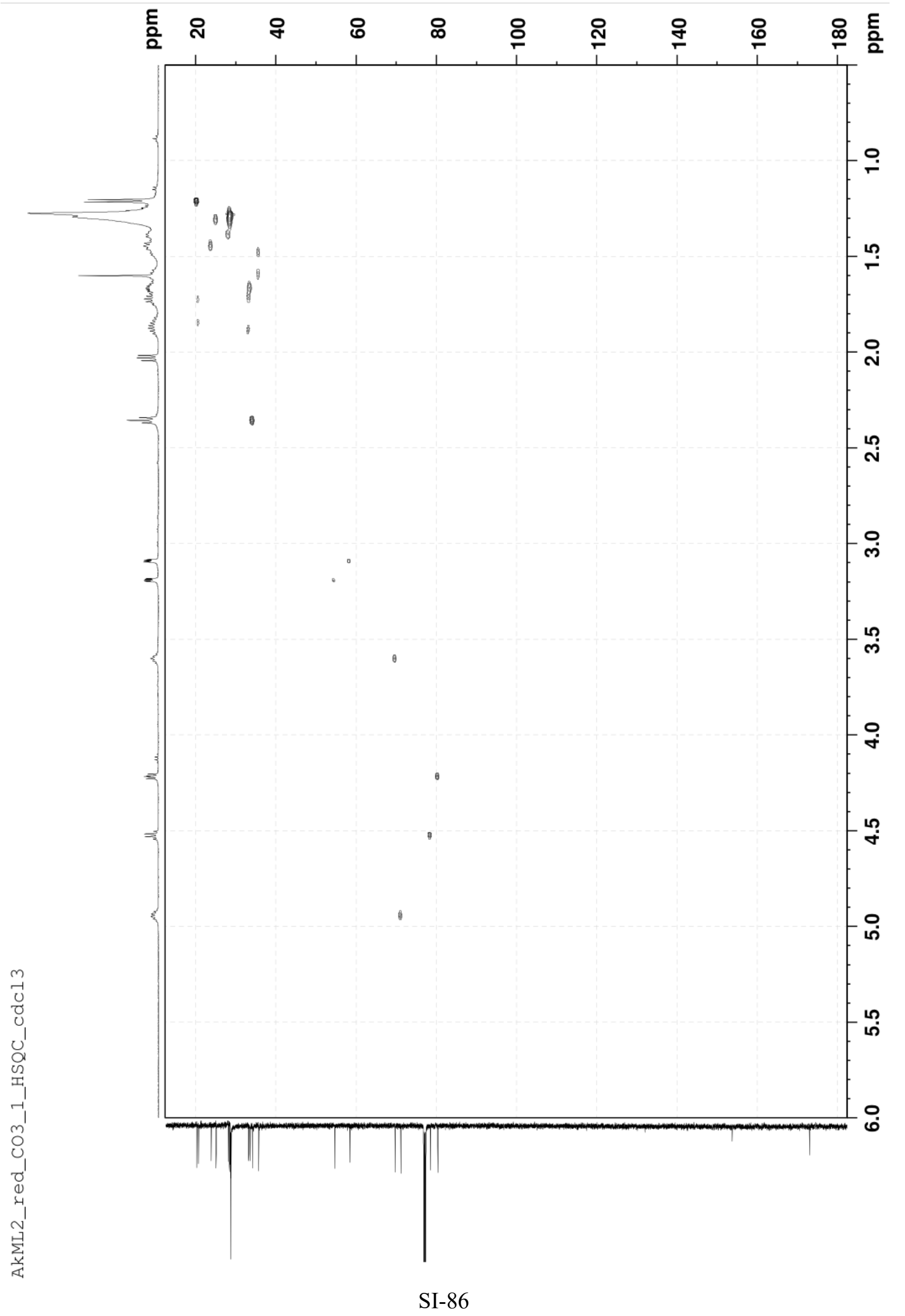


${ }^{1} \mathrm{H}$ NMR spectrum $\left(500 \mathrm{MHz}, \mathrm{CDCl}_{3}\right)$ of $\mathbf{1 4 a}$

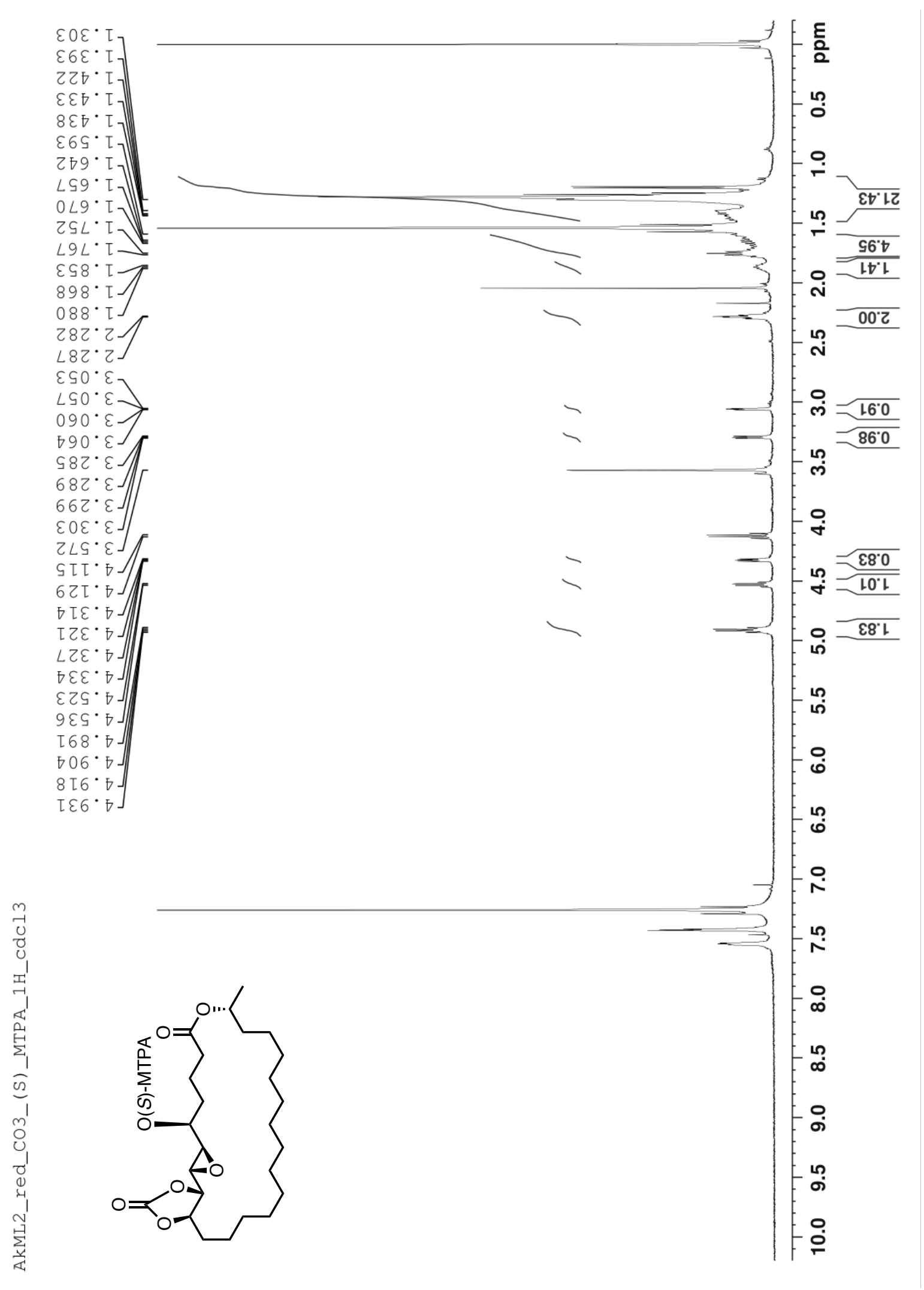


${ }^{1} \mathrm{H}$ NMR spectrum $\left(500 \mathrm{MHz}, \mathrm{CDCl}_{3}\right)$ of $\mathbf{1 4 b}$

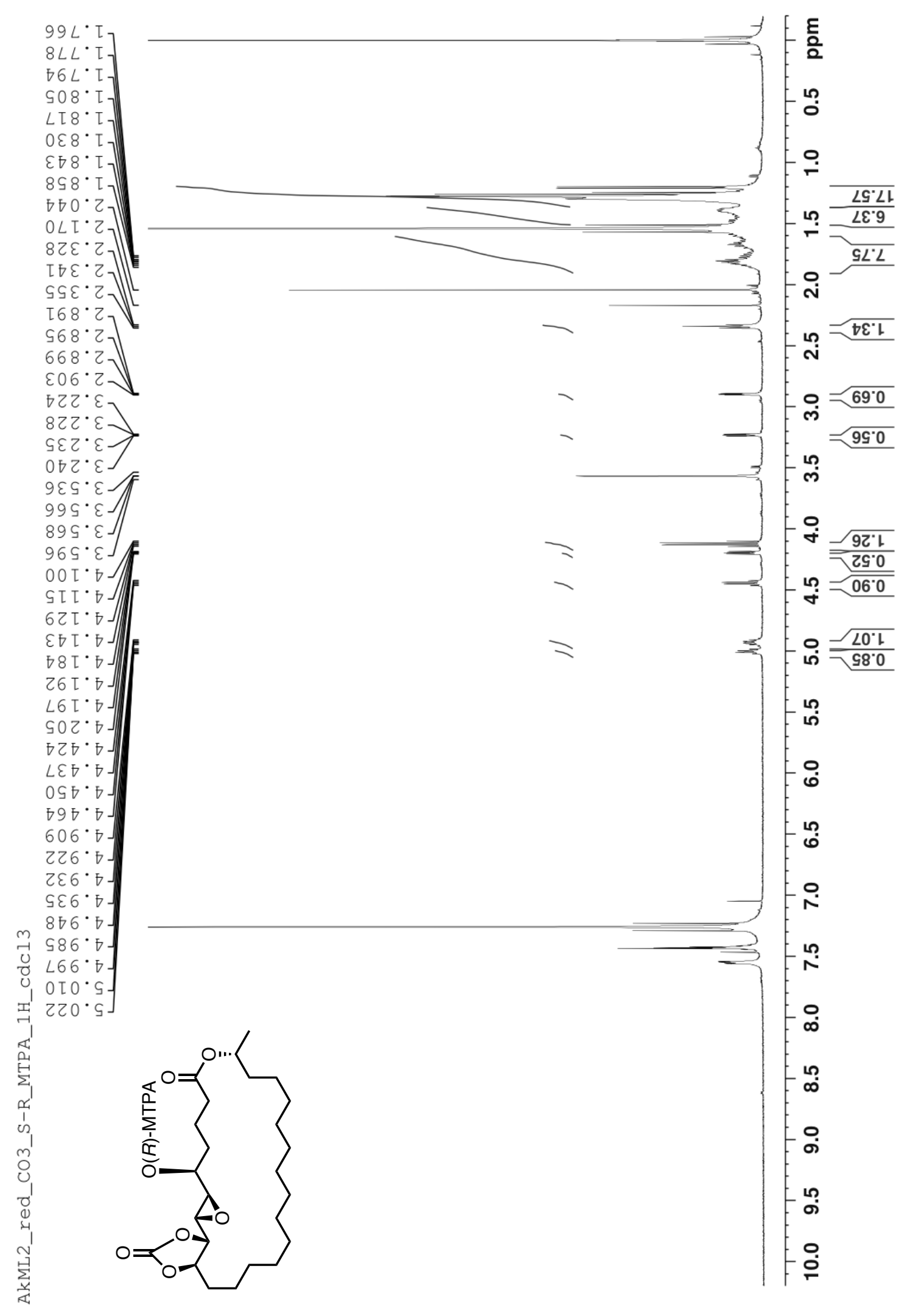


${ }^{1} \mathrm{H}$ NMR spectrum $\left(500 \mathrm{MHz}, \mathrm{C}_{6} \mathrm{D}_{6}\right)$ of $\mathbf{1 5}$

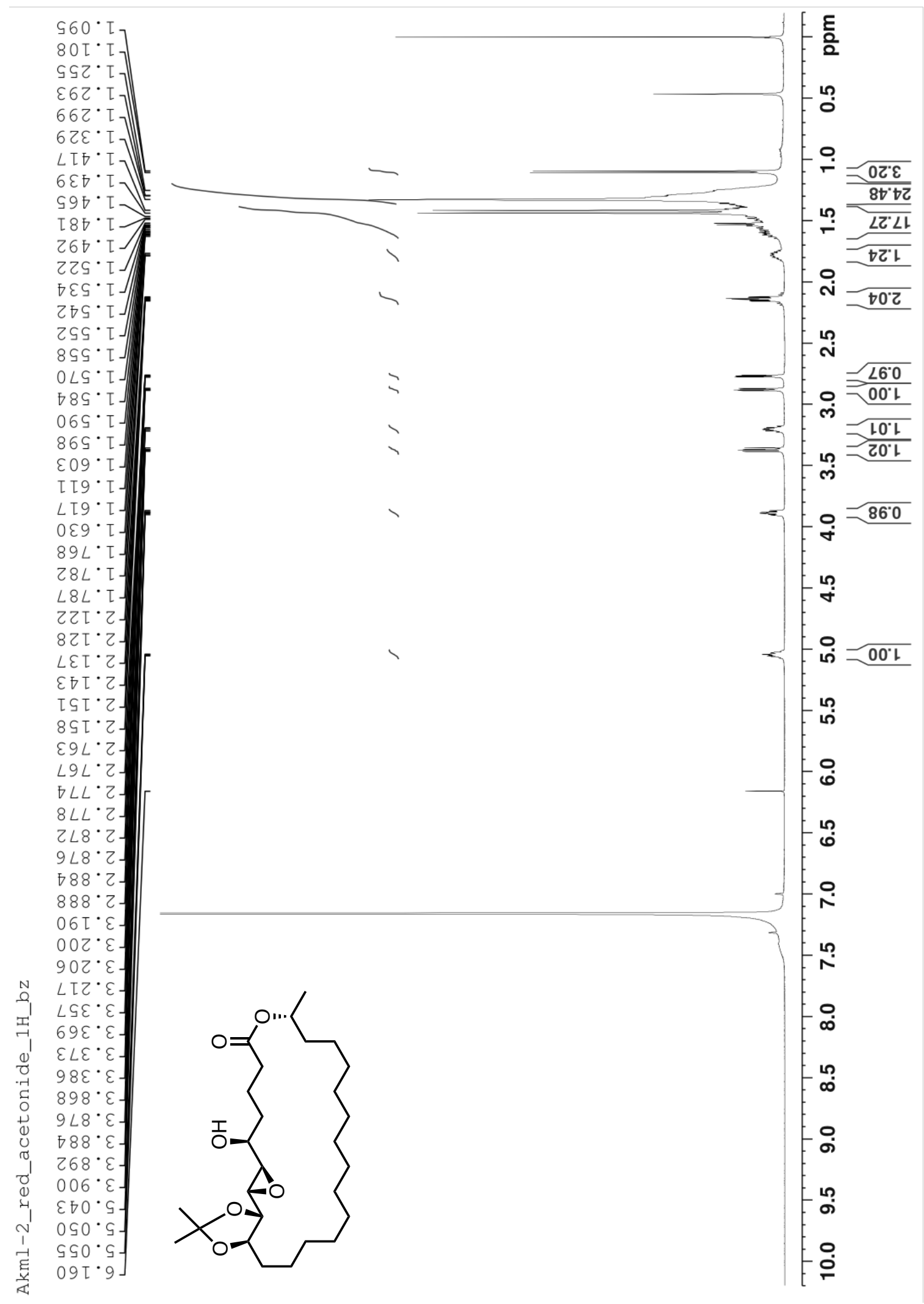


${ }^{13} \mathrm{C}$ NMR spectrum (125 MHz, $\left.\mathrm{C}_{6} \mathrm{D}_{6}\right)$ of $\mathbf{1 5}$

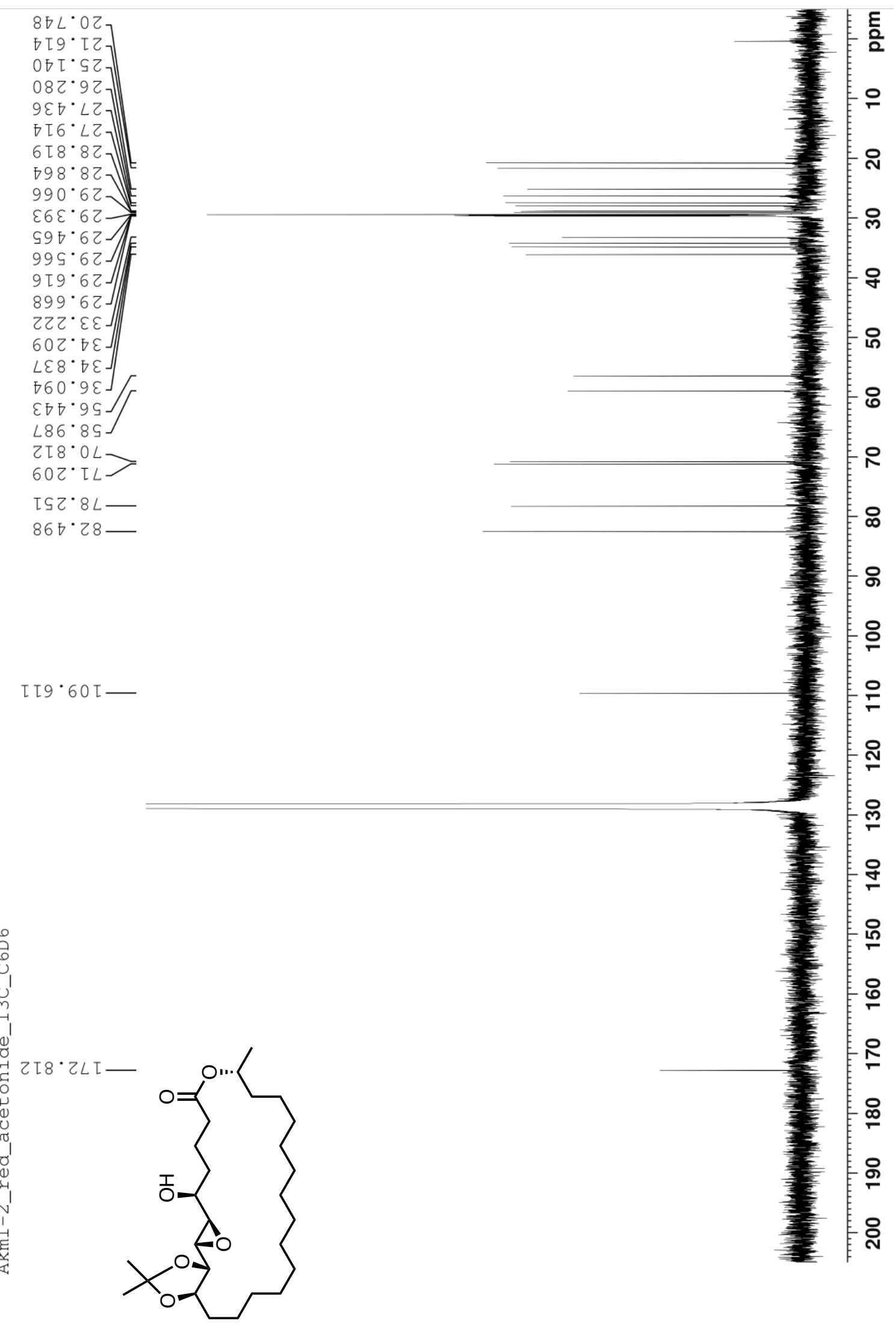


${ }^{1} \mathrm{H}-{ }^{1} \mathrm{H}$ COSY spectrum $\left(\mathrm{C}_{6} \mathrm{D}_{6}\right)$ of $\mathbf{1 5}$

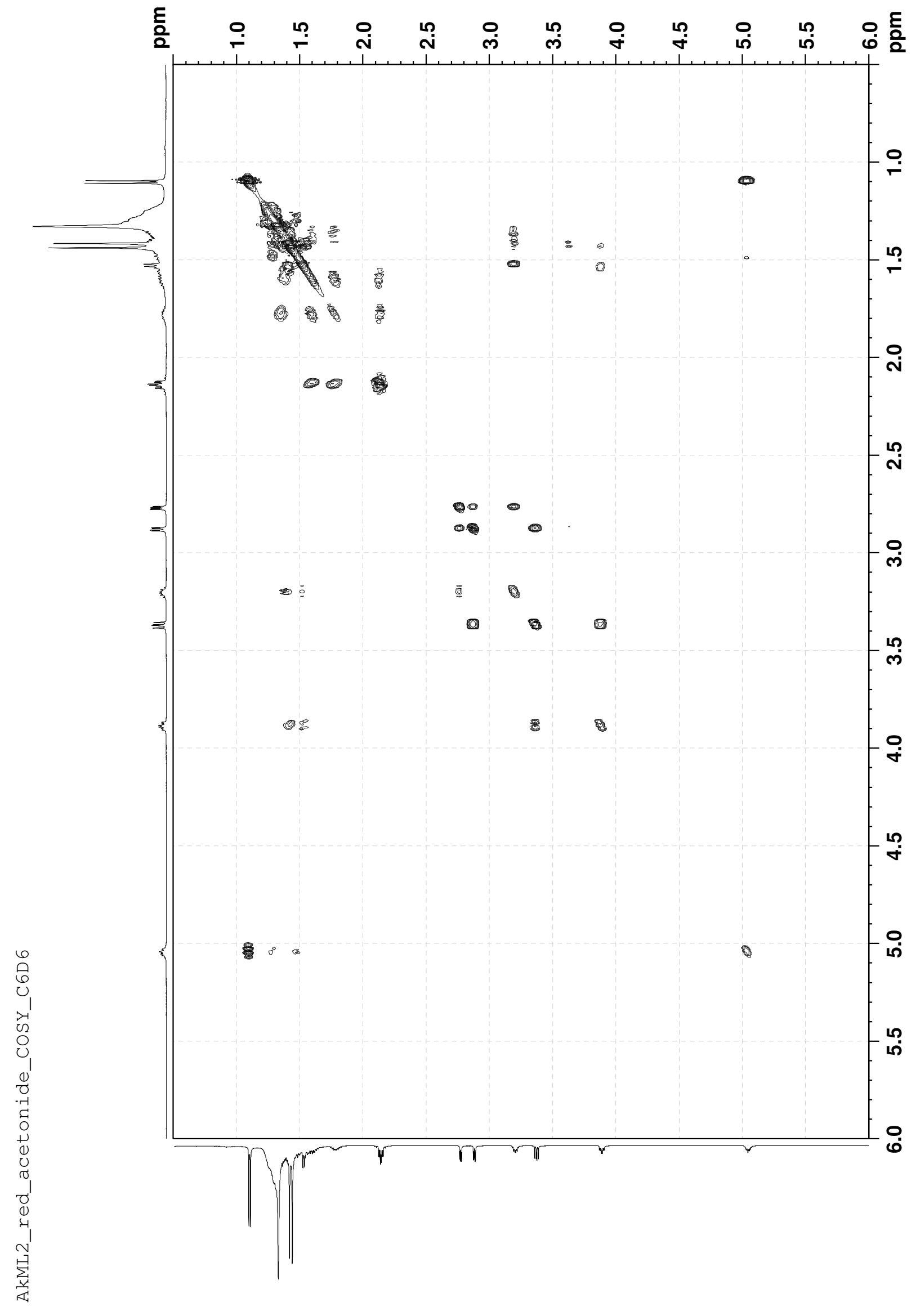


HMBC spectrum $\left(\mathrm{C}_{6} \mathrm{D}_{6}\right)$ of $\mathbf{1 5}$

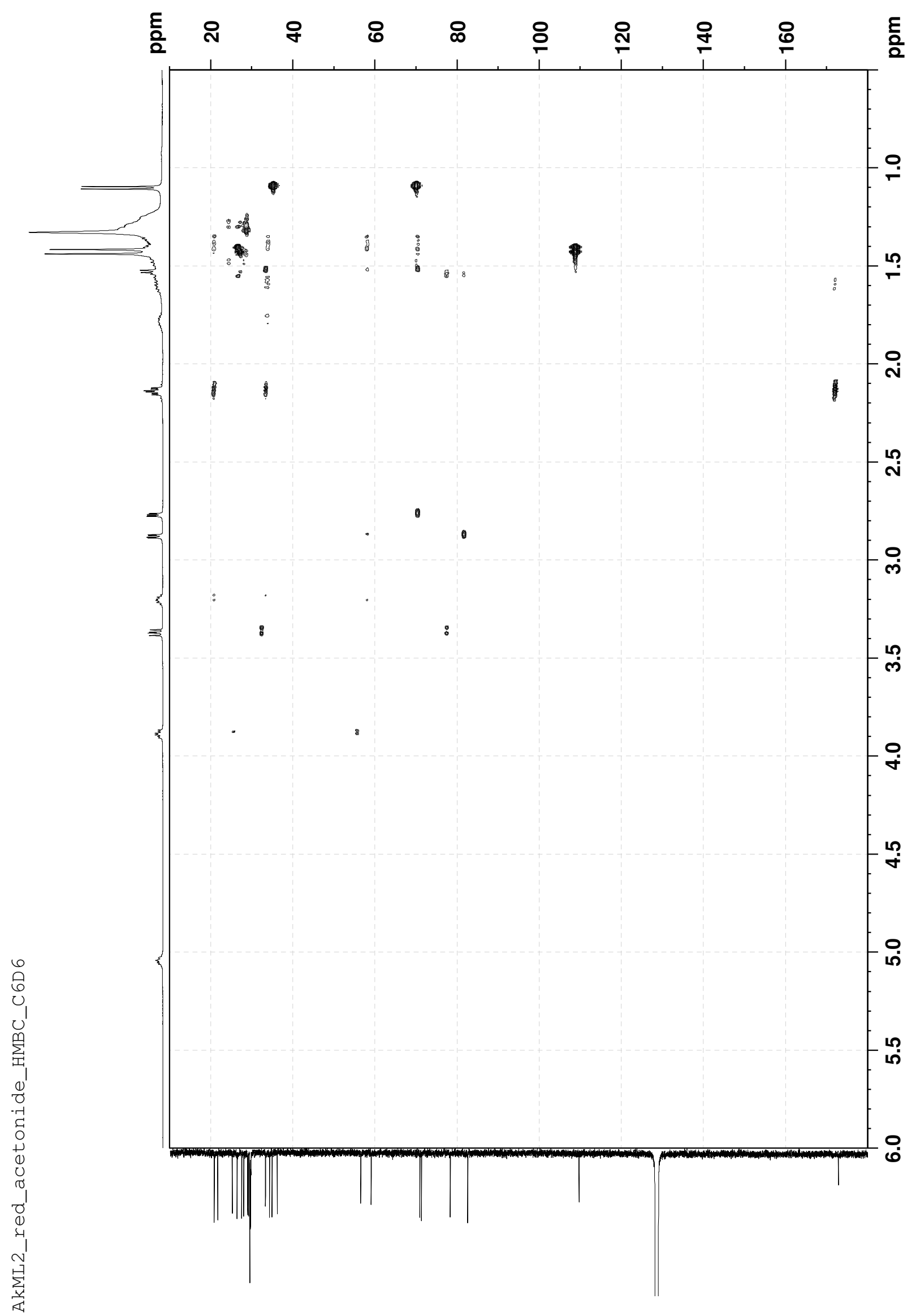


HSQC spectrum $\left(\mathrm{C}_{6} \mathrm{D}_{6}\right)$ of $\mathbf{1 5}$

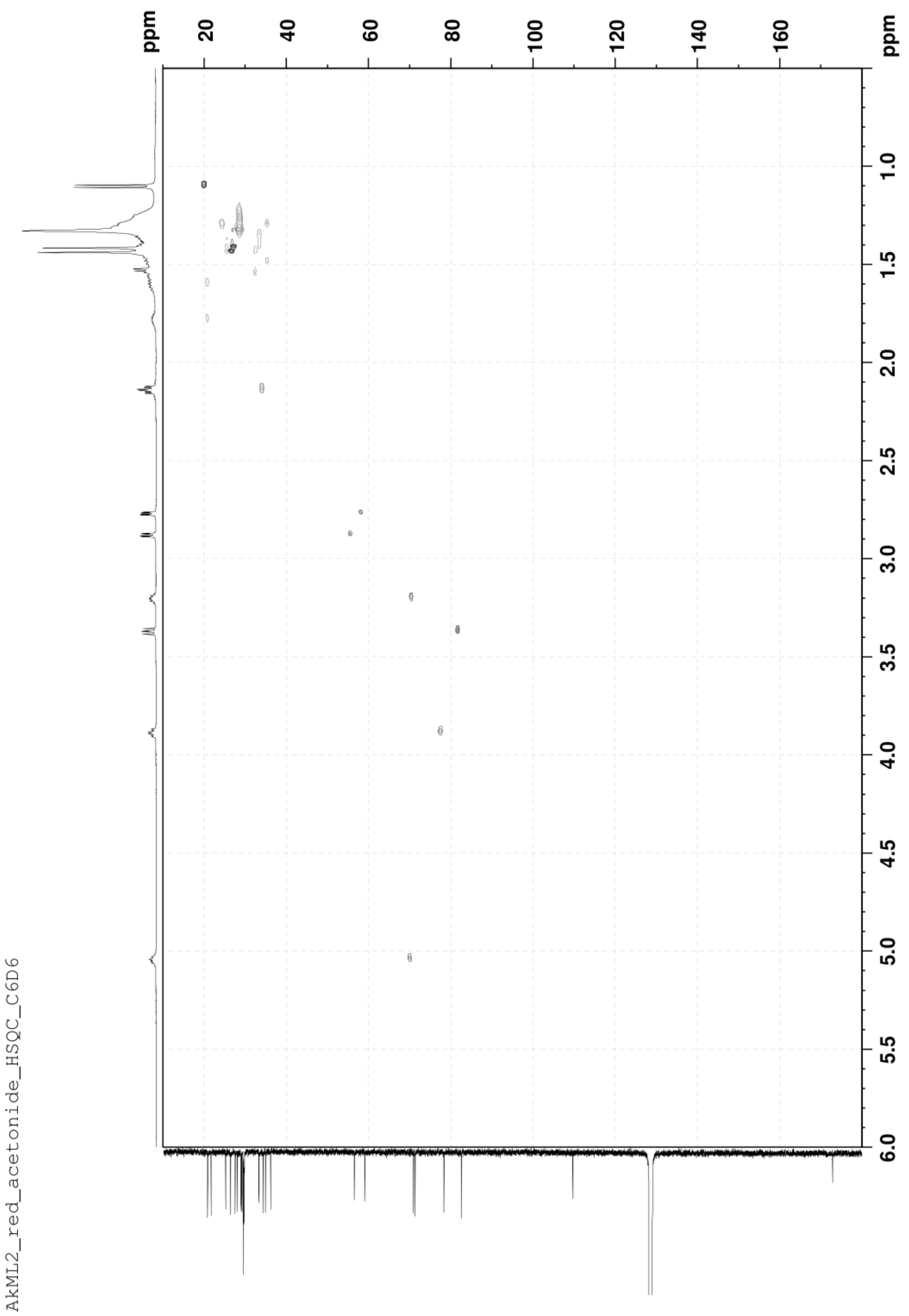


NOESY spectrum $\left(\mathrm{C}_{6} \mathrm{D}_{6}\right)$ of $\mathbf{1 5}$

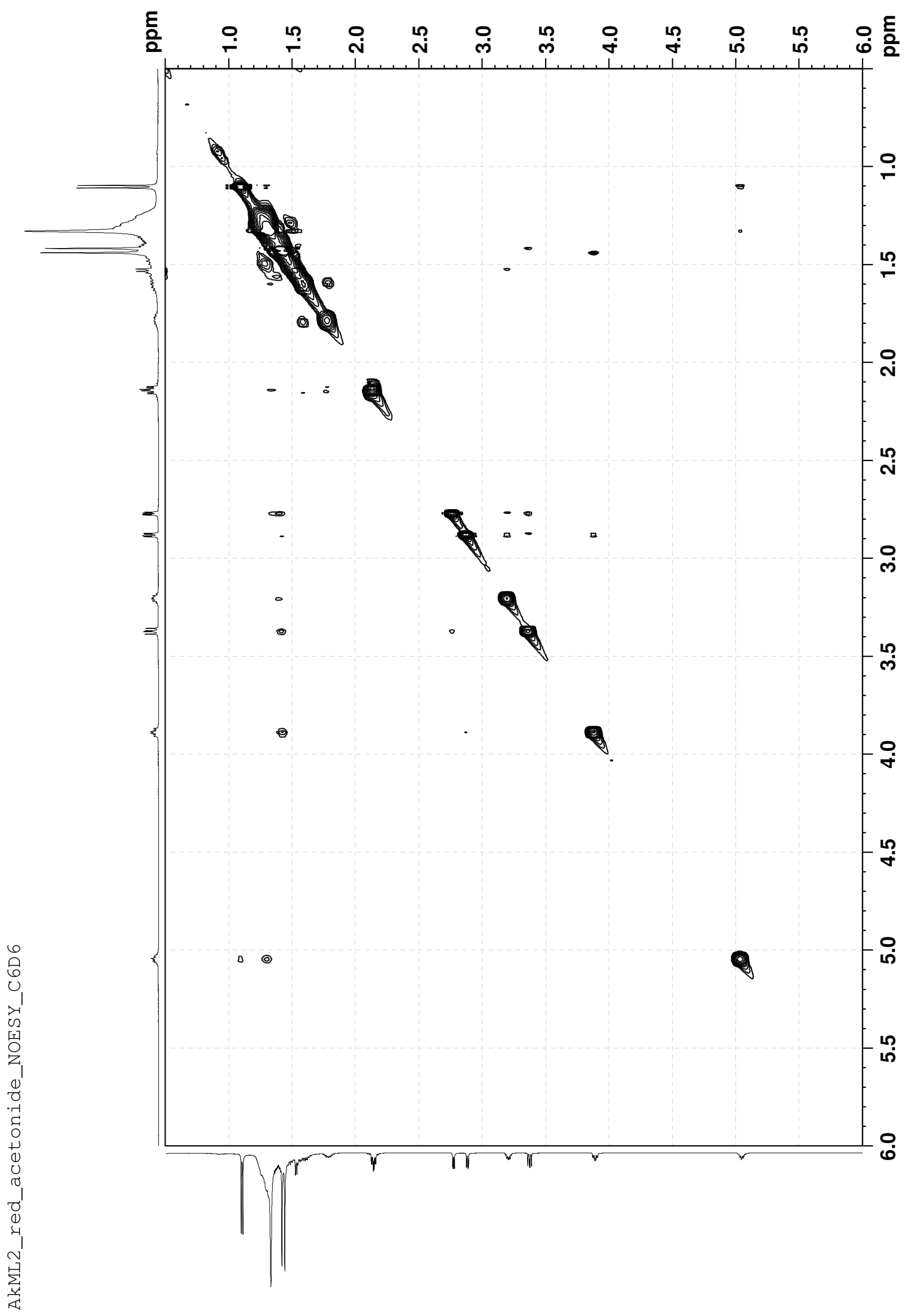


NOESY spectrum (exp) $\left(\mathrm{C}_{6} \mathrm{D}_{6}\right)$ of $\mathbf{1 5}$

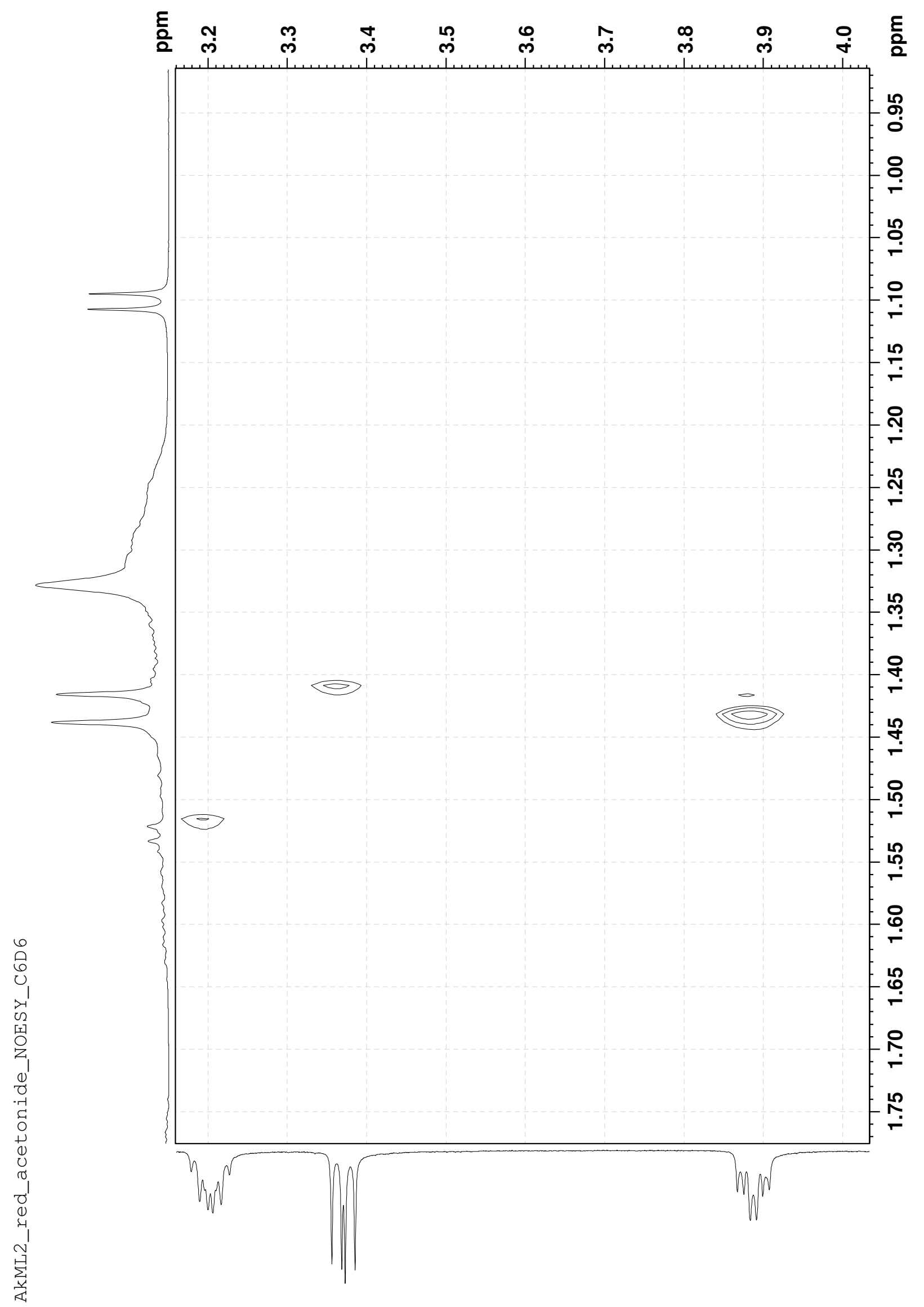


${ }^{1} \mathrm{H}$ NMR spectrum $\left(500 \mathrm{MHz}, \mathrm{CDCl}_{3}\right.$ ) of $\mathbf{1 7}$

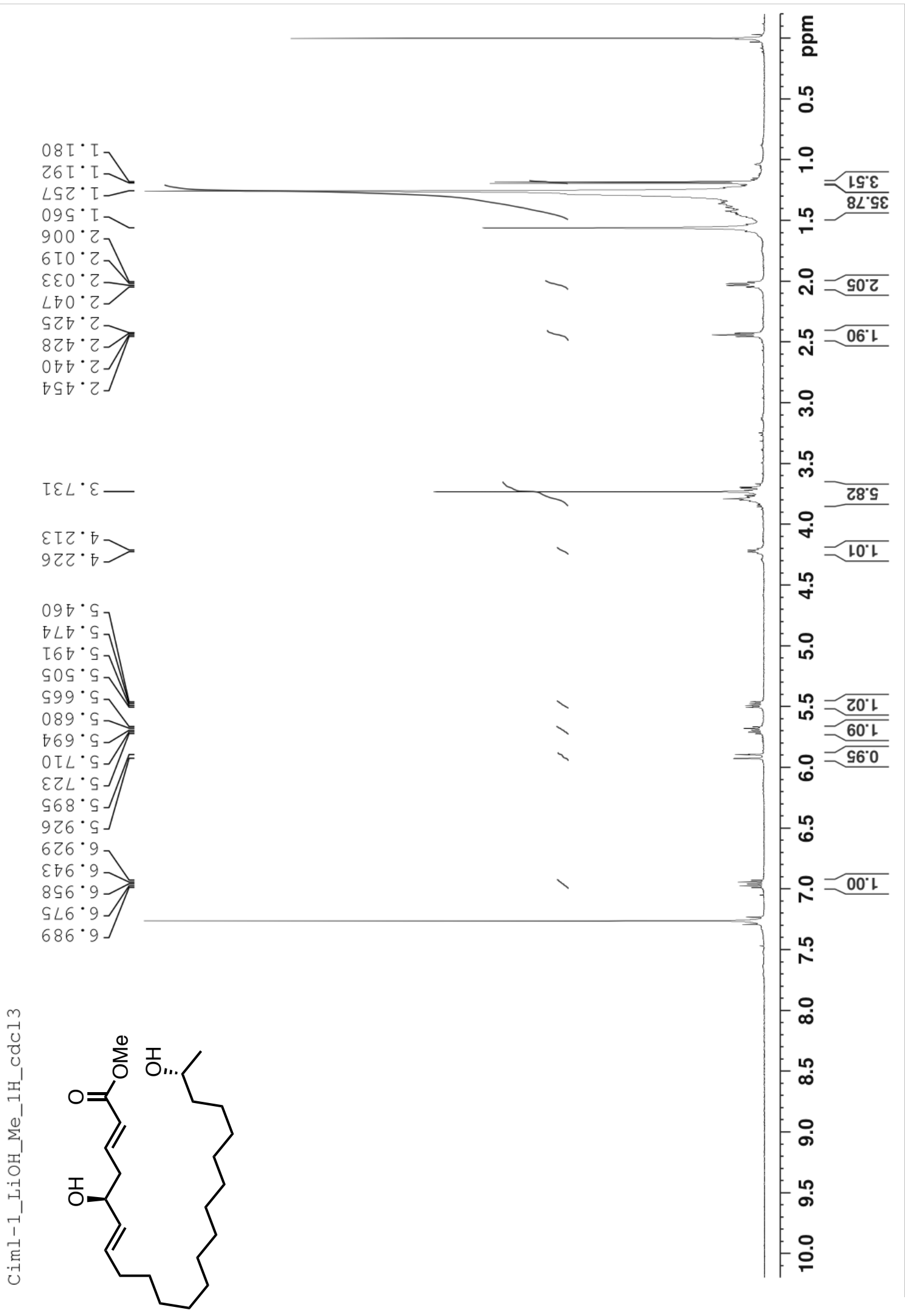


${ }^{13} \mathrm{C}$ NMR spectrum $\left(\mathrm{CDCl}_{3}\right)$ of $\mathbf{1 7}$

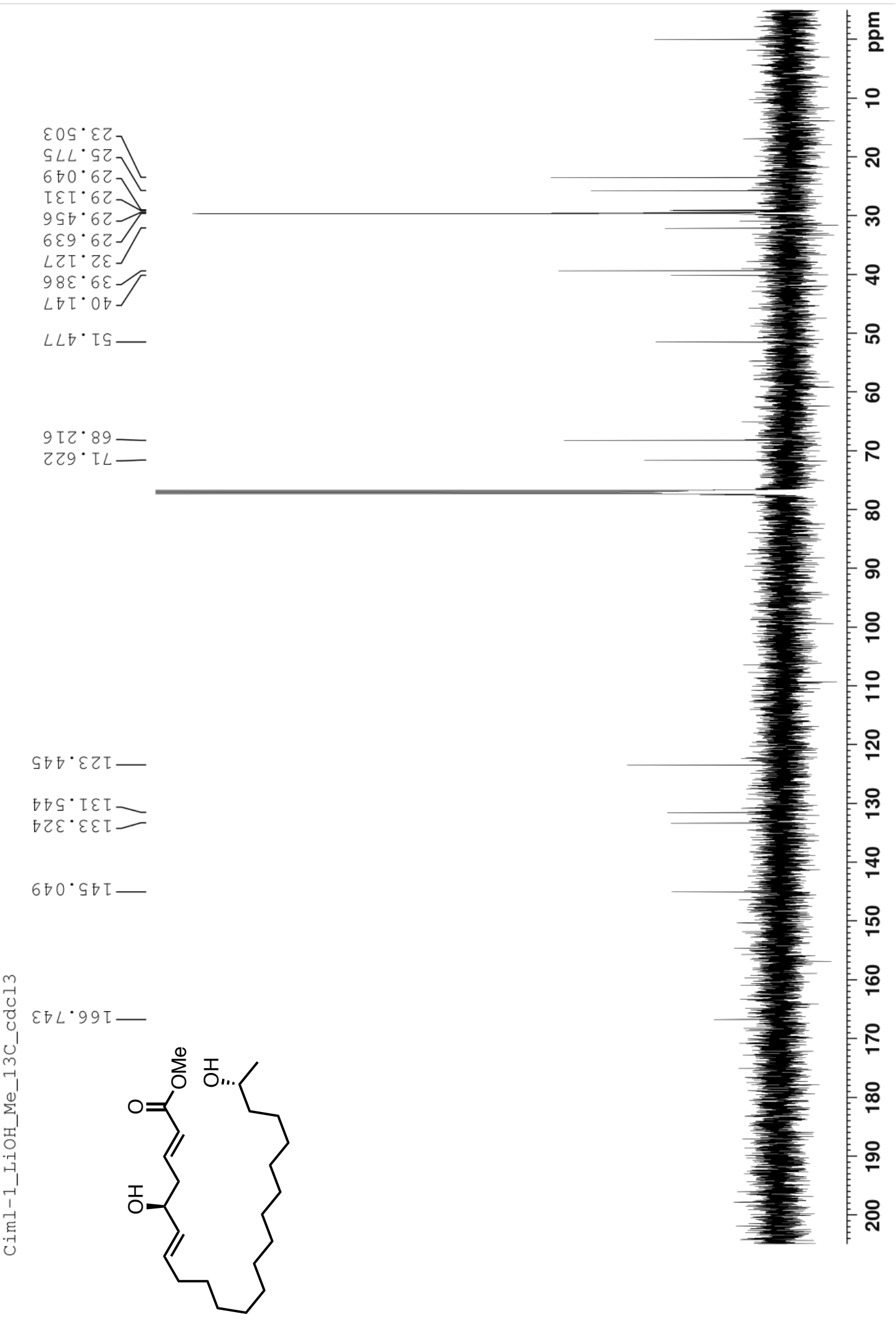


${ }^{1} \mathrm{H}-{ }^{1} \mathrm{H}$ COSY spectrum $\left(\mathrm{CDCl}_{3}\right)$ of $\mathbf{1 7}$

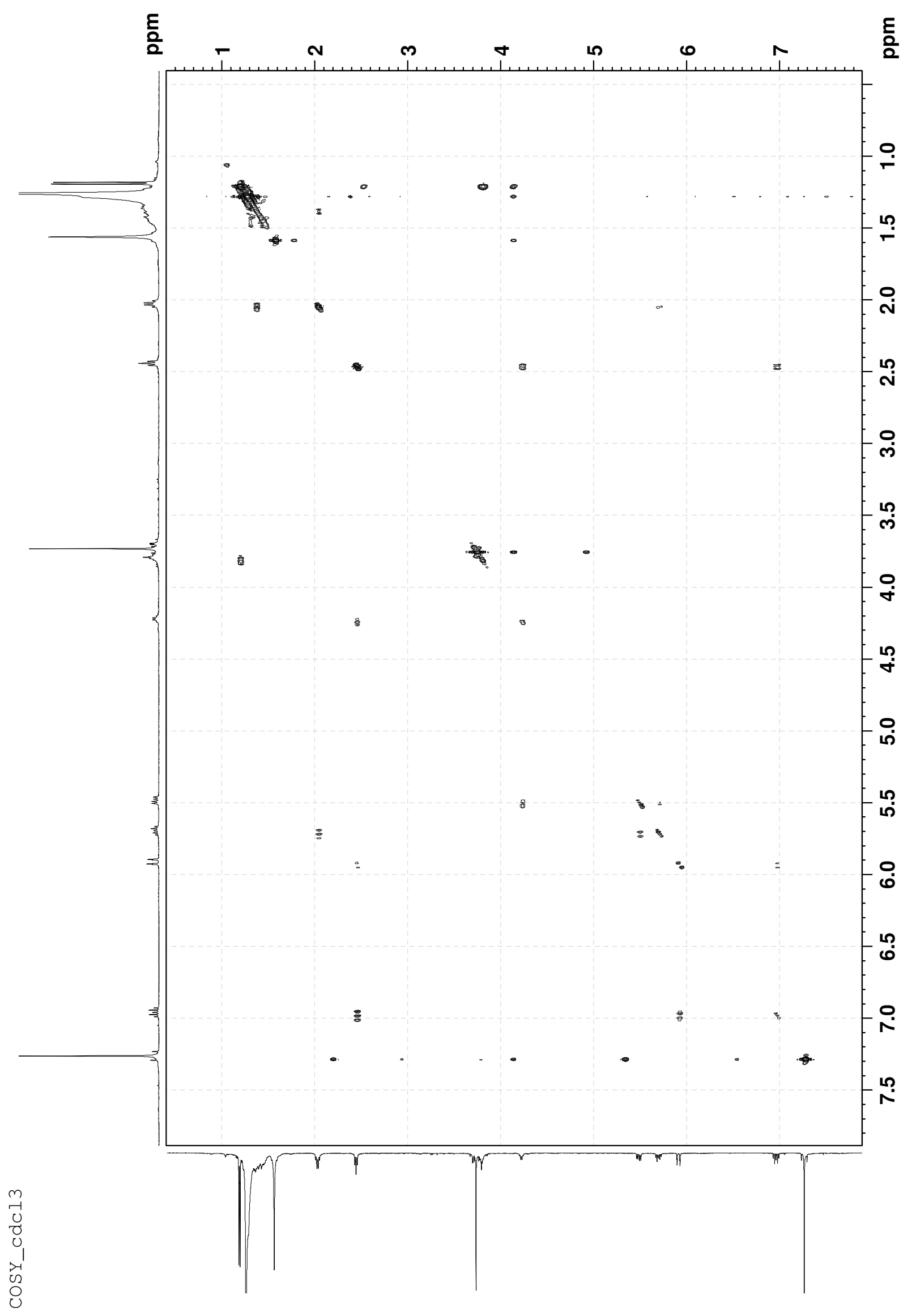


HMBC spectrum $\left(\mathrm{CDCl}_{3}\right)$ of $\mathbf{1 7}$

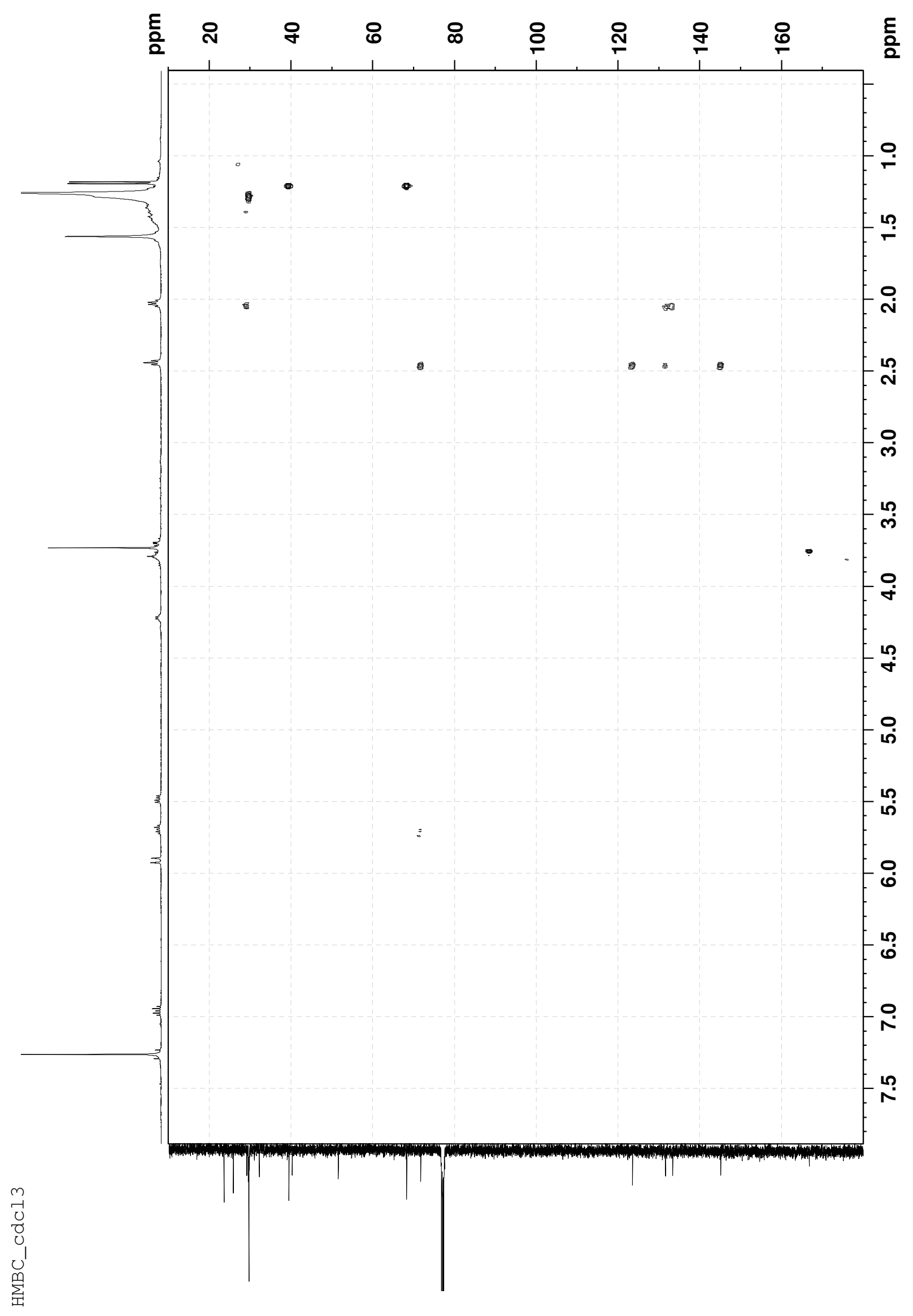


HSQC spectrum $\left(\mathrm{CDCl}_{3}\right)$ of $\mathbf{1 7}$

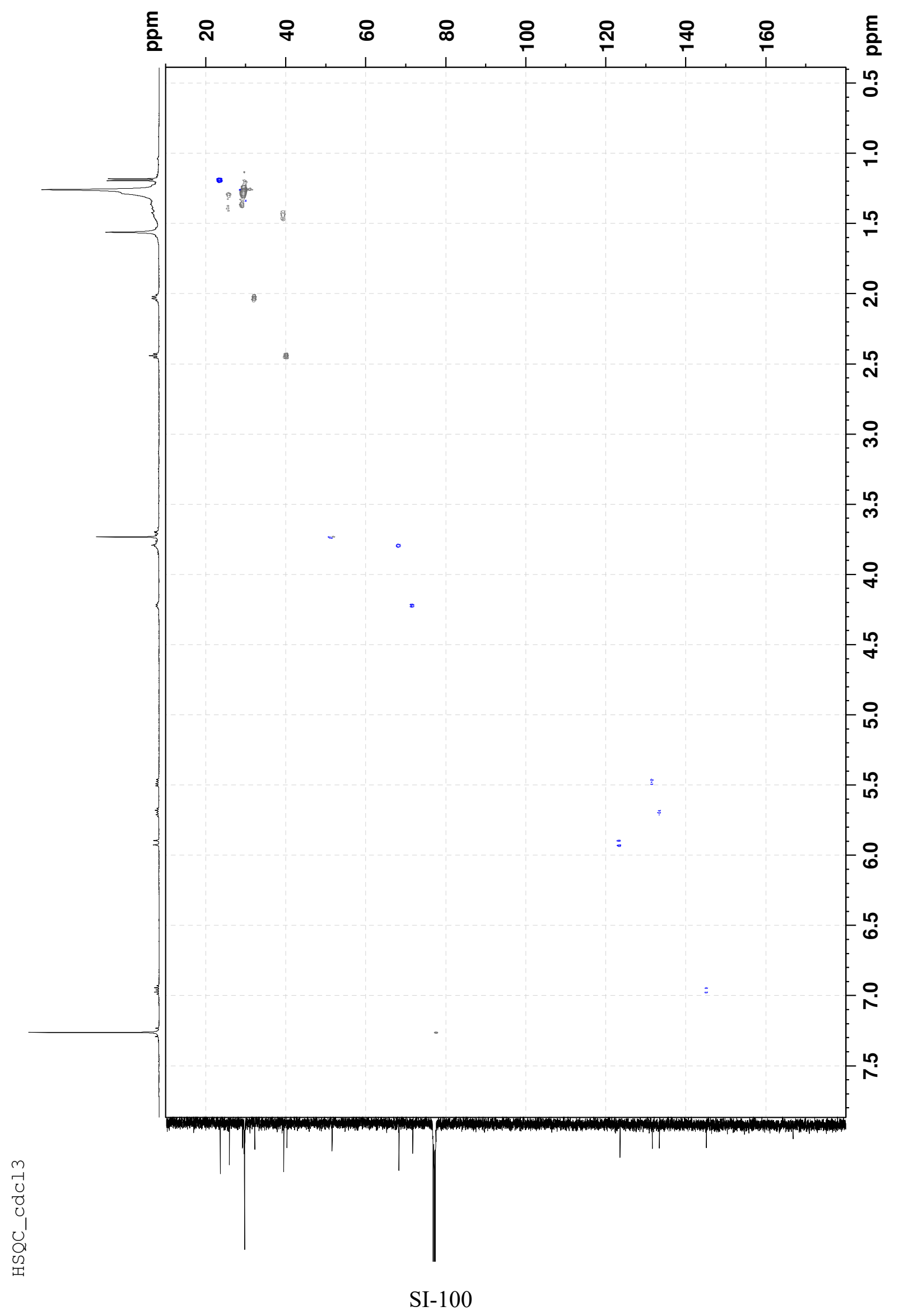


${ }^{1} \mathrm{H}$ NMR spectrum $\left(500 \mathrm{MHz}, \mathrm{CDCl}_{3}\right)$ of $\mathbf{1 8 a}$

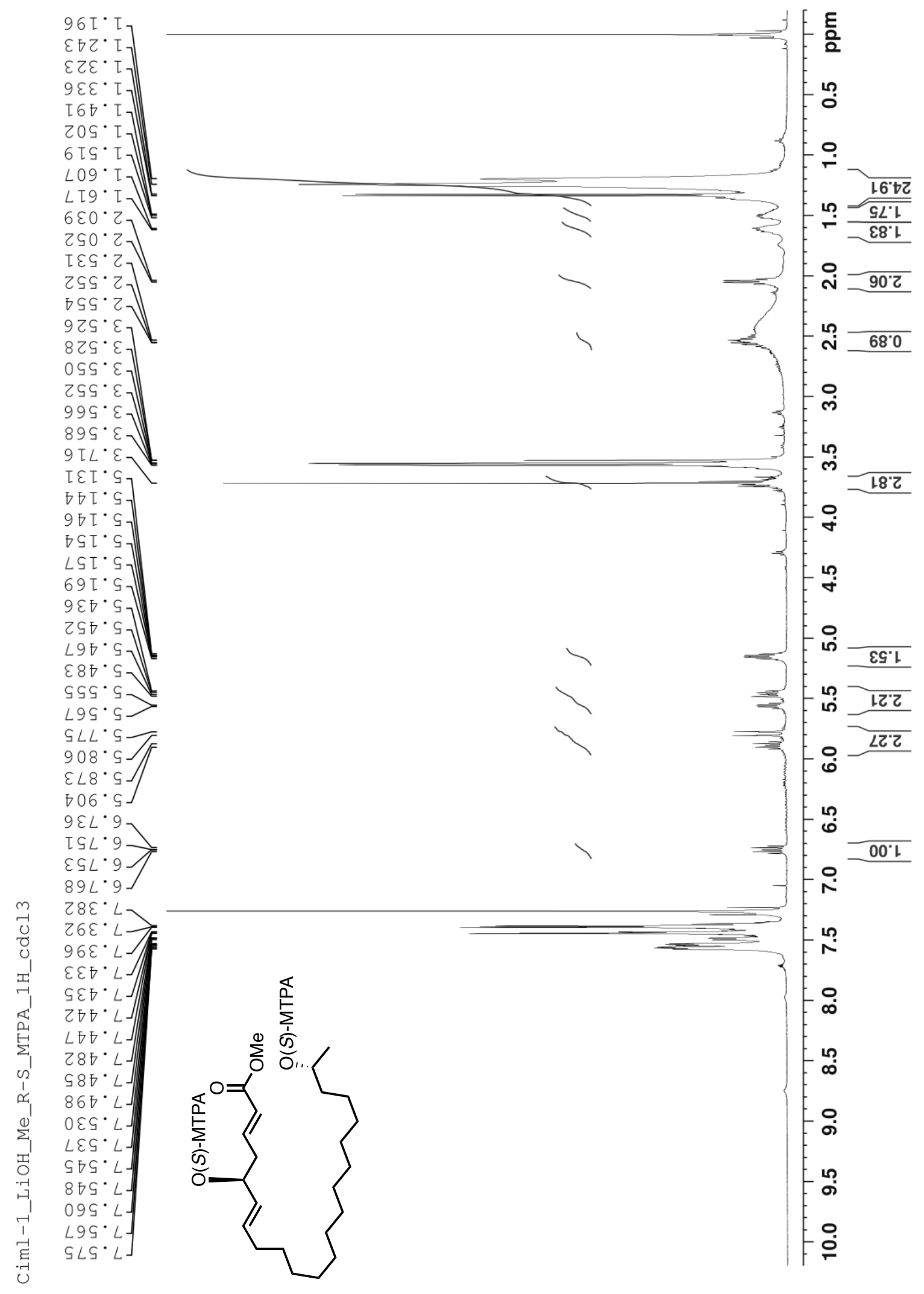


${ }^{1} \mathrm{H}$ NMR spectrum $\left(500 \mathrm{MHz}, \mathrm{CDCl}_{3}\right)$ of $\mathbf{1 8 b}$

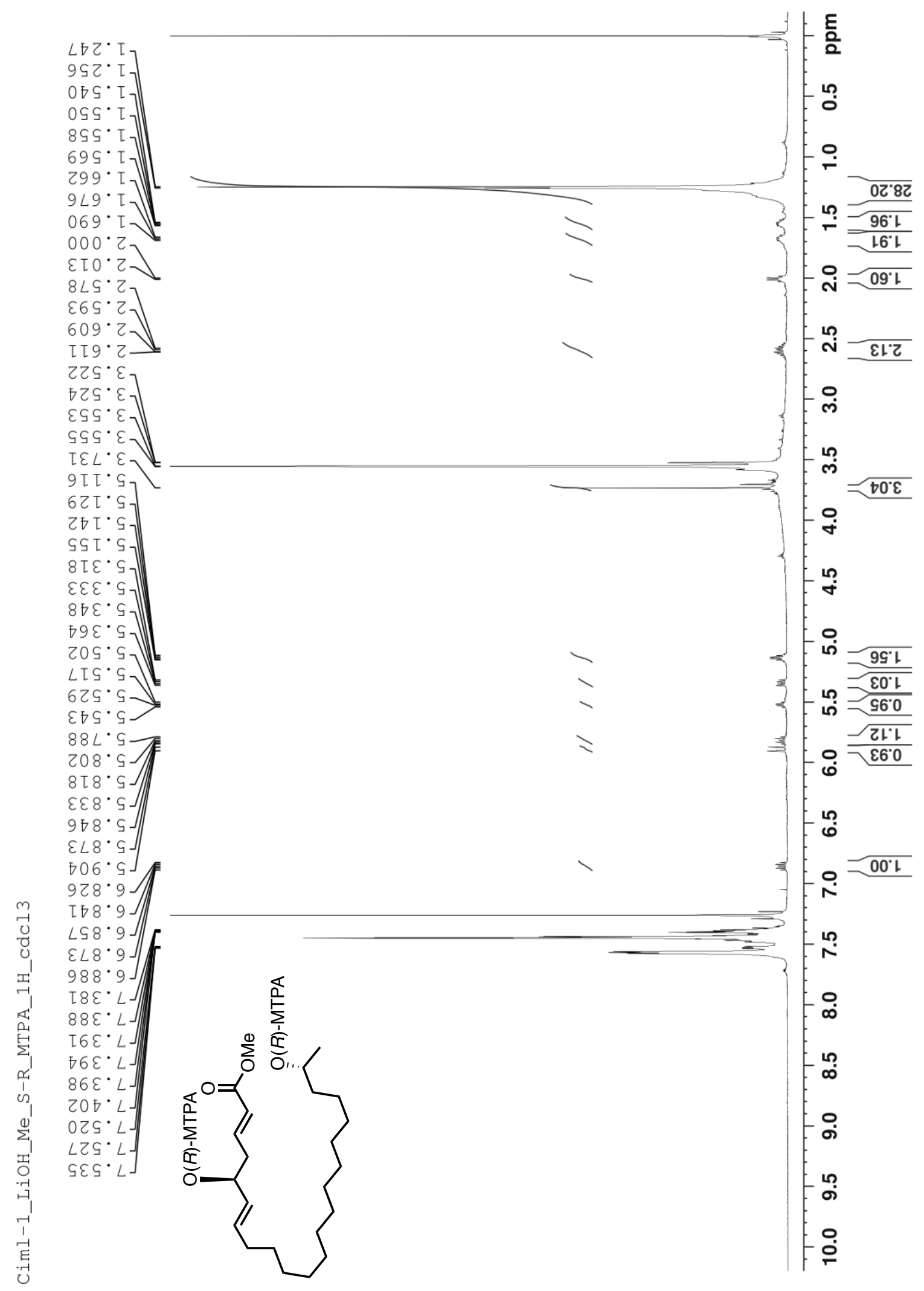


${ }^{1} \mathrm{H}$ NMR spectrum $\left(500 \mathrm{MHz}, \mathrm{CDCl}_{3}\right)$ of $\mathbf{1 9 a}$

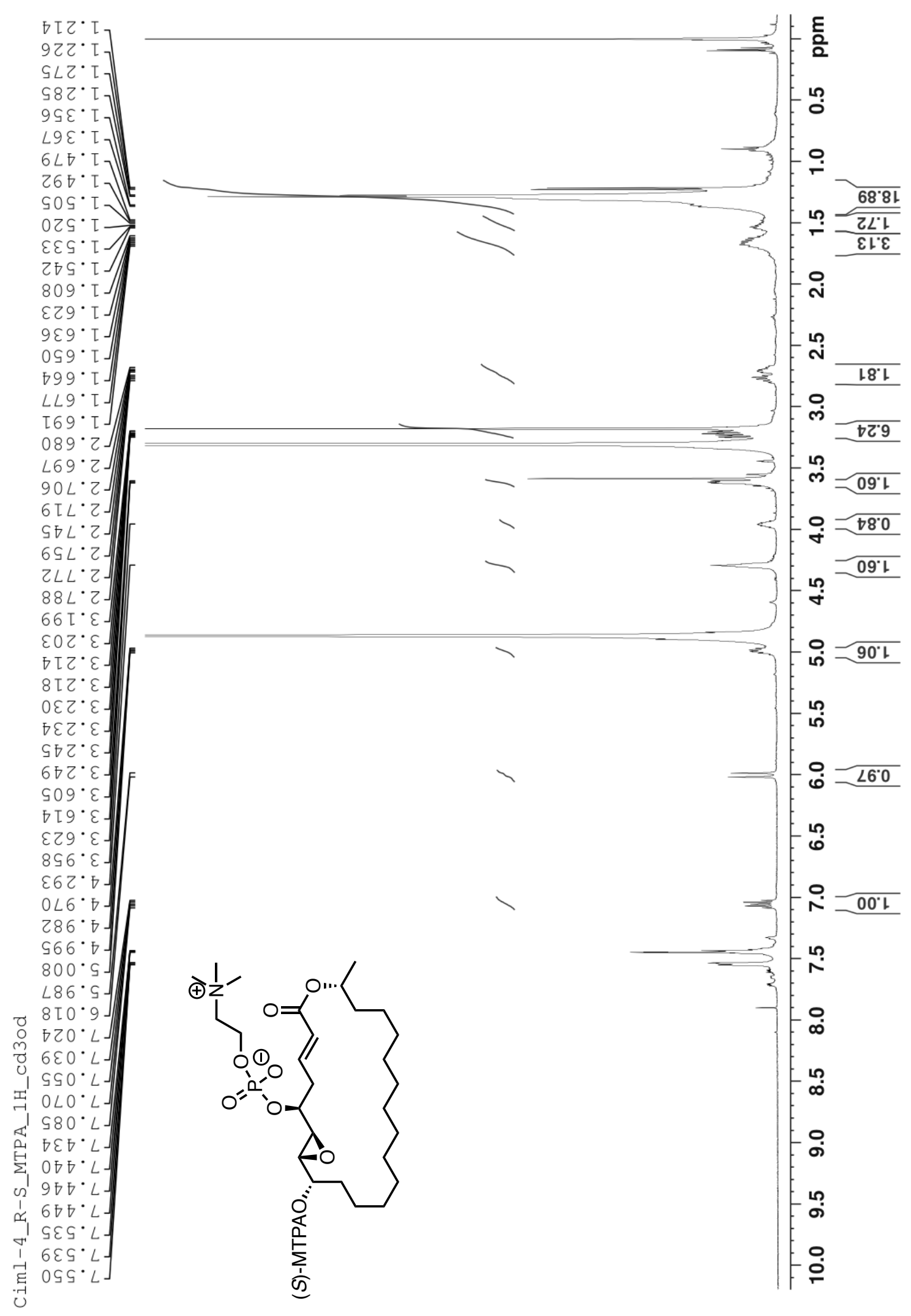


${ }^{1} \mathrm{H}$ NMR spectrum $\left(500 \mathrm{MHz}, \mathrm{CDCl}_{3}\right)$ of $\mathbf{1 9 b}$

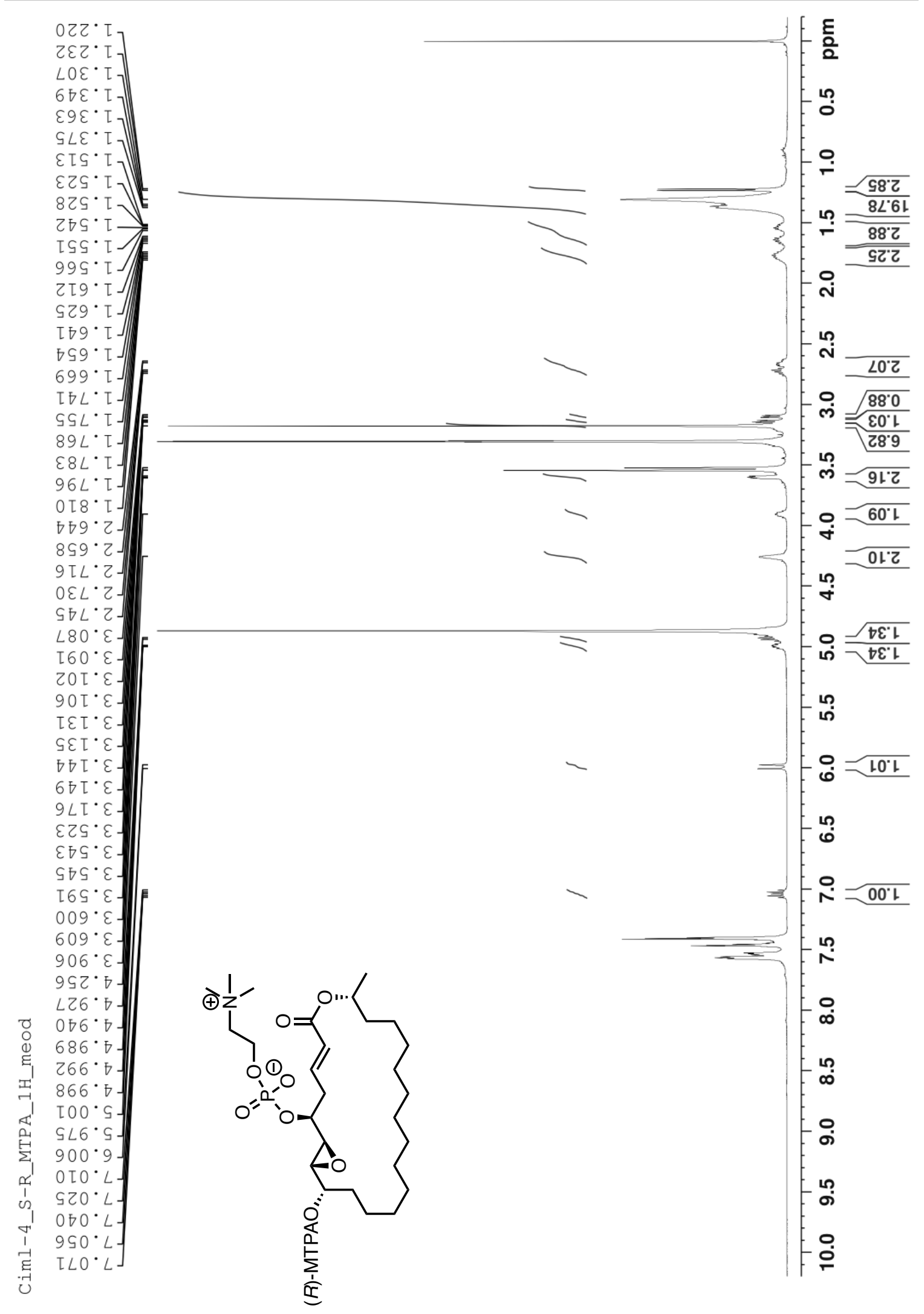

